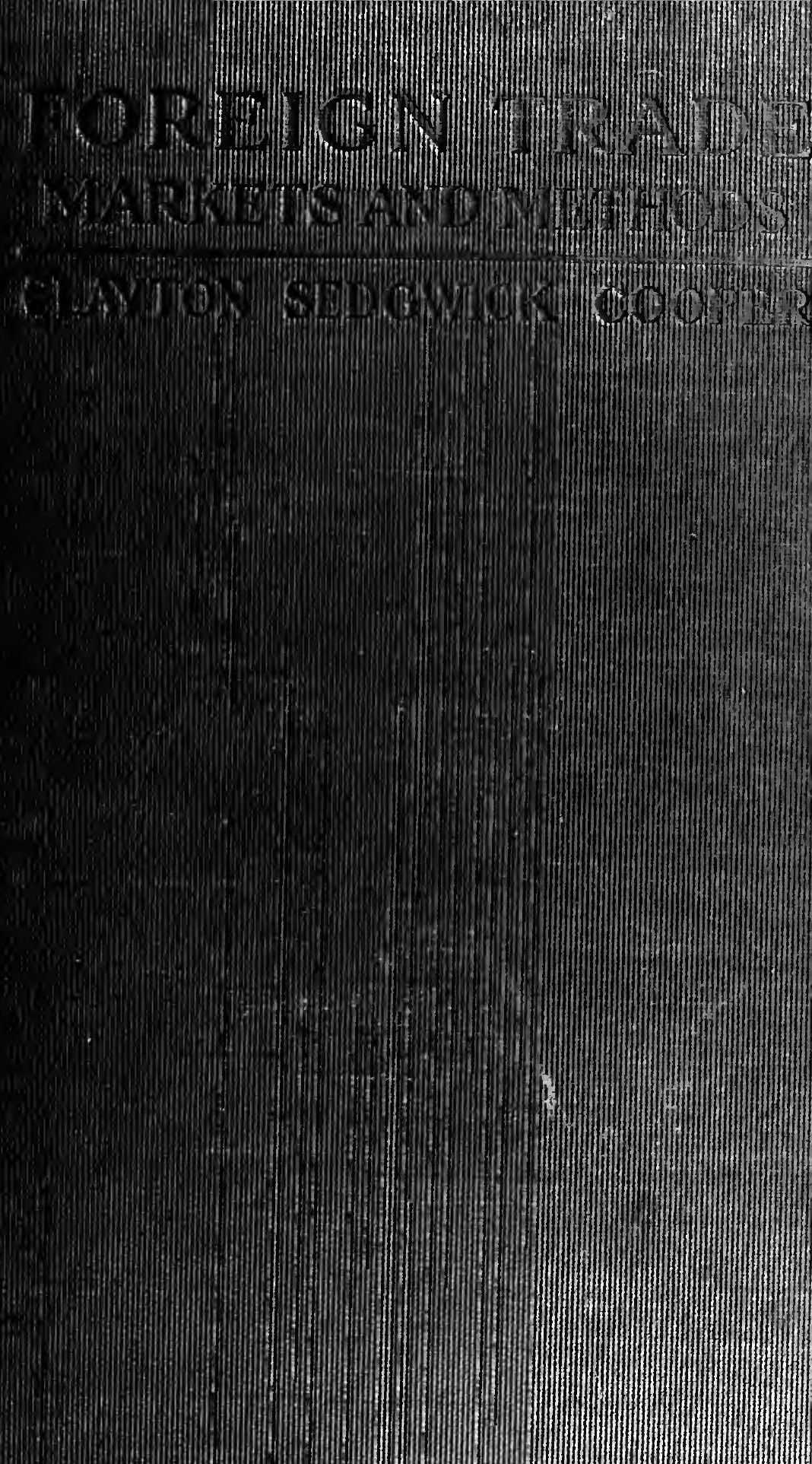





\section{FOREIGN TRADE MARKETS AND METHODS}

BY

\section{CLAYTON SEDGWICK COOPER}

AUTHOR OF " UNDERSTANDING SOUTH AMERICA,"

“THE BRAZILIANS AND THEIR COUNTRY," ETC.

D. APPLETON AND COMPANY

NEW YORK :: 1922 :: LONDON 
COPYRIGHT, 1922, BY

D. APPLETON AND COMPANY

PRDNTED DN THE UNTIED STATES OP ALERICA 


\section{PREFACE}

IN the following pages it has been attempted to present somewhat specifically "the how" and "the where" of foreign trade.

Attention has been given, moreover, not only to markets and methods, but also to the peoples themselves with whom we are dealing and with whom our international commercial relations are certain to be increasingly intimate as the years pass. H. G. Wells has said, "The last deeision and the greatest decision lies in the hearts and wills of incalculable men." Success in overseas trade pivots upon the men who do the trading. The point of view, the temper, the general traits of the foreigner himself, our prospective customer or seller, are as necessary to know as the world's markets and the business procedure in shipping and merchandising a product overseas.

The means by which men may be prepared for international commerce have been emphasized also at some length, since no more vital subject now confronts us as a people than the fitting of our youth to meet the competitive requirements of eommerce in South Ameriea, in Europe and in Africa and Asia. To diseover and to train men for trade abroad is to-day one of the chief American tasks. We must have trained men to man our ships and to pioneer our banking activities abroad. There is need of trained merchants, trained technieians and mechanical experts, and well-equipped salesmen who have learned to adjust their abilities to the desires and even whims of foreign peoples, whose traits and business procedure are utterly diverse from our own. 
These foreign trade representatives must be of a higher type than formerly-quality bulks big at present. World markets are not ours merely for the asking. These must be won by men prepared in a new school of business, men whose gentlemanhood, geographical knowledge, and the grasp of world polities and racial relationships are equal to their knowledge of particular lines of trade.

That some of our largest houses doing export business overseas, as well as our manufacturers and educational institutions, have recognized this fact and are now carrying on regular courses for training to fit men and also women for this new era in our commercial progress, is a sign of encouragement. Upon no other foundation than that of intelligence and adequate preparation can we as a nation expect to take our "place in the sun" in competition with the experienced nationals, whose progress for generations has depended upon their astute exploitation and successful retention of world markets.

Clayton Sedwick Cooper.

NEW YORK CITY 


\section{CONTENTS}

I. Foreign Trade Requirements .......

Influence of wars upon American trade abroad - New world conseiousness on the part of American business men-American manufacturers require foreign markets-Necessity of geographical and trade knowledge-Some fundamental essentials for success-Mental point of view of the buyer in foreign lands-Reciprocal trade-Transportation-Financial facilities-Team-play and coöperation-Eliminating home competition-The salesman's opportunity.

II. Knoming the Export Business . . . . .

Trade statisties revealing enormous growth of new methods being adopted-The export merchant's qualifications and difficulties-Commission houses-Direct exporting-The export manager-Seeing things "in the big"-Necessity of manufacturer's' personal contact with field-Practical idealism.

iII. Foreign Salesimanship as a Career . . . .

A new opportunity for best trained men onlyNatural qualifications-Necessary equipment includes intimate knowledge of industrial and financial conditions at home-" "Manners maketh the man"-Becoming specialists on a single country-The foreign salesman's decalogue.

IV. Export Advertising: Its Necessity and How ACCOMPLISHED . . . . . . . . . .

How foreign advertising differs from home advertising-Adapting advertising to the tastes of the country-Understanding surface differences and racial and temperamental traitsAdvertising by letter-Local advertising in foreign markets. 
V. Training for Foreign Commerce . . . . .

New demand for properly fitted men-Where training information can be gained-Advantages of college education-Business procedure necessary to be acquired-Vocational studyPractical methods of training used in business houses, banks, and colleges.

VI. Literature aNd Study Courses for Foreign Trade Representattues' . . . . . . . Foreign trade conference classes-Courses given in business houses-Suggestive course of study on sales practice-Foreign advertising courses-General readings on Latin America and a worldwide trade bibliography.

VII. American Shipping and Our Merchant Marine . . . . . . . . . . . .

American shipping, its evolution from clipper ship days to the present-The world's merchant marine tonnage in 1914-War losses in ships-Shipbuilding in different nationsShipping legislation needed-Views of shipping men-The need of a great American maritime leader.

VIII. Marine Insurance . . . . . . . . .

What is usually meant by marine insuranceDiscussion of the most common insurance clauses with explanation of each-Underwriters' responsibility-Carriers' responsibility -Specialization; claims and promises necessary for manufacturers and traders in order to secure marine insturance protection.

IX. Cables: The Nerves of Foreign Trade . .

Facts relative to the history of cable service and the progress of cable communicationHow cable service ministers to international trade-Construction of cables-Inter-America cables-The All America Cables as an example of the progressive spirit of communication between North and Sonth America-The art of using cables-Summary of improvementsPrivate and nationally owned cables. 
X. Financing Foreign Trade . . . . . .

American banks abroad-Financing foreign shipments-Credit versus cash policy-Payments-Detailed steps in an exchange transaction.

XI. Importance and Advantages of Knowing ComMERCIAL LANGUAGES

Worldwide desire to learn English-Necessary commercial languages-Where French, Spanish, Portuguese and other languages are needed -Discoveries along the route of language study-How commercial languages can be mastered-Suggestive list of books for aequiring different languages.

XII. Definitions of Foreign Trade Terms . . 205

The findings of the National Foreign Trade Council relative to terms used in overseas commerce-Nccessity of mutual understanding in the uniformity of terms like F.O.B., C.I.F., ete.-Definitions of export quotations with explicit directions for sellers and buyers-Responsibility of both merchants and exporters in shipping, freight and insurance matters.

XiII. The House Organ in Foreign Trade . . .

Purpose and policy of the corporation magazine-Result of questionnaire conceruing the work of house organs among leading American firms engaged in foreign trade-Educational values-- The editorial function-Correspondents and photographs-Publishing costs-Difficulties confronting the house organ editor.

xiV. Newspapers and Periodicals as Foreig Trade

Bullders · $\cdot \cdot \cdot \cdot \cdot \cdot \cdot \cdot \cdot \cdot \cdot \cdot \cdot \cdot \cdot$ The work of the American press in foreign trade propaganda-Necessity of overcoming adverse criticism of the Unitcd States in foreign countries by presenting in the foreign press the trine attitude of American manufacturers-Periodicals used successfully for foreign trade exploitation-Export trade journals-Local foreign media with a list of anthoritative periodicals in the leading world's 
markets. Mediums described and explained according to the nature of products they are best fitted to present to foreign customers.

XV. Diplomatic and Consular Service . . .

The new demand for commercial statesmenFunctions of Ambassadors and MinistersThe work of the American Consul, his duties given in detail-How the American manufaeturer and exporter should coöperate with our consular and diplomatic officers-The Consul's responsibility to Government departmentsOur foreign Government representatives as related to travelers, tourists and business firms -Suggestive experience of European nations eited relative to the work of diplomatic and consular officers abroad.

XVI. Mutual Markets between the United States AND J JPAN . . . . . . . . . . . .

Influence of Japan's vietory over RussiaJapan dependent upon foreign business-The militaristic versus democratic policies-Signs of liberalism-Factories and labor-Pan-Asian tendencies-Trade with the United States-Recent financial conditions-Character of Japanese imports into the United States-Our exports to Japan-Markets mutually necessary to both nations.

XVII. Strengthening American Trade with China

Understanding the Chinese people-Growth of American business firms in China-Character of market-Difficulties eonfronting American traders-China Trade Aet-History of commercial relations with China-Trade legislation required-Industry exhibit suggested-Making China an "open door" for American commerce.

XVIII. Trade Possibilities and Industrial Progress IN THE Philippines

Westernization of the Philippines-Chief exports and imports-Results of the war-Trade schools-Transportation facilities requiredLabor problems-Difficulties of legislation at long range for the Philippines-The American political dilemma. 
XIX. AMerican Trade with India . . . . .

War has opened new trade doors-Kind of products needed and principal exports-Japanese activities for trade with India-The East Indian method of doing business-Rules for the foreign trader in India.

XX. Can Trade Westerntze Asia? . . . . 307

Significance of Asiatic races in world tradeInherent national differences and oriental characteristies-England's tasks and accomplishments-External rather than spiritual reconstruction.

XXI. Our Trade in the Near East . . . . . . 321

How America has laid foundations for Mediterranean commerce-Why the United States holds the confidence of near Eastern countries -Rich resources of the near Eastern countries -Our trade accomplishments in the past largely without American shipping-New contracts during and since the war-Markets in Egypt, Turkey, Asia, the Caucasus, Greece, and the Balkan regions-American responsibility in developing Mediterranean markets.

XXII. American Overseas Trade with Africa . . 333

The awakening of Egypt-The new spirit of the fellaheen-Imports and exports of Egypt -Algerian development under French leadership-Resources and economic conditions of South Africa-Trade development in the Union of South Africa-American chamber of commerce in South Africa-Industrial development-Work of American engineers and business men-The Belgian Congo-American business in central West Africa.

XXIII. American Commerce with Russia . . •

Uncertainty of present trade situation-Statement of American policy by Secretary of State Hughes-Preparing for Russia's prospective markets-Germany's position in Russian markets-Credit difficulties-Russia's agricultural and industrial possibilities-Railroads needed 
- The timber industry-Mistake of sending inferior men as representatives-Suggestions for salesmen-Necessary to prepare now for entering Russian markets.

XXIV. Markets with the United Kingdon, Canada and Australia . . . . . . . . . • Great Britain as a pioneer in overseas commerce-Reasons for her prestige in her merchant marine and manufacturing genius, colonizing capacity and coal supply-Her financial accomplishments in foreign tradeProtecting the rights of her subjects-A settled trade policy-Markets between Great Britain and the United States-British investments in foreign lands as a means for developing trade -Canadian markets-Reasons for Canada's large trade with the United States-Forest resources-Export and import statisties-Australian markets-Chief exports and industries -Trade with the United States.

XXV. Understanding Britishers: A Necessity for Successful Intertrade Relations . . Necessity for successful intertrade relationsStudy of American and English characteristics as revealed in trade-Necessity of understanding differences of temperament and idealsReserve versus enthusiasm-Necessary for the American to understand English conservatism - American adaptability an advantage in trade relations-Influence of education upon national temperament-Mutual understanding of British and Americans a vital factor in worldwide trade accomplishments.

XXVI. Trade with the New Europe . . . .

Outstanding features of new European markets - New trade with Austria-Hungary, CzechoSlovakia and Baltic States-North Mediterranean coast trade increasing-Belgium markets - United States trade with France-Italy's industrial progress and future prospects through new territory acquired in the warSpain's trade with the United States-Commerce with Portugal. 
XXVII. Caribbean Markets . . . . . . . .

Proximity a factor in overseas commerceMexican resources-Export and import conditions-Cuba: "the world's sugar bowl"-An inereasingly large market for the United States -Markets with Porto Rico, Haiti, and San Domingo-American business-hold upon the Central American Republies-The land of the banana-An example of American vision and industry in Central America in industrial production.

XXVIII. Winning South American Trade • • • • How alone South American trade can be won -Assistance of the Webb Law and Edge Act to American manufacturers-The Panama Canal as a vital factor-Service and capital as prime requirements-Foreign investments and accomplishments in South America-Reasons for South American dependence upon foreign initiative-Chief products of South American export-Things that South America importsMeeting European competition-Following up the admiration gained for us by South America during the war-Careful attention to details in adjusting business relations with South America.

XXIX. Carrying American Ideals along the Routes of World Trade..........

The personality of the business man as a factor in world trade-Is American idealism being earried with trade methods into world markets?-The Americans as utilitarian idealists"The square deal, both ways" applied to foreign trade-America's unexampled opportunity in world affairs.

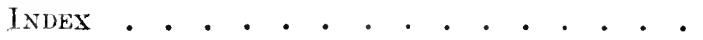





\section{ILLUSTRATIONS}

A cacao tree on a british west african plantaTION . . . . . . . . . . . Frontispiece

Along the canals of china . . . . . . . . . . . 32

Transportation of hides in the streets of calcutta, india 32

A busy corner on the pIER of ONE OF the Large AMErican

iNTERNATIONAL MERCHANDISING COMPANIES . . . . 33

IN THE DAYS OF THE "CLIPPER SHIPS" OFF THE COAST OF

PERU IN 1865 . . . . . . . . . . . . . . . 126

Grain elevators and docks at buenos aires" . • . 127

Cerlonese workmen hindling tea chests . . . . . 260

A picturesque group of tea pICKers . . . . . . . . . 261

The first LAP iN tIIE JOURNeY OF CEYLON TEA TO AMERICA 280

COOLIES Carrying CHESTS OF gOODS ON THE HANkOW

WATER FRONT . . . . . . . . . . . . . . 281

Gathering grapes in a large brazilian vinetard . . 338

A MaRKet at aCCRA, british WeSt aFrica . . . . . . 339

Spinning wool and weaving CaShMere shawls . . . 352 RUSSIAN ClOTh MARKET . . . . . . . . . . . . 353

A lumiber railway piercing a brazilian jungle . . . . 404

TRANSPORTING WHEAT FROM ONE OF THE LARGE HACIENDAS'

in ARGENTINA . . . . . . . . . . . . . 405 



\title{
FOREIGN TRADE MARKETS AND METHODS
}

\author{
CHAPTER I \\ FOREIGN TRADE REQUIREMENTS \\ Trade is Peace.-Ex-President Taft.
}

Wars have had direct and far-reaching influence upon Ameriean foreign trade. It was during the Napoleonic wars, lasting upwards of twenty years, that young Ameriea obtained and accepted her first opportunity to enlarge her trade to world proportions, building up her mercantile sailing flcet until between the years 1800 and 1830 we carried in American ships upwards of 90 per eent of all our foreign trade products. The Civil War, or rather the sectional differences between the South and North preceding this war, were largely instrumental in demolishing the Government subsidies given to transatlantic shipping and in fettering northern shipbuilding and giving an open door to the competitive trade of foreign shippers in our markets. Our war with Spain not only gave us new interests in Cuba and the West Indies but it extended our trade responsibilities in the Orient and scrved as an entering wedge to new commercial adjustments with Asia. The European or World War, even more decidedly than any former conflict, has served to break the traditional geographical and industrial isolation of the United States, accomplishing in such lines as shipbuilding, finance and seientific industry, results that have amazed our own countrymen and placed us 
under direct obligation and necessity for a greatly enlarged foreign commerce.

What years of propaganda, literary and political, have failed to accomplish in the way of building up a new merchant marine, the war has accomplished at a single stroke, and American ships again are found upon the "seven seas." Our country through the exigencies of war has become the creditor nation of the world and by reason of our characteristic material accomplishment in technical and industrial construction, together with our financial precedence, we have become involved responsibly in organizations intrusted with the reconstruction of large portions of Europe. Our greatly enlarged activities in Latin America during war time, and particularly in view of the greater shipping facilities utilized with our southern neighbors, have brought about a new era of trade opportunity on this continent, while in a manner never known before, the widening of the horizon of our people by reason of knowledge and experience, particularly in the European conflict, has brought us into new trade relationships with Africa and the Orient.

That foreign trade is absolutely essential to furnish a field for our growing manufactured products is vividly shown by a statement made recently by Mr. O. P. Austin, statistician of the National City Bank of New York:

United States manufacturers broke their own record and the world's record in the value of manufactures turned out in 1919. Preliminary figures of the 1920 census covering the value of all manufactures produced by the factories of the United States in the ealendar year 1919 show a grand total of $\$ 62,500,000,000$, as the gross value of the 1919 output, against $\$ 24,250,000,000$ in $1914 ; \$ 20,500,000,000$ in $1909 ; \$ 14,750,000,000$ in 1904 , and $\$ 11,500,000,000$ in 1899 . The value of the 1919 output is two and one-half times as much as that of 1914, over three times that of 1909, four times that of 1905 and more than five times that of 1899 , only twenty years earlier. The increase in the five-yearcensus period, 1914-1919, was 158 per cent against an average quinquennial increase of $28 \mathrm{per}$ cent in the preceding five-year 
periods represented by the census reports from 1899 to 1914 . The highest percentage of gain in value of manufactures turned out in any of the preceding quinquennial periods was that of 1904-1909, in which the increase was 39.6 per cent as against 158.1 per cent in the quinquennium 1914-1919.

Not only is the value of our output of manufactures in this latest census record by far the "biggest ever," but it means that we are now producing a much larger share of world manufactures than ever before and at least twice as much as that of any other country of the world. Prior to the war, we were producing about 30 per cent of the factory output of the world, our total as shown by the 1909 census, having been $\$ 20,000,000,000$, the United Kingdom and Germany at that date estimated at $\$ 9,000,000,000$ each; France $\$ 7,000,000,000$, and the factory output of the remainder of the world $\$ 20,000,000,000$, making the estimated value of world factory output in 1910 at approximately $\$ 65,000,000,000$, of which we supplied $\$ 20,000,000,000$, or about 30 per cent of the total. Now our latest official record, covering the output of the year 1919 , shows our own total at $\$ 62,500,000,000$, or nearly as great as that of the entire world a decade earlier, while the best estimates obtainable for the outturn of other countries suggest that our share of world output of manufactures in 1919, the year following the close of the war, was rather more than 40 per cent, as against 30 per cent in the period immediately preceding the war.

It is unnecessary to go further into a statement of our opportunities, or to emphasize the fact that this new after-war period is to furnish the arena in which the United States is to prove for many years to come whether she is to become a leading world factor in trade, or is to drop back to her original position of third or fourth or fifth place among nations in foreign business.

To-day our men of affairs, manufacturers, merchants, political leaders, financiers and mariners are becoming conscious of the fact that we are at the threshold of a great possible enterprise in American foreign trade. The ground has been cleared for action but the battle has not been won; indeed, it has hardly been begun. During the next decade the United States will be chal- 
lenged to prove her ability to add to her achievement at home quite as great achievements in extending her genius and talents for trade and industry abroad.

In view of the momentous issues it is well to have in mind the essential requirements which we shall be called upon to meet to compete successfully with other foreign traders.

Whether a man be a manufacturer, a steamship man, an advertiser or a banker, a salesman or a manager in a foreign office, it is essential to remember that no ingenious methods or tacties of trade can possibly substitute for a broad knowledge of foreign peoples and an ability to adapt our plans to the requirements of business in these lands. This will require brain power as well as activity. We are inclined to emphasize in this country physical activity and hustle at the expense of ideas and mental leadership. It is possible to be ever so energatic and yet lose our customers because we fail to think in their terms.

Our geographical knowledge is lamentably scant. During a visit to South America not long ago we discovered an American automobile firm about to establish its central office for South America in Quito, Ecuador, under the apprehension by looking at the map, that this would be a suitable central place for reaching all parts of the West Coast. Another manufacturer cabled his agent at Buenos Aires to mun up to Para, Brazil, over the week-end for the purpose of elosing a business deal, thinking that the agent could easily get back to Buenos Aires by the middle of the next week. This somewhat juvenile ignorance of distances did not take into the reckoning the fact that the agent would consume ordinarily not less than ten days simply in travel one way between Buenos Aires and Para. This ignorance of places and distances was almost as impregnable as that of a certain young would-be trader who asked the writer a few years ago if Thibet was in Egypt.

$A$ letter came to us not long ago from a man wishing to go to Brazil to engage in the chemical line. He stated 
that he had a knowledge of Spanish and French but that he understood German was spoken to a considerable extent in Brazil, inquiring whether we thonght he should master German before going to this country. Upon inquiring whether he knew Portuguese, which, of course, is the language of Brazil, we discovered that this subject had never occurred to him.

Furthermore, no trader is fitted to build up a business in a foreign country unless he has studied somewhat the historieal background of that country. What is the temperament of the people due to racial or hereditary influences? What kind of methods and what sort of persons using these methods are acceptable in their eyes? What competition must be met? How about commercial treaties, social eustoms, methods of payment and politieal stability of the country? To lunge into foreign trade without such knowledge is suicidal. It would be like the manufacturer who sent a large shipment of pocket-knives to China only to learn later that the Chinese had no poekets in their clothes. An old college president once said to a prospective graduate about to engage in business:

Your first asset is the ability to get the point of view of your customer. Without that everything else is useless.

A first prineiple of successful business abroad is what Confucius used to call "mental hospitality"- the faculty of projecting your imagination into the viewpoint of the people with whom you are to deal. This means the doing away with preeoneeived prejudices and suggests the acquiring of what President Butler of Columbia University has called the "international mind." A generous hospitality of mind and spirit toward people with traditions and ideas quite different from our own, a striving to be simpatico as they say in Latin America-these are indispensable eonditions of success in foreign enterprises.

There is something more required of the foreign merehant than the qualifications of a merchant at home. He must be more than a manufaeturer or a banker, since this 
merchant must have a wide knowledge of international business and be possessed of the faculty of foresight, and more than all, possess the ability of keeping the eustomer in mind. A banker's problems ar'e comparatively easy, providing he holds to a conservative poliey in granting credits. The foreign merchant, if he is an exporter, must keep in mind the man to whom he sells goods as the chief subject of his thought. He is dealing in exporting with individuals. In importing, on the other hand, it is a subjeet of merchandise, the goods, that the merchant must have foremost in his thoughts. In all of these matters, however, one of his first ideals must be the rendering of service. $\mathrm{He}$ is not carrying on a one-sided transaction. Foreign trade means something to sell and also something to buy.

An example of what is meant by service came to our notice reently from an experienced exporter. He eited a transaction with a large customer in Ecuador, who, among other items, ordered a number of cases containing porous plasters, but in giving contents of the eases stated boxes by the gross instead of by dozens. The man receiving the order coneluded that the customer had ordered enough plasters to supply the whole of Ecuador for years, and feeling that there must be some mistake, shipped one-twelfth of the order, ealling the attention of the customer to what was thought to be a mistake and stating that if the entire order was wanted the customer should cable at the exporter's expense. This act of consideration on the part of the exporting house so pleased the Ecuadorian customer that he beeame attaehed to this New York house permanently and, in fact, never bought goods from any one else after this act of consideration.

Trade is what the word signifies-a reeiprocal proeess, importing as well as exporting. It has two sides and there are two parties involved: the rights and needs of both must be taken into consideration. The neeessity of buying as well as selling was brought to attention vividly after the World War when our export trade balance piled up at the rate of four billions of dollars a year with all the 
dangerous consequences attendant upon this one-sided arrangement. During the last part of 1920 and in the year 1921, the depression in foreign business consequent upon foreign exchange and falling prices has brought out even more vividly that no country lives to itself alone. As this is being written it is estimated that upwards of $50,000,000$ tons of American goods are lying in Latin-American warehouses, the buyers refusing to accept them and pay stipulated prices because of the fall in exchange in nearly all these South American countries since the trade transactions were made. To fulfill the original contracts would mean financial ruin doubtless to many a foreign firm. The situation both at home and abroad has emphasized the fact that trade is consequent upon conditions and eircumstances not alone in the sclling country but in the purchasing country as well. A wise, far-seeing merchant must make certain of his customer's ability to pay and also have the vision to see tendencies and guard both himself and his customers against such world-wide business calamities as the depression of 1920 and 1921 witnessed. To make trade reciprocal and successful the home merchant must know and be prepared to help his foreign client and customer. Service is a big word in overseas commerce. It is a potent means for assuring trade reciprocity.

The war has startled us into the realization of the vital necessity of sea power. Transportation is the twin brother of trade. A country may have mines and products of the soil in abundance, but without railroads and ships may be profited only slightly by this fact. In the Philippines we met an expert in the lumber business who had been sent out there to investigate the field for a large syndicate in view of the investment of a huge sum of money in the lumber business in these islands. This expert was amazed to realize that despite the large timber reserves which he found, he could make no favorable report to his syndicate, since there was no possible means of getting this timber to a market port. Brazil, for example, has inexhaustible riches of mines, woods, agricultural and grazing possibilities, but her 
vast territory is now locked to the world because of inadequate means of getting these riches out to the seacoast. Roads-country roads, railroads-these are indispensable requirements for foreign trade.

We ought not to forget soon the fundamental necessity which for four years was drummed into our ears by the slogan: "Give us ships!" There are many indications pointing to the fact that a new American merchant marine is forthcoming. Let us realize, however, that this is not yet an accomplished fact and that if attention is not given in the near future to legislation which will make it possible for American ships to compete with English, German, French, Italian and Japanese lines much of our prestige and opportunity during and immediately after the war will be forfeited. Our provincialism and fear of entangling alliances, together with lack of world perspective and knowledge on the part of our lawmakers must be changed, and speedily, if we are to meet the requirements of the new era.

We are advancing in experience at present relative to the matter of proper facilities such as our own banks and the establishment of oul own offices, and the proper use of such agencies as commission houses, export departments, marine insurance, traveling salesmen and a general knowledge of financial matters involved in credits, trade acceptances, merchandise documents and other means familiar to our trade competitors in other nations, as well as such details as packing, marking and the transportation of our goods. The National City Bank has led the way in Latin America in American banking matters and other of our banking institutions, notably the Guaranty Trust Company, are following up the advantage in lessons learned. American chambcrs of commerce in foreign cities are helping greatly. That we have yet more ground to cover along each of thesc lines is evident to any one who happens to attend a conference or convention of our American men of business whose questions concerning the fundamentals of foreign trade reveal the unassailable fact that our men 
of affairs have achieved their reputation for business almost entirely at home, while the extension of this business to foreign lands is yet more or less in a terra incognita. We have the raw materials, many food supplies and the manufactured products which all the world needs; the machinery; for selling them, transporting them, and suiting our customers in price and detail is yet largely to be supplied.

Another factor which has far-reaching influence upon a nation's commercial success in foreign countries has been the willingness to invest capital in industrial enterprises. The opportunity and the advantage of such investment was elearly shown recently in an address made by Mr. John S. Drum, President of the American Bankers' Association:

It is useless to grow commodities we cannot use or sell. Foreign nations which need our commodities have only one thing to sell to obtain money with which to buy our goods-that is, securities in their productive enterprises. And we, prominently the creditor nation of the world, are the one people who can invest in those productive enterprises of other nations and thus enable them to trade with us.

It is what England and Holland and Belgium and France and all great trading nations of the old world have done in building up markets for their products. Their foreign investments enabled foreign countries to produce more than before and therefore increased their ability to buy.

None ever possessed the opportunity that is ours to-day. By foreign investment we may help them to restore their wealth destroyed in war and to reduce their debts, but at the same time we shall help ourselves even more by restoring their ability to buy our goods and our own ability to dispose of our excess products.

In a sense which it is difficult to obliterate, trade follows the dollar. The European nations that have devoted large investment to the building of railways and dock improvements in South America have thereby furnished markets for their own manufactured products and secured the particular good will of the country in which the investments have been made. Foreign investments not only carry with them new markets for our goods, but also men of the nations 
investing and these men together with capital produce the ties and influential relationships conducive to the future building of trade. Undoubtedly the large number of foreign loans which have been finding more or less ready aceptance in the United States since the war will add a liew interest upon the part of our people in the countries abroad and in their products and progress. Furthermore, financial investment in most of the countries of Latin America at present is not only safe investment but in many cases bears the promise of being more profitable than many investments at home.

Provided the requirements narrated above are at hand, without a coördinated and coöperative system by which our American business men may work together under favorable conditions and in the spirit of mutual advantage, we shall strive in vain to win our rightful share of foreign commerce. The war has proved conclusively that great results can be accomplished by team play and by learning how to work together to a common end. Kipling's verse should be graven upon the doorposts of our foreign trade policies:

\section{It ain't the individuals, \\ Nor the army as a whole, \\ But the everlasting teamwork, \\ Of every bloomin' soul.}

We must knock out competition at home where that competition hamstrings our national business: we must get over fear of governmental aid and see to it that laws are enacted commensurate with those under which European nations are now conducting their overseas commerce. Our antitrust legislation needs to be reformed to meet existing conditions. Such enactments as the Webb Bill and the Edge Bill and the recent Jones Bill are along the lines of necessity and give hope for our foreign business. There is nced to-day for the raising up of maritime leadership able to coördinate our shipping interests through adequate legislation and the establishment of private ownership and management. The stability of our transportation 
at home in the realm of our railroads is almost as vital to our foreign trade as it is to our domestic commerce, as foreign trade begins usually on the home railroads. The shore, where the products are transferred from cars to ships, should be considered as a transfer point only. Coöperative, economic agreements are the keys to world probleins and we must look for these new agreements among producers at home if our trade is to mass all its strength and eliminate disputes and friction. It goes without saying that this spirit of coöpcrating business activities cannot exist with constant antagonism between capital and labor, nor while political umrest under the guise of Bolshevism, destructive strikes, or any phase of class war, thrusts at the vitals of success of American foreign enterprises.

It has been said repeatedly that the new era opening beyond the World War period is to be a "business man's cra," that the commercial and industrial leader is to be the new diplomat of the coming decade, but this leadership which involves coöperation between science and industry, between the man who works with his hands and the man who works with his brain, this joining into one the potent forces of business organization, are problems that will not scttle themselves. They require the highest intelligence and thoughtfulness on the part of our most able men of affairs, and more study than they have yet received. If we are to have a league to enforce peace, binding together the hearts and hands of men around the world, this league spirit must have its primary and efficient exhibition in the friendly unity of those who are responsible for the material and industrial foundations of a world now in its remaking. 


\section{CHAPTER II}

\section{KNOWING THE EXPORT BUSINESS}

Knowledge is more than equivalent to force.-Sam'l Johnson.

According to a well-known export manufacturer, "export trade is national insurance." It has been the burden of the writing by foreign trade experts as well as the speechmaking at conventions of manufacturers for at least a decade in the United States, that the Ameriean factories in order to keep going the year around must have an outlet outside the country for at least 25 per cent of their manufactured goods. Until comparatively recently this truth has not taken possession widely of the consciousness of American industrial leaders. In many cases manufacturers have taken a dip into foreign trade at times when business was slack in this country or when some partieularly opportune opening appeared. As American trade increased, or through a lack of knowledge, incompetency of agents or mistakes in method, these same American manufacturers were inclined to drop their foreign activities and to devote themselves again exclusively to the home market.

There have been also, and stifl exist in the country, shortsighted manufacturers who seem to follow the political slogan of nonentanglement in trade alliances abroad. We have heard many a manufacturer say that our country is big enough to furnish all the opportunity needed for trade and they would seem to wish to ereet a kind of Chinese wall around the United States as far as trading is concerned. 
These conceptions are now being branded both as unbusinesslike and also as inimical to the proper trade expansion of America. Ameriean business organizations have been reorganizing their entire activities, both domestie and foreign, and in this reorganization the export end of the work is receiving both financial support and better trained leadership. It is being realized that any form of exclusiveness in trade means paralysis, and that the nixture of international currents of thought with merchandising is in line with progress and suceess. Practical proof of this fact is demonstrated by examining the total trade statisties of the United States with various foreign countries. For the fiseal year ending June 30,1913, the total foreign eommerce of the United States was $\$ 4,278,892,000$. During the fiscal year ending June 30, 1918, this total trade had mounted to $\$ 8,865,366,000$, or a pereentage of inerease amounting to 107. While the greatest foreign commerce of the United States for the year 1918 was with the United Kingdom, amounting to $\$ 2,185,945,000$, our trade with Latin America in this year, 1918 , was $\$ 1,804,583,000$. Next in volume of commeree was our trade with Canada, which in the year 1918 amounted to $\$ 1,212,745,000$. The eight other countries with which the foreign commerce of the United States in 1918 amounted to more than $\$ 100,000,000$ were as follows:

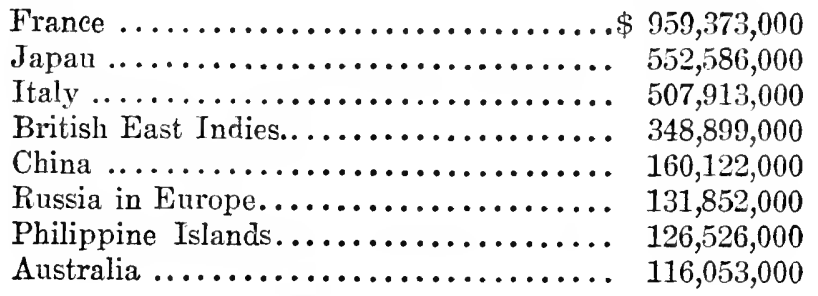

For the calendar year 1919, the total foreign commerce of the United States was $\$ 11,824,790,922$. Countries, in that year, having more than $\$ 100,000,000$ commerce with the United States were as follows: 
United Kingdom................\$2,587,746,789

Canada ........................ 1,228,940,867

France ...................... 1,017,179,221

Japan . .................. 776,217,616

Cuba ....................... 697,001,485

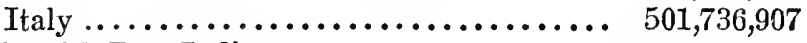

British East Indies. . . . . . . . . .... 403,664,631

Belgium ................... 385,582,408

Argentina ................... 355,057,791

Brazil ....................... 348,266,929

Netherlands .................... 330,605,243

Mexico ....................... 280,381,477

China .................... 260,224,557

Denmark ................... 170,159,228

Australia ..................... 153,242,777

Spain ..................... 152,314,653

Sweden ................... 146,792,062

Norway ................... 142,505,843

Philippines .................. 136,841,289

Chile ................... 135,563,451

Dutch East Indies . . . . . . . . . . . 125,320,080

Switzerland .................. 103,833,372

Germany .................. 103,369,455

The following table shows the condition of our commerce both export and import since the year 1880:

\begin{tabular}{c|c|r|r}
\hline In & Exports & \multicolumn{1}{|c|}{ Imports } & \multicolumn{1}{c}{ Total } \\
1880 & $\$ 836,000,000$ & $\$ 668,000,000$ & $\$ 1,504,000,000$ \\
1890 & $858,000,000$ & $789,000,000$ & $1,647,000,000$ \\
1900 & $1,395,000,000$ & $850,000,000$ & $2,245,000,000$ \\
1910 & $1,745,000,000$ & $1,557,000,000$ & $3,302,000,000$ \\
1913 & $2,466,000,000$ & $1,813,000,000$ & $4,279,000,000$ \\
1918 & $5,928,000,000$ & $2,946,000,000$ & $8,874,000,000$ \\
1919 & $7,920,000,000$ & $3,904,000,000$ & $11,824,000,000$ \\
1920 & $8,228,000,000$ & $5,279,000,000$ & $13,507,000,000$ \\
& & & \\
\hline
\end{tabular}

In the phrase of the exporter previously quoted, a policy to do business wherever business can be done in any part of 
the world furnishes a trade insurance against panics, labor troubles and depressions at home and directs into our home business a fresh stream of interest and enterprise. As a writer in World's Markets said:

Panies are not world-wide-they don't occur in all places simultaneously, and the man who has a market in South Africa and in Russia and in China and in Siberia, as well as in Europe and South Ameriea and Australia, is pretty sure that if he cannot sell his product in one place, he can sell it in another; he has taken out the best kind of insurance against hard times for his business, and incidentally for his employees, his bankers, his suppliers of raw material and the local tradesmen in his community.

Furthermore, it is being realized that the American trader is not outclassed by any other national when he devotes himself seriously to the task of securing markets for his goods in foreign lands. Go wherever you will to-day into almost any part of the earth and you will find the American trader, when properly trained, holding his own in competition with the Englishman, the German, the Frenchman, the Spaniard or the Japanese. The new influences and prevalence of American trade and shipping were brought home to us recently by the statement of a man who has just returned from a long round-the-world voyage on a freight ship. He stated that in every port, virtually without exception, which he had visited (including the main ports of Japan, China, Philippines, East India, Alexandria, and the chief ports of the Mediterranean Sea) he counted from 6 to as many as 20 vessels flying the American flag. We recall vividly the fact that on two journeys around tho world before the war we saw only two ships in Oriental ports flying the Stars and Stripes, and these were very insignificant oil steamers of the tramp variety.

Success, however, in this vital field is achieved only when the American trader appreciates seriously the vital necessity of securing firmly his business in foreign trade markets, and sets his mind earnestly towards permanent accomplish- 
ment. Witness for proof the success abroad of the Singer Sewing Machine Company, the Standard Oil Company, our typewriter, kodak and automobile companies, the Ingersoll Watch Company, and notably our American steel and agricultural machinery firms.

It is encouraging in this connection to note that while we have yet to learn much relative to methods and the adjustment of the point of view for trade, with Latin America for instance, the late statistics concerning this trade reveal the fact that the American exporters and manufacturers in 1919 liad the largest total trade with South America of any nation. Before the war, the United States was second to Great Britain as an export nation, while in the year 1919 our commerce, according to the reports of the Bureau of Foreign and Domestic Commerce, more than doubled that of the United Kingdom. Our trade with South America has doubled since 1914, while our exports to the Orient and Australia underwent even a greater gain.

We are now at the point when we must understand the "how" of foreign trade. We have many men capable of carrying on commercial relationships with foreign countries. They are being trained both in the practical and theoretical schools of overseas commerce. We have the manufactured goods and products of our national, inventive genius and fabricating skill, particularly those manufactured goods in the realm of heavy machinery, steel products, office specialties, antomobiles, hardware, shoes, hosiery, sewing machines, cash registers, typewriters and a hundred other specialties germane to American inventive and skillful production. Now we must devote unqualified and studied attention to the methods of the game. The secret of success in foreign trade is largely dependent upon the judgment of the manufacturer in choosing the proper method to market his particular commodity. There have been probably more failures and losses in this line than in any other.

In the first place, one must take for granted that the existence and knowledge of shipping arrangements are 
present. This is more important than ever before, for it is estimated that American ships are now carrying approximately 50 per cent of American goods to foreign shores. Our own banking arrangements are also coming along; a nation eannot make a suecess of foreign trade without the permanent service of banks owned and controlled by that nation. Other agencies, such as marine insurance and knowledge of proper documentation, packing for export, eable service and aequaintance with the tastes and desires of foreign people are vital adjuncts to foreign commerce, all of which are gradually being learned.

The Export Merchant.-The export merchant chooses a fascinating though complicated career: he may decide, in the first place, to purchase outright for his own account; to purchase on commission for his principals abroad; or to serve the special lines and the factory arrangements without extra charge to a customer abroad.

Mr. John F. Fowler, one of our oldest and best known export merchants, has summed up certain of the qualifications and the necessary knowledge of the export merchant as follows:

$\mathrm{He}$ is an instigator of business, by constant vigilance, whether in commodities or manufactures; and a great pioneer in foreign markets. He must be in familiar and constant eontact with factory representatives at the home end, so that he shall not be tardy in reporting prospects to his foreign customer on those articles singled out as likely to interest bim. This involves not only a close watch of this end but also the ever changing conditions abroad. $\mathrm{He}$ has also to be keen in the matter of ocean transportation, with ever an eye on the constantly fluctuating freight rates and ready for every shipping opportunity, if he is properly to serve and retain his foreign customer. Frequently foreign business calls for special services, here and abroad, both laborious and expert in performance. He must also be familiar, for quiek action, with all the consular and Governmental formalities which vary with every country, especially those of Latin America. He must be organized for rapid preparation of documents, embracing multifarious details, in such perfeet order and so explicit that the foreign customer ean dispose of any given package, on its documentary 
description, without having to open and check over its contents before it can be sold or shipped away to some interior point. And these documents must go forward not later than the carrier of the goods. This demands trained office help, necessarily competent, to prepare documents in foreign languages, and far beyond the routine of home business. Unless all is done correctly, the export merchant has constantly to respond for claims for expenses arising from flaws in his documents; and, with many countries, this is a very serious responsibility indeed.

Wholly apart from the fore-going, the export mercliant has to finance his shipments, not only eash payments here for what he has purchased, but also heavy cash disbursements for ocean expenses; and, furthermore, extend eredit to his foreign customer. Thus he is not only merchant, but banker as well; and has usually to earry credit risks as long as six months, with all of the financial risks thereby involved.

The difficulties and the vexations of the export merchant are numerous. Acting as a go-between with the home manufacturer on one end and the foreign customer upon the other, his duties carry him into almost every kind of exigency relative to trading, banking, transportation and contact with government and business officials. Local disasters and financial crises, famines, floods and fires, as well as political and revolutionary changes are ordinary obstacles in his path. His goods may be subject to loss by earthquakes and other unforeseen developments. Such periods as the later part of 1920 and the early part of 1921, when foreign exchange and the reaction from war presented innumerable obstacles, furnish an example of some of the contingencies connected with the export merchant's aetivities. As one man has stated it,

The export merchant is constantly between the devil and the deep sea.

While it is thought in some quarters that the business of exporting is an easy road to wealth, those who best know the game realize that it is only through very careful adherence to the best tried laws and regulations for for- 
eign trade added to years of experience that the export merchant can obtain any considerable returns for his labor. It has been stated by men in this field competent to speak on the subject that the export merchant has been able scareely to average $21 / 2$ per cent on shipments of manufactured goods, a much smaller margin than would satisfy our domestic merchants who are not called upon to face foreign contingencies, such as inevitably bad debts and a series of conditions which distance and vary. ing nationalities impose upon the foreign merchant. The exporter must depend upon big turnover in eommodities; he must rely upon his judicious action in times of fluctuating markets and his broad judgment of world eonditions to enable himself to show a profit on the year's trading.

It is only when the manufacturer and the export merchant understand each other's problems and begin to eoöperate, as has been the case in certain European nations, that many of the difficulties of the pionecr exporter are obviated. The American export merchant has not been and is not now inclined to look to the Government for support, as has been true in the past with certain European export houses. Indeed, he desires usually to be freed from the often mistaken and hampering regulations of politicians both in navigation and merehandising methods. The ranks of foreign traders are filled usually by wide-awake and capable men who, like the Chinese, are not interested so much in the particular form of govermment as in the controlling wish that the government, whatever it may be, keeps its hands off the traders' specialistic task. The exporter is worthy of being placed in the professional class of eitizens and he should be given a free field for his action, being relieved from the anxiety which is eonsequent upon the decisions of government officials at Washington, who too often know little or nothing about the vexatious problems attendant upon doing business with people in alien lands.

In spite of the obstacles which confront the international merehant, however, there is a growing confidence 
in the fact that the Ameriean exporter, as a steamship man and banker, and as one chicfly interested in the reciprocal export and import trade of the country, is developing the capacities for permanent suecess in this field. His future depends very largely upon the quality and the training of the men who will be attracted to this service. With the coming of settled conditions there is quite certain to be revealed fresh evidenees of the new interest in overseas commerce on the part of Americans and with our new ships and our new entlusiasm there is little doubt that the means will be found to compete successfully with export traders of any and every land.

For those who are about to embark on this career, we would point out the diffieulties as well as the expanding possibilities for useful and profitable service. The export merehant does not choose an easy job; yet it is one which repays many fold, not only in monetary return to the suecessful trader, but also in the satisfaction that he is helping to extend the borders of civilized commeree, than which few accomplishments are more honorable and worthy of respect.

The Commission House.-Among the outstanding methods which are indispensable, and which the exporter and trader must master, is a lnowledge of the somewhat intricate workings of commission houses.

This agency has linked so successfully American manufacturers with foreign markets as to become a permanent organization through which foreign markets can communieate and do business with our country at those times when the American manufacturer from various causes loses his interest in foreign trade. The commission house has built up its conneetions and become so effieient in its lnowledge of all the eomplex arrangements relating to overseas trade that it is in a position to be of indispensable assistance to the manufacturer who wishes to begin the exploitation of his goods in forcign lands.

The original purpose of the export commission house was to act as a resident representative of foreign export- 
ing and importing firms accomplishing on a commission basis the buying and selling of goods through its knowledge of markets at home and abroad. In addition to acting as a selling agent the commission house is obligated to secure the best possible priees for import consignments and, on the other hand, as purehasing agent to secure the lowest possible priees on goods ordered for export. With these duties in mind the eommission house has built up its branches to handle effectively and expeditiously the work of its clientele, and in this eapacity alone there is little doubt but that this form of doing business overseas will continue with various modifications in the years to come.

In addition to this function of acting as a go-between, the export commission house has gradually added other activities, securing often its own shipping lines and in certain cases establishing its own bank, and, what is even more distinctive, developing its work into a trading company, establishing its branch offices, warehouses, and storerooms with stocks of goods in various parts of the world. In other words, the commission house has evolved in many cases into an international merchandising or trading house. The exporter operating on eommission has evolved into an export merchant, buying and selling for himself goods and produets wherever it seems feasible, and through his genius for organization, proving himself capable of combining the qualifieation of merchant and banker with that of steamship man and export trader, equipped with a knowledge of language, correspondence, advertising and selling activity, together with managerial ability on foreign soil.

As an example the house of W. R. Grace \& Co., which is thought of by many to be simply a commission house, has developed into a great international merchandising organization. The house is like a great tree whose roots or feeders have beeome large industrial plants established by the company, such as their nitrate plants and woolen mills in Chile, their cotton mills, sugar fae- 
tories and mines in Peru and Bolivia. The trunk of the tree is naturally the merchandising of its own products as well as a vast number of other materials handled, such as machinery, tea, coffee, cocoa, hides and skins, chemicals, cereals, fertilizers and scores of other articles. Among the branches of this tree are one hundred and fifty different offices and agencies owned or operated by the company in twenty different nations; W. R. Grace \& Co.'s Bank, through which international banking operations are carried on ; shipping lines running not only to different ports of South and Central America from both the Atlantic and Pacific Coasts, but also lines running to the Far East and literally around the world; a marine insurance department; a cable department; together with particular agencies for welfare and educational work, and the publication of their own periodicals at the home and certain branch offices.

One of the directors of this firm has stated the object and intent of the company:

We are building always; we consider ourselves to be merchants primarily, but the activities of the company are many and diverse. We are industrial developers, steamship men, bankers, nitrate merchants, as well as promoters of all kinds of public service and industries-everything, in fact, that tends especially to the development of the countries where our activities have gone.

Direct Exporting.-If the manufacturer desires to conduct his own foreign trade without using the intermediary of a commission house, or in other words, follows the direct exporting plan, he must begin with a well-thoughtout policy, organize an export department and be ready intelligently to push the sale of his goods in a foreign country. Among the agencies which he will need to consider are a competent executive at the head of the export department, a branch office or responsible agent in the foreign country, the use of traveling salesmen and the consideration of such matters as mail-order plans and advertising methods.

The disadvantage of this method of direct exporting 
lies ostensibly for the new foreign trader in his lack of knowledge and experience of the intrieate methods of foreign commerce, while among its advantages must be considered the fact that the manufacturer himself has that important asset of being brought direetly in touch with his constituency in foreign countries, and all efforts of advertising and salesmanship go directly to building up a pelmanent, direct, interrelated trade between himself and his foreign elients.

In either of these methods a large secret of success lies in the manufacturer's ability to keep closely and personally in contact with his representatives. No manufacturer can expect to get far in foreign trade who "farms out" his responsibility to any manager or organization whatsoever, thinking because he has chosen an acceptable method of foreign trade this method will take eare of itself without his constant thought and attention. It goes without saying that in choosing salesmen or agents for his produet he should endeavor to get men who will devote their energies as exclusively as possible to his partieular article or articles. When agents or representatives are selling fifteen or twenty different kinds of merchandise for various manufaeturers, it stands to reason that eaeh manufacturer is sure to receive only a minimum of his possible activity or concentration. It must further be realized that the manufacturer who chooses the direet method of conducting his foreign activities will require a considerable amount of eapital for the development of a particular line of business and with that eapital he must unite both time, energy and thoughtfulness in working out with his export manager the details of his plan. We would recommend that the manufacturer who plans to engage in new foreign business directly or indireetly should keep in close touch witl the Burean of Forcign and Domestic Commerce in Washington, D. C., from which department he will be able to gain useful printed information in answer to his questions. Among the topics of which the American mannfacturer should have a working knowledge are a study of the 
world markets in order to find out where his particular products have the best possible chance for sale; an examination of the export policies and export houses adopted by successful foreign traders; the knowledge of the qualifications and requirements for a good export salesman; together with attaining a grasp upon the methods of financing, shipping and the somewhat intricate export technique associated with international laws and tariffs, as theso affect the carriage and the introduction of various products into eountries other than his own.

The Export Manager.-The office of export manager has come to be an important one and in addition to the men who oceupy this position several women hold positions as export managers for trading houses in the United States. While formerly this officer had little or no training and frequently limited knowledge concerning overseas markets and eountries, depending largely upon his genius of salesmanship applied to new fields, it is becoming more and more important for a manager to broaden his knowledge widely in such subjects as exporting practice among the leaders in foreign trade, foreign languages, world markets, methods of export sales, shipping and banking facilities. It is important that this man should be more than a routine manager, for this office requires executive ability and a broad human knowledge and quick adaptability to conditions and customs other than our own. Frequently, this manager has at his hand what is called an "export technician" who helps to carry out his strategic ideas in detail.

In relation to the qualifications of such a manager, $\mathrm{Mr}$. George C. Vedder, whose book entitled American Methods in Foreign Trade published by the McGraw-Hill Company, will be found useful in this connection, suggests that:

Without possessing in some degree such qualities as breadth of vision, executive ability, a fair and open mind, ingenuity, farsightedness, systematic industry, patience, intellectual and moral honesty, and practical idealism, only a moderate success can at best be achieved. 
It is necessary here as in other important posts of leadership in foreign business that the man keep himself suffieiently free from trammeling and perfunctory detail. To "see things in the big," or, as one has expressed it, "see big things big and small things small." It is a position requiring farsightedness as well as effieieney and it requires the ability to make independent and prompt decisions.

Practical Idealism.-There is also a very necessary characteristic which Americans possess inherently and which the export manager of trade needs primarily if he is to succeed. We have sometimes called this utilitarian idealism, the eombination of the ability to see and to dream dreams, and at the same time to keep one's feet on the earth and carry out those dreams. It means adding to business abilities enlightened aims and an unselfish appreciation of humanity. A sympathetic understanding of people, whatever may be their religion, their race, their temperament and environment, is positively necessary.

It is in this element of practical idealism that the Ameriean has a particular chance to develop far-reaching suecess in the solution of foreign problems and the capture of foreign markets.

In a land where the word "utility" is ubiquitous, and in an atmosphere where a dreamer is supposed to be a visionary, the union of the two in one individual would seem at first to be an irreconcilable anachronism. Nevertheless, the idealism of the twentieth-century American is a very real thing, and it has never been more aceurately designated than in a plusase written by Prof. John $R$. Commons in an artiele contributed to the Intercollegiate Magazine in 1909, "Utilitarianism Is the Demoeracy of Idealism."

It is this inexplicable idealism in the midst of the practical, the marriage of the imagination with modern applied science, the secularizing of the mind and the spirit, and the bringing out of dreams into the light of common day, that distinguishes present-day America. No other country by loeation or tradition has been so condueive to the draw- 
ing out of a useful idealism, or to making the mystic and the scholar practical and serviceable to the community. The vast distribution of wealth, the marvels of scientific exploration and industry, surpassing the wonders of the Egyptians, the strain of the Puritan, all set in an atmosphere of democratic obligation and coöperation, have furnished an alluring and an enchanting field for the development of a quality of idealism heretofore uncommon among men.

Strange as it may seem, it is in the person of the American business man, practical, level-headed, "all business," that this current of the ideal is clearly, often most clearly, seen. His big-heartedness is often in proportion to his blunt directness. Get a bit below the surface and you will find frequently a nature steeped in sentiment. "We do two things exceedingly well," says George Barr McCutcheon, "we dream and we perform." At the call of distress, either at home or abroad, his purse-strings are loosened with a prodigality that marks the fanatic. In his lusiness office he may be as austere as the statue of Memnon, but in his home or in the company of his friends he is as full of idealistic feeling and often of romanticism as the East Indian schoolboy.

The average American man of affairs, as soon as he gets past the persiflage of group conversation to his heart-toheart talk with you in quiet, will lead you to the little holy of holies of his own personal ideals, to some fine worthwhile issue, without which, notwithstanding his dollars, his ships, his industries, and his automobiles, he would be poor indeed.

Among the firms looking toward foreign trade is sometimes found the state of affairs in which an export manager possessed of these broad ideals of humanity and vision is tied to a narrow-minded manufacturer whose standards and methods apply only to a local situation. The only sensible way for such a manufacturer is to secure an export manager with experience and ability along the above lines and then trust him to develop the business. 
There is involved in the exporting manufacturer's business, or there should be, a strain of solemn responsibility to thousands and tens of thousands of people who need and may use his products. The man who wins in a worthwhile way in this line must have some eonception of himself as a great, practical missionary of trade. He goes out through his men and his methods to take a place on the farflung battle line of commerce to carry the evidences of American human achievement the world around. If he is a man of the right caliber and possessed of proper ideals, he will go to foreign nations leaving his preconceived narrow prejudices at home, being willing to be all things to all men, in order that he may succeed, not only in making money, but at the same time in carrying the spirit of the United States, the spirit of democracy, the "square deal," and legitimate achievement to the ends of the earth. A large percentage of the successes in foreign trading resides in a happy condition in which the manufacturer and his export manager see eye to eye in a broad-spirited, human policy, a policy based not entirely upon selfish considerations or money, but depending for its success as well upon broad lines of reciprocal coöperation and a universal belief in the general good intentions of the human race whereever it is encountered. 


\section{CHAPTER III}

\section{FOREIGN SALESMANSHIP AS A CAREER}

I respect the man who knows distinctly what he wishes. The greater part of all the mischief in the world arises from the fact that men do not sufficiently understand their own aims. They have undertaken to build a tower and spend no more labor on the foundation than would be necessary to erect a hut.-Goethe.

New occasions teach new duties; they open doors for new careers. It has been true always that the man who ean sell something is a success in life. Every one is engaged directly or indirectly in salesmanship. It is one of the elementary callings. The next decade will give this business of selling a new standing and a new scope, as American salesmen go forth to other lands to sell their goods, their brains, their country's good will, and their own trained services.

To be a suceessful salesman of American commodities in foreign lands is something over and in addition to being a successful seller of goods at home. It is something more than being a "hustler," or a "druminer," or a "commercial traveler," or a "live wire." It is something more than having the ability of "working off" goods.

Foreign salesmanship requires for its successful operation something even beyond a "self-made" man, fine and praiseworthy as such a man is rightfully estimated to be. Mr. Lincoln's observation may be remembered concerning a self-made man, who, he averred, was "too often in love with his maker." We believe it was Oliver Wendell Holmes who said that he liked a self-made man, but for 
steady association preferred a man in whom civilized arts and world culture had a hand in the making. In this respeet, Mr. Holmes was in line with the demand of the Latin, the Oriental, and in many eases with the eolonizing and commercial Britisher and European. In other words, foreign salesmanship means virtually all of the abilities and aecomplishments of the lome salesman-plus. This "plus" is the vital eonsideration which we wish to emphasize particularly for the consideration of all those who expeet to be the representatives of their nation in this new period of Ameriean overseas trade.

Mr. W. C. Shaw, the head of a large jewelry firm in Washington, D. C., is quoted as saying:

The thing which most salesmen do not realize is that the amount of goods a man sells depends to a very great extent upon his interest in them, his knowledge about them, and his imagination concerning his goods and the customer.

When you gather these three traits together in one man in a rightful, proportionate way, there is quite likely to result the personality of a suceessful salesman either at home or abroad. Yet, the applieation of these qualifieations when applied to eommeree amongst foreigners, requires earnest thoughtfulness, and brings out the individual capacity for adjustment and that peculiar inner sense of understanding, which belong alike to a diplomat and to a commercial agent working in other lands.

The first essential of a foreign salesman is a broad and clear knowledge of the field and the facts in the realm of his prescribed activity.

Any problem can be solved [deciared Herbert Hoover], if you have the accurate data. Make sure you have the facts; then you can command any sitnation if you work at it hard enough and long enough.

Success in the foreign field cornes to the man who linows; to the man who grows mentally as well as in practical 
experience; to the man who sets no limits to his ideal of achievement in the realms of all-around education and the broadening of his knowledge. This knowledge on the part of a foreign salesman includes naturally a familiarity with snch fundamental essentials as prices of his goods, methods of shipment, packing and financing, the rules and policy of his house, and the comparative value of his products as related to possible competitors. We take for granted that no manufacturer or firm would think of sending out of the country a man who had not grasped the rudimentary essentials for selling his goods at home. Foreign salesmanship, however, demands a super-salesman, one whose intelligence and training enable him to get beyond his specialty to the country where he is selling and to the people with whom he trades. He must not only know the people and the lands which he visits, but he must be possessed of that sympathetic interest and imagination enabling him to see needs and possibilities from the point of view and out of the eyes of his prospective buyers.

Here is a work and a veritable career for a man who is willing to study and to acquire more than the average knowledge about his product and his new world of activity. An American who breaks himself out, so to speak, into such new spheres of activities as are open to him now in Latin America, in Central or Southern Africa, in India or in Russia, in China or Japan, will find himself in need of education and social advantages far beyond those of the usual salesman at home. He may not use in every sale his exceptional knowledge, but this knowledge is always present with him as a background for his judgment, giving him perspective and confidence, without which he is doomed to the ranks of mediocrity in any attempt to compete with European salesmen abroad.

Something like a year ago, a young man came to me saying that he expected to be sent to China to sell motor trucks. He had been successful in selling these in the United States, but China was different. He recognized the limitations of his knowledge regarding his new field 
and among questions which he set himself to answer were the following:

What about the Chinese-how have they been accustomed to transport their goods? What kind of roads are there in China? What are the facts concerning long hauls and short hauls, city traffe, country traffe and present systems of delivery? What of transportation in general? How about the possibility of training Chinese to drive motor trucks? What eompetition is there, or is there likely to be in this line? Judging from the knowledge of the eivilization and characteristies of the Chinese, as well as from the experience of successful foreign activities in this great country, what would be naturally the easiest approach to the Chinese business man?

This young man spent his evenings for more than a year studying these questions. He haunted libraries and he read books without number, not only relative to technical matters and eonstruction of motor trueks, but all of the available data in relation to the eountry in which there was a possibility of his spending many years of his life. The customs of the people, their religion, their literature, their education, their arts, and their shop-keeping propensities-all of these subjects were grist for his mill. $\mathrm{He}$ talked with Chinese students in our eolleges here in the United States; he talked with laundry-men; he talked with exporters, Chinese bankers and with Ameriean traveling agents who had spent years in the eountry; he examined pictures in magazines and art galleries; he gave particular attention to the subjeet of his competitors' lines already having a sale in China; he found out the names of firms who had purchased them; he eonvineed himself that he knew almost as much about his competitors' trueks as he did about his own; he studied the Government of China and the history of the British, the French, the Japanese and the Ameriean politieal and trade relationships to this country. He studied Chinese exehange; the shipping laws; the use of the eompradore. He even became something of a specialist in pidgin-English by conversing with sailors 
who had enlarged their vocabularies in the port cities of the erstwhile Manchu Empirc. When I met him after a year of this kind of training, the prospective foreign salesman was in reality something of a specialist upon his subject. He seemed to exude China at every pore. It took only a few moves of conversation to get him started on China and motor trucks.

This man is going to be a super-salesman and we foresee his success, because he is going to know his subject in its broad relationships. He is going to be in a position to teach the Chinese something even about themselves and the possibilities of their commercial enterprises. He is climbing rapidly on the higher rungs of the foreign salesmanship ladder-the ladder of comprehensive knowledge. If he does not sell motor trucks he will sell something else in China, and we predict that he will succeed because he has taken pains to know.

Such knowledge in a foreign seller of American goods is important, moreover, because both the manufacturer and the business man at home, as well as buyers abroad, are accustomed to depend upon such a salesman for advice as well as for knowledge abont goods and national conditions. These pioneering men of "the sale" are judges of conditions industrially, socially, and politically, in the lands where they are called upon to serve and all these conditions are vital to the activities and prospects of trade. These men are truly pioneers, carrying their firm's goods often for the first time to untried markets. The home firm must depend upon their judgment born of knowledge and intelligent measurement of markets, and these traits are usually determining factors in the success or failure of the house in foreign lands.

The future of these foreign salesmen, their earning power, their eareers, depend largely upon their superknowledge, and their salesmanship ability is quite certain to be interwoven with an exceutive and administrative faculty as they grow in knowledge and experience. The big foreign salesman becomes the big executive of the 


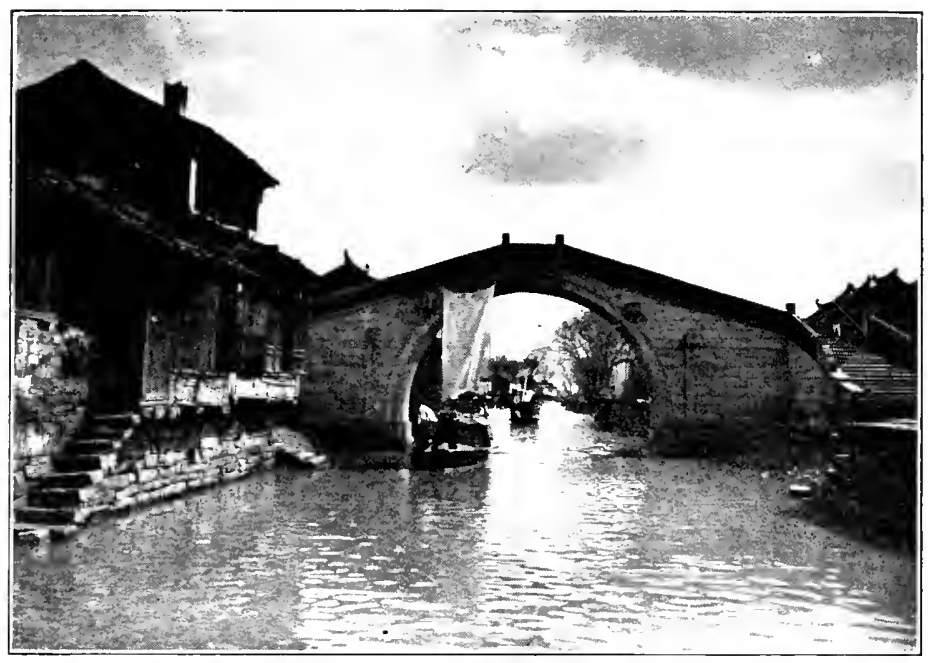

ALONG THE CANALS OF CHINA WHERE MODERN COMMERCIAL TRAFFIC IS RAPIDLY TAKING THE PLACE OF THE OLD, LEISURELY EXISTENCE.

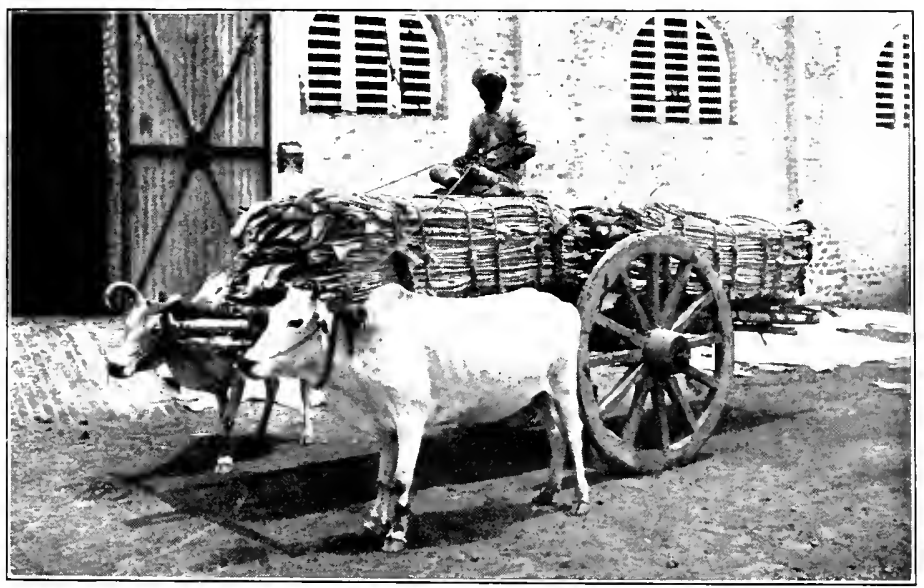

TRANSPORTATION UF HIDES IN THE STREET' OF CALCUTTA, INDIA. CART LOADED READY TO MOVE UFF TO DOCKS. 


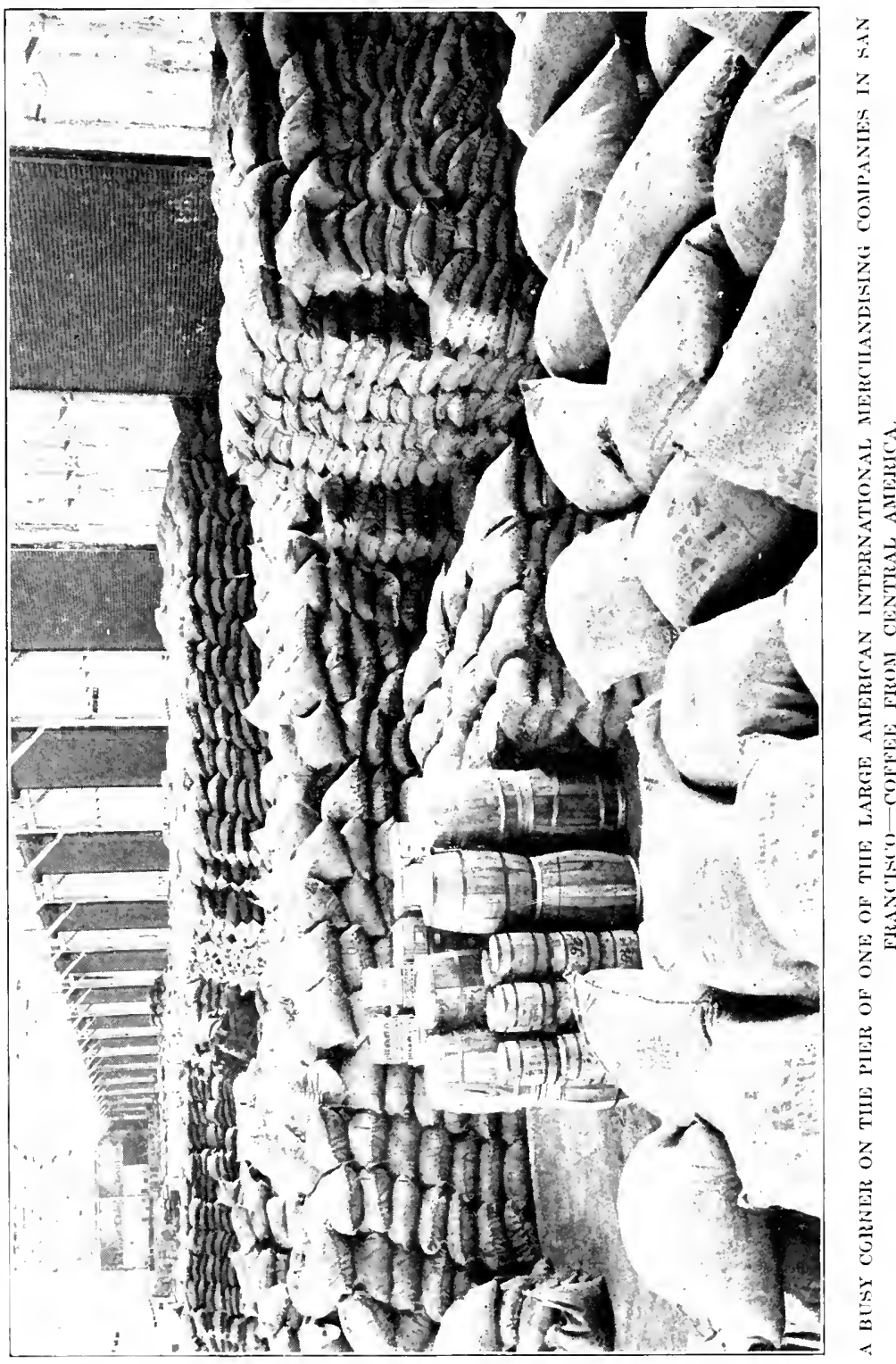


firm's branch house, while the narrow gauge salesman who has failed to see his chance is called home, often under a cloud of failure.

"Knowledge is power," and never more powerful than when applied to the selling of American products in foreign lands.

Another realm in which the foreign salesman must be equipped is that of eurrent trade events and financial conditions both at home and abroad. For example, the man who is sent out from his home office in the years of 1920-1921 to Central or South America, or to some European or Asiatic post, would be greatly handicapped if he did not understand thoroughly the question of exchange and credits. He must keep up on these facts through the newspapers and special Government and Board of Trade reports. He should be in touch with the Federal Reserve Board's action relative to banks in the curtailing of loans for speculative purposes. He should be familiar with such measures as the Webb Bill, the Edge Act, the Seaman's Act, the Jones Bill, tariff measures and cable legislation and he should know the latest facts relative to the United States Shipping Board's policy concerning overseas carriers. Current labor questions should be known by him in order that he may compute their effect upon manufacturers and the sale of his products abroad. If he is selling steel, he should know that the stecl strike (1920) curtailed production probably $3,000,000$ tons and that it was six months before the industry caught up with its orders.

This man should not go out without having a general idea of the railroad situation in this country, for transportation at home, possible rates and promptness of shipment relate directly to his success or failure in deliveries of his goods sold to foreign countries. Naturally, he would be asked, especially by Americans abroad, regarding income and excess profits taxes, as well as the results of such meetings as the National Foreign Trade Council conventions, Pan-American Financial conferences, findings of Interstate Commerce, and the Federal Trade Commission's 
resoutions. He should know conditions relative to political radicals in the United States as they affect labor and unrest; market conditions as to coal; cable conditions; as well as knowing influences affecting commodities, such as oil used increasingly as fuel for ships. All of these subjects are facts germane to his business of sclling and 'dcliveries.

It is taken for granted that if the man is going to a Spanish or French speaking country he has become suffciently familiar with the languages of these countries to secure portions of his current information regarding these lands from the foreign representatives in Consulates and in various foreign organizations here at home. In other words, the foreign salesman should be so eapable through his industrious and thoughtful contact with current, financial and industrial affairs, that he may be able to form eorrect, and as is often required, rapid decisions when out of touch with the home office and when often important undertakings depend solely upon his judyment and comprehensive business knowledge.

In the foreign field even more strictly than at home the general character and honesty of the representative of an American firm are inevitable factors of success or failure. There has been all too much eriticism abroad by foreign competitors against our foreign salesmen in certain parts of the world who have been sent out without proper selection or equipment by some of our American houses. These have been called "fly by night" concerns, and in many cases it has not been realized that the "repeat orders" are the important elements in building up foreign American trade and that these orders never materialize if the character and honesty of the firm through the personality of the salesman is questionable by reason of the first contact. So important is this matter, to the Latin American countries for example, that committees of business men were formed in Argentina previous to the organization of the present effective Argentine-American Chamber of Commerce for the purpose of keeping surveillance over American busi- 
ness houses and agents doing business in that country, guarding against infraction of aecepted rules and regula. tions of intertrade between the two nations. This matter was considered at length in the second Pan-American Conference.

It is particularly true in Latin America, where personal likes and dislikes are frequently determining factors in trade relations, that the foreign salesman should be the kind of man whose word is as good as his bond and in whom the confidence of the Latin American can be placed, not only for one year, but for the years to come. Soutb Americans are particularly averse to doing business with new salesmen, and if a man has proved his worth and has once gained confidence they would much prefer to deal with such a man than to change to another firm, even though there might be a prospect of certain economic advantages.

There is hardly a characteristic of the foreign salesman more valuable than the reputation of telling the strict truth regarding his goods and his house, and thereby gaining in the long run a confidence that is one of the most valuable assets in foreign commerce. That honesty proves to be the best poliey among Americans doing business abroad, was suggested from a somewhat curious angle in an incident told me while I was in Brazil, regarding a visit of the President with his staff to one of the foreign enterprises. The Brazilian President had seen a certain change which it was necessary to make in a power plant in order to conform to Brazilian law. He brought it to the attention of the manager who happened to be an American, and the manager said that he would attend to it. Some time afterwards the President called his secretary and asked him if his order had been carried out, to which the Brazilian Secretary replied:

Why, it must have been, because the manager said it would be done, and Americans always tell the truth. 
The President thought for several minutes and then said:

Yes, the Amcricans seem to tell the truth, because they wish to save time and time is of great importance to them. They have learned that the man who does not tell the truth loses a lot of time becanse he is sure sooner or later to be found out and be obliged to make explanations and thereby lose more valuable time than he would if he had told the truth in the first place.

We have some doubts as to the correctness of the Brazilian psychology concerning the American character in this case, but he certainly was right in his conclusion that the foreigner abroad must somehow build up a reputation for truth telling if he expects to succeed.

It is essential also to lay emphasis upon the attention that the foreign salesman must give to the maintenance of his character when far from home and in an alien land, surrounded by new conditions and often by customs that make it easy to depart from habits of life which are easily followed at home. Those who have traveled abroad need not be told of the wrecks of American manhood that have occurred in certain foreign cities, simply because the man has lacked the strength and power of will to maintain his moral integrity abroad. The foreign salesman who indulges in habits of gambling or feels that he must fall into the social eustoms practiced by some of the foreign business men frequenting the Far East or West Africa for example during the last generation, is undercutting not only his usefulness, but his career. The American foreign salesman who goes out to other lands must guard rigidly his own habits in relation to the drink problem lest the natural tendency of human nature carry him to excess. As truly as the Ambassador, the Foreign Minister, the Consul, or the Commercial Attache carry in their personalities and acts the good name of the United States, so does the foreign salesman hold in his keeping the national good will and reputation of his country. In the field of foreign trade in the next twenty-five years the United States will be tested as perhans never before in its history, and in no 
wise more truly than in the maintenance of those ideals of probity, business integrity and unselfish ambition which have made our country conspicuous among nations during the war.

It is well for salesmen to remember that, in offering goods, the salesman sells himself first and if he is the real thing, his product and house will not lack acceptance in foreign communities.

Granted that this salesman plus, who in Kipling's phrase "goes up to occupy" his rightful place in the sun, possesses a broad knowledge and adds to it the ability to sell together with moral integrity, he has yet to possess or to acquire a pearl of great price for a foreign salesman, namely-manners.

An unimportant and trivial matter, you say, but it is in these so-called unimportant and small adjustments that men succeed or fail abroad as at home. George J. Whelan who founded and built up a company that operates 1300 stores in 400 eities (United Cigar Stores) says:

We found out that people dislike steps, so we put all our stores on a level with the street; one step can be counted on to lose just one customer a day and every additional step just so many more. We found in this business that it is necessary to make things as easy and as pleasant as possible.

In this connection it might be noted that one of the large cigar store men reported "a decided increase in business" after they had established the policy on the part of every one of their employees of saying "thank you" to their customers after a purchase.

This emphasis upon the amenities of life as required by the foreign salesman is vital. What enterprise requires more generally the right attributes for first impress than the trade of the man who sells goods and service to foreigners, whose confidence first of all must be won? For him the New England schoolmaster's verse to his graduates is significant :

I send you forth. Go, lose or conquer as you can, But if you fall or if you rise, be each, pray God, a gentleman. 
The man who goes forth to other lands with what physicians call "megalocephalous," thinking to "put it over" by his rough and ready aggressiveness, despising the social graces, will come home shortly a sadder but a wiser man.

The foreign seller will be called upon to mateh his wits and personality against the men who have inherited ancient and cultured eivilizations, eivilizations in existence centuries before our own country was discovered. He will be called upon to do business with men who are often more broadly intelligent, more cosmopolitan, more urbane, more civil, more ceremonious and more conseious of human dignity than are we as a rule here in this new virile land of youth and aggressive achievement.

A high-class (hinese, commenting to me upon the acts of a brusque, loud-spoken foreign salesman who had just visited him, said :

It takes centuries to breed culture. Your western countries are yet too young to attain it. We should not expect too mucb from you.

In South America some years ago we were somewhat amused at the position of a Latin American who was chairman of a reception committee to receive a delegation of business men from the United States. He was uncertain as to whether certain members of this delegation would know how to conduct themselves at a reception composed of some of the prominent officials of his country, since, he said in explanation:

I infer, judging from certain business men whom I have met in the North, that social customs and manners of the drawing room are considered too trivial for the American business man to bother with; yet with us, they are very important as they reveal the soul and breeding of the individual.

If there is any "uneomfortable work of. God" to a eultured Latin or. Oriental, it is an effusivc, peppery, pushing and aggressively patriotic, ill-mannered man or woman. 
No amount of "effieieney" can make up for the lack of taste in dress or deportment of a representative of an American house abroad. It is all very well to be patriotic and work off sentiments about "God's Country" while here at home, but the man who follows this eustom abroad is usually spoken of as "Yankee," or "Gringo," or "Pork Packer," or "Bounder," or "Ameriean Millionaire," according to the latitude and longitude of the earth he happens to be in. Usually when these terms are used relative to an American they are not intended to be eomplimentary.

We are inclined to believe from our observations that the foreign salesman prejudices his eustomer against him by too much talk. It is well to remember the old proverb of Josh Billings, who said:

A bore is a man who talks so much about himself that you can't talk about yourself.

One of the most successful foreign salesman whom I know is a very good listener. He has extremely quiet manners and never interrupts or gives his prospective buyer a feeling that he does not respect highly his opinions and ideas. He wins by his reserve rather than by his pushing ways.

In view of the extreme importance of this subject of deportment, as related to foreign salesmanship, we are tempted to add a decalogue of "don'ts":

\section{A Foreign Salesman's Decalogue:}

First: Thou shalt not address thy prospeetive purchaser in what is to him an alien tongue! (This is to lose your ease before you begin to plead it.)

Second: Thou shalt not yell at thy eustomer as though you were in a boiler factory! (Foreigners are not usually deaf.)

Third: Thou shalt not try to hustle your eustomer be he Latin, Briton, Oriental, Spanish or Portuguese-Ameri- 
ean! (This is one of the unpardonable sins of the foreign salesman.)

Fourth: Thou shalt not lie about thy goods, or thy firm, or thy income, or thy personal achievements! (Emerson said, "What you are makes so much noise that I ean't hear what you say.')

Fifth: Thou shalt not wear clothes that herald thy approach by reason of the loudness of their color, neither shalt thou wear thy hat on thy head nor thy eigar in thy mouth when entering a foreigner's office!

Sixth: Thou shalt not wax aggressively patriotic in the presence of a foreigner, nor shalt thou draw invidious comparisons between Paris and New York or between Buenos Aires and Buffalo!

Scventh: Thou shalt not eall Latin Americans "thinlyveiled Indians," or Orientals "yellow men," or East Indians, "Eurasians," or Italians, "Wops," or in any wiso deal expansively with the color of thy eustomers' skins! (Remember that there is no color line in foreign trade.)

Eighth: Thou shalt not vaunt thyself or be puffed up? (You ean't beat the Englishman in conceit-so why try to compete with him?)

Ninth: Thou shalt not bear false witness against thy competitor!

Tenth: Thou shalt not eriticise adversely thy eustomer's morals, thy customer's clothes, his amusements, his food, his house, nor his women, nor his trade methods, nor his religion! (Mark Twain said that the chief irreverence is irreverence for another man's gods.)

If this were not a decalogue we would be tempted to add as a rider to these rules, an eleventh positive command, namely: Thou Shalt Put Thyself in Thy Customer's Place! 


\section{CHAPTER IV}

\section{EXPORT ADVERTISING: ITS NECESSITY AND HOW ACCOMPLISED}

When the American uses the word "advertising," he understands with peculiar exactness what he means. Advertising is in the American domain-it is a modium in which he is at home. While it may not be said that Americans originated advertising, nevertheless it is true that no race of men have been more inventive or more suceessful in this field.

The American phrase, "It pays to Advertise," has become a modern business proverb. We believe in it and we seem capable of endless variation in our genius for visualizing in ink, in pietures and in wood and stone that whieh we wish to impress upon the thought and imagination of men.

Advertising has become an art and a profession in the United States. It is estimated that nearly a half billion of dollars are spent yearly in a myriad of ways to tell to the public the story or the dream of a man who has something to sell. By this comparatively new vocation many thousands of American men and women gain a livelihood. Whatever we may be able to learn from the old World-and that is much-we do not cross the seas to get incentive or examples of how to advertise in America.

But here, as in many another case, our unquestioned success at home may prove a stumbling block when we endeavor to transfer our native success to forcign fields. The war already has taught us that one nation's method of doing things successfully at home does not prove success 
abroad, however much we may think these methods ought to do so. The Englishman with his negative bent of mind and mental reserve, the emotional and artistic tempered Latin, the indirect and meditative Oriental do not look at the world and things as we do. They cannot and never will, because racially and traditionally for centuries upon centuries their starting points have been different. To fool ourselves about this point is frequently the first and fatal mistake of the advertiser abroad.

It may be true that down in the depths of their souls all men everywhere are kin, but when we strive, either by Leagues of Nations or Leagues of Advertisers to fit ono instrumentality to suit all races, we are confronted with a task more diffienlt than were the seven labors of Hercules. In advertising, as in politics, "When in Rome we must do as the Romans do," and the same applies to Valparaiso, Osaka, Calcutta, Barcelona, or Peking.

Domestic advertising and export advertising are two different things. It may be of help to consider some of the general prineiples that apply to advertising-American advertising particularly-when it goes out to win the world for American products and American cnterprises.

There are different ways taken by differcnt nations to exhibit their racial and historical traits, and these differences must he known by the suceessful advertiser. If the advertising manager does not have the time or the inclination to find out these differences he should get the advice of some thoughtful and astute export manager or agent who has lived or traveled extensively in the country for which advertising is being prepared. For example, wo know of a certain manufacturer who poured thousands of dollars down a pipe that had no end, charging it up to "Export Expense," before he learned that the whole texture of his argument was wrong. He was advertising a product in a country dominated by British sentiment, using glaring statistics and playing up vast income figures and material wealth of the United States-things which are anathema to the usual British mind. Make no mistake- 
no nationals are indifferent to economic success! Gold is almighty the world around and no disaster is more tragie than financial ineompetence. Yet it is a fact that eertain Europeans still think of us chiefly as "Pork Packers" and "People of the Dollar Mark," while "Americans" in Japan and other plazes in the East are synonymous with "Millionaires."

These very nations are not averse, however, to getting our dollars and their old world ideals are utterly dependent upon building securely an economic and industrial foundation. The difference is one of method and often of expression and restraint in playing up facts. This point was brought out in a certain experience in the Far East. We were traveling on a small steamer between Korea and Port Arthur on the Yellow Sea. Our companions wero a Seotehman and his son, both of whom had been rather jocosely picturing Americans as somewhat too eager in their personal eonversation to emplasize how much they were worth and to play up the material side of everything. Naturally we were upholding our eountry as best we could by the argument of a young nation developing first its natural resources, building first the strong economic bases of its civilization, and then passing on to the flowering of literary, cultural and artistic pursuits. It almost seemed that we had produced an argument of some effect, even upon the Scottisl mind, when from the midst of a Cook party at the other end of the dining saloon a shrill Yankee voice picred the air with the question, "Say Bill, what does a porterhouse stcak cost at the Holland House?" The incident was such a manifest point for our opponent that we felt inclined to drop the subject for the time being.

In South America the dignity of advertisement is more likely to win deserved attention. There is not shown there the admiration for yellow and sensational advertising existing in some countries. One of the largest newspapers in Latin America makes its advertising display in a chaste, dignified frame less than two feet square in front of its large building. To plaster over the side of the beautiful 
building glowing placards with electric letters a foot high would be as inconceivable as it would seem to be devoid of taste; and as Emile Boutroux, the distinguished member of the French Academy, once said to me, when I asked the eharacteristic of the French people:

The Latins place a great emphasis on good taste.

A prominent Peruvian citizen led me out one day in the city of Lima near the eity square and stopped beside a high wall on one side of the old eathedral where some enterprising and pushing countryman of mine had purchased space upon which to place a life-size portrait of the familiar, undying face of Lydia E. Pinkham-with her world-famed vegetable compound bountifully described. The Peruvian did not actually accuse us of poor taste in advertising, but his look said:

By the bones of Pizarro which lie in dust less than fifty feet away in the great dignified church of our Spanish ancestors, how could any one be so devoid of taste!

If the advertising agent who placed that sign in that particular place had taken pains to confer with almost any American living in Lima, he would have been saved the mistake of creating an advertising chasm almost too great for any sales argument to bridge.

Hugh Kahler has defined advertising as

A force which makes one's goods less apt to be refused when offered.

The study of surface differences for the advertiser to consider in foreign export exploitation includes such questions as the following:

1. Does sensational advertising or quiet methods prove most desirable to those whose attention and good-will would be eaptured? 
2. What is the prevailing historical tradition of these people and how does it differ from that of my own land?

3. What is the religion of these people and what are their sensitive nerves?

4. Do these people like Amerieans? If not, how can we word our advertising so as to least offend?

5. What local events afford the most opportune peg upon which to hang the advertisement?

Another extremely important means of presenting export enterprises to people in other countries is through the medium of the personal letter. Doubtless the salesman in his personality and ability of presentation provides the best means of advertising which any firm possesses, but nevertheless, it is possible to transfer much of this power or personal interest and individuality through the typewritten word. While correspondence in general is an art, as an aid to export advertising it is a fine art. It is more personal and more intimate than the printed advertising word and for this reason it should be more carefully studied. A few lapses in a letter have spoiled many a good prospective contract. A firm engaged in selling goods ahroad should have a definite policy about its correspondence as elear eut as any other plan for the promotion of sales.

I heard recently of a firm which had established a kind of school or conference for the training of those whose duty it was to correspond with clients or prospective purchasers in foreign countries. In this way it became possible for each letter sent out to reflect the spirit of the house and obviated the danger of cross purposes which often appear in correspondence of different departments in the same establishment.

This colrespondence should uniformly reflect courtesy, good will, clearness and accurary, not forgetting the use of terms in the address and at the end of the letter which are familiarly used by the people in the country to which 
the correspondence is addressed. The matter of clearness eannot be over-emphasized in letter writing to people abroad. John Locke onee said that the most important essential of any suceessful man consists in "clear ideas." In the transference of thought between peoples speaking different tongues and inheriting different traditions, this is even more vital than in correspondence at home.

We think of an instance in which it cost a house several hundred dollars in eables and other expense in filling an order, simply because the original letter containing the request was indefinitely worded and could be interpreted in one, two, or three ways. Carelessness and stupidity are inexcusable attendants of any business and partieularly is this true in letters where face to face explanations cannot be made.

The consideration of the point of view of the people to whom one writes is also of vital importanee in export letters. The Orientals as well as Latins are not inelined to be impressed with the short, erisp and often abrupt notes of the American or English business man. A certain amount of polish and ceremony is as necessary in a business letter to the Oriental or to the Latin American, as it would be in personal address. To ignore this through any obstinate prejudice regarding our own ways of doing things is to be shortsighted and is usually a confession of ignorance not easily overlooked by a person of another nation, who is inclined to study these small points with eare.

Wherever possible the reader's language should be used and as far as possible the writer should mentally put himself in the place of the person he is addressing.

Walter F. Wyman, in his book entitled Direct Exporting, cites a sales letter addressed to a prominent Calcutta merehant, which began:

Bill Jones of Kalamazoo made $\$ 1800$ in one month with our patent back-actioned potato peeler. Can't you do as well as Bill?

Mr. Wyman suggests that the situation be reversed and 
Mr. Manufacturer in St. Louis receives from Calcutta some such letter as this:

Kawa Dhurur of Thalra Patan made Rs. 3600 in one purulia. Can't you sell as many laces as Kawa?

Naturally such letters as these, and they are not infrequent, received on either side of the export and import lines, are useless except for joke-making purposes.

Mr. Wyman in this book also suggests ten points of distinction which characterize a successful letter written by a New York man to a Melbourne firm, showing ten "distinguishing trifles" very important for successful export advertising in letters to British clients :

Messrs. Hilliard Bros \& Co., Ltd.,

24th January, 1919.

716 Collins Street,

Melbourne, Vic.

DeAR SIRS:

I would appreciate the favor of your examination of the samples of Meteor lockets, which are going on, duty paid, by this post.

If you will show these to some of your customers who enjoy good craftsmanship, I would be doubly grateful for their comments.

It has not been my good fortune to visit Melbourne since 1908, and in my five trips I never chanced to represent any jewelry lines. This I certainly regret now, for with your many years of experience in Melbourne in the jewelry line, a personal aequaintance would make me feel that I was not imposing on your good nature in my queries.

It would naturally be a pleasure to me to find that the lockets will appeal to you as something worth selling, and the attached sheet will give prices, terms and all shipping details, arranged to show you the per cent laid down on several other lines as well.

Are you by any chance allied with Messrs. Hilliard \& Sons, Ltd., of Glasgow? If so, possibly advantageous shipping arrangements could be made through my Glasgow connections, Yours faithfully,

JAMES M. JONES 
The ten points of distinetion:

1. 24th January, 1919.

2. Messrs. (too often omitted).

3. Favor.

4. By this post.

5. Show.

6. Slow the per cent laid down.

7. Glasgow (not Glasgow, Scotland).

8. Yours faithfully.

9. Copied.

10. The fullow cony which went to Messrs. Hilliard \& Co., Ltd., on the next boat.

One of our Ancrican manufacturers was eriticised by a Liverpool importer in these words:

Those Yankees are in so much of a hurry that their goods cannot always be just right. They always blo' the signature to typed letters.

The motto of one of the leading American newspaper editors may well be kept in mind in this matter of advertising through correspondence- "Accuracy, Terseness, Accuracy." It is extremely important to specify rather than to assume in eorrespondenee. A good motto is not to tako anything for granted, but to make the point so clear that, as Dr. Lyman Alubott once said:

Even my Aunt Mary ean understand what I am saying.

Many correspondents presenting to foreign purchasers American-made goods are inclined to think more of their competitors than they do of accurately describing their product. As a matter of fact the foreign buyer may never have heard of the article before and emphasis should not be laid upon a minor point of advantage over some rival article-a mistake frequently made.

It goes almost without saying that the more a person can reveal some distinct personality in his letter the more 
effective it will become. We know of a man who in writing to Eastern native firms has adopted the use of word pietures, so common among Orientals in presenting their ideas. His letters to an Oriental and to an Oceidental are as different as two things could possibly be. By travel and study he has caught the spirit of difference between nationals and has had the imagination and tact to adapt himself to this difference. It is hard to lay down rules as to the manner in which this adjustment should be made by any particular individual, but unless the exporter and the manufacturer by study and thought ean discover a way for himself of transferring his thought so that it goes with emphasis and meaning to the mind of his prospective elient, he will have failed in a vital point of foreign trade.

As an advertising medium the IIouse Organ has grown apace during the past decade. It is estimated that at present there are approximately two thousand house organs published in the United States. These magazines vary widely, some being aimed particularly to develop the morale and esprit de corps of the organization itself by giving knowledge of the work, while others are aimed directly at the sales organization and have as an object the increasing of the firm's profits. Some of these magazines are edited with care while others are left to the odds and ends of time which may possibly be given to them by an export manager. For large business organizations engaged in trade abroad some such advertising medium is inevitable as a means of cementing the company and focusing attention upon the outstanding policies and facilities for handling products. This subject is treated in detail in another section, but it may be important to add here that its effectiveness as an advertising medium depends largely upon the way in which the officers and executives of any given firm accept it as a definite means of advertising and propaganda, and utilize it for their particular specialties.

More and more firms engaged in foreign trade are placing emphasis on local advertising in foreign markets. This 
is especially desirable when the firm has an agent or a special office director who understands not only the language of the people, but their general attitude.

There is little doubt but that the export policy of export firms will include inereasingly during the next few years, the planning of systematic and effeetive advertising from local foreign centers in various languages, using as a background the knowledge of the particular locality possessed by local representatives of Ameriean firms.

In this entire matter as in all trading with foreign nations, the spirit and the personality of the salesman or foreign representative is the central issue. In export advertising the manufaeturer or the salesman sells himsclf; his absolute honesty, his straightforwardness, the desire to live and let live, and his faculty of sympathetic imagination, if he possesses these traits, will find means of expression in every form of presentation which he makes of his goods, either at home or abroad. The exporter's ideal is eertain, sooner or later, to color and to determine the success of his advertising propaganda.

The value of advertising is based upon enfidence in the advertiser. The client is always trying to visualize behind the advertisement the motive and the character of the seller or the exporter. That export advertising which ean combine up-to-date and earefully adjusted methods with a genuine, whole-hearted purpose on the part of the exporter will not fail for long to secure broad and enlarging markets. 


\section{CHAPTER V}

\section{TRAINING FOR FOREIGN COMMERCE}

The world is founded on thoughts and ideas, not on cotton and iron.-Emerson.

It is a national Ameriean eharaeteristie to do everything exeessively and not to do anything by halves. Of late this trait of enthusiastic acceptance of opportunity in forcign commerce has eaptured a considerable and growing portion of our population. Our youth returned from Franee with a new vision of world races and world possibilities. They besieged our great export, shipping and banking houses for positions that wonld align them with activities abroad. The sea and ships have canght the imagination of thousands of young Americans for the first time and South America, South Afriea, China and East India already eontain men who have been sent freshly forth during the past two years by American firms to represent them in foreign offices. Never has there been such a demand for men or for information regarding overseas trade as since the European war, never so many questions asked relative to opportunities abroad. Men eome to our foreign trade houses from schools, from the professions, doetors, lawyers, preachers, writers, and even women, asking for places in this new activity that reaches around the world.

There is evident reason for the belief of these men, in our country's opportunity in trade overseas; for recent statistics gathered by the Department of Commeree at Washington show that, while before the war the United States ranked second to the United Kingdom as an export 
nation, we had in 1920 the largest foreign commerce of any nation in the world. With our expanding resources and with the new alertuess on the part of our business men relative to overseas trade in general, there is no reason why foreign commerce as a vocation should not open one of the most fascinating and luerative fields for American youth.

An instance of this natural sweep of opportunity is given in the fact that we in the United States have over one-half the known coal of the world and two-thirds the world's cotton. While we have only 7 per cent of the world's land and only s per cent of the world's population, our production of the world's supply of basic raw materials and grains is 50 per cent. We produce approximately 25 per cent of the world's wheat, 40 per cent of the world's lead, 50 per cent of the wnrld's zine, 50 per cent of the world's coal, 60 per cent of the world's aluminum, 60 per cent of the world's copper, 6.5 per cent of the world's cotton, 65 per cent of the world's oil and 75 per cent of the world's corn.

Sinee we are unable to consume at home the total of these vast products, export trade is beeoming a neecsity for us and if we have the men properly trained to enter this open door we ought to be able to do the manufacturing and earrying of the foreign commerce for fully onehalf the world; but we must have men trained to operate our new ships and an ever-increasing flow of workers for shipping offices and shipyards, or else our American Merchant Marine becomos an economic danger rather than a great promise. We also must have men who will accept the opportunity for preparation in foreign banking and merchandising, if we expect to go out with success along the highways of world commerce.

For, after all, this game of trade with other nations is just beginning for us. It is to us largely a new game, and it is highly specialized. As a nation, we do not yet know the rules. Our competitors are seasoned traders with scores of years of experience behind them, and what is 
more vital, they feel the urge of necessity for seeking trade outside their own borders if they are to survive in the family of nations. There is no doubt that we, as a people, have the imagination, the energy, and the practical genius to enter into this competitive struggle for world markets, but, unless we give attention to our training, we shall eome off as badly as many an upstart trading house that began to seek markets during the war, all unprepared, and even yet is wondering why it lost its money and its time.

The Duke of Wellington said that the battles of England were won on the playing fields of Eton and Rugby where English youth were trained to play the game of life and to play it fair. Likewise, foreign trade, partially at least, is won at home before the men go forth. It is here that they must imbibe the elements of sucess which will enable them to "fall on their feet" amidst alien peoples and also to hold their own against the trade veterans who have weathered many a business battle on foreign shores.

First of all, let no one deceive himself into thinking that the characteristics that win in foreign trade are a kind of mysterious sleight-of-hand, something that goes along with learning Spanish or Chinese. Foreign trade is not an exercise in legerdemain. The fundamentals are the same traits that make a man succeed at home. It is the spirit of the man that wins quite as much as his knowledge of method. It is the quality of the man quite as much as the knowledge of export quotations that determine the risult.

One of the first necessities for a successful foreign trader is a wide vision. It is easier to do a big thing than a small thing, and the first essential is the man who can visualize an enterprise of great proportion. John Ruskin once said :

The greatest thing that any man can do in this world is to see something and then go and tell his rision in a plain way. 
The foreign trade business has no fixed horizon. It is written upon the skies as upon the seas; the airplanes and the ships are to be the carriers of food as well as of products in the next generation to the earth's farthest lands.

I know an American manufacturer who was able to visualize practically all the inhabitants of Asia using his carriages and rickshaws that he would make in a town in New Jersey. As a result to-day the American traveler rides in these American conveyances in nearly every country in the Orient.

World trade is not for the narrow visioned. It means a map of the world on one's desk. Beginnings may be small and slow, but the foundations must be laid, both in the mind of the manufacturer and his agents whom he inspires, for a structure of business world-wide in its reach.

Let a man feel that he is bracing himself against a world task; let him lay patiently and deeply the groundwork of his training and eonfidence, for it is here trading companies win or lose even at the beginning. The first principle of success is a world eyesight ; a short vision is suicide in foreign eommerce.

There is, furthermore, no realm of business in which perseverance and dogged determination, even despite many failures and losses, are more essential than in foreign commeree. The trader must add to a big vision, resolution. Nothing short of a cast-iron purpose will weather the vieissitudes eonsequent upon getting on with a new language, new customs, strange peoples, homesickness, unusual temptations and the onslaughts of his competitors. A man may be trained to a nicety in the regulation methods of trade, language, shipping rules, invoices and selling arguments, but, if he cannot brook failure and discouragement, let him not enter here! The need is not merely for able men, but it is always for determined men, men who are not afraid to work and who will "never say die."

Mr. Edison was asked once to define genius and he answered, "Two per cent inspiration and ninety-eight per 
cent perspiration." "It is dogged as does it," said Charles Darwin.

We met a man, a southern youth, in a flourishing town of South Brazil. He was the only American in the place. $\mathrm{He}$ had been trained in railroading in a good school of experience in the "States" and he knew how to manage an American railroad. In Brazil, however, with indifferent labor, with a strange climate, amid people whose manners and methods and laws were new to him and offered many obstructions, the railroad game took on different proportions. I watched him working at the complicated task in that section, of securing proper cars and trains to get a large shipment of Parana lumber from a sawmill on the edge of the jungle down to the seacoast. Being impressed with his efforts, I asked him what trait was most essential for a young American to possess who went railroading in South America. He thought a moment and then answered : "The grit to hang on." As I followed that man for scveral weeks through the forests and over the newly laid railway trails of Southern Brazil, watehed him adapt himself to foreign labor that included Hollanders, Portuguese, Hungarians, Swedes, Italians and Brazilians, always finding him personally on the job both night and day, restoring washouts on his roads, devising new lines, haggling with native officials for concessions, drinking mate with his laboring men in the jungle, foregoing comforts and spending wakeful nights figuring his way through difficult and well-nigh insurmountable problems, I bccame convinced that his key to the things that suceed in foreign lands was worth considering. I thought of Napoleon's famous dictum to his soldiers in his Alpine campaign when ho said, "There are no Alps!" and his other trenchant phrase, "Difficulties are just things to be overcome."

A foreign trade pioneer must be a fighter in spirit. The foreign field is no place for the indolent, the spender or the idler. He must train for conflict and not for an easy job.

It is this fighting opportunity which helps to make the 
field attractive to the American who is not accustomed to stop at hindrances when his ambition is fired. The Yankeo love of enterprise, eoupled with business daring, is usually suecessful.

Apart from these general essentials which we are too likely to take for granted and omit in our training plans, there are other more eonerete but none the less important elements in which we must train men for foreign commerce. These men must be in a position to know where they can get authoritative answers to sueh questions as the following :

What are the conditions in foreign markets for particular products?

Where can I get details of enstoms duties in foreign countries?

Who ean tell me relative to the regulations as to commercial travelers, taxes imposed upon them, ete.?

Where can I get such details for foreign countrics as advertising rates and the credit standing of prospective foreign customers?

What are the best books on packing, eonsular requisites, standard weight and measure, patent and trademark laws?

Where can I get up-to-date lists of foreign buyers for my goods?

Where can the information be found concerning shipping conditions, forwarding goods and finaneing my shipments?

How ean I learn about foreign contracts and the particular needs of the dealers who handle my products in other iands?

What about marine insurance?

Is there an anthoritative bureau for the translation of foreign correspondence?

What are some of the most worth while periodicals relative to foreign shipping and trade?

The man who is to become a specialist in his field must know something at least of all the above subjects, for specialists in foreign trade require something more than the definition which one man has given of a specialist-"a specialist is a crank on the thing in which you are not 
interested." He must have a general trade education to bo sure of the highest success.

Among the agencies which are devoting considerable time, attention and money to the answering of the above questions is the Bureau of Foreign and Domestic Commerce of the United States Department of Commerce in Washington, D. C. This burcau employs scores of men constantly to make digests of consular reports, together with the findings of the traveling trade advisers and commercial attachés of the United States, as well as gathering trade information from many other sourees. In connection with this bureau there are specialists connected with such matters as foreign tariffs, foreign customs rates, commercial treaties, trade-marks, patent laws, and almost every kind of service connected with exporting, importing and shipping. Their information has brought millions of dollars of trade to the American manufacturer and a letter to this burcau concerning any of the above questions will bring the latest information for the price of a pamphlet, and often free of charge. The Exporters' Index of this bureau contains lists of 17,000 firms in the United States known to be interested in exporting. The bureau has permanent offices in a number of the large eities in which lists of foreign dealers may be found, which lists are continually in the process of revision. We have found the members of the Bureau of Foreign and Domestic Commerco extremely courteous in promptly answering requests for information and the fact that the United States Government is behind the bureau and is expending a large amount of money for its extensive operations and services helps to make authoritative the information. This bureau also emphasizes the fact that the United States has come into the foreign trade field to stay. For a small sum the weekly Commerce Reports of this organization, which give a sweep of the world's trade, are sent to any one who is interested.

Other important information for training purposes may be secured from the reports of the National Foreign Trade Council. These may be sccured by writing to Mr. O. K. 
Davis, seeretary, India House, 1 Hanover Square, New York City. This council is composed of leading men engaged in foreign trade and shipping and its reports cover virtually every phase of world-wide commerce.

Books on business, such as those published by Appleton and MeGraw-Hill, trade papers such as Dun's Review, The Iron Age, The American Exporter, The World's Markets, and Export Trade will be found of help in such training, for these take up special branches of foreign enterprise and are editcd by specialists, and the contributors are men who have devoted years of their lives in practical and experimental touch with their specialtics in forcign lands.

The Pan-American Union issues literature upon all Latin American countries which has been of very great assistance in showing the political as well as the commereial condition of these republies and outlining the opportunities for commeree with the United States. This literature may be had by applying to the Pan-Americar Union, Washington, D. C. We also recommend the books published by Isaac Pitman \& Sons, 2 West 45th Strect, New York City, such as the Pitman Commercial Encyclopedia and Dictionary of Business (in four volumes); the Exporter's Encyclopedia, and the publication of the Gresham Publishing Company, London (British compilation), Modern Business Practice (in eight volumes).

There are also many sources of information available to the foreign trade student in the United States, such as the reports of the American Chamber of Commerce, the wide information gathered by the Philadelphia Commercial Museum and the more or less regular statements and bulletins of information issued by such organizations as the National City Bank, Guaranty Trust Company, and W. R. Grace \& Company. In nearly all of the large cities there are Chambers of Commerce or Boards of Trade whose secretaries are able to give information through their foreign trade departments or industrial bureaus. In some eases, as the Merchants' Association in New York, an active foreign trade information service publishes this material 
in weekly bulletins, and while local matters are included, foreign trade problems and opportunities are not neglected. There are also American Chambers of Commerce abroad from which important information may be gained. In Paris, Berlin, Constantinople, Naples, Barcelona, Rio de Janeiro, Buenos Aires and Shanghai, these American Chambers of Commerce have been of great service not only in producing a better trade understanding, but in assisting American manufacturers and business men with particular information. The Federal Board for Vocational Education, at Washington, has ontined courses of reading in foreign trade which it will send to any one interested.

It must be remembered also that our Ameriean Consuls, loeated now in virtually every great city in foreign lands, will be glad to answer questions and secure information when these questions state definitely what is desired.

It is probably true that the majority of successful Americans who have gone to South America and built up trade for their American houses have not been college men. Other things being equal, nevertheless, the man who has a baekground of collegiate knowledge and mental discipline is more likely to sneceed with the type of mind found in South America than the man who is "all business," with no ability to lighten his conversation with thoughts in the realm of what is known as "general knowlcdge." I think of a young man who devoted much of his thought in college to architectural study, who claims that this ono department of knowledge concerning which he knew something definite, has helped him more than any other one qualification in securing a foothold in one of the large South Ameriean cities. Entrances to business often come through avenues in which the arts play an important part. The South Amerieans love musie, literature and painting and among them there are most excellent architects, musieians, literary people and artists. They like to talk upon these subjects and the edueated man who interests them and is likable, gains a hold that naturally reflects profitably upon his business success. 
A qualification undeniably important for men, young or old, in going abroad is that which includes habits of life sufficiently well grounded to insure straightforward and upright living in a foreign land. While it is true that most business houses rightfully demand practical results from their employees, both at home and abroad, and do not inquire too strictly into a man's personal habits, it is important in choosing men for foreign positions to be reasonably sure that the men are not going to make shipwrecks of themselves and their company's interest by losing their heads, simply because they are far away from home and placed among people whose points of view, both moral and social, are often different from our own.

Furthermore, the American business man is often located in more or less lonely posts and for a time, at least, may bo deprived of the society and amusement to which he has been accustomed at home. Therefore, the man with a trained mind, who has some mental resources of his own, who can cndure spending an evening alone with a book or with a friend, and who is not dependent upon the stimulations of Broadway or the like, is much more likely to sueceed abroad than the one who depends upon external environment rather than upon his own inner resomees for satisfaction.

There is no doubt that by vocational study a man must greatly advance in the province of foreign trade. To this end, we quote a paragraph taken from a very important and suggestive pamphlet issued by the Department of Commerce under the title of "Training for Foreign Trade" which can be secured from that body by referring to Miscellaneous Series 97.

For argument, we may say that a young man enters an export office at 16 , is a salesman at 26 , and a manager at 36 . It is usually a 20-year pull to the position of manager. Yet it is possible to cut down the 20 years by substituting vocational study for some of the slowly acquired experience. For example, by studying until 19 or 20 the managerial rank may be reached at 30 -a gain of 6 years in a young man's life, in addition to 
greatly increased efficiency in the work done along the line of progression. The young man on the job may likewise reduce his terms of apprenticeship by supplementing actual working experience with systematic vocational study.

Finally, we would urge the increasing use of our schools (night schools, commereial and technieal sehools, and colleges). Our business houses, which in many cases have already begun to train their men in classes for work abroad, also our press and our trade periodicals all point to the need of getting thoroughly ready for American foreign commerce. Trained and capable men are required for forcign branch managers, for salesmen, for office workers, as well as for equipping our new merchant marine. No word is more strategic or vital in the realm of our overseas activity than the word "preparation."

\section{Practical Methods in Use in Eusiness Firms for Training} for Foreign Commerce.-In order to he able to present for suggestion and direction the conerete methods now employed by some of the largest American firms, and educational institutions to fit men for foreign trade positions, we sent the following questions to a carefully seleeted list of business houses and schools:

1. What agencies do you employ for training your employees for work in foreign countries? (Kindly describe any agencies or methods employed, such as courses of study, publications, welfare work abroad, libraries, reading courses, etc.)

2. What books or literature have you found most helpful for the purpose of giving your men general or specific knowledge coneerning your trade abroad?

3. Does your Company meet in whole or in part the expenses of employees who are studying outside to better prepare themsolves for foreign service in your firm?

4. Is there any particular class of men from which you recruit your force of employees?

5. What in your judgment is the comparative value of college men for foreign trade service in comparison to men not 
having a college training but who have had considerable experience in the firm's business?

6. What do you consider some of the most vital means for fitting men to take responsible trade positions abroad?

Among the answers received we quote the following, which we believe will be read with much interest and profit by all those now training their workers, or by those firms wishing to inaugurate systems of training to fit their employees for better service overseas:

\section{The Standard Oil Companr, New York City.}

Our policy is to confine our training to men especially qualified to take up this particular work. We, therefore, eliminate poor material before the elass starts and are thus able to concentrate the training on a few specially qualified men. These men in the past have been selected from the various universities and from our own organization. We are striving more and more to find among our own employees any who are particularly suited to take up this training.

Our classes are composed of about twelve men, six or eight of whom are given the foreign service training. In the past these classes have been started every ten weeks, covering a period of twenty-six weeks. We aim chiefly to teach the men the details of our business, the manufacture of our products and the organization and function of the different departments in our Company, in particular the foreign departments operating in the locality to which each man will be sent.

The course consists of ten weeks of practical expcrience in our refineries, where, under the supervision of an instructor, the men learn the manufacture of our products. They are then transferred to one of our marketing fields for ten weeks, where, also under an instructor, they learn how we market our product and how our sub-stations and general offices are managed. On the completion of this work they are transferred to the New York offices for six weeks, where in the various foreign departments they finish the training. During these twenty-six weeks they are trained by actual experience rather than by observation of the work.

In addition to this the men are given a course in the language used in the country to which they will be sent. Each week an 
officer of the Company or a Department Head gives a lecture on some phase of the Company's business, so that men may get a broader experience of the work they are to undertake.

A library of technical books is furnished to assist them in their refinery work. Also from time to time, depending on the particular work to which a man is assigned, other books are recommended.

During the period of training the men are paid twenty-three dollars a week, in addition to any expenses incurred in the performance of work assigned.

We do not restrict our work to college graduates, as we believe this is unnecessary, but we do stipulate that a man shall have had the equivalent in business experience. As a matter of fact we send a great many college men who apply to us for work out to one of our plants to get that practical experience which we deem to be of vital importance, not only because of what he may learn but also as a further test in judging a man.

\section{W. R. Grace \& Co., New York City.}

A matter of vital importance to such organizations as the Grace Company consists in the conduct of educational classes, intended both to bring students together in close personal contact and work to a common end and to fit them for particular fields of activity. In the home office of W. R. Grace \& Co., these classes meet on Tuesdays and Thursdays from five to six forty-five on the following subjects: Elementary Spanish, Intermediate Spanish, Advanced Spanish, Commercial Geography, Talks on Accounts, Typewriting Course (given in small groups of 3,4 and 5 persons).

In addition to these regular courses, special training is given for particular students and a series of lectures running through the year, upon subjects of most vital moment in the activities of the firm. Some of these lectures are given by heads of departments or specialists in the organization itself, while occasionally outside lecturers are secured.

A further assistance to the mental training of individuals is afforded by a carefully chosen library, a portion of which is filled with books for circulation and the other portion with reference books. Hundreds of members of the firm, at the home office, borrow these books every month for two weeks' reading, while the editorial department is constantly in demand by various 
members of the house who wish to consult maps, dictionaries, trade encyclopedias and various works in different languages, as these relate to their several departments.

The larger firms and corporations of to-day, in many cases, are composed of departments, each department forming almost a special business in itself. The tendency for specialization often works against coöperative unity. It is difficult sometimes for members in one department to have even a general knowledge of the varied activities of a large firm, thereby suffering a severo handicap relative to their own particular specialty. The monthly house-organ or corporation magazine furnishes a bond of union between employees often scattered throughout the country or the world. In these magazines, we find the personal element forms one of the most important features. The narration of personal events concerning the officers and employees of the firm, the publishing of pictures of persons in groups or individually, the just personal mention of long service or particular examples of efficiency, are all matters of great advantage in cementing tho work of the house and in developing the sense of personal responsibility and privilege on the part of the members. No matter how seemingly unimportant the work of an employee, it is always vital to his best output to emphasize, in his mind, the necessity of the highest grade of work on his part if the business is to succeed. It is this catering to the great value of the individual that has made many a firm succeed beyond its competitors.

The social club and, in foreign countries, the club or mess where employees live together, are means which have been found useful in developing and strengthening the personal elcment in the Grace Organization. The Grace Club at the home office consists of 500 members and during the year it is exceedingly active arranging dances, dinners and outings during the Spring, Summer and Autumn months, as well as organizing athletic teams for baseball, football, tennis and even a riding club. At these social gatherings, the directors of the firm are usually present and frequently in brief speeches give emphasis to the human side of business. The mixing together for personal acquaintance, however, is one of the chief benefits of such gatherings.

Among other indications of attention to the welfare of the employees, the company has a physician at the New York Office. With his assistants, including a trained nurse, he cares for the health of the 600 or more employees there. Any employee 
of the firm has the privilege of consulting the physician and securing medicine and treatment free of charge-a privilege which is greatly appreciated and which is intended also to increase greatly the sense of appreciation, on the part of the employees, relative to the attention of the house to their personal welfare.

Above and beyond all of these practical and far-reaching agencies, in recognition of the fact that the men and women of our business houses are the vital factors in production, a successful house will lose no opportunity to develop, among its employees, the house esprit de corps.

In my contact with this house in various parts of South America, I have been impressed with what is called the "Grace spirit." The attempt is made, successfully for the most part, to show the various agents and men connected with the company that the house represents a great American enterprise, and that each representative stands for something more than a mere business agent, in fact, that he reflects the ideals of the nation behind him.

I was much interested in the club or the "mess," as it is often called, where Grace men live together in South American countries. A house is rented and made homelike as a place for the men without families. A steward and treasurer are elected, and the house is equipped with reading matter, billiard tables, pianola and other conveniences for producing a homelike atmosphere. Many of the plants are situated far away from the cities and these clubs are virtually oases in far-away sections of Peru, Bolivia and Chile, where the comforts and amenities of civilization have not yet penetrated.

In the great nitrate community of Chile, for instance, there may be only a small circle of Americans representing the officers, possibly half a dozen or nine men who are responsible for running an enormous plant. Outside is the camp for workmen. The evenings for Americans in such localities are likely to be a nightmare of loneliness. There is lack of companionship and social opportunities such as those to which the men have been accustomed at home.

The company has been quick to appreciate this fact and to provide not only comfortable quarters, but to establish customs intended to give the officers a life by themselves, and to prevent such unfortunate mixtures with the camp community as would disrupt discipline and morals. I found it the custom for every one of the official staff from the manager down, after work 
was over, to don his dinner jacket preparatory for dinner, while afterwards, opportunities were offered for games and amusements in the club. As one man put it, 'None of us are inclined to find our way down to the camps in a dinner jacket. When you put on the dress of a gentleman you are quite likely to act like one."

On the big sugar estates at Cartavio, in Peru, a church has been founded, also a schoolhouse, a hospital and a moving picture theater. The influence of these organizations has been manifested directly upon the community of workmen. Formerly it was customary during the holidays for "every one to get drunk for a week," according to the statement of one of the men. One of the dealers in chicha, the Peruvian national drink, stated to a manager that, as a result of the church and theater he had been obliged to go out of business, for while he had been accustomed to sell ten barrels of chicha during certain holiday periods, it was now impossible for him to get rid of more than one barrel. It has further resulted that, instead of several days of shutdown on account of the dissipation of the holidays, there is rarely more than one day of stoppage on the estates through any inability of the men to work as a resalt of excessive indulgence in drink. The Grace Institute has helped in making these isolated plantations and estates enjoyable and livable. Last ycar, two hundred presents were sent down to this particular sugar estate at Christmas time, with several hundred boxes of candy and other gifts. Such work, as one man said, "has put Christmas on the map in this community."

American Locomotive Companx, Schenectady, N. $Y$.

The men selected for work in our Foreign Department are usually given a two year course of training in the Engineering and Manufacturing Departments, as well as some experience in the Foreign Office of the Company in New York City. The shop training is intended to familiarize the men with the Company's manufacturing methods and standards of workmanship, while the engineering experience covers the important elements in locomotive design and general calculation pertaining to the proportioning of locomotive parts. Literature is supplied dealing with the locomotive and the Company's practice, and in most cases the men have taken special evening classes relating to locomotive work.

After the preliminary training and service in the home office 
of the Foreign Department, these men are placed as assistants in the sales offices in foreign countries and are advanced according to the ability shown.

Such outside study as is required to prepare men for work in the Foreign Department is usually borne by the individual but not infrequently the expense has been partly carried by the Company.

Recruits are preferred from among college graduates, particularly those who have taken mechanical engineering courses. It has been the experience of our Company that college training has a decided advantage in developing a man's initiative and enabling him to analyze conditions relating to his work and find solutions for the problems presented to an extent not found in most men who have not had college training.

We believe the important elements in the training for foreign service are:

a. A thorough knowledge of the Company's mechanical practice.

b. A knowledge of the essentials of its engineering practice.

c. The handling of responsible work in the home office which would give an appreciation of the relation of work in the foreign field to that of the industry.

d. The development of sound judgment in business relations.

e. A knowledge of modern salesmanship.

f. A clear understanding of the characteristics of people to be met with in the foreign field.

\section{The Atlantic Refining Compant, Philadelphia, Pa.}

1. Q. What agencies do you employ for training employees for work in foreign countries?

A. Principally practical work, coupled with current discussions between Departmental Managers and myself, or my assistants, in addition to which a library is at the disposal of the members of the Export Department.

2. Q. What books have you found useful for studying trade abroad?

A. Practical Exporting, by B. Olney Hough, Exporter's Encyclopedia, and Trade Magazines.

3. Q. Does your Company meet in whole or in part the expenses of employees who are studying outside to better prepare themselves for foreign service in your firm? 
A. Not regularly, although it has been done at times. Sometimes covered by an adjustment in salary.

4. Q. It there any particular class of men from which you recruit your force of employees?

A. Always prefer stenographers with a High School education or better, although individual fitness on the basis of exhaustive tests, made before employment, is the determining factor. Always prefer men with export experience, and preferably a knowledge of languages.

5. Q. What in your judgment is the comparative value of college men for foreign trade service in comparison to men not having a college training but who have had considerable experience in the firm's business?

A. The college man's value lies principally in his better mental training to grasp and apply facts and generalize experiences, although in case of a choice between a poorly gifted college man and a talented man without college training, the latter would be taken in every case. Experience in the firm's business is always a valuable factor, but not as determining as the experience in foreign trade, at least in the case of service in the home office. In the case of foreign service, the experience in our line of business is one of the chief factors, but only secondary to personality, power of analysis, and general superior ability.

6. Q. What do you consider some of the most vital means for fitting men to take responsible trade positions abroad?

A. Provision of extensive training and study in offering tasks that involve responsibility, self-reliance and quick action, to test and develop initiative.

\section{American 'Trading Compant, New Fork City.}

1. Q. What institutions do you consider to be doing effective work in training students for our foreign trade?

A. W. R. Grace \& Co., National City Bank, American Trading Co., Arkell \& Douglass, Guaranty Trust Co., Harvard, New York University and other colleges that give a certain amount of theoretical training.

2. Q. What books have you found most useful to suggest to schools or business corporations for use in such training?

A. Practical Exporting by Hough, Foreign Exchange Explained by Escher, and certain Bank publications.

3. Q. Could you suggest certain places where schools or col- 
leges are coöperating with business houses in training men for overseas trade?

A. New York University, Columbia University, Harvard University.

4. Q. What do you consider to be the most vital subjects to be taken up in a course of study intended to fit men for foreign trade careers?

A. Routine necessary to exporting and importing, a certain amount of export finance, concentration and common sense, general executive ability, the power to handle adequately much detail work and to assume responsibility.

\section{International General Electric Company, Schenectady,} N. $Y$.

I am sorry to say that I cannot answer your questionnaire in a manner which will be very helpful to you, because we have not yet carried our work far enough. Indeed, we are just starting it. The following answer's will, however, inform you in a general way what we have in mind.

We are going to start a classroom course consisting of approximately 40 lectures with correlated reading, covering the organization and general methods of our company; an outline of the theory of business, banking, credit, instruments of credit and payment; foreign exchange; foreign customs and duties; an outline of the theory of accounting; a study of markets; national characteristics; and the methods of exploiting business, governmental regulations and commercial law in foreign countries. It is needless to say that our course will merely touch the 'high spots' of these subjects, but we hope it will stimulate interest and lead to further reading and study by the men who take the course. A library will be created so that suitable books and publications may be available. It is intended to have practically all of our men take this course, and the course will undoubtedly be modified from time to time as a result of our experience.

We have started classes in Spanish and French already, and these are fairly popular. Progress is not very rapid in the time which can be given, but I hope that in the course of another two years the advanced classes will develop into groups for the study of the countries in question together with their customs, methods of business, national temperaments, etc.

Some of our men have taken courses in advanced engineering or in business training from institutions that were available, 
and in a general way it is our policy to bear at least a portion of the expense of such courses if they are completed successfully. Generally the company is willing to assume 50 per cent of all the necessary fees.

Practically all of our men are graduates of technical schools and in addition have had experience in our testing department.

The technical nature of our business and the fact that our representatives are too far away to call upon factory experts for aid but must be able to discuss with eustomers all engineering details of the business, makes it almost essential that we employ men with technical training, only. There have been a few exceptions, but in these cases the men have picked up the necessary information during many years of work in our offices. These few men began as clerks and owe their advancement to their own exceptional characteristics. Probably they were high school graduates when they came to us. Without denying their merits, I think the general feeling is that four years spent in technical training would have made them even more valuable than they were or are; let us say at ages of from 30 onward.

A man to go abroad must first of all be acquainted with our methods, policies and our products in detail. My own feeling is that in addition he should have if possible actual experience in selling and in merchandising methods and he ought to have a good idea of banking methods, corporation finance, accounting, budgeting and statistical methods. It is of course, impossible to get all of this experience in the case of most men and it is to fill in the gaps that we hope that our course mentioned above will be of some value as well as in giving the men in the home office a more comprehensive interest in the work which they conduct.

\section{Department of the Interior, Washington, $D . C$.}

In answer to query No. 3 of your questionnaire, I would state that $I$ have found coöperation in the following cities: Boston, New York, Chicago, Seattle, Portland, Los Angeles, San Franeisco, St. Louis, Cincinnati, New Orleans, Pittsburgh and Cleveland.

In training for foreign trade it was the earlier practice, as you know, of our higher institutions to introduce a semester course of two or more hours on this subject of foreign commerce. In time as the subject became more clearly understood and the demand from business more pressing, the course in foreign trado 
developed into what might be called a major in this subject. This major would include markets and sales, banking and exchange, ocean transportation, maritime law, marine insurance, document technique, commercial correspondence, ete. There bas been little or no demand until the present that the several subjects offered be better coöröinated in respect to sequence with some emphasis upon previous training. If I can make any special contribution at this writing upon the subject of this inquiry, I would state that in my judgment the time has come when we need a far greater measure of specialized training in fitting men to engage or enter upon foreign trade courses. This specialization will naturally lead to a greater degree of group treatment of the subjects considered most essential and vital for foreign trade preparation.

\section{College of William and Mary, Williamsburg, Va.}

New York University, Boston University, Harvard University and University of Washington (Seattle), I consider to be doing effective work in training students for our foreign commerce.

Books I would recommend for foreign trade training are: Hough, Practical Exporting, Filsinger, Exporting to South America. Collateral: Koebel, South America, Cooper, Understanding South America, Collins, Straight Business in South America, Henius, A. B. C. of Foreign Trade, Wolfe, International Commerce.

National City Bank, Boston University (Havana Branch) in experimental stage, General Motors Export Co. are training men for overseas trade. United Fruit and Standard Oil prefer men with School of Commerce training.

Some vital subjects for a study course to fit men for foreign trade are: language and customs of the people; document work; marketing; principals of foreign trade, etc. I expect to follow fairly closely the scheme of courses of R. S. MacElwee, Director of the Bureau of Foreign and Domestic Commerce, Washington, D. C., which is outlined in his bulletin, Miscellaneous Series, 97. Our classes here take practice trips to industrial centers and to the ports to see the shipping, unloading, customs procedure, etc. This is the first year of our foreign trade work. It has developed far ahead of our expectations.

Georgetown University, Washington, $D, C$.

The school has enjoyed remarkable success in this course of Foreign Service. Starting with seventy students the opening 
semester (February, 1919), we had two hundred and ninety (October, 1919), and at present we have three hundred and eighty after having turned away over three hundred applicants for lack of accommodations. Although this year witnesses the first graduation, many of our students have already become well located in foreign service.

Due to the lack of suitable text books the School is having a number of our courses published in book form at the end of the academic year. Thus for next year we expect to have published a practical Chinese-English grammar by Dr. Chen, a Spanish course by a member of the International High Commission, a course on International Relations by Dr. James Brown Scott, Secretary of the Carnegie Endowment for International Peace, a course on Consular Procedure by Mr. Frost, Foreign Trade Adviser, State Department, a course on Sales Practice by Dr. MacElwee, Director of the Bureau of Foreign \& Domestic Commerce.

Students are examined by means of frequent written and oral quizzes and semi-annual examinations. We invite your attention to the last paragraph on page 10 of Bulletin 9 .

Bulletin 10, which gives complete announcement of classes for Second Semester of Academic Year, 1920-21, Georgetown University, can be secured by writing to The Regent, Georgetown University of Foreign Service, Sixth and $\mathrm{E}$ Streets, N. W., Washington, D. C.-Georgetown is presenting a two years' course in foreign trade at present and out of 400 students 300 are taking Spanish.

General Motors Export Company, New York City.

Unfortunately, on account of the recent and rapid growth of our export trade, very few Americans, trained and experienced in the export ficld, are available for foreign service. Therefore, the American manufacturer who wishes to expand his overseas forees and to develop his organization is obliged either to take men trained in the domestic field and to transplant them into unfamiliar surroundings and conditions abroad, or to give young men of the desired mental, moral and physical caliber a eourse of intensive training for over-seas service.

The General Motors Export Company has selected the latter alternative as the one most likely to provide men qualified to 
aphold successfully the best traditions of American business here and abroad. It has established and is now conducting the General Motors Export Company's Training School, which is designed to equip men to represent it in the various branches of its foreign activities after a thorough training in its classrooms, shops and offices.

Due to the fact that a year is the minimum time required to teach even men of exceptional ability the rudiments of the export business and the merchandising in over-seas territory of the numerous products (including motor cars, trucks, tractors, and lighting outfits) which this Company, as the export division of the General Motors Corporation, markets, it is necessary that the men accepted for training possess most of the known essentials for success in the overseas business fields before entering the Training Sehool.

Our Company maintains a library to which are constantly being added such books on business, commercial geography, and foreign trade in general as recommend themselves to our favorable consideration.

A daily News Annalist published within our office, and containing extracts on commerce in general taken from various newspapers and publications, domestic and foreign, is also used in giving our men general and specific knowledge concerning our trade abroad.

Since this Company offers to certain selected employees full enrollment in the School, and to any employee the privilege of enrolling for such of the Courses as will make him more valuable, it has not been felt necessary to recommend outside study.

Although it might be safe to say that the best men usually come from the colleges of commerce, and graduate schools of business administration, this Company has found good material within its own ranks as well as elsewhere. Since the course has been established only since April, 1920, sufficient time has not elapsed to make a definite statement which would serve as a guiding principle.

It is felt that, other things being equal, a college graduate will forge ahead faster after he has assimilated the technical knowledge necessary to the understanding of the business.

Naturally it is thought that the ideal means for fitting men to take responsible positions abroad is through the establishment of a training school operated by a Company; but since many firms would not find so expensive an operation profitable, it is 
believed that sufficiently specialized courses can be had in some of the larger universities.

This, of course, does not help firms which may be situated at a distance from these seats of learning. In such cases we believe that enrollment in recognized correspondence schools is helpful, but that it should be supplemented with weekly discussion periods, attended by executives of the Company and backed up with the employees' practical application to their own business.

\section{E. I. Dupont de Neyrours Export Companx, New York City.}

We have no particular school for training cur foreign representatives, but the Domestic Company maintains at Wilmington a school for the education of salesmen. This course takes from three to four months and educates the employees as regards the manufacture and use of the various products of our Company.

After this course has been completed a representative, if ho is to be connected with the Export Company, is brought to our main office in New York and kept there from one to two months and is given an education in our methods of doing business through our various departments, such as the Order Department, Advertising Division, Filing Department, etc., depending upon whether he is to be a salesman, a sales representative, or an office man in one of our foreign offices.

Before entering the services of our Company it is necessary for an applicant to intcrview at least three of our representatives and also to pass a physical examination. If the interviews and physical examination are satisfactory the applicant is then placed on the regular payroll and sent to the school for training, we continuing to pay his salary while he is in the period of preparation. Of course if he fails to pass the Educational Course his services are discontinued.

So far as the value of a college training is concerned I am not prepared to make any definite statement as very few of our representatives are college men and the few that are do not enjoy any better positions than those who have not had such advantages.

Practically all of the employees of the Export Company in executive positions are old employees of the Domestic Company, having grown up with the Company and been with it from ten to twenty years. Any new men that we have taken on have been chosen more because of their particular knowledge of the posi- 
tion in which we wished to place them than from any thought as to whether they had or had not a college edueation.

The Guaranty Trust Company, New York City.

We have no course of training designed particularly to train men for work in our foreign offices.

We have a Foreign Exchange and Foreign Banking Course in which about 280 employees are enrolled. Most of those taking the course are employed in our Foreign Department, although about one fourth of the total number eonsists of men and women from the other departments of the company.

The aim of this course is to give employees of the Foreign Department particularly and the employees of other departments, as well, a knowledge of the theory of foreign exchange and foreign banking and with it a practical explanation of the functions of our own foreign department.

While the course does not directly train men for foreign service, it indirectly should increase the fitness of the employees of the foreign department for work in our branches abroad. The practice of this eompany is to select for service in its foreign offices men who have had experience in our foreign department here. The greater proportion of employees in our foreign offices, however, consists of natives.

We have a library in the Educational Department for the general use of the students of all departments of the company. Part of this library consists of books on foreign exchange, foreign trade and acceptances. There are two other libraries in this institution: (1) The Guaranty Club Library, which contains a few books on foreign exchange and foreign trade; (2) the Reference Library, which carries a very extensive number of foreign exchange and foreign trade books, and also receives newspapers, magazines, and other periodicals on all phases of foreign exchange and foreign commerce.

All of these libraries are available to the use of employees at any time.

The employees of the foreign department eome from no particular class of men, except in so far as the general type of employees of banks, brokerage and business houses may be ealled a class. In some parts of the foreign department, especially in those dealing with foreign exchange, import and export training is more desirable. 
In recent years, however, the company has established an Educational Department which takes in about 40 to 50 college graduates each year, for the purpose of giving them a general training in all the departments of the company in order to fit them for positions of importance in whatever department they prove to be best fitted for after having completed a study of the company as a whole.

Of the college men who have come into the educational department and who have completed the general training' course, a number have already been sent to this company's offices in London, Paris, Brussels, Havre and Constantinople.

In my opinion, as a general thing, the college man with a sufficient amount of training in the home office is of more value than the non-college man of experience in service abroad, because of the college man's broader viewpoint on history, geography and political econorny of the various countries, because of his usually better knowledge of languages, and also because of his general superiority in matters of contact with foreigners, both in a business way and socially.

I should suggest as some of the most important matters of training for reponsible trade positions abroad, the following:

1. A thorough knowledge of the language of the foreign country in which the individual aims to work.

2. A broad study of the geography, history and commercial laws of that country.

3. A study of exporting and importing procedure both here and in the foreign country.

4. A study of foreign exchange and the financing of imports and exports by banks, both American and foreign.

5. An extensive reading of English, French and German methods of trade (selling and financing) in the foreign country.

6. A thorough reading of publications of the Bureau of Foreign and Domestic Commerce and other American periodicals on exporting and trade opportunities.

We have found the following books and literature useful in connection with our courses in Foreign Exchange, Foreign Trade, etc.: Foreign Exchange, by A. C. Whitaker; Foreign Exchange Explained, by F. Escher; Domestic and Foreign Exchange, by E. L. Stewart-Patterson; Modern Foreign Exchange, by V. 
Gonzales; Foreign Trade and Shipping, by J. A. de Haas; Foreign Credits, Special Agents Series No. 63, by Wolfe, Bureau of Foreign \& Domestic Commerce; Arbitrage, by H. Deutsch.

During the period of the war the work of the Edueational Department was carried on under diffieulties natural to such a period of change. Within the last few months new plans have been made for the organization of this work, and the earrying out of a more comprehensive and thoroughgoing program than has hitherto been attempted.

It has been realized for some time both by the Guaranty Trust Company and by other large financial and industrial concerns that for any business enterprise involving a personnel running into the hundreds or thousands, a well formulated educational program is one of the essentials of sound organization. The mere size of the enterprise makes necessary a considerable number of separate departments, the work of each department being highly specialized. Efficient organization entails also, through the various departments, a considerable amount of work involving somewhat monotonous routine. The cases are necessarily very numerous in which a man's work does not of itself provide the means for the proper development of his abilities. This may be true even of the responsible heads of the departments and divisions, who, while admittedly experts in their particular fields, may nevertheless be lacking not only in a comprehension of the work of other departments, but in the broad grasp of business and public affairs, which is so essential for the man who is to hold a high position in the banking world.

It is a conviction of this Company that every officer and every employee shonld be constantly growing, and that upon this growth in knowledge and power depends both the welfare of the individual and the whole success of the Company. There is a plain need, then, that a man's daily work should be supplemented by some carefully planned course of training, in order that the value of his services may increase with the continued development of his powers. While every man is primarily responsible for his own development, there is much which can be accomplished by the organization of a systematic plan of training. The Education Department is therefore studying the educational needs of our whole personnel and will provide for them as far as possible.

It is the desire of the Company to follow throughout its whole organization the plan of promotion from lower to higher posi- 
tions. In the selection of officers, for example, though the appointment of men from outside the Company has not been uncommon, it has generally been for the reason that the man selected has had certain necessary qualifications which were not to be found within our ranks. It is the definite policy, however, to develop and recruit future officers as far as possible from within. As a means to this end the Educational Department has arranged for the selection from various parts of our organization of a group of men who will be given a special course of training in the work of all the important departments of the Company and who will be given other facilities for broadening their knowledge of finance and business. This group is to be made up of men who have been with the Company for a period of years and who have shown by their loyalty to its interests, their whole-hearted devotion to their work, and the development of their powers which they have already achieved, that their value to the company is likely to increase with the continued development of their abilities. The Guaranty Trust Company, with its rapidly growing business and its affiliations with numerous subsidiary and related companies, is constantly in need of men with the necessary training, personality, and force of character for executive positions of responsibility and trust. It is confidently expected that the general training course which is being conducted by the Educational Department will provide a flow of men qualified for the exacting duties of positions of this kind.

The men who take this course of training will spend a certain amount of time in each of the fundamental departments, learning its work partially by taking part in it, partially by systematic study and discussion. There will be considerable differences in the knowledge which these men have of the various departments of the Company other than their own. The amount of time to be devoted to the special training will therefore vary. In some cases after a man has acquired a general knowledge of the work done by the Company in New York, he may be sent for a period to one or more of our foreign offices. The end in view throughout will be to broaden his knowledge and his point of view, so that in addition to the intimate acquaintance which he has with one or more specialized departments, he will develop that broad grasp of affairs so much needed by the executive charged with large responsibility. The Educational Department is progressing very carefully to the choice of these men, for the reason that a 
wise selection will be of considerable importance both to the individual and to the Company.

Arrangements will be made in the various departments for the work of the men who are taking this general training. In all cases it will be the aim to acquaint the man to some extent with the work of a department, or division, before he enters it. In the Bond Department the men will be given a special course of instruction in investments somewhat similar to that which has been given to bond-salesmen in the past.

In taking on new employees it has been the practice of the Company to assign a man to a particular department where he stays for an indefinite period learning thoroughly the work of that one department, but having little opportunity to aequire a grasp of what the other departments are doing. To a certain extent it is planned to modify this procedure by giving new men, who already have some knowledge of banking, an opportunity to learn the work of a number of the more fundamental departments before being placed definitely in a particular one.

In addition to the special course of training which bas been described, the Educational Department will also make provision, much as has been done in the past, for courses in certain subjects related to the work of the Company, such as Domestic Banking, Foreign Banking and Exchange, Credit and Investments, Business English and Languages. The department is also equipped to give advice and suggestions in regard to systematic courses of training offered by universities, commercial schools and other agencies.

As the war has brought into the service of the Company a much larger percentage of women than formerly, the Educational Department expects to make a somewhat special survey of their needs and make such provision for meeting them as may seem necessary.

Mr. Adriance, who is in charge of the educational work of the Guaranty Trust Company, was formerly professor of Economies and Banking at Princeton University. During the early part of the war he served as Director of the Bureau of Research of the War Trade Board. This was the official statistical organization of the Board. It had a personnel of over 200 and he was charged with the duty 
of making the statistical studies required by the Board in the conduct of his work. It is to be noted that business firms are seeking highly trained men to conduct their educational departments.

\section{Eastman Kodak Compant, Rochester, N. Y.}

The greater part of our foreign business is handled through Kodak Limited, in England, and not direct from the United States. Men sent from this country to those branches which are managed direct from here, fall into three general classes; manufacturing experts, managers and assistants for foreign sales branches, and foreign demonstraiors.

Production experts sent to our foreign manufacturing plants are invariably men with technical training, usually with a specialized knowledge of chemistry. All these men spend considerable time in our local plants before being assigned to posts abroad, the fundamental requirement being, of course, a thorough knowledge of photographic products and their uses. Their training is largely that given all local manufacturing experts.

In the case of managers and assistants for over-seas sales branches, and foreign demonstrators, a knowledge of our products and the manner of handling is of course necessary, but the technical knowledge of production is not expected. These men receive their training in the export division of our sales department. They become thoroughly familiar with methods of shipping and billing, with foreign correspondence, and the customs, requirements of the country to which they are to go. They are also expected to secure a reasonable familiarity with the language and with the general nature and conditions of the country concerned.

The company has at present a method whereby the tuition up to a certain point is paid for employees who satisfactorily complete courses in approved schools. At the present time this does not apply to those receiving private instruction.

There is not a special class from which most of our men are selected, save in the ease of technical experts, as noted above. Special consideration, however, is of course given to those already having qualifications which fit them for this work, such as a knowledge of foreign languages and customs, and a knowledge of photographic materials. It appears sometimes to be the ease that college trained men adapt themselves more easily to the con- 
ditions of foreign trade, and may more quickly secure a proper understandiug of foreign conditions and methods of business.

Some of the most necessary qualifications for work of this kind secm to be a knowledge of the product and the general policy of the company, and as thorough an understanding as possible of the language and mode of thought of the country in which business is to be earried on.

Boston University, Boston, Mass.

The courses in Foreign Trade training and in kindred subjects given at Boston University oecupy a prominent place in the curriculum. Special attention has been given to Latin-American relations and to the Spanish language.

In the past few years the "Laboratory plan" of combining class room instruction with practical experience in shop or counting-house has proved to be the most satisfactory for'm of industria] or commercial education. In the College of Business Administration of Boston University, for example, the four year course leading to the degree of Bachelor of Business Administration provides for one full year of supervised employment as an integral part of the course of study.

The University now announces a laboratory program for its Latin American trade courses, through the establishment of a branch college in Havana, Cuba, where students regularly registered in the college at Boston may take a part of their college course, thus having the opportunity to learn Spanish in a Spanish country, and to bccome personally acquainted with Spanisb American life and customers.

The Havana Branch is supported jointly by Boston Unirersity and a local Board of Guarantors, representing the principal business interests in Cuba. The instructors are members of the regular faculty of Boston University. The courses parallel those given in Boston University except that they are, in general, conducted in Spanish.

American students will not be admitted directly to the Havana Branch, but must spend at least one year in Boston, where they may take intensive courses in Spanish and in other subjects intended as special preparation for the work in Cuba.

Cuban and other Spanish speaking students may, after a similar preparatory year in Havana, transfer to Boston.

Without intending to reflect upon other institutions, I know 
of but one doing effective work of this nature: the College of Business Administration of Boston University.

Books that we have found helpful in connection with Foreign Trade training are: Kidd on Foreign Trade; Ford's Foreign Irade of the United States; Hough's Practical Exporting; Johnson and Huebner's Principles of Ocean Transportation; Escher's Principles of Foreign Exchange; Marshall's Industry and Trade; Savay's Principles of Foreign Trade; Selling in Foreign Markets, Bureau of Foreign and Domestic Commerce; De Haas' Foreign Trade and Shipping; Shugrue's Problems in Foreign Exchange.

An arrangement, similar to the Havana branch, by which students may spend two years or more of their colirse in China is now being completed.

\section{Armour and Company, Chicago, $7 l l$.}

The chief agency employed by us for training employees for work in foreign countries is work in the Foreign Department. Usually men are selected for this work who have had considerable and varied experience in our organization and have a general working knowledge of the business together with some idea of policy matters, as for instance in the case of the writer at present in charge of the Foreign Accounting Department, which includes Foreign Banking, Foreign Exchange, Marine Insurance and Shipping Documents.

After twelve years' experience in varions capacities in the domestic end of the business, he was sent to Europe where he spent the largest part of three years in the United Kingdom, France, Italy, Scandinavia and Germany to be returned to Chicago to the Foreign Accounting Department where after about a year's time he was placed in charge of the above. In other cases where the men were being trained for the Foreign Sales Department they were sent to South America and later to various European markets and afterwards brought into Chicago and attached to the Foreign Sales.

It might be interesting to note here a few remarks with regard to the policy adopted by some of the larger firms abroad and notably British and European firms. Young men and in some cases young women who show an aptitude for trade and are good linguists are encouraged to make themselves proficient in the language of the countries they intend to work in; are then taken into the offices, warehouses and plants of the house and given 
a general training of their whole business from the ground up, specializing in the work they intend to handle abroad. It is required that they study the history of the country they intend locating in, the political and social conditions as they exist and to become generally conversant with affairs in addition to the trade requirements, and when fully equipped they are sent out.

The most helpful information that we have been able to obtain for the purpose of keeping the Foreign Department informed regarding trade abroad is through the medium of weekly letters from our Agents and Managers at the foreign houses. These letters come in regularly and give a general view of the situation politically, economically and in faet from every angle. In all these various countries are published one or more trade journals and a careful study of these gives one a very good general knowledge concerning trade abroad. There are also several publications in this country that are of value to those who feel interested enough to make a study of these problems.

The Company does not meet any expenses for employees studying outside to better prepare themselves for foreign service. It is my understanding that in the European countries some of the firms do. We have, however, in many cases where we found men conneeted with foreign branch houses who were engaged locally and who show a thorough interest in and an aptitude for the work they have in hand, brought these men over to America and allowed them to spend considerable time going through the various plants and packing houses thus obtaining a practical education making them better posted to deal with their work. This has proven very beneficial.

In forming new organizations in foreign countries we have always found that with the proper nucleus for an organization based on trained employees from our service elsewhere, we have met with better suceess by employing a staff from people of the country where the business is being established. There are some exceptions but this is more the rule than the exception.

Our preference would be to use men in the more important positions in the foreign service who have had considerable experience in the firm's business rather than perhaps the better educated college men who lack experience, but the combination is most desirable.

There are several essentials necessary for fitting a man for the responsible trade positions abroad, one in particular being, that the average American abroad for a time at least is very 
narrow and provincial. Another is, that he is as a rule a poor linguist. Another very important requisite is, that a man in a foreign country representing an American house should adapt himself to the local conditions and thus avoid the so commonly prevalent custom (of Americans) of comparing local conditions with those at home and view things at times from the other fellow's perspective. He must become a public spirited man and show an interest in all things going on around him and should speak well the language of the country.

University of Pennsylvania, Philadelphia, Pa. (Wharton School of Finance and Commerce. Grover G. Huebner, Prof. of Transportation and Commerce.)

The Wharton School of Finance and Commerce offers a four year course of study to students registering for 'Preparation for Foreign Trade Service.' During the first year the four year students' courses are the same as those prescribed for all first year students in the Wharton School. They include business law; elementary accounting; general economics; resources and industries of the United States; government; and English. Specialization in foreign trade begins during the second year and increases in extent throughout the remainder of the four ycar period.

Mature students not expecting a degree, and unable to attend for a period of four years, may register as special students and complete the courses dealing directly with foreign trade.

The reading material for the class in foreign trade methods consists of especially prepared mimeographed assignments. Although a number of excellent books on foreign trade have been published, none has quite answered the purpose as a text book on foreign trade methods. Books that have been found useful include: Hough, Practical Exporting; Preciado, Exporting to the World; Business Training Corporation, Foreign Trade Course; Bureau of Foreign and Domestic Commerce, Selling in Foreign Markets, and also Paper Work in Export Trade; A. J. Wolfe, Theory and Practice of International Commerce. Many of the bulletins of the Bureau of Foreign and Domestic Commeree dealing with particular commodities and markets have been found useful.

Books used in courses dealing directly with foreign trade are: E. R. Johnson and G. G. Huebner, Principles of Ocean Transportation; and G. G. Huebner, Ocean Steamship Traffic Management. 
Text book on Marine Insurance: S. S. Huebner, Marine Insurance.

Text book on History of Commerce: E. R. Johnson and Collaborators, History of Domestic and Foreign Commerce of the United States.

Before graduation from the Wharton School eaeh student is required to complete a piece of research work, and business houses are coöperating to the extent of supplying them with available data, answering specific inquiries orally or in writing, granting extensive interviews and permitting students to familiarize themselves with their methods and organization.

Those subjeets which we feel have the most vital bearing on foreign trade are: Foreign trade methods; Exporting problems in selected foreign markets; Senior research; Ocean shipping; Commercial geography (courses dealing with the principal foreign markets) ; Consular service; Marine insurance; Money and credit; Foreign languages.

Harvard University (Graduate School of Business Administration ), Cambridge, Mass.

Our students are all college graduates to begin with. It is our aim, as far as it is practicable, to give the men as classroom work actual business problems that we have collected. This work in problems is supplemented, from time to time, by business men who meet the class, discuss a business problem with them, and leave with the elass a problem for solution. Later, these men meet with the members of the class and discuss their solutions of those problems. In addition to this problem work, our men are required during the four months of the summer vacation to engage in distinctly foreign trade work either in a business house or in research work.

Our course is two years in length. During that period we are more anxious to give men a broad but practical foundation than we are to give them the minute technical details of earrying on foreign trade transactions. Nevertheless, we intend to familiarize them more with the methods and to aequaint them to a considerable degree with the actual technical details.

United States Steel Corporation, New York City.

Our United States Steel Products Company have had in force for a year or more, a foreign service class for training ambitious and promising young men, who are in the employ of the Company, 
for foreign offices. There are always a number of men undertaking this course for various lengths of time as circumstances or immediate necessity permit, by which they progresis through the various sales, shipping and financial divisions of the New York office.

This training, in many instances, is supplemented by an especially routed trip through some of our mills where goods are manufactured.

In this course, we have included men employed because of their special qualifications in knowledge of foreign languages, or in technical or engineering training, for posts where this was imperative, and among them have been numerous college graduates; but such college training is not necessary and we have always given preference to our own men of good education, appearance and address, who have shown proper application and promise, as well as to those men already employed in our subsidiary companies who have had mill traiuing or experience in selling mill products.

Robt. H. Ingersoll \& Bro., New York City.

We have never been able to find either school or reference books that would be of assistance to our foreign representatives. We have, therefore, attempted to do the next best thing by getting men of the right sort, trained in the colleges and then putting them through a practical course of training in our offices and later in a foreign territory.

We employ language study, when necessary, in training employees for work in foreign countries and have company courses in selling or office management, etc., depending on the work the student is scheduled to do.

Most books of export theory and practice do not fit in with our plans and are apt to mislead the student. We, therefore, confine our future representatives' reading to our house literature.

We have no outside studies provided except language. Our men are paid while in training.

We recruit our force of employees largely from college graduates baving at least a rudimentary knowledge of language to be used in future work and with other necessary qualifications.

We find that the college man has infinitely more value for foreign service in comparison with men not having a college training but who have had experience in the firm's business. 
Assuming candidate has necessary natural qualifications, we believe the most vital means for fitting men to take responsible trade positions abroad are a careful grounding in the principles, policies and methods of our business, backed by some actnal experience here. If possible, we recommend some practical experience in a nearby 'export' territory under the supervision and watehed by a competent member of our organization.

\section{E. Waterman Company, New York City.}

Originally we sent from here, as far as possible, Americans who wanted to enter the foreign branch of our trade. Our universal difficulty was in keeping these men in the foreign country after they had arrived. One by one they have returned to good old New York or the U. S. A. Our policy now is to bring over young men from the countries in which they are to work and educate them here. We have been quite suceessful in this, particularly in Europe. In South Ameriea not so sueeessful, but having been rather slow in pushing the South American busines's for the last two years our poliey is somewhat unsettled. That is what we propose to do when we are able to enter this field afresh.

Westinghouse Electric \& Manufacturing Company, East Pittsburgh, $P a$.

The edueational and training program as condueted by the Westinghouse Electric and Mfg. Company is divided broadly into two parts:

1. Deals with the preparation of the individual for the work which he is hired to perform.

2. Is intended to prepare the individual for a position of increased responsibility in the organization.

During the past year approximately 3500 employees have received instruction through these programs. This number does not take into consideration those who have been benefited by miseellaneous lectures or who have received instruction for their work altogether on the job.

A number of technically trained men are selected each year who will ultimately take up positions in the Commercial, Engineering, Manufacturing and Ereeting Departments. These men are selected by personal interview and are given training in various phases of the Company's work as a preparation for their ultimate work in the organization. 
Individual schedules are made out for each man, in line with his interests, and the work available. In general these schedules comprise a period of production work in the factory where the student becomes acquainted with manufacturing processes, the various products which we manufacture, and with our manufacturing personnel. During this period of practical experience the young engineer spends two hours a week in conference with engineers and salesmen who handle the apparatus on which they are working in the factory. Within two months each student is expected more or less definitely to select the line of work in the organization which he will later on take up. From this time on, the course is intended to lay a broad foundation for this work by acquainting the student with the various kinds of work related to his future position in the organization. Some of the men spend a portion of their time in our branch plants or subsidiary companies; others receive practically all of their training at our main plant.

The training in general covers a period of approximately one year, the latter portion being given up to intensive training for the work to be undertaken, the student being given from one to three months' time to become aequainted with special information which he will need to know in handling his work.

After completing the training period students take up their regular work in the organization reporting directly to the executives in charge of the various divisions.

During this period of preparation these men receive a salary which is intended to adequately cover living costs.

A number of high school graduates are selected each year to take up work of a semi-technical nature in the organization. These men are selected by test and are given some practical experience in production and elerical work to acquaint them broadly with the company's system and organization. They then take up regular work in the organization with an opportunity to follow up further their technical training by means of evening schools.

Other courses of a similar nature are conducted for those who have had to drop out of college before completing their work and for special students who are sent in to be trained for work with our customers, either in this country or abroad.

Optional courses are conducted during the winter months at the Westinghouse Club in Wilkinsburg. These courses afford an opportunity for the students to study various lines of work 
which supplement the instruction which they receive at the factory in line with their desires.

Optional courses in Engineering are also available to any employee of the Westinghouse Company, through the Westinghouse Technical Night School which operates in the local Public School buildings. Through these courses it is possible for any individual who has the proper ambitions and qualifications to ultimately prepare himself for responsible work in the organization.

Approximately 1300 different students have been enrolled in this school during the present year.

In addition to the fonr year Enginecring Course, the school conducts a Preparatory Course for those who have not had eight grades of grammar school, a course in English for foreign born men for those who wish to learn our language and miscellaneous courses for women as a preparation for clerical, stenographic or other work carried on by women in modern office practice.

The school is supported by the students, the local Public School districts and the industry. Instruction is carried on by a staff of 75 men and women the most of whom are selected from the industry and instructed in the methods of teaching.

The majority of the graduates of this school are successfully engaged in commercial, engineering or executive work.

Four year courses are conducted for grammar school gradnates with a view of preparing them for trades work. The program consists of practical experience in the factory on various operations and processes, supplemented by four hours per week in the Trades Apprentice School. Those who complete this training are well qualified to follow the work of the trade taken, such as Pattern Making, Foundry Practice, Machine Shop Practice, Tool Making, and Design, or Electrical work.

These men are also available for executive positions requiring a broad understanding of manufacturing operations.

A two year course is conducted to prepare high school graduates for positions in our various drafting rooms. A preliminary period of intensive instruction is given the men to prepare them for tracing work. They are then placed in a position in the Drafting Room and given six hours per week instruction in the Educational Department.

After approximately a year in the Drafting Room these men are transferred to the factory where they receive practical experi- 
ence, becoming acquainted with processes, materials, etc., used in carrying out their designs.

In addition to these major programs a number of other courses are conducted to suit temporary or local needs. Among these might be mentioned noon lectures, for office employees, held in the Educational Department during the winter months; evening courses in Spanish; factory classes in English for foreign born men; stenographic training and part time training for Production, Time and Cost clerks.

The Westinghouse Company, as a memorial to those employees who entered the World War, offers each year four scholarships in technical schools, to employees or sons of employees.

A large number of our employees are enrolled in outside educational institutions such as, Carnegie Institute of Technology, University of Pittsburgh, Duquesne University, Y. M. C. A., Carnegie Library and Alexander Hamilton Institute.

The problem of training for foreign trade naturally divides itself into three parts:

1. Knowledge of the organization, products and policies of the concern represented.

2. Knowledge of the business conditions, people, language and customs existing in the foreign field.

3. A knowledge of exchange, shipping, inter-government relations, etc., necessary in order to conduct the business.

Our program has dealt primarily with the first of these three relations. The majority of our salesmen are technical graduates. Their industrial training has consisted of some practical experience on the various products which we manufacture, wcekly conferences with salesmen on the problems connected with each of our products, and a final one month's sales school which aims to coördinate the experience and to inspire the young engineer with the proper respect for the work and interest in it.

\section{The National City Bani, New York City.}

The work of The National City Bank in specifically training men for service in its foreign branelies began in 1915. Unusual advances had been made in establishing connections with the bank abroad, and still greater advances were planned. The need was distinctly felt for men of good education who had a general training in foreign banking and who would, under reasonable direction, give promise of development into capable foreign executives. It was decided to select a limited number of men 
from American colleges and universities, and with this in mind a few of the more representative educational institutions of the East were asked to coöperate in the selection of suitable candidates. The result of the plan was highly successful-so much so that it was continued each subsequent year, notwithstanding the interruption of the War. Details of the plan were changed, as experience showed a more practicable method, but in general the features of the training class have remained the same. From a small nucleus of twenty-three men in 1915, the elass has grown until at times there have been as many as seventy members. Last year the increasing interest of American men in foreign commerce, coupled with the knowledge that a training course for foreign service was offered by this institution, resulted in more than one hundred schools and colleges making nominations of over three hundred college students for entrance into the class, in addition to a large number of applications which were received at random.

The college students are brought to the Bank for the two months' summer vacation, during which time they are rotated, according to a definite schedule, through a number of the more representative departments of the Bank. They return to college in September and come back to the Bank the following summer. Upon graduation from college, they enter the Bank as permanent employees and are then placed in the department for which they have shown the greatest aptitude, and where their services are most needed. Thus, a man wholly inexperienced in banking is given first a general background, and then an opportunity to specialize in the line for which he is best fitted-credits, collections, auditing, etc.

Supplementing the practical work in the departments is a schedule of text book work and lectures under the direction of our Educational Department. Modern languages, eommercial geography, elementary banking, foreign exchange, credits, and similar subjects are touched upon. In this connection we have used the following books:

Foreign Exchange Explained, by Franklin Escher; Foreign Exchange, by A. C. Whitaker; The Meaning of Money, by Hartley Withers; Practical Exporting, by B. Olney Hough; Elementary Course in Banking Practice, of the Benjamin Franklin Institute; The Practical Work of a Bank, by W. E. Kniffin.

During the period of training the men are paid a salary which will enable them to live respectably in the city, and upon assign- 
ment to foreign service are given an advance for elothing allowance to help them prepare for life abroad. A club house, maintained in conjunction with the activities of The City Bank Club, offers accommodations for members of the training class at a reasonable figure, in a convenient location, and in a congenial atmosphere. In addition, the members of the class are urged to take such outside educational work as will complement their preparation in the Bank. The expense of such courses, if approved before registration by our Educational Department, is refunded to the student to the extent of fifty per cent.

The original intention of the training plan was to use only men of college education, and, with few exceptions, this plan has been followed carefully. With the coöperation of the college authorities, the names of two or three representative men from each institution are presented to us and from these nominations are selected the men whom we can accept for training. Theoretically, of course, the college men should have the advantage over the man who has not had a college training. It is on this assumption that our organization of the College Training Class is based. This does not mean in any sense that only college men succeed in the foreign field. On the other hand, a large number of representative men from within the organization of the Bank, who have not had college training, have been sent into our branches and have given most satisfactory accounts of themselves. Usually, however, they are men who have been with the Bank for some little time and have had the advantage of experience which the college man has not had. Having set the standard for a member of the class as graduation from an American college, we have observed this condition more as a matter of uniformity than because we have found greater suecess and satisfaction from this class of students. In preparing men to take places of responsibility abroad, we have found that the only practicable way is to put a man on the same kind of a job in the Home Office that he is expected to fill or supervise abroad, and to increase his capacity by letting him solve here, under capable supervision, the same kind of problems that he will be cailed on to solve later. A well trained mind, good address, and a forceful and pleasing personality are essential to his success. These attributes, however, are more the result of a man's own application and endeavor for improvement than the means which are placed within his reach by way of better fitting him for responsibility. 


\section{Packard Motor Car Company, Detroit, Mich.}

Wo have found it difficult to secure suitable traveling representatives for foreign work. Considerable experience in our industry, and particularly a wide familiarity with our own products and methods are essential. And we have not found that anything can take the place of this experience, not even a college training, as much as we value that.

I am of the opinion that actual experience abroad, following thorough American training in business practice, with such additional technical or special knowledge as may be requisite, will be found the most satisfactory means "for fitting men to take responsible trade positions abroad."

\section{The Texas Company, New York City.}

In the matter of training our employees for work in foreign countries we have worked out our own course, consisting of theoretical instruction and practical application. We have found that books help some, but we rely chiefly on training the men after they arrive in a foreign country in the spirit of that country and in our methods.

Due to his larger training we prefer the college man, if he is the right man.

A man must have a clearly defined conception of his future career governed by common sense. He should have a willingness to begin with small things and minding his own business until progressively his opportunity has come. He cannot be 'fitted' over night. Determination will always tell the tale.

The firm must choose the right man, or unhesitatingly eliminate the wrong one. It is important for the firm to make the employee feel that he is wanted, to give him a training through books and practice, and, if he deserves it, to let him feel that he is trusted.

\section{Burroughs Adding Maohine Company, Detroit, Mich.}

Our organization is divided into two units, viz.: sales and service. We have, in addition to our various subsidiary companies abroad, a great number of sales agents and dealers situated in all parts of the world. Our subsidiary companies are usually managed by men who have seen years of active service in the domestic organization and who are in our judgment peculiarly fitted to apply to the countries which their operations cover the methods in use here in the United States.

Quite often we have calls from our different dealers to supply 
them with trained Burroughs salesmen as well as mechanical men. For some time we endeavored to operate a sales school here at the home office to which our different dealers could send their salesmen for more advanced instruction. This has been tried for a number of years and it was finally found that results were not commensurate with the cost and this policy has therefore been discontinued.

It is very difficult indeed to endeavor to train a salesman for work in the field unless he has already been in the marketing end of our business and knows salesmanship as well as the different policies of the Burroughs Company. The only exceptions we make to this rule of accepting men for sales training at the present time is in giving them more advanced information regarding our newer models of machines.

On account of the service which we endeavor to render our customers in all parts of the world, we maintain a mechanical school here at the factory which is open to members of our different foreign organizations which are already actively engaged in Burroughs work. In the event a foreign agent cares to send one or more men to the factory for mechanical training, he pays their transportation to Detroit and return, and during the course of training which takes from three to six months, we pay these students a living expense of $\$ 25.00$ a week.

There is no particular elass of men from which we recruit our people who are to be sent to different agencies abroad for sales work. We have a set policy that we will send abroad only men ehosen from our domestic organization who have made good records and have had a number of years experience in the marketing of Burroughs machines here in the United States. Our organization is so large (at the present time consisting of approximately 2000 salesmen) that there is hardly a nationality which is not represented within its ranks. It is our conclusion that these men prove a great deal more successful than those, regardless of whether they have had college training, who are not in possession of experience in selling Burroughs machines here in the States.

As far as our particular business is concerned, we will say that we consider the most likely timber for field or sales work abroad to be men who have proven successful in this country. Human nature is the same the world over. People in China or South Africa can be sold Burroughs machines if the proper psychologieal contact can be secured. Even the typical American sales- 
man, filled with "pep and ego," can prove successful in other countries if he qualifies for his work, studies the people, and in fact if 'when in Rome he does as the Romans do.' It has been my good fortune to spend three years in the Far East for this Company. My experience previous to going to China, Japan and the Philippines, was gleaned from years of work and study in the domestic organization. I found that to sell the Chinese, different sales talks were of course necessary, but by close application and study of their needs, peculiarities, and in fact, their entire life, it was simply a matter of human nature after all, and that in order to be successful in selling in those countries one had only to obtain the proper contact.

\section{UNIVERstTy of VIRGinia, University, Va.}

Our experience in training men for foreign trade has been confined to preparing them for service in Latin America. Our resources here have not been great enough to permit us to take in other fields.

The principle upon which we have based our work is, that men who are to go to Latin American countries should, first of all, possess such temperament, or personality as will enable them to get along' with the Latin-Americans. In my judgment, a man's ultimate success will depend more upon this factor than anything else in this field.

A thorough speaking knowledge of Spanish or Portuguese is essential, with French, if possible. Most of the men I havo been able to send out have spoken both languages-that is, Spanish and French or Portuguese and French.

Such men should have a thorough knowledge of geography, social conditions, and general history of the region. In addition to these, I try to induce them to study the literature and current political conditions as well.

These men should have a thorough training in Latin American business methods, trade routes, transportation, packing, and the like.

When the four essentials enumerated are based upon a good general education, in which the theory of economics, and courses on money and banking, foreign exchange, and the like, are included, the men who complete the work as suggested are ready to start.

It has always been my aim to give my students such knowledge of the conditions, the peculiarities of business as it is conducted 
in Latin America, that they will be able rapidly to work up to executive positions and take their places among the commercial diplomats that we need so badly.

In giving this training, I have so arranged my courses in Spanish as to give my students a very considerable amount of information about Latin America while teaching them to speak the language. And I also give a general course on Latin America, which includes detailed geography, history, social conditions, political conditions, and trade relations, both internal and external.

It will doubtless be of interest to you to know that your own book, Understanding South America, is one of my stand-bys, and is constantly used as a reference work in my course on Latin America. Enoch's Republics of South and Central America, Sweet's History of Latin America, Aughinbaugh's Selling Latin America, Pepper's American Foreign Trade, and the various standard works on separate countries are also used.

During the past few years, I have consistently adhered to the practice of discouraging all students who apply to me for training for the Latin American field, unless I am convinced that they have the temperament and personality that will enable them to live in harmony with the Latin Americans. The result is that about two out of every ten students thus applying 'pass' my inspection and tests. I believe that this is the only fair way to approach the problem, and $I$ believe that my method is justified by the results. Every man I have recommended so far has made good.

As I suggested, our resources here do not yet allow us to do all we should like to do. Like most state institutions, we lack funds, and cannot give all the courses that should be given. We hope, however, in the near future, to be able to expand our courses, especially in geography, foreign trade methods, and international exchange. We shall, in all probability, continue to put most stres's on preparing men for the Latin American field -which is, of course, one of the most vital as well as most difficult of all.

Stracuse Universtty, Syracuse, New York.

Some of the larger colleges are doing effective work in training students for foreign commerce by offering courses dealing not only with the broader aspects of foreign trade and commercial policy, but with the essentials of practical exporting 
from the point of view of the American manufacturer desirous of extending his foreign markets. A few Y. M. C. A. classes in foreign trade are also doing excellent work.

Books we have found helpful in foreign trade training are: Hough, Practical Exporting; Savay, Principles of Foreign Trade; Ford, The Foreign Trade of the United States; Selling in Foreign Markets, Bulletin No. 81 Miscellaneons Series, Bureau of Foreign and Domestic Commerce.

Particular schools, where the instruction in training men for overseas trade is coöperating with business houses engaged in foreign commerce, are Boston University, New York University, Columbia University, and Tulane University at New Orleans. Such coöperation is also being furthered at the University of Chicago and in the College of Business Administration at Syracuse University.

We believe some of the most vital subjects in training for foreign trade are: Commercial and Industrial Geography, Marketing (including Advertising and Salesmanship), the principles of business organization and administration, the commercial policies of the varions nations-special attention to tariffs, commercial treaties, and shipping policies, and Political Science, dealing especially with the diplomatic and consular service.

In our foreign trade at Syracuse University, we are emphasizing four rather distinet, and yet necessarily correlated features:

1. A course in governmental, commercial policies with special reference to relation of those policies to actual importing and exporting: the tariffs, treaties, systems of public trade promotion, etc--in short, the entire environment that the government builds up around the trade of its people. This is followed by a consideration of practical exporting and importing dealing in detail with the four grand divisions of such trade:

a. The study of foreign markets, the purchasing power, demands, and trading customs of the people, the strength, resources and methods of foreign competitors in those markets.

b. The suitable means of reaching various markets; through direct selling, commission houses, combination agents, etc.

c. The means of trade development; the use of advertising, correspondence and traveling salesmen.

d. The technical elements involved in handling export orders: financing, insurance, and other documentary work. 
2. Following the rather broad course just outlined, the student specializes as thoroughly as time will permit on a particular phase of foreign trade, dealing with the marketing of a special product in a limited trade area.

3. An attempt is made to secure the best available information on such subjects mentioned above from local business selling abroad.

4. A final step is to be the encouragement of students to undertake work during the summer with the export departments of various businesses as a proper supplement to such training as we are attempting here.

The National Cash Register Companx, Dayton, Ohio.

We have our own Branch Offices or Agencies in most foreign countries. Our men, therefore, are trained locally in most instances. In recent years we have had very few men coming to the factory for training. Instead, we have Field Instructors, who are in constant touch with the factory, visiting the Agencies and helping local agents to train their men. Very often, when a new man employed by one of our agents, shows that he has the qualifications of a good salesmen, he is sent to one of our branch offices for the purpose of spending some time in the field with our experienced men. In this way his natural selling ability is developed in actual practice, and he receives the benefit of the experience of the older man.

We hold frequent schools for salesmen. This is done not only in our domestic field, but also in our foreign field. For this purpose we have prepared a manual for salesmen, which is revised from time to time. This has the principles which have proved to be successful in our business. We also have outlined in a pamphlet the fundamentals to be followed in employing and training salesmen. As a complement to this we have a pamphlet outlining a course of study for new salesmen, and another one outlining programs for conventions of older salesmen.

We use no special book or books as reference. Our manual is made up of ideas gathered from all sources, but principally from the experience of our most successful salesmen. We naturally recommend that our men read good selling literature and keep abreast of the times.

The matter of remuneration during the period of training depends on the nature of the man's position. For instance, if we take a man from our office force and put him through a 
course of salesmanship study, his salary as an office man continues during the period. On the other hand, if the man to receive training comes from the outside, we test his interest in our proposition by making him sacrifice something. Usually he is paid no salary, other than to cover his living expenses while attending the course. In this way the student feels that he is losing what he might have otherwise saved in his former position. This fact makes him feel his responsibility in his new undertaking.

The above is also true of the men who are from time to time sent from the foreign field to our factory to take a regular repair course. Such men are paid a salary sufficient to keep them comfortably located.

When a man is going from the factory to the foreign field, either as a salesman or as manager or assistant manager, he is given the opportunity to visit two or three of the principal cities in the United States where we have Company offices. This is done for the purpose of giving the man the benefit of the education which comes from traveling, and also to give him the opportunity of personally seeing how our most successful offices are actually conducted. His salary and traveling expenses while on these educational trips are paid by the Company.

Besides the salesmen and employees who come to our factory or to foreign branch offices for training, we frequently have agents or their salesmen and employees who come to our factory or branch offices merely for a visit. These visits may be for one or two weeks, or merely for two or three days. In such instances, of course, they do not receive any special training, and naturally do not remain with us long enough to be placed on the Company's pay roll. They, therefore, receive no remuneration, but the Company always pays their hotel expenses while in Dayton, or at the eity where the Company office may be located.

We do not recruit our salesmen from any particular class of men. Specialty salesmen, however, are usually the men who have the qualifications necessary for our business. Men who have been in business for themselves, and especially clerks in retail stores, also offer good material for our business. Another good field for recruiting salesmen is found by us in the men who have been in our factory or offices for some time, as they know our business and are well acquainted with the Company's ideas and policies.

The man with a college education and the man with a high school education have the same chances for success in our busi- 
ness. A thorough knowledge of the business, gained in practice, and knowledge of the language of the country where the man is to be located, is the best education he can have. There is no reason why a man without a college education cannot be well read, polished and up-to-date. Without these qualifications he is not fit for foreign work. It is not so much a man's theoretical or school education, as his actual experience and knowledge of business, that counts.

In fitting men to take responsible positions in the foreign field, we have always borne in mind the following points:

1. Knowledge of the language.

2. Actual work in the Foreign Department of our factory. to familiarize the man with foreign business methods, correspondence, literature, newspapers and the like.

3. Study of the article from a mechanical standpoint at factory. Whether this study is to be elementary or thorough, depends on the nature of the position. A salesman does not require as much mechanical knowledge as a repairman.

4. Actual practice in the foreign field in company of local experienced and successful salesmen of our branches. This is to familiarize the new man with local business methods, prices, and terms. All men receive a course in selling instruction before they leave the factory. 


\section{CHAPTER VI}

\section{LITERATURE AND STUDY COURSES FOR FOREIGN TRADE REPRESENTATIVES}

If a man empties his purse into his head, no man can take it away from him.-Franklin.

The awakening of the United States to a real participation in foreign commerce has brought forward a flood of literature during the past few years. Government departments have issued bulletins and pamphlets in large numbers, special institutions have been organized to assist foreign traders and have put forth all kinds of pamphlet and periodical literature, business houses and banks with house organs and other literature have added to the volume, while a large variety of schools and private institutions have devoted much time and print to the subject. As a consequence the foreign trader finds himsclf more or less swamped in a great sea of material. It is the purpose of this chapter to make a few suggestions relative to literature and courses bearing on world trade.

The preparation of such literature has been attended by the difficulties inherent in the inauguration of any movement of such wide proportions. Foreign trade routes and national boundaries have been changed so rapidly of late it has been difficult for text books to keep up with the changing face of the world. Each department of trade, furthermore, has been enlarging and becoming more and more intricate with every passing month until a considerable amount of literature is necessary to cover any one special field like shipping, banking or export and import. 
Our sehools have labored under the difficulty of securing properly qualified teachers. The teachers in many eases have not had contact with practical and experimental trade problems and procedure and the business man who has been called in to lecture, while he has known his specialty, has lacked knowledge of how to present his subject, limiting often the results. It would seem as though the successful teacher of such subjects in the future would be a man who has had some years of experience in the actual work of overseas commerce, from which activity he has gone into our commercial schools and other institutions of learning to devote himself to teaching.

This would be in line with the instruction which is given in many institutions in such subjects as engineering and commercial and scientific studies. As one trade expert has expressed it, "The teacher of the future should be a graduate of the school of foreign commerce, who, after some time in service of foreign business, returns to teaching."

The subject matter of foreign trade involves several classes or divisions of study. Among these may be con. sidered the technique and routine of exporting, in which the trader as a specialist must be familiar as any workman should be with his practical tools. Another division would be the great commercial areas of the world and the study of the markets which these furnish, while in a third group are language studies, which are absolutely essential for the foreign trade representative.

It goes without saying that the well equipped foreign representative must master some good and authoritative literature relative to sales practice, technical documents, foreign correspondence, packing, foreign advertising, exporting, ocean transportation, consular procedure, tariffs and commercial treaties. He will specialize upon certain of these in accordanee with the nature of his work, but will also do well to specialize upon that part of the world in which his work is to be localized.

We know of a certain man who was told by one of the 
officers of his company that he was to be sent in six months to Chile. This was a challenge to the man to begin immediate study and preparation and the result has been that this man has become one of the best authorities on business, eommeree and international relations with Chile. Among other preparations he attended an evening sehool in the firm with which he was assoeiated, taking up the study of Spanish and two or three other courses in commereial procedure. He talked with men who had spent years in the country and also achieved aequaintanee with a good number of Chileans living in and about New York. He sent letters to men actually on the ground, asking pertinent questions relative to the specialty of which he was to have charge. He gathered a small but valuable library of books and literature covering the history, polities and eommercial evolution of this vigorous southern republic. The Bureau of Foreign and Domestie Commerce, Federal Trade Board for Vocational Edueation, the Pan-American Union, the United States Shipping Board and the National City Bank of New York were found to be sourees from which helpful material eould be seeured. A meeting of the Foreign Trade Couneil and eonventions of Manufacturers Associations gave him the privilege of getting into toueh with many men who afforded mueh light upon his training. This man stated to me that he never worked so hard or with such great interest as during these six months of preparation. He also stated that the time was insufficient, but that it was long enough to give him an idea of his field, to lay the foundation of his own personal study and to determine to make himself a specialist upon Chilean matters.

The emphasis, moreover, upon language study both for eourses and personal preparation can hardly be over-estimated along with this subject of technique and commereial geography. If any one realizes that there are ten or twelve commercial languages and that each one of these languages possesses possibly 50 trade vocabularies, it 
becomes necessary for the person to get his particular trade completely in view before beginning his language study. Of course the earlier a man begins to acquire a foreign language the easier it is for him and the more rapidly will he acquire it.

The chief commercial languages for the American to learn to-day are, Spanish, French and Portuguese. If the time is short for preparation it is recommended that the student confine himself quite largely to the commercial or utilitarian side of his language training. Language for the foreign trader is an advantage for business, and is primarily for vocational use, but no man will study seriously any foreign language without securing a culture together with a knowledge of literature and history which will be of inestimable value to him. As soon as he begins to turn the corner of facility in speaking the language and recognizing the familiar sounds there will dawn upon him something of the delight which comes from learning a nation's spirit, moods and temperamental reactions, and if he is wise he will devote many a spare hour to devouring books in the native language which will aid in giving him the atmosphere of the country and the temper of the people with whom he is to work.

Among the places found convenient for teaching subjects of foreign trade are night schools, extension departments of our colleges, high schools and through the regular studies of commercial and technical institutions.

It must be kept in mind that there are two classes of men to be trained, men who are to stay at home as well as those who are to go upon overseas duty. Wherever the student begins and continues his study, care must be taken that he be trained particularly for the work and the country in which he is to be engaged, since methods and customs vary so greatly that one man can hardly master the details of forcign trade in every port of the world.

The results which have already been obtained by a few business and banking institutions, notably the National City Bank of New York, in training courses for prospective 
foreign bankers and traders suggest the valuable opportunities offered by large firms to train their employees while in the midst of their actual contact with the field.

The head of a business firm may well insist that certain of their employees have the facilities necessary to fit them for special positions and the designation of such employees will add dignity and a sense of obligation to the employee. Such studies should be considered as a part of the work of the firm and the attendance upon the meetings and the quality of the work done should figure in the reports to the business house from time to time.

In some cases the firm has refunded tuition fees to the students who have devoted themselves successfully in outside classes in preparing for their special lines of business.

As an example of some of the courses which are being presented in onc large foreign trade firm are the following groups of study:

$\begin{array}{ll}\text { Elementary and advanced } & \text { Talks on Accounting } \\ \text { Spanish } & \text { Talks to Junior Clerks } \\ \text { Commercial Geography } & \text { Spced Stenography }\end{array}$

The selecting of teachers for such courses is an important one. The instructors are often taken from high schools of eommerce or technical institutions located near the business house. Lectures are given, usually by members of the firm on different topics.

The following course of lectures is scheduled for one New York business house dealing in foreign affairs:

Export Accounts

Produce Accounts

Control Position

Auditing

Agencies Accounts
Foreign Accounts

Branch House Accounts

Cashier's Books, etc.

Outward Shipments

Résumé and Concluding Talk

We shourd like to commend the plan of a definite arrangement entered into by a business house with students to work out of business hours or during the summer vacation, training themselves for their vocations. The National City 
Bank has been very successful in taking college students and preparing them for useful careers, both for banking in the United States and in the branch offices of this institution abroad. More and more students are coming to business houses to begin work in which they may fit themselves for posts abroad.

This vacation work in a business house is invaluable to the student who intends to engage in foreign commerce and points him to the kind of training which should occupy his constant thought while still at school.

As to the length of time for courses of study which are intended to fit a man properly for overseas trade, it dcpends entirely upon the man and the amount of work he can do outside. Six months or a year, however, of more or less steady application are required to give a breadth of knowledge sufficient for a background for foreign trade training. Much of the particular training will be given to the student in the actual business when he is sent abroad to a branch house by the home firm.

Courses for Salesmen.-There is no subject of more vital importance to the manufacturer or exporter than that of finding a market for his goods abroad. The sales course naturally includes not only the actual technique involved, but as well, a clear understanding of the various trade channels used in overseas trade.

The student in this course should be acquainted with the various selling methods used by different classes of American exporters. The instructor in this course should be able to furnish readings as well as give opportunities for discussion of these problems and we are suggesting the main headings for an outline of this course, prepared by. the Department of Commerce at Washington:

1. Survey of sales problems.

2. Study of the market.

3. Direct saies problems.

4. The export middleman.

5. Agents and agencies.

6. Traveling salesmen. 
7. Correspondence, catalogues and advertising.

8. Export combinations.

9. A contrast of markets for American hardware.

10. Factors affecting marketing of electrical goods.

11. Miscellaneous sales factors.

12. Terms of payment.

13. Terms of delivery.

14. Tendeneies in economic reconstruction.

15. Export trade aids.

Dr. Guy Edward Snider has prepared under the direction of the Bureau of Foreign and Domestic Commerce and the Federal Board for Vocational Education, certain material for use in a course as suggested above and his book on Selling in Foreign Markets, Miscellaneous Series No. 81, may be purchased from the Superintendent of Documents, Government Printing Office, Washington, D. C., for 50 cents.

The following book references relative to sales practice will be found of use to those who wish to specialize in this vital department:

Exporting to Latin America, by Filsinger. (D. Appleton \& Company).

Latin American Yearbook for Investors and Merchants.

Principles of Foreign Trade, by Savay. Ronald Press.

Encyclopedia of Latin America, Wilcox \& Rines.

Direct Exporting, by Wyman (Business Training Corporation set).

Practical Exporting, by Hough.

Foreign Trade Books, edited by Dr. E. E. Pratt (Business Training Corporation).

American Methods in Foreign Trade, by Vedder.

Foreign Advertising Courses.-We have presented in another chapter certain general suggestions and conditions relative to foreign trade advertising, but the following outline furnished by the Bureau of Foreign and Domestic Commerce will be found useful by those who desire to study advertising principles and policies in groups: 


\section{Surver of the Field:}

A close study of the field to be covered by the advertising campaign must be made from the viewpoint of the advertiser. The knowledge of the general conditions of the field in question is necessary as a background. In addition to this general knowledge, such matters as the following must be considered from the advertising viewpoint:

Racial characteristies. (2) Pride and prejudices. General national psychology. (4) Seasons. (5) Climate. (6) Currency. (7) Metric system. (8) Distances between consumer and seller, etc.

Three points in particular are outstanding: (1) Purchasing power. (2) Literacy. (3) Percentage of urban and rural populations.

2. Local Advertising Practice:

The state of advertising in the country under consideration and in the locality to be reached:

Consumer advertising.

Dealer advertising, and assisting the dealer.

3. Newspaper Media:

Great dailies:

Morning papers.

Evening papers.

Sunday editions.

Secondary papers.

Small sheets (local papers).

Weeklies.

Monthly magazines.

Their appearance, character, influence, circulation, clientele, size, quality of paper, general appearance, and other characteristies.

Individual experience of advertisers.

4. COPY :

Copy in regard to localisms.

Dangers of the "direct command."

Dangers of translations.

Custom of the country regarding fixed prices.

Illustrations and engraving.

Commercial artists, their quality, remuneration, etc.

Duties and formalities in sending plates or clichés prepaid. 
5. Advertising Rates:

Local and foreign rates.

Differences of opinion between foreign publishers and American advertisers.

Details of contract for advertising and the fulfillment of contracts.

6. Advertising Agencies:

Foreign advertising agencies.

Publishers' agents.

Standards of practice, if any.

The local situation.

Advertising agencies in the United States.

Need of coöperation for united effort in foreign fields.

(The general function of the advertising agency should be entered into here.)

7. Public Conveyances:

Street-car, subway and other public-conveyance advertising.

Kinds of posters and cards displayed.

Sizes of cards or posters.

Location.

Uniformity of frame or board, or lack of uniformity.

8. Outdoor Advertiging:

Railway station advertising.

Handbills.

Posters on walls.

Billboards'.

Regulations governing pasting of bills, if any.

Electric signs.

Norelties.

Use of novelties, calendars, and other specialties.

9. Trade-Marks and Copyrights:

The necessity of protecting trade-marks and copyrights in foreign countries.

International Trade-mark Bureau of Havana.

Methods of procuring trade-marks and copyrights.

10. Direct-by-MaIl Methods:

Preparation of sales letters.

Postage.

Duties on letters or catalogues in bulk.

Use of parcel post.

Use of form letters.

Directories and mailing lists. 


\section{Catalogues:}

The foreign language eatalogue.

The necessity of care to assure expert translations.

Polyglot of many catalogues.

Bi-lingual catalogues.

The policy of printing prices in the catalogue, and other details of this nature.

12. american Export Trade Journals as Media. (See particularly Cuban Reports.)

13. Motion Pictures:

Industrial films.

The possibility of this development.

The extent of the use of motion-picture houses, the nature of films shown, and the extent of the use of educational films in schools, churehes, lodges.

Motion pietures, as an outside or open-air media.

Although there seems to be no adequate book dealing with foreign trade advertising there is considerable material to be found in the following publications:

Advertising and Selling Practice, by Opdycke. A. W. Shaw Co.

Advertising Campaigns, by Martin. Alexander Hamilton Institute.

Advertising Principles, by De Bower. Alexander Hamilton Institute.

Those interested in the subject will be helped by reports of Mr. J. W. Sanger, trade commissioner of the U. S. Bureau of Foreign and Domestic Commerce relative to advertising in particular countries like Cuba, Chile, Peru, Bolivia, Argentina, Uruguay, Brazil and the Far East.

Those who are interested to get outline for either individual or course of study on other topies related to foreign commerce might get suggestions by reading the book entitled Training for Foreign Trade, Miscellaneous Series No. 97, by R. S. MacElwee and F. G. Nichols. This book may be had for 15 cents from the Superintendent of Documents, Government Printing Office, Washington, D. C. 


\section{SUGGESTED LIST OF BOOKS HELPFUL IN TRAINING FOR FOREIGN COMMERCE}

South America:

Adams, Frederick Upham: Conquest of the Tropics. (New York, 1914, Doubleday Page \& Co.)

Aughinbaugh, W. E.: Selling Latin America. (Boston, 1915. Small Maynard \& Co.)

Bingham, Hiram: Across South America. (New York, 1911, Houghton, Mifflin $\mathrm{Co}$.)

BRYCE, JAMES: South America: Impressions and Observations. (New York, 1917, Macmillan Co.)

Collins, James H.: Straight Business in South America.

(New York, 1920, D. Appleton and Co.)

Cooper, Clayton Sedgwick: Understanding South America.

(New York, 1918, George H. Doran Co.)

Exock, C. R.: The Republics of South and Central America. (New York, 1913, C. Scribner's Sons.)

Ford, IsAaC N.: Tropical America. (New York, 1893, C. Scribner's Sons.)

Garcia, Caldron, F.: Latin America: Its Rise and Progress. (New York, 1913, C. Seribner's Sons.)

Goldsyith, P. H.: A Brief Bibliography of Books in English, Spanish and Portuguese, relating to the Republics commonly called Latin America, with comments. (New York, 1915, Macmillan Co.)

Hinst, W. A.: A Guide to South America. (New York, 1915, Macmillan Co.)

JONES, Chester LLOYD: Caribbean Interests of the United States. (New York, 1916, D. Appleton \& Co.)

Koeber, W. H.: South America. (London, 1918, T. Fisher Unwin.)

-British Exploits in South America. (New York, 1917, Century Co.)

Latane, John H.: The Diplomatic Relations of the United States and Spanish America. (Baltimore, 1900, Johns Hopkins Press.)

MoORE, JoHn BassetT: American Diplomacy: Its Spirit and Achievements.

Mozans, H. J.: Up the Orinoco and Down the Magdalena. (New York, 1910, D. Appleton \& Co.) 
Paxson, F. L.: Independence of the South American Republicans.

Peck, Annie S.: The South American Tour. (New York, 1916, George H. Doran Co.)

Pepper, Charles M.: Panama to Patagonia. (New York, 1916, Young People Missionary Movement of the United States and Canada.)

Post, Charles Johnson: Across the Andes. (New York, 1912, Outing Publishing Co.)

Petre, F. L.: Simon Bolivar.

ReId, W. A.: Young Man's Chances in South and Central America.

Root, EurHu: Latin America and the United States. (Harvard University Press.)

Ross, E. A.: South of Panama. (New York, 1915, Century Co.)

RuHL, ARTHur: The Other Americas. (New York, 1908, C. Scribner's Sons.)

Savage-Lander, A.: Across Unknown South America, 2 vols. (Boston, Little, Brown \& Co.)

Sears, Anna Wentrwortir: Two on a Tour in South America. (D. Appleton \& Co.)

Shepherd, William R.: Latin America. (New York, 1917, Henry Holt \& Co.)

ShenIL, C. H.: Modernizing the Monroe Doctrine.

Shuer, H. S.: Bibliography of Foreign Trade Publications.

(San Francisco, 1918, Ten Bosch Co.)

S'Tephens, Henry: South American Travels.

Verrill, A. Hyatr: Getting Together with Latin America. (New York, 1918, E. P. Dutton \& Co.)

WHYMPER, EDWARD: Travels among the Great Andes of the Equator.

ZaHM, Rev. J. A.: Abong the Andes and Down the Amazon. (D. Appleton \& Co.)

-Through South America's Southland. (D. Appleton \& Co.)

-Up the Orinoco and Down the Magdalena. (D. Appleton $\&$ Co.)

It must be remembered that new books are being published frequently, and the student of South American conditions will naturally keep in touch with the reviews of these books in newspapers and magazines. 
The Pan-American Union publishes monographs and booklets from time to time covering each of the individual countries of South America as to population, trade statistics, races, etc. This literature can be acquired by writing to the Pan-American Union, Washington, D. C.

To those who would like to go more deeply into Latin American study and who would like to specialize somewhat along political lines, a supplementary list is given herewith emphasizing books on politics and travel:

Bates, Henry Walter: Naturalist on the Amazon River.

Bigelow, John: American Policy: The Western Hemisphere and its Relation to the Eastern. (New York, C. Scribner's Sons.)

BUCKMan, Williamson: Under the Southern Cross in South America. (New York Book Publishing Co.)

BULeY, E. C.: North Brazil. D. Appleton \& Co.

Bulex, E. C.: South Brazil. D. Appleton \& Co.

Davidson, N. J.: Romance of the Spanish Main. (Philadelphia, Lippincott Co.)

Enock, C. R.: The Tropics. (New York, C. Scribner's Sons.) Franck, Harry A.: Vagabonding Down the Andes. (Century Co.)

HatSey, Frederick M.: Railway Expansion in Latin America. (Moody Magazine and Book Co.)

Hart, ALbert Bushnell: The Monroe Doctrine (Boston, Little, Brown \& Co.)

Helps, Arthur: Life of Pizarro, with some accounts of his associates in the Conquest of Peru.

Holland, W. J.: To the River Plate and Back. (G. P. Putnam's Sons.)

Huld, William L.: The Monroe Doctrine: National or International. (G. P. Putnam's Sons.)

Johnson, Emory R.: The Panama Canal and Commerce. (D. Appleton \& Co.)

Jones, Chester Lloyd: Mexico and its Reconstruction (D. Appleton \& Co.)

JoycE, Thomas: South American Archaeology. (G. P. Putnam's Sons.)

MerRimin, R. B.: The Rise of the Spanish Empire in the Old World and the New. (Set of four volumes.)

Miller, Leo E.: In the Wilds of South America. 


\section{FOREIGN TRADE MARIETS AND METHODS}

\section{Europe:}

Alexinsky, Gregor: Russia and Europe. (New York, 1917, C. Scribner's Sons.)

Anderson, Isabeu: The Spell of Belgium. (Boston, 1915, Page Co.)

Baker, JaMes: Austria: Her People and their Homelands. (New York, 1913, John Lane.)

BARker, J. E.: Modern Germany. (New York, 1915, E. P. Dutton \& Co.)

Bell, A. F. G.: Portugal of the Portuguese. (New York, 1916, C. Scribner's Sons.)

Bensusan, S. L.: Home Life in Spain. (New York, 1910, Macmillan Co.)

BirminghaM, G. A.: Irishmen All. (New York, 1913, Stokes.) Boulger, D. C.: Holland of the Dutch. (New York, 1913, C. Scribner's Sons.)

BracQ, J. C.: France Under the Republic. (New York, 1910, C. Seribner's Sons.)

Brown, Cxril: Germany as It Is To-day. (New York, 1917, George H. Doran Co.)

Butler, RalPh: New Eastern Europe, The. (New York, 1919, Longmans, Green \& Co.)

ChapMan, C. E.: A Short History of Spain. (New York, 1918, Macmillan Co.)

Chenrezi, C. A.: Albania, Past and Present. (New York, 1919, Macmillan Co.)

Child, R. W.: Potential Russia. (New York, 1916, E. P. Dutton \& Co.)

Clark, F. E.: Old Homes of New Americans. (New York, 1913, Houghton Mifflin Co.)

Clark, F. E. AND S. A.: The Charm of Scandinavia. (Boston, 1914, Little, Brown \& Co.)

Colliter, Price: England and the English from an American Point of View. (New York, C. Scribner's Sons.)

- Germany and the Germans from an American Point of View. (New York, 1913, C. Scribner's Sons.)

Conwar, A. E.: A Ride Through the Balkans. (New York, 1017, Sturgis \& Walton.)

Coxwell, C. F.: Through Russia in War Time. (New York, 1916, C. Scribner's Sons.)

Drachmann, Poou: Industrial Development and Commercial 
Policies of the Three Scandinavian Countries. (New York, 1914, Oxford University Press.)

Ferriman, Z. D.: Greece and the Greeks. (New York, 1910, James Pott.)

Formax, H. J.: London: An Intimate Picture. (New York, 1913, McBride-Nast.)

Fox, Frank: England. (London, A. C. Black.)

-Switzerland. (London, 1914, A. C. Black.)

Garlanda, Federic0: The New Italy. (New York, 1911, G. P. Putnam's Sons.)

Gayda, Virginio: Modern Austria: Its Racial and Social Problems. (New York, 1915, Dodd, Mead \& Co.)

Gibbons, H. A.: Paris Reborn. (New York, 1916, Century Co.)

Gordon, Winifred: Rumania, Yesterday and Today. (New York, 1918, John Lane.)

Graham, Stephen: Russia and the World. (New York, 1917, Macmillan Co.)

GRIFFIS, W. E.: Belgium, the Land of Art. (Boston, 1912, Houghton Mifflin Co.)

-Bonnie Scotland and What We Owe Her. (New York, 1916, Houghton Mifflin Co.)

HAGGARD, H. R.: Rural Denmark and Its Lessons. (New York, 1911, Longmans, Green.)

Henderson, T. F. and Watt, Francis: Scotland of Today. (New York, 1907, James Pott.)

Hissey, J. J.: The Charm of the Road. (New York, 1910, Macmillan Co.)

Keynes, J. M.: Economic Consequence of the Peace. (1920, Harcourt, Brace and Howe.)

LEACH, H. G.: Scandinavia of the Scandinavians. (New York, 1915, C. Scribner's Sons.)

Levine, I. D.: The Resurrected Nations. (New York, 1919, Stokes.)

Logio, G. C.: Bulgaria's Problems and Politics. (London, 1919, William Heinemann.)

Lomas, JoHN: In Spain. (1908, Macmillan Co.)

LrDE, L. W.: The Continent of Europe. (New York, Macmillan Co.)

MacDonnell, J. 45 C.: Belgium, Her Kings, Kingdom and People. (Boston, 1914, Little, Brown \& Co.) 


\section{FOREIGN TRADE MARKETS AND METHODS}

Meldrum, D. S.: Home Life in Holland. (New York, 1911, Macmillan Co.)

Merriwether, Lee: Seeing Europe by Automobile. (New York, Baker \& Taylor.)

Monroe, W. S.: Bulgaria and Her People. (Boston, Page Co.) -In Viking Land. (Boston, 1910, Page Co.)

Nevill, Forbes; Toynbee, A. J.; Mitrany, D.; and Hogarth, D. G.: The Balkans. (New York, 1917, Oxford University Press.)

Nosek, V.: Independent Bohemia: An Account of the CzechoSlovak Struggle for Liberty. (London, 1918, J. M. Dent \& Sons.)

Peacock, Wadham: Albania, the Foundling State of Europe. (New York, 1914, D. Appleton \& Co.)

ReAde, Arthur: Finland and the Finns. (New York, 1917, Dodd, Mead \& Co.)

RIGGS, A. S.: France from Sea to Sea. (New York, 1913, McBride-Nast.)

Russelu, C. E.: Unchained Russia. (New York, 1918, D. Appleton \& Co.)

Sully, James; Italian Travel Sketches. (New York, 1912, C. Scribner's Sons.)

VANDERLIP, F. A.: What Happened to Europe. (New York, 1919, Macmillan Co.)

Vizetelly, E. A.: The True Story of Alsace-Lorraine. (New York, 1918, Stokes.)

Von Heidenstam, C. G.: Swedish Life in Town and Country. (New York, 1904, G. P. Putnam's Sons.)

Wallace, W. K.: Greater Italy. (New York, 1917, C. Scribner's Sons.)

WARD, C. H. B.: The Truth about Spain. (New York, 1911, Cassell.)

WebB, Frank: Switzerland of the Swiss. (New York, 1909, C. Scribner's Sons.)

WENDELL, BARRETT: The France of To-day. (New York, 1909, C. Scribner's Sons.)

-The Ireland of To-day. (Boston, 1915, Small, Maynard \& Co.) 


\section{The Near East:}

Babrieliax, M. C.: Armenia, A Martyr Nation. (New York, Fleming H. Revell \& Co.)

Cooper, Clayton Sedgwick: The Man of Egypt. (New York, George H. Doran Co., London, Hodder \& Stoughton.)

Cunningham, Alfred: Today in Egypt: Its Administration, People and Politics. (London, Hurst \& Blackett.)

Devine, Alexander: Montenegro in History, Politics and War. (New York, F. A. Stokes \& Co.)

Eversley, IORD: The Turkish Empire: Its Grouth and Decay. (London, T. Fisher Unwin.)

Hawlex, Walter A.: Asia Minor. (New York, John Lane Co.)

Hazen, Charles Downer: Fifty Years of Europe, 1870-1919. (New York, Henry Holt \& Co.)

Lazarovitch-Hrebelianovich: Prince, with collaboration of Princess. The Servian People: Their Past Glory and Their Destiny. (New York, C. Seribner's Sons.)

Lukach, Harry C.: The Fringe of the East. (New York, Macmillan Co.)

MarriotT, J. A. R.: The Eastern Question: A Historical Study in European Diplomacy. (New York, Oxford-Clarendon Press.)

MLartin, Percy F.: Greece of the Twentieth Century. (London, T. Fisher Unwin.)

Miltrany, D.: Roumania: Her History and Politics. (Oxford Unicersity Presis.)

Nweera, Samuel K.: Persia, the Land of the Magi. (Philadelphia, John C. Winston Co.)

Sloane, Wr. M.: The Balkans: A Laboratory of History. (Abingdon Press.)

Stetson-Watson, R. W.: The Rise of Nationality in the Balkans. (London, Constable \& Co.)

TAYLOR, A. H. E.: The Future of the Soutern Slavs. (London, T. Fisher Unwin.)

Woods, Henry C.: The Cradle of the War: The Near East and Pan-Germanism. (Boston, Little, Brown \& Co.)

The Far East (General):

Colemax, Frederick: The Far East Unveiled. (Houghton Miffin Co.) 
Cooper, Clatton Sedgwick: The Modernizing of the Orient. (New York, MeBride, Nast \& Co.; London, T. Fisher Unwin.)

Eldridge, Frank R. JR.: Trading With Asia. (D. Appleton \& Co.)

Fletcher, B. C. B.: The Problem of the Pacific. (New York, Henry Holt \& Co.)

Gibbons, Herbert Adanss: The New Map of Asia. (New York, Century Co.)

Hornbeck, Stanley K.: Contemporary Folitics in the Far East. (New York, D. Appleton \& Co.)

Hrndman, H. M.: The Awakening of Asia. (New York, Boni \& Liveright.)

Kaisha, Osaka Shosen: Guide to the Orient. (Osaka Mer. cantile Steamship Co., Osaka, Japan.)

Millard, T. F.: Democracy and the Eastern Question. (New York, Century Co.)

Scholefield, G. H.: The Pacific: Its Past and Future. (New York, C. Scribner's Sons.)

Spalding, W. F.: Eastern Exchange Currency and Finance. (Isaac Pitman's Sons.)

-Trading with the Far East. (Irving National Bank.)

China and Japan:

Anderson, L.: The Spell of Japan. (Boston, Page Co.)

Asakawa, K.: Japar. (P. F. Collier \& Son.)

Bell, H. T. M. AND Woodhead, H. G. W., editors: China Year Book for 1919-1920. (New York, E. P. Dutton \& Co.) Brinkley, CApt. F.: A History of the Japanese People. (New York, George H. Doran Co.)

Cheng, Sih-gung: Modern China, A Political Study. (Oxford University Press.)

ClaAk, J. I. C.: Japan at First Hand. (New York, Dodd, - Mead \& Co.)

Crow, CaRL: Japan and America. (MeBride \& Co.)

Dewey, JoHN: Letters from China and Japan. (New York, E. P. Dutton \& Co.)

Greenbie, Sydney P.: Japan, Real and Imaginary. (New York, Harper \& Bros.)

Hershey, S. W.: Modern Japan. (Bobbs-Merrill Co.)

Huang, F. W.: Public Debts in China. (New York, Longmans, Green \& Co.) 
Kawskamr, K. K.: Japan and World Peace. (New York, Macmillan Co.)

- Japan in World Politics. (New York, Maemillan Co.)

- Japan and World Trade. (New York, Macmillan Co.)

Kirtland, Lucian S.: Samurai Trails. (New York, George H. Doran Co.)

LaMotte, Eluen: Peking Dust. (New Tork, Century Co.)

Latourette, K. S.: The Development of China. (Houghton, Mifflin Co.)

-The Development of Japan. (Houghton Mifflin Co.)

LiaNG, Y.: Village and Town Life in China. (London, G. Allen \& Unwin.)

Miller, G. A.: China Inside Out. (Abingdon Press.)

Overlach, P. W.: Foreign Financial Control of China. (New York, Macmillan Co.)

RoE, A. S.: Chance and Change in China. (New York, George H. Doran Co.)

Seaman, L. T.: From Tokyo Through Manchuria. (New York, D. Appleton \& Co.)

SeE, C. S.: The Foreign Trade of China. (New York, Longmans, Green \& Co.)

Tommas, S.: The Open Door Policy and the Territorial Integrity of China. (A. G. Seiler Co.)

Vinacke, H. M. : Modern Constitutional Development in China. (Princeton University Press.)

Weale, B. L. P.: The Truth About China and Japan. (New York, Dodd, Mead \& Co.)

Werner, E. T. C.: China of the Chinese. (New York, C. Scribner's Sons.)

Wheeser, W. R.: China and the World War. (New York, Macmillan Co.)

Korea:

Brown, Arthur J.: The Mastery of the Far East. (New York, C. Seribner's Sons.)

Chung, Henry: The Oriental Policy of the United States. (New York, Fleming H. Revell \& Co.)

Cynn, Hugh Hunng-Wo: The Rebirth of Korea. (Abingdon Press.)

McKenzie, F. A.: Korea's Fight for Freedom. (New York, Fleming H. Revell \& Co.) 
Philippine Islands :

Annold, J. R.: The Philippines, the Land of Palm and Pine. (An official guide and handbook.) (Manila.) Atrinson, F. W.: The Philippine Islands.

Ireland, Alleyne: The Far Eastern Tropics. (Houghton Mifflin Co.)

LeRox, James A.: The Americans in the Philippines. (Houghton Mifflin Co.)

Miller, Hugo H.: Economic Conditions in the Philippines. Report of the Governor General of the Philippine Islands to the Secretary of War (1917, Washington).

Worcester, Dean C.: The Philippines, Past and, Present. (New York.)

\section{India:}

Butler, Sir Harcourt: Indian Reforms, Imperial Idea and Provincial Progress, six speeches. (Calcutta, India, Government Press, United Provinces.)

Fuller: The Empire of India.

Ladd, George Trumbulu (R. Badger): Intimate Glimpses of Life in India.

Spens, A. B.: A Winter in India.

Elwin, E. F.: India and the Indians. (New York, 1913, C. Scribner's Sons.)

Fielding-Hall, H.: The Passing of Empire. (Boston, Houghton Miftlin Co.)

Graham, W. A.: Siam. (London, De La More Press.)

MALCOLM, IAN: Indian Pictures and Problems. (New York, 1907, E. P. Dutton \& Co.)

Murray: Handbook for Travelers in India, Burma and Ceylon.

(New York, C. Scribner's Sons.)

ReEs, J. D.: The Real India. (London, 1907, Menhuen.)

ScotT, Sir J. G.: Burma. (London, De La More Press.)

Strachey, Sir John: India, Its Administration and Progress.

(New York, 1911, Macmillan Co.)

Wright, ARnold \& Rein, T. H.: The Malay Peninsula. (New York, 1912, C. Scribner's Sons.)

-The Indian Empire. (New York, Oxford University Press.)

Dutch East Indies:

Cabaton, A.: Java, Sumatra and Dutch East Indies. (London, T. Fisher Unwin ) 
Dar, Olive: The Dutch in Java. (New York, Macmillan Co.) De Witt, Augusta: Java, Facts and Fancies. (Philadelphia, Lippincott.)

Kartini, Raden Aljeng: Letters of a Javanese Princess, translated from the original Dutch by Agnes L. Symmers. (Alfred A. Knopf.)

Canada:

Curran, W. T. \& Calkins, H. A.: In Canada's Wonderful Northland. (New York, 1917, G. P. Putnam's Sons.)

Goodrich, J. K.: The Coming Canada. (Chicago, 1913, McClurg.)

LAUT, A. C.: The Canadian Commonwealth. (Indianapolis, 1915, Bobbs, Merrill Co.)

Miller, J. O.: The New Era in Canada. (New York, 1917, E. P. Dutton \& Co.)

Wood, R. K.: The Tourist's Maritime Provinces. (New York, 1915, Dodd, Mead \& Co.)

Australia:

Duncan, Norman: Australian Byways. (New York, 1915, Harper.)

Fitchetт, W. R.: The New World of the South. (New York, 1913, C. Scribner's Sons.)

Fraser, J. F.: Austratia: The Making of a Nation. (New York, 1910, Cassell.)

Scholefiedi, G. H.: New Zealand in Evolution. (New York, 1909, C. Seribner's Sons.)

Scott, ERnest: A Short History of Australia. (New York, 1916, Oxford University Press.)

Africa:

Bryce, James: Impressions of South Africa. (New York, 1900, Century Co.)

Lorimer, Nonma : By the Waters of Africa. (New York, 1917, Stokes.)

Worsford, W. B.: The Union of South Africa. (Boston, 1913, Little, Brown \& Co.)

West Indies:

Ober, F. A.: A Guide to the West Indies and Bermudas. (New York, 1914, Dodd, Mead \& Co.)

Pitman, F. W.: The Development of the British West Indies, 1700-1763. (New Haven, 1917, Yale University Press.) 
Treves, Sir Frederick: The Cradle of the Deep. (New York, 1908, E. P. Dutton \& Co.)

Verrill, A. H.: Isles of Spice and Palm. (New York, 1915, D. Appleton \& Co.)

-The Book of the West Indies. (New York, 1917, E. P. Dutton \& Co.)

General Commerce:

Brown, H. G.: Principles of Commerce. (New York, Macmillan Co.)

Frlsinger, E. B.: Exporting to Latin America. (New York, 1916, D. Appleton \& Co.)

FORD: Foreign Trade of the United States.

Hough, B. Olney: Practical Exporting. (New York, 1919, Johnson Export Publishing Co.)

MarshaL: Industry and Trade.

Moore, J. T. M. : American Business in World Markets. (New York, 1919, George H. Doran Co.)

Pepper, Charles M.: American Foreign Trade. (New York, 1919, Century Co.)

Prectado, A. A.: Exporting to the World. (New York, 1919, J. A. MeCann.)

Savax, Norbert: Principles of Foreign Trade. (Ronald Press.)

Wolfe, A. J.: Theory and Practice of International Commerce. (New York, 1919, International Book Co.)

Foreign Exchange and Banking:

Clare, G.: A. B. C. of Foreign Exchange. (New York, 1911, Macmillan Co.)

Escher, Franklin: Elements of Foreign Exchange. (New York, 1917, Bankers Publishing Co.)

-Foreign Exchange Explained. (New York, 1917, Macmillan Co.)

Gonzales, V.: Modern Foreign Exchange. (New York, 1914, C. S. Hammond Co.)

Goschen, G. J.: Theory of the Foreign Exchanges. (New York, C. Scribner's Sons.)

JoHnson \& Huebner: Principles of Foreign Exchange.

Kniffin, W. E.: Practical Work of a Bank.

Margraff, A. W.: International Exchange. (Chicago, 1912, Fergus Printing Co.) 
Moone, W. U.: Law of Commercial Paper. (New York, 1916, D. Appleton \& Co.)

Shugrue: Problems in Foreign Exchange.

Spalding, W. E.: Eastern Exchange, Currency and Finance. (New York, 1917, Pitman \& Sons.)

-Foreign Exchange and Foreign Bills. (London, 1918, Pitman \& Sons.)

Stewart-Patterson, E. L.: Domestic and Foreign Exchange. Todd, JoHs A.: Mechanism of Exchange. (Loudon and New York, 1917, Oxford University Press.)

Whitaker, A. C.: Foreign Exchange. (D. Appleton \& Co.)

Withers, H.: International Finance and Trade. (New York, 1916, E. P. Dutton \& Co.)

-Meaning of Money. (New York, 1916, E. P. Dutton \& Co.)

-Money Changing. (New York, 1913, E. P. Dutton \& Co.)

- War and Lombard Street. (New York, 1915, E. P. Dutton \& Co.)

Wolfe, O. H.: Practical Banking. (Chicago, 1917, La Salle Extension University.)

York, Thouras: Foreign Exchange: Theory and Practice. (New York, 1920, Ronald Press.)

Shipping:

ClaRk, A. H.: Clipper Ship Era. (New York, 1918, G. P. Putnam's Sons.)

DE HAAS, J. A.: Foreign Trade and Shipping.

Hough, B. Olney: Ocean Traffic and Trade. (Chicago, 1914, La Salle Extension University.)

Huebner, G. G.: Ocean Steamship Traffic Management. (New York, 1920, D. Appleton \& Co.)

Hutchinson, Lincols: Panama Canal and International Trade Competition. (New York, 1915, Macmillan Co.)

Johrson, E. R.: Panama Canal and Commerce. (New York, 1916, D. Appleton \& Co.)

Johnson, E. R. \& Huebner, G. G.: Principles of Ocean Transportation. (New York, 1918, D. Appleton \& Co.)

MacElwee, R. S.: Ports and Terminal Facilities. (New York, 1918, McGraw, Hill Co.)

Martin, C. C.: Export Packing. (New York, 1912, Johnson Export Publishing Co.)

Meeker, Royal: History of Shipping Subsidies. (New York, 1905, Macmillan Co.) 
Owes, Douglas: Ocean Trade and Shipping. (New York, 1914, G. P. Putnam's Sons.)

SMITH, J. RUSSELL: Influence of the Great War upon Shiping. (New York, 1919, Oxford University Press.)

-Organization of Ocean Commerce. (New York, 1905. D. Appleton \& Co.)

Stevens, R. W.: Stowage of Ships and Their Cargoes. (London, Longmans, Green \& Co.)

ZimmermanN, Erich W. and Clark, M. C.: Foreign Trade and Shipping. (New York, 1917, Alexander Hamilton Institute.)

Marine Insurance:

Baty, T.: Britain and Sea Law. (London, 1912, Bell \& Sons.) Congdon, Ernest W.: General Average, Its Principles and Practice in the United States. (New York, 1913, Baker, Voorhis \& Co.)

De Hart, E. L. And Simey, R. I.: Armould on the Law of Marine Insurance and Average. (London, 1914, Stevens and Sons, Ltd.)

Duckworth, Lawrence: Principles of Marine Law. (London, 1916, Pitman \& Sons.)

Hunbner, S. S.: Marine Insurance.

-Property Insurance. (New York, 1911, D. Appleton \& Co.) Marsden, R. G.: Collisions at Sea. (Boston, 1911, Little, Brown \& Co.)

Poor, Wharton: Charter Parties and Ocean Bills of Lading. (Albany, N. Y., 1920, Matthew Bender and Co.)

Commentaries on the Law of Insurance. (Houghton Miflin Co.) 


\section{CHAPTER VII}

AMERICAN SHIPPING AND OUR NEW MERCHANT MARINE

At last the present American generation scems fairly waking up to realize the truth of the words of Sir Walter Raleigh :

Whosoever commands the sea commands the trade of the world; whosoever commands the trade of the world commands the riches of the world; and consequently the world itself.

It seems difficult to believe that for forty years, from 1789 to the year 1831, American ships carried an average of 90 per cent of the forcign commerce of the United States. In the year 1826 they carried as high as 92.5 per cent, the largest portion ever borne under the American flag in any year, at least up to the opening of the World War. It was at this time that Daniel Webster said :

We have a commerce which leaves no sea unexploited; navies which take no law from superior forces.

What was the explanation of this early interest of Americans in maritime pursuits?

It was the realization expressed by Thomas Jefferson as Secretary of State in 1793. Speaking of navigation he said:

Its value as a branch of industry is enhanced by the dependence of so many other branches upon it. In times of general peace it multiplies competitors for employment in transportation, 
and so keeps that at its proper level and in times of war, that is to say, when those nations who may be our principal carriers shall be at war with each other, if we have not within ourselves the means of transportation, our produce must be exported in belligerent vessels, at the increased expense of war freight and insurance, and the articles which will not bear that must perish on our hands.

America's first merchant marine came because of the dire necessity of the times. Foreign ships had flooded the country with foreign manufactures. We were not able to export produce sufficient to pay for our imports. The specie of the country was swept away and the national debt was growing. It was difficult for skilled labor to find employment and the nation was threatened with misery. The very independence of the new country seemed about to be abrogated.

The Congress that met in 1789 was a notable one, for it passed a tariff act which Washington signed July 4, 1789, containing the first American declaration of duty on imports in American vessels, and favored American ships in the carriage of tea from the ports of the Orient. This tariff stimulated tremendously home production. Industries became diversified and flourished, affording profitable employment for all. The country's specie returned, manufactures flourished, shipbuilding eame by leaps and bounds, and the new republic was crowned with prosperity throughout all its borders.

Up to this time only 23.8 per cent of the imports and exports of the United States was carricd in American ships. Before the new law had been working five years American ships were carrying 90 per cent of these imports and exports. The act was amended about this time and, instead of a reduction of duty in favor of American vessels, an increase of 10 per cent was imposed on all imports in foreign boats. These were red letter years of maritime history in the United States. The intervening years between 1831 and the present day are not intended to give an American a happy quarter of an hour. 


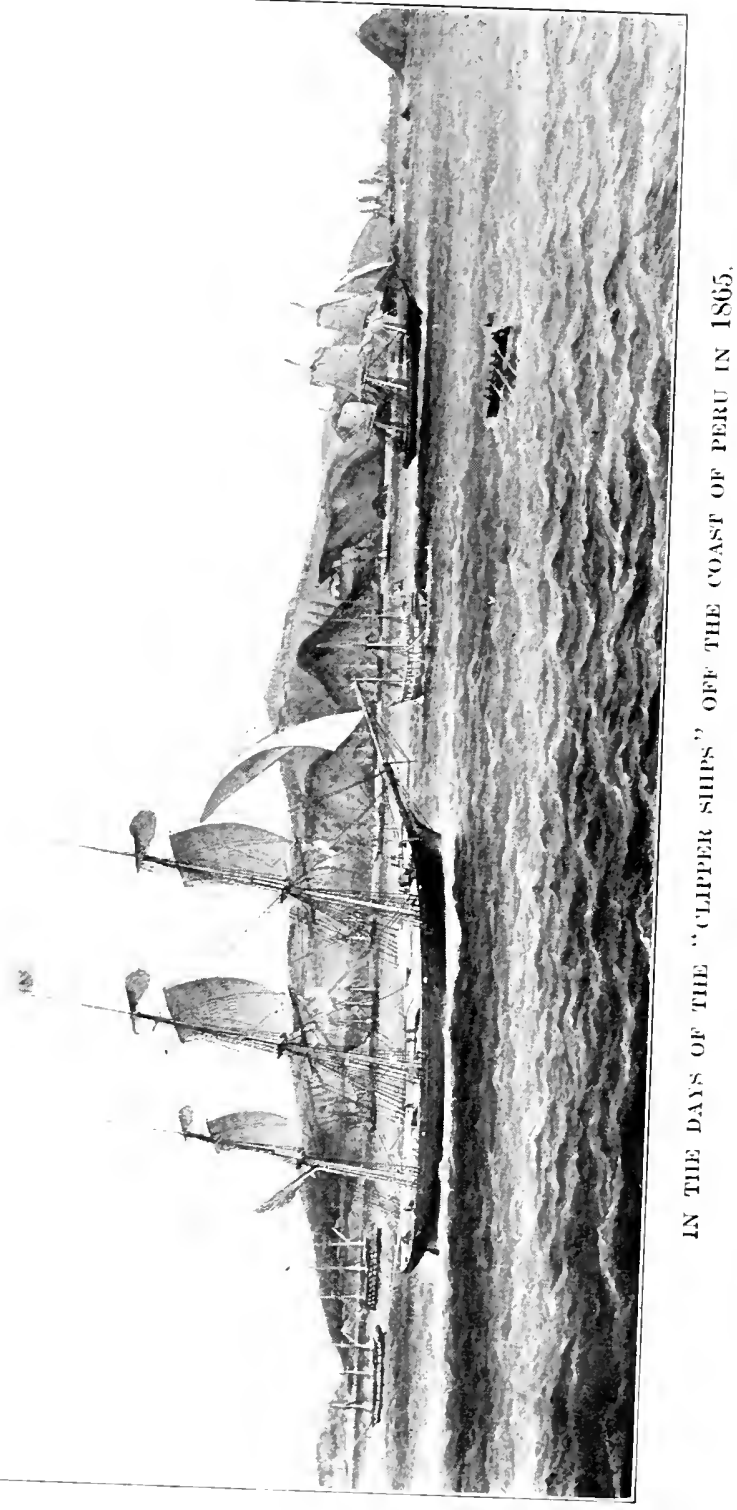




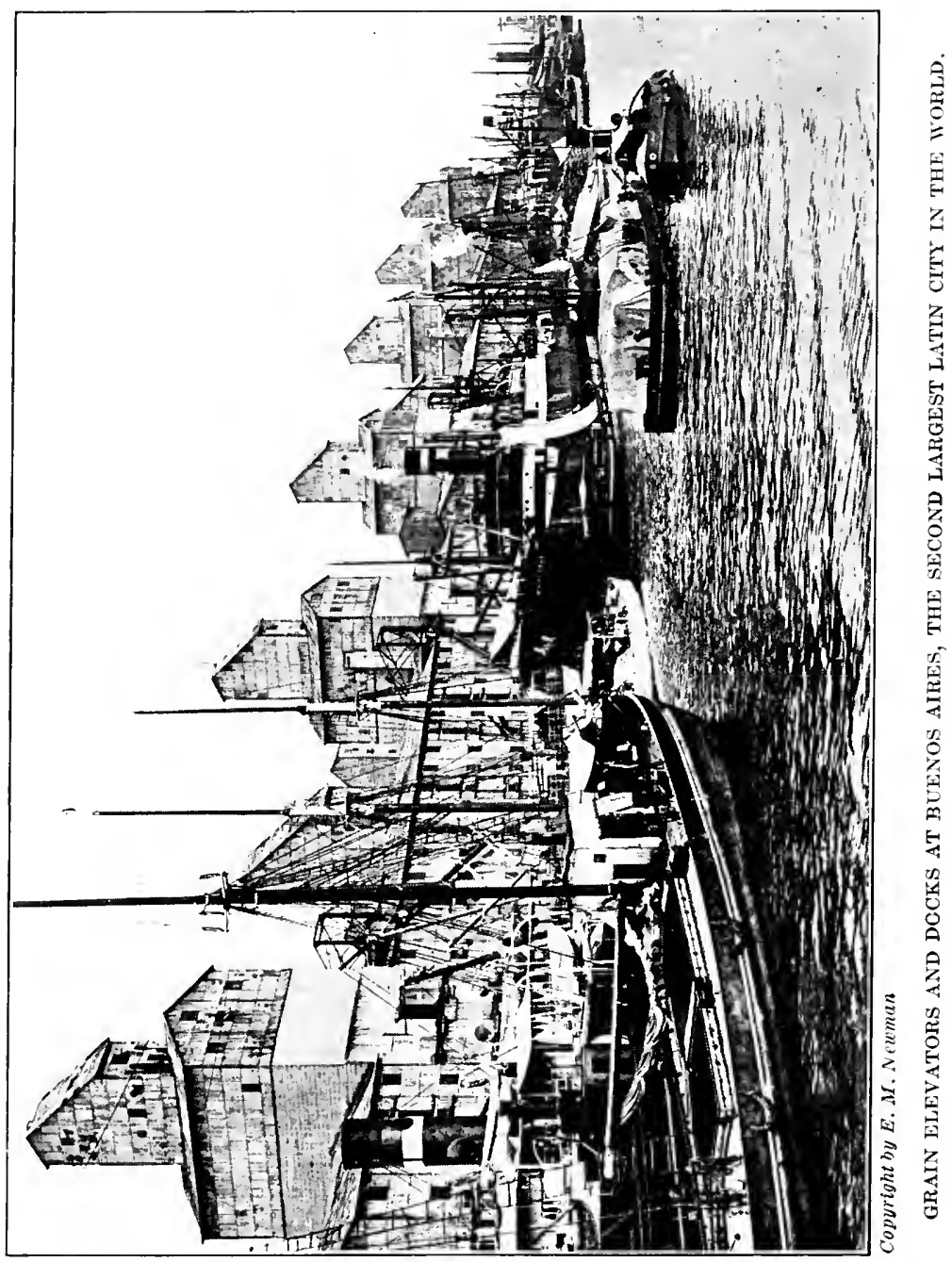


During the last twenty years, previous to 1914, instead of 90 per cent of our foreign trade being carried in Ameriean owned and operated ships, American vessels earried an average of less than 10 per cent of such products, and this in spite of the fact that our exports have grown from $\$ 71,670,735$ in 1830 to $\$ 2,364,579,148$ in 1914 , and imports during the same period increased from $\$ 62,360,956$ to $\$ 893,926,657$. In 1810 the eubic feet of investment in American shipping per capita was 13.55 cubic feet; in 1910 it was only .85 cubic feet. In other words, previous to the European war, our commerce was practically given over to foreigners to transport and the loss to the country has been tremendous.

These are facts of deep significanee, not simply to shipbuilders and politicians, but to the average laborer and the citizen of whatever class, because it has been proved beyond the shadow of a doubt that a great shipbuilding program stimulates virtually every industry of a nation, and assures certainty of continuous employment and a steady manufacture.

Consider, if you are skeptical about the necessity of an American merchant marine, these facts!

For the twenty-year period ending in 1914 our total overseas commeree amounted to nearly $\$ 5,000,000,000$, an increase of $783 \% \mathrm{~s}$ per cent over the previous twenty years. In the carrying of this commerce American ships earned a little less than $\$ 300,000,000$, and foreign ships more than $\$ 2,500,000,000$.

Let foreign trade inerease at the same rate during the next twenty year's and it would amount to $\$ 89,000,000,000$ which would mcan, providing the United States decided not to have a merchant marine, that we would give over to foreign nations and their merchant marines $\$ 5,000,000$,000 in freight charges alone. Nor does this startling fact take account of the millions earned every year by foreign ships carrying our passengers and mails; nor do the figures include the enormous profits on the cost of repairs, wages, stores, etc., now paid into foreign treasuries. 
It has been carefully estimated that the American nation has bought and paid for in the past twenty years in freight charges alone the equivalent of $26,965,692$ tons of shipping, more than the world's total tonnage at the outbreak of the war. And if our former lethargy regarding these matters continues during the next twenty years we shall proceed to pay in freight charges to foreign nations for 48,088,589 tons of shipping.

Until the war awakened the nation to these grave conditions all efforts of organizations and loyal citizens and manufacturers have been in vain. The Midale West has said :

Oh, ships? That is a matter for shipbuilders and the people in the seaport states in the East. We can get our goods carried in foreign bottoms and why should we worry?

The politician has eared little and known less about foreign trade and foreign nations. 'The country was so busy in a mieroseopic policy of home industry that it lost its perspective upon world affairs. American travelers have returned to the country to report that they have found in foreign ports the ships of every other nation under the sun, save those of the United States. The following words of Lewis Nixon are a sample of the warning and pleas given forth without impression upon the average Ameriean.

A glance at the harbor in New York will show great fleets of ships constantly added to by more and larger boats, which were built from the earnings of our country and constantly growing in earning power. There is plenty of profit if we can get into the business. At the present time we are faced upon the ocean by a monopoly of ocean earriers, together with inordinate naval powers; yet the very men who rail against domestic monopoly not only fail to appreciate this great menace to our national prosperity, but actually belittle the efforts of those who are attempting to awaken our people to a realization of it.

That whieh the efforts of many a well-wisher of our maritime independenee found it impossible to bring about 
has come along with the war and the particular emphasis that this eonflict laid upon the need of shipping.

The leadership of the United States Shipping Board, supported by thousands of shipbuilders and their employees, newly enlisted in this fresh industr'y, has aroused a hope that after all these years the United States may see its flag upon the ships of the seven seas.

In order to reveal this new interest of the United States in shipping matters, it will be of interest to study a few maritime facts.

Merehant fleets of the world at the end of June, 1914, totaled approximately $35,000,000$ gross tons in ocean-going steamers of 1600 gross tons or more. There was in addition to this tonnage approximately $7,000,000$ tons made up of smaller steamers from 100 to 1600 gross tons in size. The following table gives an idea of the way this tonnage was distributed among the different nations:

World's Merchant Steam Tonnage for June 30, 1914

\begin{tabular}{|c|c|c|}
\hline Country & $\begin{array}{c}1600 \text { Gross Tons } \\
\text { and Over }\end{array}$ & $\begin{array}{l}100 \text { Gross Tons } \\
\text { and Over }\end{array}$ \\
\hline 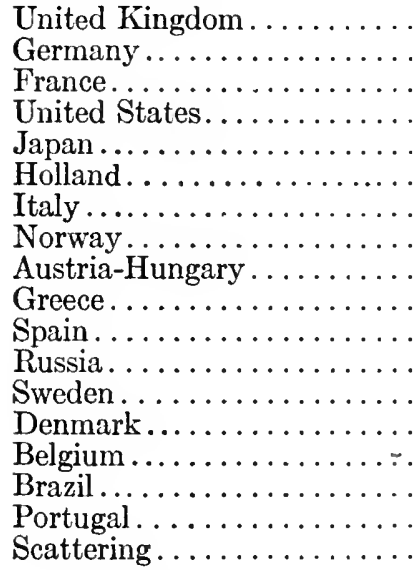 & $\begin{array}{r}17,465,000 \\
4,650,000 \\
1,645,000 \\
1,520,000 \\
1,400,000 \\
1,275,000 \\
1,250,000 \\
1,125,000 \\
950,000 \\
725,000 \\
700,000 \\
585,000 \\
545,000 \\
455,000 \\
285,000 \\
150,000 \\
50,000 \\
360,000\end{array}$ & $\begin{array}{r}20,100,000 \\
5,150,000 \\
1,920,000 \\
1,875,000 \\
1,750,000 \\
1,475,000 \\
1,430,000 \\
1,950,000 \\
1,950,000 \\
820,000 \\
900,000 \\
850,000 \\
1,030,000 \\
785,000 \\
345,000 \\
300,000 \\
90,000 \\
795,000\end{array}$ \\
\hline Total. & $35,135,000$ & $42,615,000$ \\
\hline
\end{tabular}


It will be seen from these figures that out a total of $35,000,000$ tons all but 500,000 tons was owned by fifteen countries and, furthermore, that the bulk of the world's steam tonnage in 1914 belonged to eight nations. The United Kingdom, with more than 17,000,000 tons; Germany, with 4,500,000; and the other six-France, the United States, Japan, the Netherlands, Italy and Norway -ranging between 1,000,000 and 2,000,000 tons each, controlled approximately 85 per cent of the ocean-going steamships of the world. It is quite clear, therefore, that the burden of maritime transport and the losses sustained fell prineipally on these nations. The dominant place of British shipping and the weak position of the United States was evident.

During the war the allied and neutral fleets suffered heavily and the combined efforts of the enemies of the allies cut deeply into the tonnage especially of Great Britain and France. Great Britain lost more tonnage during the war than was owned by any two other nations at the outbreak of the war. The losses of the United States were relatively less than those of the other allies and less than some of the neutrals, especially Norway, Sweden and Denmark. This was due in part to the small merchant fleets which our country owned during the war and in part because of our late entry into the conflict. A further reason might be attributed to the fact that there was less need for United States ships to cross the submarine zone. The total losses estimated from enemy operations during the war were $13,000,000$ gross tons.

In the following table are included the losses of all sizes and classes of vessels, but mainly of seagoing steamers. Add to these losses from marine risk, about 2,200,000 tons and the total comes up to $15,000,000$ gross tons of loss during the war period or about 35 per cent of the world's tonnage of all sizes and classes when the war opened. It may be noted that losses from marine risk averaged normally about $21 / 2$ per cent a year, and while the war was in progress losses from all causes oecurred 
at more than three times this normal rate. If there had not been a speeding up of shipbuilding during this period, replacing losses by new construction, the world's fleets would have decreased by about one-third.

Allied and Neutral Losses of Merchant Tonnage

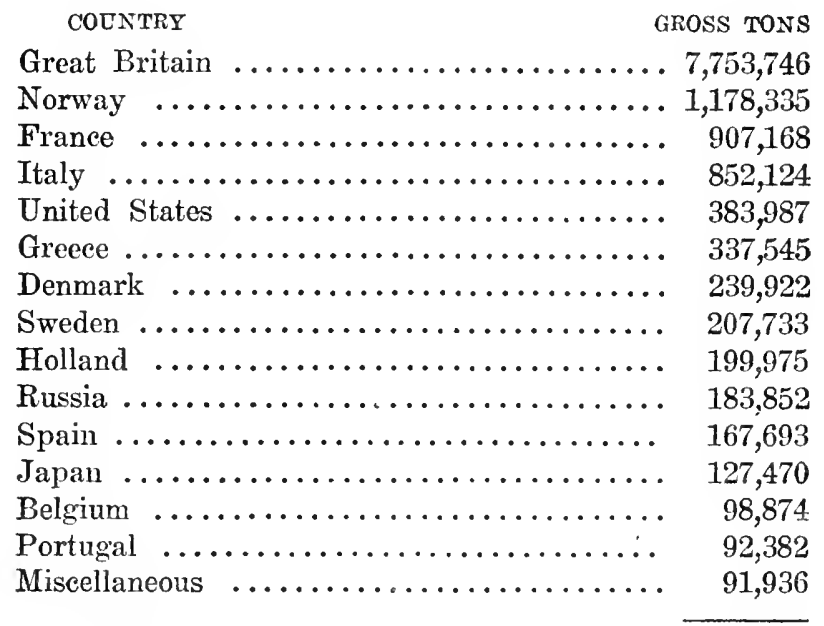

Total

$.12,814,742$

The war developed in the United States a ncw vigor of shipbuilding, and ships which take from one to three years to complete in peace time were built in a few months and in some cases in a few weeks even, during much feverish activity. This period was marked by the standardization of vessels and by a nation-wide mobilization of industrial resources for the purpose of speeding up ship construction. The total construction for the war period amounted to nearly $12,000,000$ gross tons. The following table will give an idea of the annual construction of vessels for three momentous years in shipbuilding industry on the part of the principal shipbulding nations: 
Shipbuilding in the Principal Cotntries, 1916 to 1918

\begin{tabular}{|c|c|c|c|}
\hline & $\begin{array}{c}\text { Gross Tons, } \\
1918\end{array}$ & $\begin{array}{c}\text { Gross Tons, } \\
1917\end{array}$ & $\begin{array}{c}\text { Gross Tons, } \\
1916\end{array}$ \\
\hline 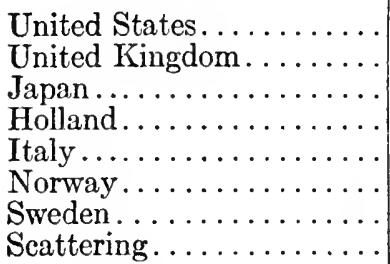 & $\begin{array}{r}3,033,000 \\
1,348,100 \\
489,900 \\
74,000 \\
60,700 \\
47,700 \\
39,500 \\
354,500\end{array}$ & $\begin{array}{r}997,900 \\
1,348,100 \\
350,100 \\
148,700 \\
38,900 \\
46,100 \\
26,700 \\
166,600\end{array}$ & $\begin{array}{r}504,200 \\
608,200 \\
145,600 \\
180,100 \\
56,600 \\
42,400 \\
26,700 \\
124,300\end{array}$ \\
\hline World total.. & $5,447,400$ & $2,937,800$ & $1,688,100$ \\
\hline
\end{tabular}

The above figures not only reveal a great increase in total tonnage built, but they show the United States in a leading position in this recent construction period. Our country has increased its output sixfold in three years and the total of more than 3,000,000 tons of shipbuilding in 1918 was greater than all the world had built in the preceding year. Japan increased its output threefold, while Great Britain produced less tomnage than in prewar years, because of the fact that so many of her yards were required for naval craft. At the end of 1918 the world's merchant fleet of ocean-going steamships (1600 tons and over) totaled about $32,600,000$ gross tons.

The relative importance of the principal nations which control the world's merchant marine has thus altered considerably during the past four or five years, the United Kingdom still leading with more than 14,000,000 tons and the United States with upwards of $6,000,000$ tons taking second place. The four leading maritime eountries to-day are the United Kingdom, the United States, Japan, Franee. These four and their eombined fleets own upwards of 75 per eent of the world's tonnage. By the end of the present year the United States should have adequate shipping to carry at least 50 per cent of its overseas trade and, if legislation and leadership are fortheoming, our country 
should really start upon a new period of shipping history. It must be remembered, however, that the British fleet is rapidly being enlarged and is still the leading merchant fleet of the world, and promises to remain in this leadership, since Great Britain is so vitally dependent upon the sea and ships for its expansion and livelihood.

The great need at present in our eountry is for definite and decisive action relative to laws by Congress that will make it possible for our country to compete on even terms with other nations on the sea.

There is, however, a kind of indefiniteness about all of our plans which troubles the practical and experienced shipowner and manufacturer. Our maritime affairs are somewhat like the deseription of an old darky woman of her husband's illness. When asked how her man was getting on, she replied:

Oh, he's just lingering along, lingering along. I do wish he would do something definite.

Doubt is expressed by many of our most capable shipping men as to our aetual ability to compete with Oriental ship labor, and there is also doubt as to whether this country ean build ships cheaper than those eonstrueted on the Clyde. There is still also uncertainty as to the best method of operation of our ships.

Shall the government own and operate the vessels? Should ships be owned and run by private firms? Shall the ships be sold at auction? Or shall we follow the suggestion of a former vice-president of the Emergency Fleet Corporation, who believes that the government should treat the ships as New York City treats the subways-own them and lease them to private operators?

The very evident tendeney at present both on the part of the Shipping Board and shipping men generally is toward the private operation at least of our merehant marine, while there are rumors occasionally of subsidies together with new ideas of ownership and operation more or less eonstantly fortheoming. 
Whatever plan is adopted the country faces an intricate problem, and this problem revolves about economic advantage and possibility.

Robert Dollar, the veteran shipowner, sees the problem from the point of view of owners of ships and believes that these men alone must be held responsible to develop trade. He says that ship charterers having no money invested will operate the ships only as long as they ean make a profit.

Mr. Dollar further advocates the selling of the ships by the government to private owners on the installment plan; he would also like to have the government pay the difference between the Ameriean standard wage, say $\$ 60$ a month, and the Oriental standard pay of perhaps $\$ 15$ a montl.

Then, again, the ever present Seamen's Act rises to the surface, and there is a consensus of opinion, rather than a consensus of acts, to the end that certain portions of this bill at least should be radically ehanged, if American ships are to be placed again on the Pacific in competition with Japanese earriers.

Add to these walls of diffieulty a slow-moving and, if we are to judge from the past, an ill-intormed Congress, more or less indifferent to all matters outside the eonfines of the United States, and the need beeomes more and more pressing for some decisive and experieneed leadership.

A statement by the National Foreign Trade Council, of which Mr. James A. Farrell is Chairman, offers specifie suggestions for handling the shipping problems:

Congress has declared in favor of private ownership of our merchant marine as soon as practicable, but under present conditions it is impracticable to dispose of any considerable proportion of our merchant marine to private owners at fair prices.

So much of the fleet as cannot be chartered on a bare boat basis or time charter to private operators should be laid up 
pending the revival of world commerce. Meanwhile the fleet will serve our national security as a naval anxiliary in case of necessity.

The plan should be abandoned of allocating ships to load at ports and for trade routes irrespective of the tonnage of cargo offering or of the losses to the Government attendant on this policy.

While it is obvious that the ultimate sale price will be measured by the world market for similar ships, such parity of price and successful operation can be obtained only if the operating costs arc approximately equal to those of our foreign competitors.

Present shipping laws requiring larger crews subject American vessels to a disadvantage estimated at 5 per cent on the capital investment, while the compulsory advance of half wages in any foreign port of call adds a further burden of cost by involving excessive delays.

As continued maintenance of the American merchant marine is of vital interest to American producers, exporters and importers, they should require the employment of American vessels in the carrying of their shipment of exports and imports to such extent as they are able to exercise preference or control, and in any case they should prevent discrimination against American ships in such transportation.

It is believed that the adoption of these recommendations will save the Gorernment its present large loss in carrying on the existing plan of operation and will insure vltimately the retirement of the Government from the shipping business through the sale to private owners of the fleet at reasonable prices.

Between the United States and its possessions and foreign ports, rapid, regular combined passenger and freight service should be maintained for the prompt and regular carriage of the mails, express, freight and merchandise.

The State and Federal governments are urged to remore those disabilities caused by nonuniformity of State laws and excessive taxation which place American insurance at a disadvantage with the foreign insurance market in which they must compete. We urge the enactment of the marine insurance measure now pending in Congress, a model upon which uniform State legislation may be based.

American export business has been injured in the past by lack of persistent effort to hold markets already gained. American producers are urged not to abandon or lose interest in their 
foreign trade because it shows no profit for the moment and to remember that in many cases it will cost much more to regain in the future a business lost now through lack of courage and foresight.

The vast market which the United States offers to other nations on a basis of equality, and the supplies of American raw material exported without taxation or discrimination, entitle the American export and import trade to equality of treatment in all foreign markets.

To insure such equality of treatment that American tariff whatever its underlying principle, should provide for additional duties on imports from nations discriminating by tariffs or administrative practices against the trade of the United States.

A most crucial necessity exists for a strong, competent and well-informed leader of our merchant marine activities, a man with authority to act. We have had quite enough of talk and theory spinning. As an old college professor once said to a hesitating student:

Your greatest need at present is to go ahead and do something.

Public sentiment has been aroused; now let it be capitalized in definite action.

One of the requirements of the American nation just now is a man of achievement, big in vision and capable by experience to focus his theories upon a definite line of action, which we believe the country is reauy, as never before, to support.

The period of theoretical education is drawing to an end; both within and without the U. S. Shipping Board we have experienced quite enough of errors of inefficiency; under the guidance of clearly defined business principles and policies the nation must now launch out into maritime life or be satisfied to slip back into its former isolated nonmaritime condition. No one believes that we can or will do this, but the necessity is insistent upon the nation.

But behind the scenes the plan for world readjustment is being worked out-here and there we see indications 
of better days in changed and better trade relations, for us in these cloudy days to have the courage of our convictions, to retain the good sense of our better judgment, and by exercise and application of the principles of coöperative effort prepare for the day when the clouds shall clear away and we shall stand in the forefront of the nations controlling the commerce of the world.

The Disarmament Conferenee which is being held in Washington as this book is going to press gives promise of action which will affect favorably the American merchant marine and with the sympathetic attitude of the present administration to our national shipping, it is sincerely hoped that many of the problems which have confronted our maritime business may meet with satisfactory solution. 


\section{CHAPTER VIII}

\section{MARINE INSURANCE}

Insurance furnished by competitors can be used to comb the profits out of any trade.-Henry Evans.

Among the instrumentalities to promote and conduct forcign trade, the three vital factors, shipping, banking and insurance, must be carefully studied by the manufacturer or exporter. The history of overseas business, in Great Britain and Germany particularly, reveals the fact that it is through the successful union of these three factors that trade suecess is achieved. A study of these nations will also convince the student that it is extremely important for a nation doing foreign business to contro] each one of these agencies rather than depend upon foreign nations either for ships, banks or insurance. It is too much for human nature to expect that any competitor nation will treat American exporters with the same consideration that they would treat their own citizens or subjects.

It becomes, therefore, a part of the patriotic duty of Americans to care for and maintain the interest of the American marine underwriter.

Marine insurance has for its objective the distribution amongst a number of individuals losses which might be difficult for any one of them to bear singly. The idea has evolved considerably since its beginning in the twelfth and thirteenth centuries amongst the then flourishing Italian republics, and there has arisen the marine underwriter whose business it is to serve the needs of the insuring public, and to see to it that the various members of 
that public are charged with their proper cost of protection.

The purpose of the marine insurance company is to give, in the first place, absolute and unquestioned protection to all persons liable to suffer loss through perils of the seas; second, when such loss occurs to pay whatever loss the insured has sustained; and, third, to adjust the cost of this protection that it shall not be excessive as a whole, nor shall any one man pay more than his fair share.

Ocean carriers are in a somewhat different case as far as risks are concerned than are the railroads. Both by law and also by the contract provisions of their bills of lading, they have a greatly limited liability. The Harter Act, which was passed by Congress in 1893, fixes the obligations of a steamship company in the United States. In this act it is stated that:

If the owner of any vessel transporting merchandise or property to or from any port in the United States of America shall exereise due diligence to make the said vessel in all respects seaworthy and properly manned, equipped, and supplied, neither the vessel, her owner, or owners, agent, or charterers shall become or be held responsible for damage or loss resulting from faults or errors in navigation or in the management of said vessel, nor shall the vessel, her owner or owners, charterers, agent, or master be held liable for losses arising from damages of the sea or other navigable waters, acts of God, or public enemies, or the inherent defect, quality, or vice of the thing carried, or from insufficicney of package, or seizure under legal process, or for loss resulting from any act or omission of the shipper or owner of the goods, his agent or representative, or from saving or attempting to save, life or property at sea, or from any deviation in rendering such service.

In order to give a concrete idea of the common insurance clauses in use, we are taking the liberty to present the views and explicit definitions of Mr. Edward R. Hughes, who for many years has specialized in connection with the insurance of merchandise. 


\section{F. P. A. E. C.}

(Free of particular average English conditions)

Warranted free from P. A. unless general, or the ship be stranded, sunk, burnt, on fire or in collision.

When goods are insured with this clause underwriters are not responsible for partial damage (particular average) unless one of the above accidents oceurs, thereby breaking the warranty. Should the warranty be broken then any loss or damage is reeoverable irrespective of percentage. A policy accepted with these conditions should also carry a clause providing for payment of goods totally lost (case and contents) during shipment, transshipment or discharge.

$$
\text { "W. A.," "S. P. A.," "F. P. A., 3\%" }
$$

All goods shipped under deck (except as hereinafter specially provided for) are covered: free of average under three per cent, unless general or the vesisel be stranded, sunk, burnt, on fire or in collision; each interest and/or each invoice to be considered as if separately insured, and average payable, if required, on the whole or on each invoice, or on each description of goods therein, or in series in order of invoice as follows:

(Here follows the description of goods and the series on which underwriters agree to pay claims.)

The terms "with average," "Subject to Particular Average," "Free of Particular Average unless amounting to three per cent" are merely different ways of stating that underwriters will pay for partial loss due to a peril insured against, provided the damage amounts to three per cent franchise. It should be understood, however, that in case of general average or the vessel be stranded, ete., any loss oceasioned by sea peril is collectible irrespective of percentage. 


\section{"ON DECK"}

Shipments on deck: Warranted free of particular average unless the vessel be stranded, sunk, burnt, on fire or in collision, but including risk of jettison and washing overboard, irrespective of percentage.

Unless the warranty is broken underwriters are not liable for damage unless an entire package (case and contents) is washed overboard or jettisoned.

The clauses referred to above are those most commonly used, but the nature of the goods shipped is the factor in determining what form should apply. For instanee, fruit and vegetables (perishable of their own nature), cement, steel goods and such like merchandise, which are liable to particular average, are usually only written on F. P. A. terms, while dry goods, shoes and case goods of nearly every description are insured "Subject to Particular Average if amounting to $3 \%$ on each case or shipping package.",

Underwriters' Responsibility.-It is somewhat difficult to put into condensed form to what extent the policy covers, but for ordinary purposes of claim it is generally assumed that loss caused by sea water is collectible when insured S. P. A. provided the damage amounts to the percentage mentioned in the policy. On the other hand, unless special insurance has been taken out at an enhanced premium, damage due to breakage, leakage, fresh water and oil stains are not collectible unless there is direct evidence that the damage was eaused by stranding or collision.

Carriers' Responsibility.-When the carrier issues a bill of lading on merchandise without a notation of any damage, he is in duty bound to deliver in like good order and condition as reeeived, unless he can show that the damage, has been occasioned by a peril of the sea, for which damage he is exonerated under the terms and conditions of the bill of lading; and when goods are discharged 
and before taking delivery, if any damage is found, claim should be made in writing to the steamship agents in order to give them an opportunity of examining the goods if they so wish before removal from their eustody. This procedure in no way invalidates any claim which might be made under the terms of the insuranee poliey, for the assured, under what is known as the "Sue and Labor Clause," is in duty bound to protect the interests of underwriters.

Warehouse to Warehouse.-Goods should be eovered from the point of origin until delivered at destination, and the following clause is used in the poliey of a large Ameriean trading house:

Insurance under this policy is to attach from the moment goods are at risk of the assured at initial point of shipment, while in eourse of transportation whether waterborne or not, and covers continuonsly thereafter until the goods are delivered into store, warehouse or factory or the risk of the assured is terminated whichever first oceurs, at final point of destination, including risk of inland transportation, and whilst awaiting shipment or delivery on doeks, wharves, quays, in lighters, go-downs, warehouses, eustom house deposits and/or appraiser's stores.

To west eoast South Ameriean ports: Covering while on docks and/or in warehouses or stores of the eonsignees or in the Custom House and/or Custom House Deposits at destination but not to exceed ten (10) days in all after diseharge from lighter.

On goods destined for interior places and insured thereto hereunder, this policy covers in terms hereof until such goods are safely delivered into warehouse or store of eonsignee at such interior places.

It must be borne in mind that underwriters only cover the goods while they are in the usual course of transit and if, for any reason other than perils insured against, the transit is stopped, special insurance should be placed unti] they continue to go forward.

Special Risks. - Theft, pilferage, short delivery by vessel, leakage, breakage (unless caused by a marine peril) and 
damage due to fresh water and stains are not "perils of the sea" and underwriters are not liable unless they agree to cover such risks for an additional premium. Owing to the abnormal losses due to pilferage many companies refuse to insure such risks at any figure; consequently, unless consignees jointly bring pressure to bear on their local authorities to remedy conditions, they must be prepared to shoulder the burden themselves. It would be the best for all concerned if every underwriter would refuse to grant theft insurance, in which case consignees would have no alternative but to agitate for punishment of the guilty instead of paying an additional premium in order not to be bothered.

"Perils of the sea" do not include damage due to rain during loading or discharge or while left exposed on shore or docks. Such losses are preventable and are only due to lack of proper precaution.

Abandonment.-It should be clearly understood that merchandise is always for account of the assured until the insurance company agrees to accept abandonment, consequently, the insured should safeguard the goods just as though no insurance policy had been taken out. Some merchants believe that the moment goods are damaged they are for account of the underwriters. This is most decidedly not true.

Claims.-In the event of loss or damage by a sea peril underwriters will require the following documents: copy of Captain's protest or certificate issued by a representative of the New York Board of Marine Underwriters, National Board of Marine Underwriters, or Lloyd's Agent; eopy of bill of lading; copy of original commercial invoice, and insurance certificate, unless it is a total loss, then underwriters require all original documents.

The underwriter under a particular average adjustment on cargo is only liable for his proportion which the difference between the sound and damaged arrived values bears to the sound value, which proportion applied to the insured value gives the amount due by underwriters, plus the expenses of proving the loss. The underwriter is not 
liable for any loss on duty unless there is a speeifie insurance effected, and if such is the case he is liable for the same percentage of loss on the insured value of the duty as is shown on the merchandise.

Complaints are occasionally received that the insurance companies are seeking to avoid payment of just claims, but the writer's experience over a number of years is that the companies are always ready to pay legitimate claims and frequently pay when there is more than a reasonable doubt of their responsibility, but they certainly cannot be expected to make good for the fault of others. The tendency to claim against the insurance companies for every description of loss irrespective of the cause of damage is to be deprecated. An energetic position taken by the consignees on receipt of damaged or pilfered merchandise would, in many cases, result in a settlement by the proper parties, whereas if the claim is simply made against underwriters as a matter of course, it frequently develops that the loss was not occasioned by a peril insured against and the claim is rejected, leaving the client with no recourse except to write off the loss.

There are perhaps few subjects comnected with foreign trade about which so little is specifically known on the part of foreign shippers and manufacturers, but unless marine insurance takes its place among the other factors of shipping and banking, our foreign commerce will experience a very great leakage, and American shipowners particularly will find their competitive efforts with foreign eoncerns even more difficult. There should be coöperative measures between banking, shipping and insurance which will furnish facilities capable of supplying the needs of our national interests in the colossal struggle just before us for the world's trade. With a new power of shipping and banking service, the United States should also give its attention to obtaining a sufficient marine protection controlled in this country to make possible an enlarging confidence on the part of shippers.

There is no doubt but that Great Britain has com- 
manded the foreign trade of the world largely because she has been able to finauce it herself, carry it in her own ships, and protect both her eredit and her losses by insuring practically every dollar of her own trade with her own insurance. Before the war Germany was rapidly gathering her strength by the proper coördination of these three great elements in overseas business. Our American commerce abroad will be largely dependent upon the way upon which we are able to follow the example of our great trade competitors, adapting our policies and our methods to suit our peeuliar national products and possessions. 


\section{CHAPTER IX}

\section{CABLES-THE NERVES OF FOREIGN TRADE}

There are four great facilities of Foreign Trade-ships, banks, marine insurance, and cable and telegraph services. Lacking any one of these a nation is severely handicapped in contesting with other countries for markets and business abroad.

There are those who believe that before long a fifth and possibly a sixth great instrumentality for commerce will arrive having an important bearing upon the development and extension of both slipping and oceanic cables, namely, the wireless and the aëroplane or dirigible. As yet neither of these latter instrumentalities competes seriously with either cable communications or transportation by ships, but the great amount of scientific study, together with money expended upon wireless stations leads the exporter to hope for the arrival, at no far distant date, of a day when the air will contain both messages, men and merchandise, passing from continent to continent, annihilating spacial and geographic distances and making the world of trade one.

While it is not seriously contended that radio telegraphy will replace the telegraph and cable systems, it supplies a most valuable supplement to present cable facilities. By radio it is possible to provide direct telegraphic communciation with centers which cannot be reached by cable, either because of geographical position or due to present prohibitive cost of new eable lines. The same conditions governing the acceptance of messages apply via radio as via cable. The same codes used in one service may be used with equal facility in the other. The same registered addresses used 
for eabie communication are available for radio messages. American commerce now has at its disposal more complete facilities for international radio communication than are available to the business interests of any other country.

The radio has been found an effective substitute in place of cable communication when abnormal activity causes congested conditions in transmission of messages. Due to the war, which tied up both Atlantic and Pacific cable lines with a great mass of messages, the radio has proved its importance of caring for a large traffic of commercial messages. However, the eable at present has features of secrecy, certainty and accuracy, which present strong points in its favor.

A permanent cable was laid across the Atlantic in 1866 and from this beginning there has been a remarkable development, until at the end of 1920 there were 3052 submarine cables in operation having an aggregate length of 298,085 nautical miles. While the war stopped the development of cable laying almost entirely, there has been recently an enlargement of interest on the part of scveral nations interested in foreign trade and the facilities which the eable system offers therefor.

When it is considered that according to the Department of Commerce almost 85 per cent of our total trade with the Far East is transacted by cable and in consideration of the vast amount of business with Latin America dependent upon cable service, a knowledge of this subject becomes indispensable to those interested in foreign trade.

Of these submarine eables noted above- 532 privately owned with a length of over 262,000 miles, and 2628 govcrnment owned with a length of nearly 56,000 milesnearly 50 per cent are in the hands of British interests.

Cables radiate from England's shores to all points of the globe. Great Britain is connected with the continent of Europe by twenty-two government cables; eight to France; three to Belgium; three to Holland; six to Germany; and two to Norway. These cables, with the exception of those formerly belonging to Germany, are worked jointly by the 
British, French, Belgian, Dutch and Norwegian governments and are the chief means of communication between Great Britain, Central Europe and Norway.

An extensive and complex set of cables places Great Britain in touch with Canada and the United States. The Commercial Cable Company (U. S.) operates four transatlantic cables from Waterville, Ireland, and the Western Union Telegraph Company (U. S.) operates eight-four from Valentia, Ireland, and four from Penzance, England. The Western Union is also constructing a short cable to connect Ireland with England. These two companies are American owned.

Cable Construction.-The making of a cable, especially the ability to secure the materials entering into its construction, is a somewhat vital matter in connection with the expansion of this means of communication. To quote from an article in World's Markets written by John L. Brinda, the following facts give a gencral idea of cable construction :

The core of the eable consists of strands of copper wire covered first with several coatings of gutta-percha and then with a thick coat of wet jute, yarn or hemp for protection and insulation. Sometimes the core is inclosed in a thin layer of brass tape for special protection. The eore is finally inclosed in a cover made from galvanized iron or steel wire each separate wire covered with a mixture of gutta-percha, resin and Stockholm tar known as Chatterton's compound. Tarred tape is then used to cover the whole cable.

Although some cables have been constructed with rubber in lieu of gutta-percha, they have not proven satisfactory and guttapercha still remains the best known material for this particular use. The principal source of gutta-percha is the Malay Archipelago, and British interests have controlled-through their connection with Chinese traders and otherwise-the major portion of the world's supply. It is expected that the development of gutta-percha growing in the Philippines will sooner or later make America free of the necessity of depending on the British. The most significant fact, however, is that practically all submarine cables must be constructed in England as no other country has developed a cable manufacturing industry of any importance. 
There is only one line operated by an American company to the great markets of the Far East. This is the only American cable with one exception having landing stations, other than those on the mainland of the United States, on American territory. The cables of the All America system touch American territory at the Panama Canal Zone, at Guantanamo Bay (U. S. Naval Station) Cuba, and also Porto Rico. Although Great Britain controls 44 per cent, or 133,328 nautical miles of the world's submarine cables, the landing stations at both ends of nearly all these cables are on British soil; while the United States with 21 per cent or 63,933 nautical miles, does not control the landing stations at both ends of the cable, with the exception of that of the Commercial Cable Company to the Philippines and All America to Porto Rico and to the Canal Zone. This indicates a dominant reason for Great Britain's present cable leadership. Her ownership of countries and islands liberally scattered over the face of the world makes possible ownership and control at both ends of many of her cables, and moreover obviates to a large extent the difficulty and delay of securing landing privileges for new cable projects.

Inter-American Cables.-Inter-American Cable facilities may be divided into three groups-those which connect the U. S. with

a. Mexico, Central America and the West Indies.

b. The West Coast of South America.

c. The East Coast of South America.

The few cable connections between the West Indies and northern South America (Venezuela and the Guianas) may be included in this latter group.

For some time past All America Cables have adequately served the first two fields; the third has becn served largely by British interests until the recent extensions of the All America system to Santos and Rio de Janeiro by way of Buenos Aires and Montevideo. Messages between New York and Buenos Aires are handled with- 
out retransmission by hand, that is, by purely automatic methods, a distance of 7452 miles, in less than fifteen minutes. All America Cables contemplate making a complete circuit of the continent of South America.

Cuba.-The island is served by All America Cables from New York; by the Western Union Telegraph Company with triplicate eables between Key West and Havana; by the Commercial Cable Company from New York to Havana; by the United States \& Haiti Telegraph \& Cable Company with a single eable from New York to Capo Haitien, where it eonneets with the lines of the Compagnie Française des Cables Télegraphiques; loeally by the Cuba Submarine Telegraph Company, landings being made at points along the southern coast of Cuba. The eables of the West India and Panama Telegraph Company begin at Santiago, Cuba, and extend to Jamaica, Porto Rico, Virgin Islands, St. Kitts, Antigua, Guadeloupe, Dominiea, St. Lueia, St. Vineent, Barbados, Grenada, Trinidad and British Guiana. This Company and the Cuba Submarine Telegraph Company conneet with Cable Companies serving places north and south of Cuba.

Porto Rico.-The island is served from New York direetly by All America Cables, Ine.; from New York by the United States and Haiti Telegraph and Cable Company via Haiti and the Freneh West Indies system; by the Western Union Telegraph Company via Havana, the Cuba Submarine Telegraph Company, and the West India and Panama Telegraph Company. Messages may also be sent via All Ameriea Cables, Ine, and the U. S. Naval Wireless from Guantanamo, Cuba, as well via All America Cables and West India and Panama Telegraph Company from Santiago, Cuba.

Haili and San Domingo.-Haiti is connected with New York by the cables of United States and Haiti Telegraph \& Cable Company at Cape Haitien. It also reeeives conımunications by wireless from the eables of the All Ameriea Cables via the wireless system of the United States Naval Communications service at Guantanamo Bay, Cuba. This 
wireless service also reaehes San Domingo. The latter country is reached in addition by the Western Union Telegraph Company through connections at Havana with the Cuba Submarine Telegraph Company and the French Telegraph Company as well as by the wireless service of the Guanica Centrale from Porto Rico. San Domingo may likewise be reaehed over the lines of the United States \& Haiti Telegraph \& Cable Company from New York City.

The Virgin Islands.-All America Cables, Inc., eonnecting at Santiago, Cuba, and at Porto Rieo with the West India and Panama Telegraph Company or, at Guantanamo, Cuba, with the U. S. Naval Communieation Service, serve St. Thomas and St. Croix. These places may also be reached via the Western Union Telegraph Company through eonnections at Havana with the Cuba Submarine Telegraph Company which, in turn, eomneets at Santiago, Cuba, with the West India and Panama Telegraph Company; as well via the lines of the Halifax and Bermuda Cable Company, the Direet West India Cable Company, and the West India and Panama Telegraph Company. Guadeloupe is reached from New York via the French Cable Company, also via All Ameriea Cables, Inc., connecting with the West India and Panama Telegraph Company. Messages may also be sent via the Western Union Telegraph Company and Commercial Cable Company via Havana,-Cuba Submarine Telegraph Company-West India and Panama Telegraph Company.

List of Cable Companies Affording Cable Facilities in Latin America.-The following list gives in alphabetical order the various companies affording cable faeilities in Latin Amcrica, with special referenee to connections between the United States and Latin America:

1. All America Cables, Inc.-This system is operated jointly by the Mexican Telegraph Company and the Central and South American Telegraph Company. On Dec. 31st, 1920, All America Cables owned (not leased) over 26.000 miles of eable and land lines.

The All America Cables system, which knits together the 
United States, Mexico, Central and South America with its service of over 23,000 nautical miles of cable, was coneeived, financed, and is directed by purely American interests.

All America Cables, Inc., is operated jointly by the Mexican Telegraph Company established in 1879, and the All Ameriea Cables, Ine. (formerly called the Central and South Ameriean Telegraph Company), established in 1881. This system is said to hold the world's record for speed in transmission and accuracy in service and no money is spared in the endeavor to make it the best system in the world.

When this system first entered Buenos Aires the rate was $\$ 7.50$ per word. To-day the rate to Buenos Aires by these cables is 50 cents per word. The last reduetion to fifty ecnts was effeeted by the company on Deeember 1 , 1917, and the announcement of such a radieal reduction in the eost of cabling, at a time when the cost of everything was mounting higher and higher, was enthusiastically received by the Goveruments and the public of all the Americas.

The completion of its two new cables to Rio de Janeiro and Santos has again made it possible for this enterprising company to reduee rates, and upon the opening of its offices at those points the rate was immediately reduced from 85 cents to 65 cents per word, and a still further reduction to 54 cents per word was made on July 7, 1921. Before the advent of the Company's cables into Brazil the rate had remained stationary for years. Naturally such a progressive policy of publie service plays a large part in fostering trade relations, and a closer friendship between the American republies.

Principally for the convenience of the United States Government, and the Embassies and Legations of the Central and South American Republies, the company has established an office in Washington, D. C., thus putting the eapital of the nation in direct telegraphic touch with the nations of Latin America. 
All America Service Iines.-The All America Cables, Inc., system is composed of the following lines of communication, namely,

"Via All America" ("Via Colon" and "Via Galveston"').

From New York there are two direct duplex cables to Colon, touching at Guantanamo, Cuba. An extension has becn made to Santiago de Cuba and a direct cable has becn recently laid from Cuba to Porto Rico. A cable has been laid from Colon to Cartagena, Colombia, connecting with the main line of the system. The main cable system continues across the Isthmus of Panama by means of duplicate underground cables, miting with the submarine cables again at Panama and extending down the West Coast as far as Valparaiso.

The cables at Panama are also joined by a system of cables running north and carrying traffic for all of Central America, the company having its offices at San Juan del Sur, Nicaragua; Libertad, Salvador; and San Jose, Guatemala. Honduras is reached through Salvador, and Costa Rica through Nicaragua, over the Government telegraphs. The cables south of Panama serve the Republics of Colombia, Ecuador, Peru and Chile.

A cable also has recently been laid from Iquique to Arica, and the company has purchased the line of the Compania de Telegrafos a Bolivia, which extends from Arica by, way of Tacna to La Paz, the Capital of Bolivia, thus serving the whole Republic of Bolivia.

From Valparaiso, Chile, the lines, triplicate, extend across the Andes to the City of Buenos Aires in the Argentine; a line also connects Santiago with Valparaiso.

The company has installed cables between Buenos Aires and Montevideo, the capital of Uruguay, and the cables have been in operation since June, 1920.

Two separate cables have recently been laid connecting Montevideo with the cities of Rio de Janciro and Santos, in Brazil, thus offering a direct all American service between Brazil and the United States. 
From Galveston, Texas, there are triplicate cables to Vera Cruz and Puerto, Mexico (Coatzacoalcos). These cross the Isthmus of Tehuantepec to the port of Salina Cruz upon the Pacific Coast, and from thence connect at San Jose, Guatemala, with the cables above deseribed.

This route to Central and South America can be used to assist the main route via New York and Colon in case of congestion on that section, or should any of the cables from Panama be interrupted.

From Vera Cruz, there is a duplicate land line to the City of Mexico. Messages to and from Mexico are received from, or delivered to, connecting lines at Galveston.

Cartagena, Colombia, is less than 50 minutes from New York by All America Cables, and this company offers a direct connection with South and Central America without foreign censorship in time of war.

Mr. James A. Serymser, an American, was the founder of the All America Cables system (1879). In 1886, the staff of the home office occupying one floor at 37 Wall Street, New York, was composed of about 25 people. Today the company owns its own building at 89 Broad Street and employs over 300 at that address. The company is erecting another building adjoining its present property to accommodate its growing business.

All America Cables are the only direct means of cable communication between the Americas as well as the only American-owned company.

2. Amazon Telegraph Company (Ltd.).-This company, whose cables have been in use since 1896, owns submarine cables connecting Para and Manaos on the Amazon River, there being fourteen intermediate stations. At Para the cable joins the lines of the Western Telegraph Company.

3. Central and South American Telegraph Company, (All America Cables).

4. Commercial Cable Company of Cuba.-Cables run from New York to Cuba. 
5. Compagnie des Cables Sud-Americains.-This company operates seven eables, with a total length of 3779 nautieal miles. The principal cable extends from Dakar, Africa, to Pernambuco, Brazil. At Dakar it is eonnected with Brest, France, by a French Government cable.

6. Compagnie Française des Cables Télegraphiques.Cables of the company comect Cuba, Haiti, San Domingo, Guadeloupe, Martinique, Curacao, Dutch and French Guiana, several points in Venezuela and Salinas on the north eoast of Brazil. The company owns and operates trans-Atlantic cables connected with its Caribbean system through the United States \& Haiti Telegraph \& Cable Company.

7. Compañia Telegráfica-Telefónica de la Plata.-This company operates one cable, extending from La Plata, Argentina, to Colonia, Uruguay.

8. Cuba Submarine Telegraph Company.-Cables, totaling 1343 nautical miles, are operated by this company. Landings are made at numerous points along the coast of the island of Cuba.

9. Deutseh-Sudamerikanische Telegraphengesellschaft. - Before the war this company operated five cables, with a total length of 7386 nautical miles. A South Ameriean Cable from Emden (Germany) via the Canaries and Monrovia, Liberia (Africa), landed at Pernambueo, Brazil.

10. Direet West India Cable Company.-The cables of this company extend from Jamaica to Turks Island and from Turks Island to Bermuda.

11. Halifax and Bermuda Cable Company.-The company operates a cable from Halifax to the island of Bermuda.

12. Mexican Telegraph Company (All America Cables).

13. Pacifie and European Telegraph Company. (Ltd.). -A subsidiary company of the Western Telegraph Company. It operates land lines between Argentina and Chile.

14. River Plate Telegraph Company.-This company operates cable lines from La Plata, Argentina to Colonia, 
Uruguay, and from Colonia, Uruguay to Montevideo, Uruguay.

15. United States and Haiti Telegraph and Cable Company.-The eable facilities consist of a single line from New York to Cape Haitien, Haiti. It is operated by the Compagnie Française des Cables Télegraphiques.

16. West Coast of Ameriea Telegraph Company (Ltd.). -A subsidiary eompany of the Western Telegraph Company operating eables on the west eoast of South America. It eonneets Callao and Mollendo, Peru, with Ariea, Iquique, Antofagasta, Coquimbo, Valparaiso and Concepcion, Chile.

17. Western Telegraph Company (Ltd.).-An extensive cable system is operated by this eompany between Europe and South America, espeeially Brazil. English eables via Ascension Island and the Cape Verde Islands reach Buenos Aires; also from Lisbon via the Azores and the Cape Verde Islands to Pernambuco, Brazil. Cables extend along the Brazilian coast from Para south, touching at Maranham, Ceara, Bahia, Rio de Janeiro, Santos, Santa Catarina, Rio Grande do Sul, Montevideo, Uruguay and La Plata, Argentina. The Westem Telegraph Company recently seeured permission to lay a eable north from Brazil to the island of Barbados and planned to extend this north by way of Bermuda to Halifax.

18. Western Union Telegraph Company.-The Western Union Telegraph Company has operated eables between Florida and Cuba sinee 1875. These lines are mentioned above. In 1918 a eoneession was granted this company by the Brazilian Government to lay a cable from Brazil to one of the islands of the Greater Antilles. A number of landings were possible along the coast of Brazil -Nictheroy (across the bay from Rio de Janeiro), island of Itapariea (near Bahia), Araeajú, Parahyba, Natal, or at Para. From Para the cable was to extend to the Antilles station. Sonth from Nictheroy the cable was to extend to Maldonado, Uruguay and to Buenos Aires, Argentina. 
These concessions, however, have been given up, and the Western Union Telegraph Company plans to lay an American eable to the island of Barbados, which eable will then utilize the cable of the Western Telegraph Company from the island of Barbados to Brazil.

19. West India and Panama Telegraph Company.-The cables of this company conneet Cuba, Jamaiea, Porto Rico, Virgin Islands, St. Kitts, Antigua, Guadeloupe, Dominiea, St. Lucia, St. Vineent, Barbados, Grenada, Trinidad and British Guiana.

West Coast of South America-Additional Facilities.In addition to the service of the cables of All America Cables, Inc., the west coast of South Ameriea is served by the West Coast of America Telegraph Company, with offices in Peru, Bolivia and Chile. European messages are received over the lines of the Western Telegraph Company, with which the West Coast of Ameriea Telegraph Company is incorporated.

Extensions and Improvements.-Brazil.-The principal improvements in Brazil are in eonneetion with the extension of the cables of All America Cables' lines from Montevideo to Santos and Rio de Janeiro, Brazil, and their concession from the Brazilian Government to lay lines direct from that eountry to the United States; also the extension of the Western Union Telegraph Company via Barbados.

a. On Oetober 23, 1919, an exeeutive deeree of the President of Brazil conceded to the Central \& South American Telegraph Company (now All Ameriea Cables) without monopoly or privilege of any kind and without subvention from the Government of Brazil, the right to lay a submarine cable to eonnect the cities of Santos and Rio de Janeiro with any part of the territory of Uruguay and to carry out telegraphic communieation. A eable from Montevideo was landed at Rio de Janeiro on March 30, 1920. Permission had previously been obtained from the Government of Uruguay to lay cables from Montevideo to Buenos Aires. 
$b$. The President of Brazil has also signed a decreo granting All America Cables, Inc., the right to lay and operate a cable from Rio de Janeiro to Cuba, to run by way of the Island of Fernando de Noronha (125 miles from the coast of Brazil, northeast from Pernambuco).

c. The Compagnie des Cables Sud-Americains was recently granted permission to lay a cable from Rio de Janeiro to Montevideo, Uruguay, and from there to Buenos Aires. Permission has also been obtained by this company to take up its cable at Pernambuco, Brazil, and to land the cable at Rio de Janeiro, with a view to covering the entire cable field of the coast of Brazil.

d. The extension of the Western Union Telegraph Company for cable service between the United States and Brazil, Uruguay, and Argentina via the east coast is discussed above.

By decree of September 6, 1918, the President of Brazil declared null and void the concession granted in July, 1908, to Felten and Guillaume-Lahmayerwerke Aktiengesellschaft, of Mulheim on the Rhine, and later transferred to the Deutsch-Sudamerikanische Telegraphengesellschaft, A. G., to establish and operate, without monopoly, an ocean telegraph between a point on the coast of Brazil and the island of Teneriffe.

Chile.-The Central and South American Telegraph Company (All America Cables) purchased and assumed control and operation (February 15, 1920) of the Compania de Telegraphos a Bolivia which had maintained offices in Arica and Tacna, Chile, and in Corocoro and La Paz, Bolivia. The purchasing company has laid a cable from Arica to Iquique, where the new section of cable is connected with the company's existing cables and thus gives Arica direct communication with the United States. The Western Union Telegraph Company has obtained a concession from the Chilean Government, signed November 7, 1911, to lay a cable between Arica, Chile, and Panama. The company intends to lay from Panama a 1684-mile cable to connect with the Western Union cable 
station at Miami, Florida, and from there to Barbados where connection will be made with the eables of the Western Telcgraph Company.

Colombia.-The Central \& South American Telegraph Company (All America Cables), has recently laid a cable between Colon, Panama, and Cartagena, Colombia. The company will also extend its lines to Barranquilla, Colombia, in the near future. The concession permits the company also to touch other points on the north cuast of the Republic.

Ecuador-All America Cables have laid an additional cable-a third triplicate line-from St. Elena, Ecuador, to Chorrillos, Peru (Callao, Peru). See below under Peru.

Peru.-The Central \& South American Telegraph Company (All America Cables), have laid an additional cablo between Callao, Peru, and St. Elena, Ecuador, connecting at the latter point with the cables now running to Salina Cruz, from which city the cables run to Galveston.

Uruguay.-A Govemment resolution of September 24, 1918, contained an important provision with reference to cable concessions in Uruguay.

Article 1. This article refuses to grant the petition of the Western Telegraph Company for the extension for 30 years of its cable concession, which expired July 15, 1917.

Article 2. This provides for the presentation to the Chamber of a bill regulating cable concessions.

Article 3. This article authorizes precariously (con caracter precario) the Central and South Ameriean Telegraph Company to extend its telegraph and telephone lines from Buenos Aires to Montevideo.

West Indies.-All America Cables have laid recently a cable from Guantanamo to Porto Rico, with further extensions from Guantanamo to Santiago, Cuba. An executive deeree of the Brazilian Government under date of May 18, 1920, grants permission to the Western Telegraph Company to land at Maranham, Brazil, the cable which will be laid from Barbados to the eity of Belem (Para). 
Cable Rates.-A general idea of cable rates to Latin American countries may be gained from the following list which has been furnished by All America Cables, Inc.:

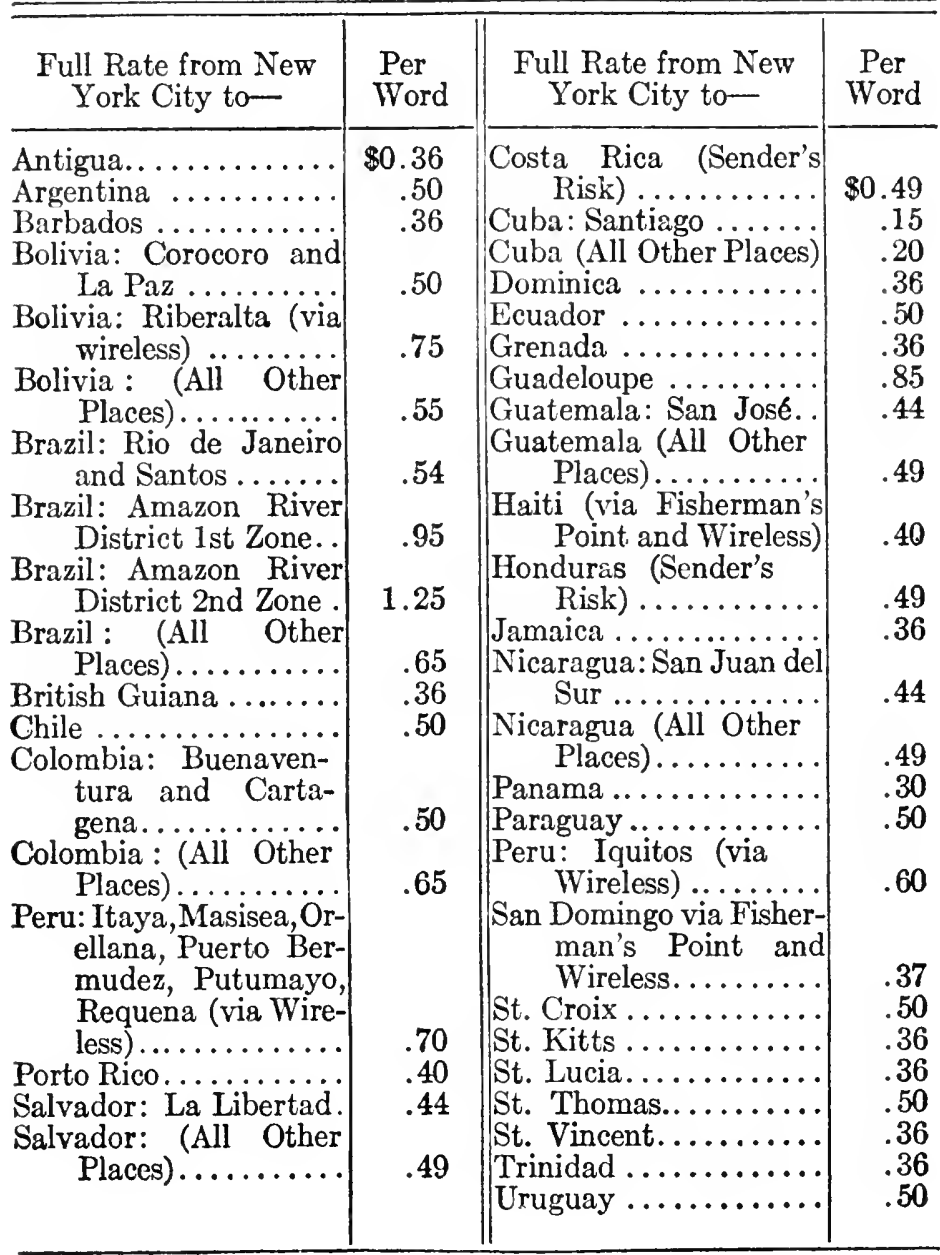

A Deferred Rate service is in operation via All America Cables to Cuba, Porto Rico, Guadeloupe, and all places in 
Central and South America, except Costa Rica, Venezuela, French and Dutch Guiana, and all wireless stations. These messages are subordinated, in the order of their receipt, to full rate traffic for a period not exceeding twenty-four (24) hours. The rate to all the above mentioned places except Cuba, is one-half the ordinary rate; to Santiago, Cuba, there is a special rate from New York City of 4 cents per word, to other places in Cuba, the rate from New York City is 8 cents per word.

Conditions. - The use of more than one language in the same message is prohibited. Messages must be written either in the language of the country of origin; of destination or in French. Code is not admissible. Figures, commercial marks, groups of letters, abbreviations, etc., will not be accepted. Numbers (except in the address) must be written in words. Deferred messages must carry one of the following prefixes:

"LCO" language of the country of origin; "LCD" language of the country of destination; "LCF", written in French. Prefixes are to be written immediately before the address and are counted and charged for as one word.

For the convenience of customers who require especially rapid cable facilities All America Cables have established an Urgent service to Argentina, Bolivia, Brazil, Chile, Cartagena, Colombia, Guayaquil, Ecuador, Peru, Uruguay, Porto Rico, Guadeloupe, Virgin Islands and British West Indies. Urgent messages take precedence over all other classes of traffic. The rate is three (3) times the ordinary rate. The indication 'URGENT' must appear as the first word in the address and is counted as one additional word.

All America Cables, Inc., announced in 1921 the inauguration of a Week-End Cable LetTer Service from its New York offices at

89 Broad Street (Main Office) . Tel. Broad 7470

7 Cortlandt Street ......... " Cortlandt 4494 
20 Spruce Street .......... Tel. Beekman 2788

136 Franklin Street ........ " Franklin 0274

234 Fifth Avenue ........... " Mad. Sq. 5056

500 Fifth Avenue ........... “ Vanderbilt 9464

(Messages Only Receivable Over Their Own Counters)

To the Following Stations of All America Cables system' in Central and South America:

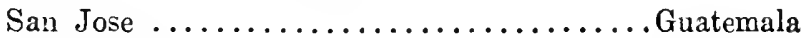

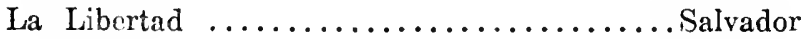

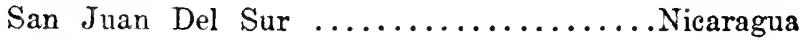

Colon

Panama $\}$

Panama

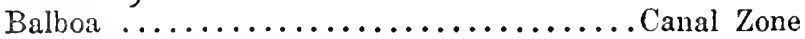

$\left.\begin{array}{l}\text { Buenaventura } \\ \text { Cartagena }\end{array}\right\} \ldots \ldots \ldots \ldots \ldots \ldots \ldots$ Colombia

Esmeraldas

Guayaquil

St. Elena

Paita

Callao

Barranco

Lima

$\mathrm{La} \mathrm{Paz}$

Corocoro $\}$

Ecuador

Tacna

Arica

Iquique

Antofagasta

Valparaiso

Santiago de Chile

$\left.\begin{array}{l}\text { Buenos Aires } \\ \text { Rosario de Santa Fe }\end{array}\right\}$

Bolivia

Montevideo

Chile

Rio de Janeiro .Peru

Santos

Argentina .Uruguay Brazil Brazil 
Messages must bear the prefix "WLT," and the prefix, address and signature will be countcd and charged for.

They must be written in plain language of the country of origin or destination. Code is not admissible. Numbers, except in addresses, must be written in words. The use of more than one language in one message is not permitted. Code addresses to their own offices may be used. To points beyond these offices they are accepted at sender's risk. They must bear the post office address and will be mailed from the nearest terminal office of this company. Messages to Colombia may only be sent to Cartagena or Buenaventura.

Week-end letters may be filed during the week but will not be forwarded before midnight Saturday, delivery at points where All America Cables have offices to be made the following Monday morning.

The following rates prevail:

From their New York City Offices to the above mentioned points (except Montevideo, Uruguay, Rio de Janeiro and Santos, Brazil) the rate is $\$ 4.50$ for 25 words or less, 15 cents for each additional word; to Montevideo, Uruguay, the above rate plus 1 cent per word Uruguayan Government tax; to Rio de Janeiro and Santos, Brazil, $\$ 5.00$ for 25 words or less, 20 cents for each additional word; plus 2 cents per word to cover the Uruguayan and Brazilian Government taxes.

The Central American Governments of Guatemala, Nicaragua and Costa Rica charge additional rates for handling this class of traffic beyond the terminal Offices of All America Cables, Inc., at San Jose, Guatemala, and San Juan del Sur, Nicaragua.

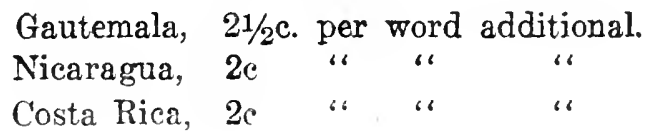


Rates from New York to points in the West Indies are approximately as follows:

Cuba:

Per word

Havana

Other places $\ldots \ldots \ldots \ldots \ldots \ldots \ldots \ldots \ldots \ldots \ldots \ldots . . . \ldots \ldots$ .20

The rates "via All America" are: Santiago and F. P.

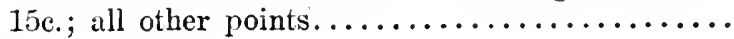

Haiti :

All America Cables-U. S. Naval Communication

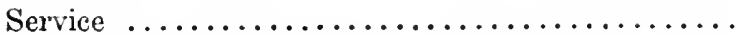

U. S. and Haiti Telegraph and Cable Co. to Cape Haitien, Mole St. Nicholas, and Port au Prince .... All other places

Dominican Republic:

All America Cables-U. S. Naval Communication

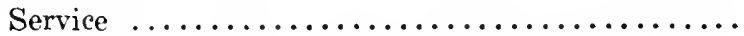

Western Union-Cuba Submarine Telegraph Co.radio of Guanica Centrale from Porto Rico ......

U. S. and Haiti Telegraph and Cable Co. .......... .40 .60 .65

French West Indies:

U. S. and Haiti Telegraph and Cable Co. ........ 1.38 Porto Rico:

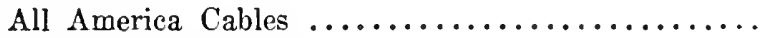

All America Cables-U. S. Naval Communication

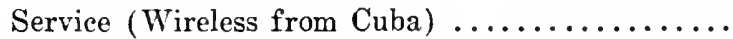

Western Union-Cuba Submarine Telegraph Co.-

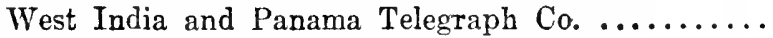
U. S. and Haiti Telegraph and Cable Co. ..........

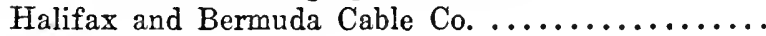

St. Thomas and St. Croix:

All America Cables-U. S. Naval Communication All American Cables and W. I. \& P. Tel. Co........ Western Union-Cuba Submarine Telegraph Co.-

West India and Panama Telegraph Co. .........

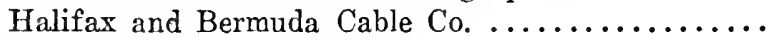

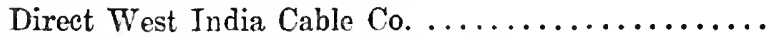
West India and Panama Telegraph Co. .......... 


\section{Guadaloupe:}

All America Cables-W. I. \& P. .............. $\quad .85$

Western Union-Cuba Submarine Telegraph Co. .... $\quad .85$

U. S. and Haiti Telegraph and Cable Co. ........ $\quad .85$

Halifax and Bermuda Cable Co. ............. $\quad .85$

Direct West India Cable Co. ............... $\quad .85$

West India and Panama Telegraph Co. ........ $\quad .85$

The Art of Using Cables.-The foreign merchant and particularly the men who are responsible for telegraphic and cable intercommunication should not only be familiar with cable systcms, but also should be versed in the practical art of using them in the most attractive and economical manner.

In our export houses where there is a regular coding and cable department it becomes increasingly important for the people responsible for sending cables to understand something of the business. A cable man who can also combine with his knowledge of cables a merchandising and shipping knowledge becomes of special value to his company. At least there is the necessity of a close coöperation between the merchandise man and the cable clerk in order to avoid costly errors and to bring about the most economical communication.

In order to follow a cable in its course from the man who writes it to its destination we are giving herewith some practical hints from an experienced cable operator :

In writing a message which is to be sent by cable, the first thing to be borne in mind is, of course, whether the subject is really worth the expense of a cable or whether a letter could not be written just as well. In deciding this, the importance and urgency of the matter is the first consideration, then the comparative length of time required for a letter or cable to reach the given destination, the cable rate to that point, the number of code words the message will require, ete. In the majority of cases there is no difficulty in deciding whether a 
cable is advisable or not, but there are cases in which cables are sent where a letter would do as well, and there are others in which no cable is sent where one might be worth while. All these things have to be eonsidered and, of course, no one but the man doing the business ean make the decision.

As stated, he should write his message as far as possible in phrases most commonly used in business, and which are most likely to be found in the code. The writing of eables can be made an art in itself provided one knows something about the codes, and provided also, which is most essential, that each message be eomposed not alone from the standpoint of the man writing it and who knows the transaction and what is in his own mind, but taking the position as far as possible of the man at the other end who does not know so much about it. After every message is drafted the writer should endeavor to put himself in the place of the man at the other end and read the message over to see whether it will convey to him all that he should know.

There are other little points which ean be taken advantage of if they are known, such as the fact that it is in most cases cheaper to refer to only one word than to two or more. Referenees should be written out elearly on the eable memorandum, to enable the eable department to eheck the correctness of them. Whenever you write a letter to which you want a reply by cable, it is often advantageous to secure a special code word or words from the eable department for inclusion in your letter, by means of which your correspondent can cable you in one or two half words that might otherwise take several full words.

There is the subject of domestic telegrams, ineluding messages to Cuba, to which due attention is not always given: telegrams are frequently verbose; advantages of the night and day letter services should be borne in mind, and the eorrect way of writing out numbers in a telegram. As far as possible send your eables to the eable department early in the day; do not hold them all until closing time, as this means that the cable department will have eomparatively little to do during the day and be swamped at night.

Notation should be made on the message to indicate to the cable department just how urgent it is, and whether it should be sent "Immediately," "Some time today," or "In next message." 
If the message is immediate it should be so marked so that it will be given preference by the cable department and not held to take its turn; if it is not so urgent it can be coded when its turn comes. Very often it ean be combined with another message for the same addressee, which saves two words, as the cable company charges the same rate for each word in the cable address as for words in the body of the message. For messages which are exceptionally urgent, there exists what is known as an "Urgent Rate" service to most destinations, for which the rate is three times the ordinary rate, and messages sent at this rate are given preference by the cable companies over all others. Some cable companies, however, maintain no "urgent" rate.

Another detail which is sometimes overlooked is that of indicating on the message where the cost of it should be charged. Every cable costs money, and it is important from an accounting standpoint to know to what accounts the costs of the various messages should be charged so that the cable company's bills can be properly allocated when they come in. This should never be omitted.

The message when written must go to the cable departmentwhich is a detail that might be considered not worth mentioning, but it is well to remember that it is quite possible for it to get lost or seriously delayed between departments, and steps should always be taken to assure that it reaches the cable department promptly. The best method is to write cable memoranda in duplicate and have the cable department initial and return the copy.

Having reached the cable department it is immediately numbered and a record made of it; it is coded by one of the cable clerks, his coding being examined by the one in charge to determine whether it has been economically and accurately done; the code message is written out on cable blanks and the typewritten copies of the message as coded are made, with the words properly numbered. The coded cable is retranslated by a cable checker as if it were an incoming message and his translation is compared with the original; the cable is then given to the telegraph operator for transmission over the pony wire to the cable office, where it is sent along on its journey.

In due course the message arrives at the other end, is trans- 
lated and checked by the cable department there in much the same manner as our incoming messages here, and the copies distributed to those who should get them.

Ownership of Cables.-It is of interest to note the ownership of the world's cable systems:

Submarine Cables of the World Privately Owned

\begin{tabular}{|c|c|c|}
\hline Companies & $\begin{array}{c}\text { Number } \\
\text { of } \\
\text { Cables }\end{array}$ & $\begin{array}{l}\text { Length, } \\
\text { Nautical } \\
\text { Miles }\end{array}$ \\
\hline African Direct Telegraph Co. (British) & 9 & 3,056 \\
\hline Amazon Telegraph Co. & 20 & 1,388 \\
\hline Canadian Pacific R. R. Co. & 11 & 103 \\
\hline $\begin{array}{l}\text { Central and South American Telegraph Co. } \\
(\text { All Amcr.) (U. S.) } \ldots \ldots \ldots \ldots \ldots \ldots \ldots \ldots \ldots\end{array}$ & 25 & \\
\hline Commercial Cable Co. (U. S.).... & 15 & 17,274 \\
\hline Commercial Cable Co. of Cuba (U. S.) & 1 & 1,285 \\
\hline Commercial Pacific Cable Co. (U. S.). . & 6 & 10,010 \\
\hline 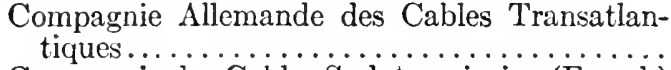 & 5 & 9,556 \\
\hline Compagnie des Cables Sud-Americains (French) & 7 & 3,779 \\
\hline $\begin{array}{l}\text { Compagnie Française des Cables Télegraphiques } \\
\text { (French) } \ldots \ldots \ldots \ldots \ldots \ldots \ldots \ldots \ldots \ldots \ldots \ldots\end{array}$ & 25 & 11,657 \\
\hline Compania Telegrafico-Telefonica de la Plata... & 1 & 28 \\
\hline Cuba Submarine Telegraph Co. (British)...... & 11 & 1,338 \\
\hline $\begin{array}{l}\text { Deutsch-Atlantische Telegraphenges (German). } \\
\text { Taken over by Great Britain............ }\end{array}$ & 5 & 9,661 \\
\hline $\begin{array}{l}\text { Deutsch-Niederlandische }{ }^{2} \text { Telegraphengesell- } \\
\text { schaft }(\text { German }) . . \ldots \ldots \ldots \ldots \ldots \ldots \ldots \ldots\end{array}$ & 3 & 3,416 \\
\hline 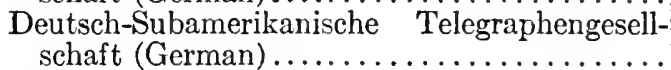 & 5 & 7,386 \\
\hline Direct Spanish Telegraph Co. & 4 & 711 \\
\hline Direct West India Cable Co. (British) & $\overline{2}$ & 1,263 \\
\hline $\begin{array}{l}\text { Eastern and South African Telegraph Co. } \\
\text { (British) } \ldots \ldots \ldots \ldots \ldots \ldots \ldots \ldots \ldots \ldots \ldots\end{array}$ & 16 & 10,536 \\
\hline 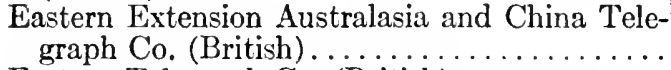 & 33 & 26,475 \\
\hline Eastern Telegraph Co. (British). & 140 & 46,615 \\
\hline Europe and Azores Telegraph Co. (British). & 2 & 1,060 \\
\hline Grande Compagnie des Télegraphs du Nord. & 29 & 9,331 \\
\hline Great Northern Telegraph Co. (Danish). & 30 & 8,411 \\
\hline
\end{tabular}


Submarine Cables of the World Privately Owned-Continued

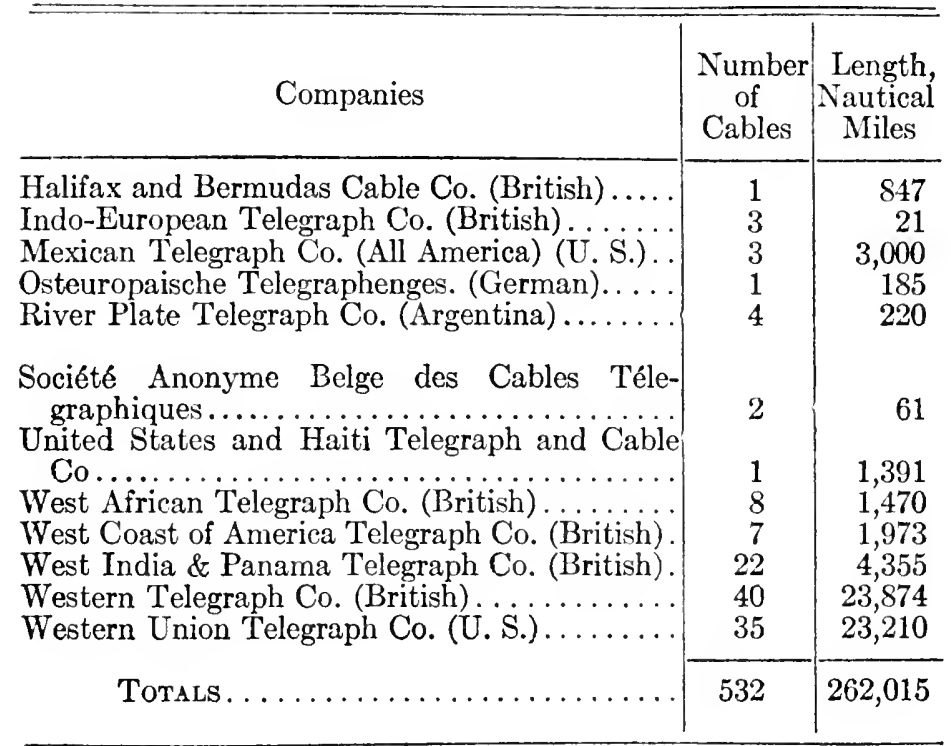

Cables Owned by Nations

\begin{tabular}{|c|c|c|}
\hline Countries & $\begin{array}{c}\text { Number } \\
\text { of } \\
\text { Cables }\end{array}$ & $\begin{array}{l}\text { Nautical } \\
\text { Miles }\end{array}$ \\
\hline Argentine Republic. & 22 & 84 \\
\hline 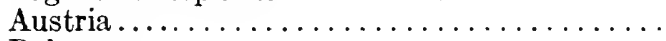 & 87 & 713 \\
\hline Bahamas. & 1 & 211 \\
\hline Belgium.... & 4 & 100 \\
\hline Brazil.. & 33 & 10 \\
\hline British Guiana. & 8 & 23 \\
\hline British India... & 13 & 2,325 \\
\hline Bulgaria....... . & 1 & \\
\hline Canada. . & 76 & 376 \\
\hline Ceylon and India (joint) & 2 & 66 \\
\hline China....... & 3 & 1,003 \\
\hline Denmark. & 153 & 451 \\
\hline France and Algeria. . & 59 & 3,300 \\
\hline France......... & 18 & 9,002 \\
\hline
\end{tabular}


Cables Owned by Nations-Continued

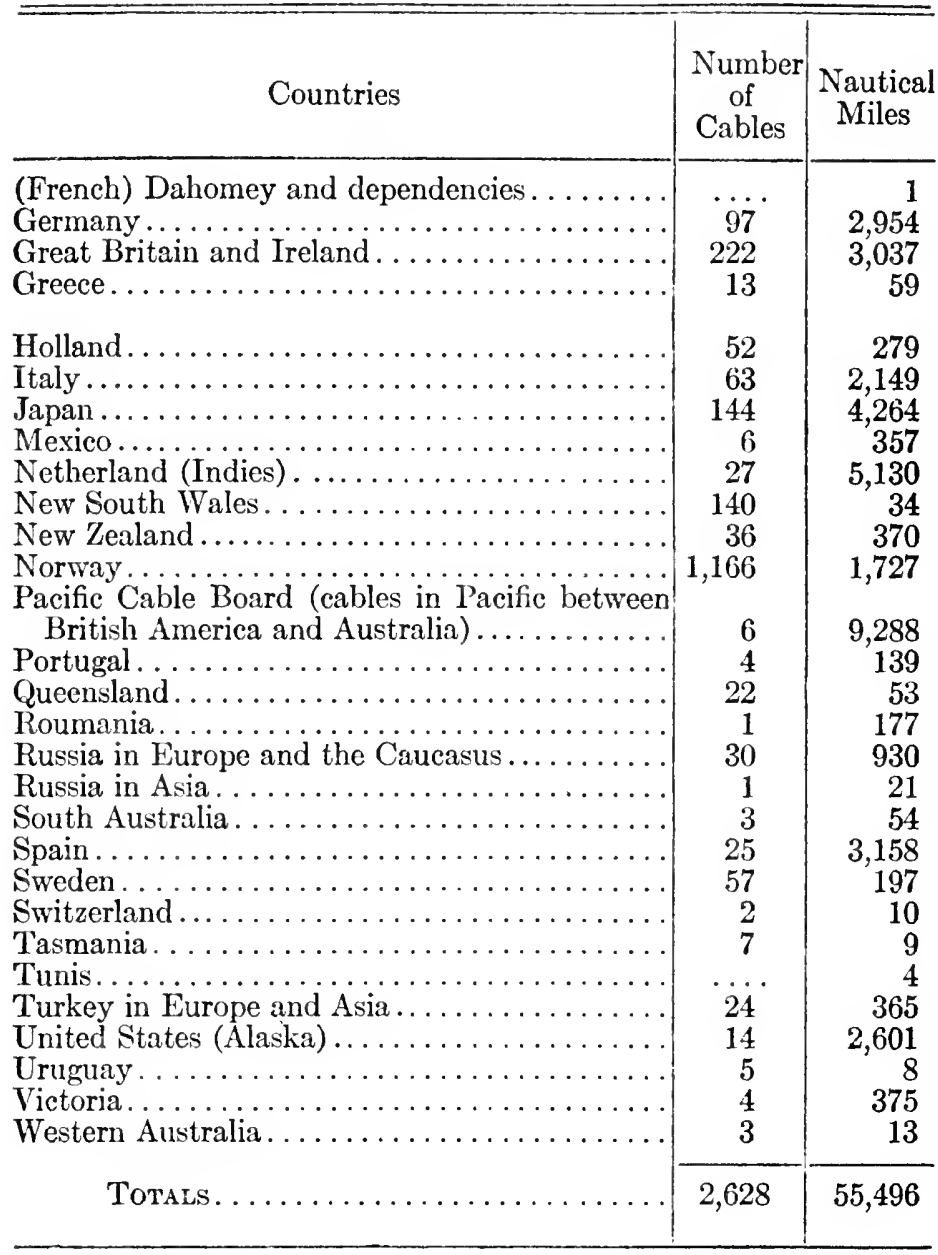




\section{CHAPTER X}

\section{FINANCING FOREIGN TRADE}

According to conservative figures there have been invested in the United States since 1914 in new productive enterprises and machinery more than $\$ 6,000,000,000$. Add this to the business and trade operations in existence before the war and one can readily see the necessity of developing overseas commerce to absorb the surplus in production in this country.

American foreign trade, which doubled between 1903 and 1913, has made of late such strides that manufacturers and business men generally are seeking as never before to know the means by which such trade may be opened and prosecuted. The modus operandi of the financial and commercial operations are among the important things which the manufacturer desiring to engage in foreign trade must thoroughly understand. It is not enough to leave this matter to the export agent or the bank, if the merchant or the maker of goods for export is ultimately to succeed in overseas trade. He must needs give personal attention to the understanding of the methods of financing his shipments.

The comparatively recent establishment of a chain of American banks in foreign countries has made possible a new and indispensable advantage to our foreign commerce. There has been no weaker spot in our international trade armor than the lack of our own banks abroad, through which our trade operations may be carried on, thus safeguarding the knowledge concerning our foreign activities and enabling our home traders to facilitate readily commercial operations overseas. 
Among the services rendered by such banks there has been outlined certain privileges given by one of our banking establishments, the National City Bank of New York, which has established in the past five years, 85 branches throughout the world.

The following facilities offered by this bank give a general idea of the agencies concerning which the foreign exporter should be more or less familiar:

\section{Services Rendered by Branch Banks}

The facilities which our foreign branch banks enable us to offer our clients may be epitomized as follows:

1. The collection of drafts drawn upon foreign houses.

2. The protection of the interests of American merchants through the control of "To Order" shipments until payment or acceptance by foreign purchaser of the corresponding draft.

3. The protest of drafts where drawer so instruets.

4. The securing of legal services in foreign countries through our own foreign attorneys.

5. The creation of foreign markets for dollar exchange.

6. The collection of credit data on foreign houses, and the continued study of foreign market and eredit eonditions, reports on which are constantly forwarded to New York for the information of our American elients.

7. The forwarding, to our branch banks, of eredit information upon firms represented by American travelers, thus enabling these representatives to refer foreign merchants to our branches for credit information concerning their principals.

8. The collection of trade data covering the possibilities in foreign countries of American manufactures and products of every description.

9. The study of foreign market conditions covering commodities produced in the foreign country for export.

10. Upon request, letters of introduction and letters of credit are issued from our New York office to our foreign branch correspondent banks placing at the disposal of our American clients or their representatives who may be traveling the varied facilities of our foreign offices and connections. 
11. Branch banks through coming directly into contact with the trade and financial problems arising in both the export and import field assist materially in their solution through the publicity of the results of special study of such matters.

12. The assistance rendered in the development of American foreign commerce, both import and export, through the direct banking facilities afforded at home and abroad and in general tlirough the bringing about of a far better commereial understanding between this country and the countries in which our branch banks are functioning.

Financing Foreign Shipments.-There seems to have been a feeling in the minds of many would-be American foreign traders who have had little touch with foreign business, that it is rarely safe for them to allow merchandise to leave the country unless it is paid for in advance or before shipment. This condition of mind is duc, of course, to ignorance as to the business integrity of foreign buyers.

Already the agencies for securing reliable eredit information are sufficiently extensive to make financial operations in conneetion with export and import trade almost as secure as they are in our own country. The finaneing of export shipments, however, should not be confused with credit. The two subjects are naturally closely related but although certain American banks have extensive lists of credit information concerning foreign firms, nevertheless, they are not supposed to guarantee payment of invoices for goods shipped to a foreign country. The bank's business is to furnish funds to carry the merehandise from seller to buyer by discounting the draft. Credit information is given by banks when possible, but the final responsibility of trusting the customer rests with the seller or the exporter. The bank simply follows the instruction of its client, the preparation of documents including bills of lading, insurance certificate, invoices, consular invoice, certificate of origin, weight note or packing aceount, etc., are all routine matters and involve the work of the shipper. The bank, however, must see to it 
that it has a clear title and that goods are properly insured.

The first essential in the finaneing of foreign shipments is for the seller to have a very definite understanding with the buyer about the method of payment. This is extremely important and it is because of the lack of sueh understandings that many of the mistakes and misunderstandings in connection with overseas trade oceur. No doubt should be allowed to exist in the minds of either party as to whether the method of payment is to be in eash, time, or open account. The wishes of the buyer should be clearly known as to what the price shall include, that is, F.O.B. cars (at factory), F.A.S. steamer, or F.O.B. steamer (at port of shipment), C. \& F. (cost and freight to port of destination), and C.I.F. (eost, insurance and freight to port or place of destination). There is a very prevalent idea that prices on a C. \& F. or C.I.F. basis presume an extension of credit, but that is not so, and payment may be required in advanee of shipment, quite as well when selling C.I.F. as on sales made F.O.B. factory, or, on the other hand, drafts at long time may be used to settle F.O.B. sales. It does not follow that because all of the above methods or terms may be used that they necessarily will be, but it is highly important that the representative of the seller should be thoroughly familiar with their neaning and able to apply them in a practical way, so as to translate one into another. This latter is particularly necessary, for without it it is impossible to make a comparison of the prices offered by eompetitors unless they happen to be identieal in terms. Jt must be kept in mind by the candidates for salesmanship honors abroad that it not infrequently happens that a merchant in some sinall city will be better informed both about his own business as well as general business, than the man sent from this country to solicit his trade and first impressions should not be too strongly relied upon. The salesman who ean whistle only one tune very quickly exhausts his repertorie and stands a poor chance either of making 
a sale or learning what his competitors are offering making them more successful than himself, and no time nced be considered wasted that is spent in making price calculations that enable a salesman to approach his customer from the easiest angle.

Credit vs. Cash Policy.-The European example of giving extensive credits, sometimes in Latin Anerica as long as nime montls or a year, gathering along the way interest charges and also certain commissions, has not been followed to a very large extent by Americau manufacturers or exporters. Nevertheless the extension of credit to customers overseas is absolutely essential in certain cases in order to meet the seasonal requirements of agrieultural enterprises, as well as to accommodate the buyers whose business is often affected by the fluctuation of exchange. Moreover in some cases the foreign merchant requires time for a partial turnover of his goods if be is going to remain in business; therefore many foreign buyers look at the credit arrangements to be obtained from our exporters and manufacturers almost as closely as they do the price and the quality of the goods, and an advantageous credit arrangement often determines the decision of the foreign buyer.

In a report from the American Consular Office at Malaga, Spain, it was shown that of 630 letters received by this office from American exporters seeking a field of trade in this district, only one contained a request for information as to credit usages; the other letters all asked for full details as to opening negotiations for new goods, competition to be met, market demands, results to be expected from advertisements or local agencies, customs regulations and tariffs, but leaving entirely out of their calculation the subject of credits, seeming to take it for granted that the local trade would adapt itself to American usage in this matter. In fact out of 222 catalogues received from American manufacturers by this Consular office in Spain a demand for cash payments was shown by 85 per cent while the best terms offered by the remaining 15 per cent 
were delivery of the shipping documents against an acceptance of drafts at 30 to 90 days' sight.

The suspicion which Americans have had of credit business abroad has been due quite largely to the lack of financing agencies such as bank acceptances and the open discount market which have prevailed in Europe. There has been also until very recent years considerable difficulty in securing credit information. Latin American business houses do not so easily or willingly give upon request an account of their assets and liabilities as do houses in the United States. Of course the best way to get credit information is by personal contact, sending a responsible agent or taking the trip oneself for the sake of acquaintanceship. Any South American business man who comes to know you will be quite willing to give you credit information required relative to his business. Furthermore, the leading banks of the country, as well as chambers of commerce, such bodies as the American Chamber of Commerce in Buenos Aires, Rio de Janeiro, Shanghai and other foreign cities will furnish credit information upon application.

Just here it may be well to add that very long credits are considered increasingly to be bad economics. During a visit to Chile some years ago one of the most influential Chilean business men told me he believed too long credits to be a misfortune to his people, or to any nation, since the goods in the end cost much more, and furthermore the temptation is thrown in the customers' path to utilize the cash which he should be saving to pay for his goods in speculation or for immediate needs. It is doubtful whether such long credits as were known before the war will again be general. The important essentials for successful trade will always be quality, good service, low prices and methods of financing satisfactory to both parties involved.

The following remarks relative to the subject of credit by Mr. C. E. Hammond of the Foreign Credit Department of a large foreign merchandising firm are suggestive and useful : 
In order for a merchant to be in a position to offer the best possible terms, he must know his prospective client as well, if not better, than his competitors. In determining a firm's claim on eredit facilities the three big ' $\mathrm{C}$ 's' play a large partCharacter, Capability, and Capital. Character needs no explanation, for business character is just as important as personal moral character. CAPABILITY indicates in what manner a customer will be able to dispose of your merchandise at a profit and the skill exhibited in disposing of same in the shortest possible time, so that he will be able to meet your draft out of the proceeds of his sales. CAPITAL regulates the quantities which the eustomer can purchase. In analyzing a firm's balance sheet should you notice, in comparing it with previous balances a consistent increase in capital, you may be sure that the eapability displayed by that firm entitles it to consideration for a liberal line of credit.

In soliciting business, the best practice calls for investigation of client before taking his order-the reason lies in the economy of effort and betterment of service. Wasted efforts on the part of your salesmen result if the order is not shipped after being solicited, on account of credit. It is far better to confine sales to desirable prospective customers, than to solicit indiscriminately.

A salesman will find it to his advantage to investigate a prospective eustomer prior to soliciting the business so that his report will be in the hands of the Credit Department before his order is submitted for approval, thereby eliminating delay in execution, which would otherwise result if the same had to be made the subject of eredit investigation. If this plan is not followed it becomes necessary for the Credit Department to make investigation through local quarters. There are various sources for this information. A large number of New York banks have either branches or correspondents in foreign countries and consequently their credit information files are quite complete. This information usually gives a firm's declared capital, net worth, manner in which they are in the habit of meeting their obligations, whether or not they make claims, etc. Should the customer be a elient of the bank's branch they will be able to tell if accommodations are solicited and how such accommodations are taken eare of.

The declared capital in some countries cannot be used as a basis for eredit extension, as firms are taxed by their Governments on declared capital, consequently in most eases the declared 
capital is a good deal less than the amount with which they are operating.

Then there are the trade investigations. This will give you the experience of other merchants, providing of course, they will be frank in expressing themselves. Reciprocity among exporters and bankers is becoming more general in the line of exchanging business experiences on foreign customers. The free exchange of opinions between merchants is of vital importance. This fact has been very vividly brought out in a recent experience by U. S. merchants in dealing with Cuban clients. Just prior to the drop in the dry-goods market they were selling freely to Cuban buyers with the understanding that these customers were confining their purchases to two or three suppliers. When the drop came it was discovered that these same buyers wero indebted in some cases to over thirty U. S. firms who had all been extending liberal credit under the impression that they were supplying the customers exclusively. This condition could havo been avoided if a free exchange of opinions had been solicited before accepting any business. The National Association of Credit Men is endeavoring to eliminate a repetition of just such an occasion by making inquiry of exporting concerns on any particular firm inquired about by one of their subscribers. To all firms replying they send a complete summary of the opinions submitted.

There are also the Commercial Agencies such as Dun and Bradstreet. These reports are only available to subseribers of their service. The minimum number of reports which ean be obtained is twenty-five, covering a period for one year, for which they charge $\$ 60.00$ with an additional charge of $\$ 2.50$ each for any report in exeess of the above number, excepting of course if the subscription is for a larger number, which is charged for on a graduated scale.

Commodity plays an important part in granting eredit. If the merchandise in which you are dealing is in any way speculative, or if there is likely to be a drop in price, it is advisable to look very carefully into the reputation of your client. If he should be an unscrupulous man he would have no hesitancy in refusing shipment on arrival or canceling order after you had already compromised yourself to buy. In that case there is very little redress for the exporter, for lawsuits are very longdrawn-out affairs in foreign countries and the chances are very slight that you will be able to recover damages. 
There is another commodity hazard. Some merehandise is so perishable that, if shipped at a certain season of the year, it will deteriorate and be absolutely worthless when it reaches its destination. I am speaking now covering shipments to South America. The long voyage and climatic conditions through which it passes on its trip, play sad havoc with some commodities. These many phases must be very carefully studied by the Credit Department.

Relative to the steps taken when an order eomes from a country like South America, the following can be stated as a method of quite general procedure:

Usually we receive some kind of inquiry from our own agency or branch house prior to receiving the order. We then investigate the name through local banks to endeavor to ascertain their opinion of this particular client, as well as searching our own files for previous information. On cable orders, however, we must depend to a great extent on our agency's knowledge of the client, as we cannot hold up these orders. It is the custom to confirm cable orders the same day they are received, and if we are unable to identify the client locally we confirm the order subject to a satisfactory credit report.

Generally speaking, while American firms are opposed to long credits, the conviction is growing that good service rendered to clients will tend to overcome the objection of the client demanding long terms of credit.

There are usually three ways of payment for goods sent overseas :

1.-There is the open credit plan which is used quite generally by commission houses and by established foreign trade firms having their own branches in different parts of the world and thereby the ability to get first hand information concerning the financial and trustworthy standing of possible clients. This credit is granted to a customer on the books of the seller and gives him the privilege of ordering up to a certain amount with credit from one to four months, or whatever the ease may be.

2.-Payment by draft against the importer, at sight or 30-60 days or more, is another method of payment. 
3.-Then there is eash payment either at point of shipment or at destination, the eustomer placing funds in a bank at one point or the other to meet such cash payments when the goods are ready for shipment.

4.-There is also the Aceeptanee Credit, the drafts under which, when drawn by the beneficiary up to six months' sight, exclusive of days of grace, are "aceepted" by a bank, for payment at maturity. Such drafts, when aecepted by a member bank of the Federal Reserve system are eligible for discount in the open market or for rediscount with a Federal Reserve Bank at best rates, in aecordance with the Federal Reserve Board's rulings on sueh aceeptances. To establish eredits of this nature it is neeessary that the purchaser in a foreign country deposit with his local bank the equivalent of the required amount as collateral, or arrange with the bank accommodation to provide for the ansount involved.

The operation of these Commercial Credits, when made available in this country, is as follows:

The branch bank or correspondent in the foreign country through which the credit has been created, informs the home bank of the opening of credit, and it in turn informs the beneficiary that the eredit has been established in his favor, and also the amount and the conditions under which the bank shall make payments or aecept drafts drawn thereunder.

Many large purchases are effected through this medium, the credits being arranged not only by South American firms in favor of firms in the United States, but also by American firms in favor of South American and European houses.

Where the foreign merehant does not open a Commercial Credit to cover his merchandise purchases in this country, payment is usually effected through the medium of a draft which is forwarded for collection, either with or without the shipping and other documents, to a foreign branch or correspondent bank.

Although there are many terms more or less technical 
with which the foreign merchant soon becomes familiar, the foregoing methods of financing are more or less basic in principle. In order to illustrate a complete transaction from the opening of the credit to the final payment, we present an illustration offered by the National City Bank of New York which will give a somewhat practical idea step by step of foreign trade financing:

A merchant in the Argentine, let us say, has ordered a quantity of machinery from a Chicago house. As the Chicago house is not familiar with the credit standing of the Buenos Aires firm. let us suppose that the information in our eredit files is not, in this instance, of a nature to warrant the extension of time. The Chicago house thereupon cables the Argentine merchant that the order will be entered if a confirmed commercial eredit is opened in their favor through The National City Bank of New York.

A confirmed credit is required in this instance, as the machinery may be of special manufacture, and the Chicago house, before commencing work upon it, wishes to be secured against a possible revocation of the order when perhaps the machinery is half completed.

The Buenos Aires merchant, acquiescing in the demand of the Chicago house, arranges with the Buenos Aires branch of The National City Bank of New York for the opening of, say a $\$ 20,000$ confirmed credit, to be availed of through the main office of the bank in New York.

The Chicago house is made the beneficiary under this credit, which is practically an order on the New York office of the bank, either by cable or letter, to pay to the Chicago house that amount stipulated, generally upon delivery to the bank of a full set of shipping documents covering the shipment. If the eredit were an 'acceptance credit,' the New York office of the bank would 'accept' the draft of the Chicago house for, say thirty or sixty or ninety days, as may have been agreed upon.

Upon receipt at New York of either the cable or letter opening the eredit, the bank at New York immediately notifies the beneficiary (the Chicago house in this instance), that such credit has been opened and the conditions upon which payments thereunder will be made. It will be noted upon reference to the definition of a 'confirmed credit' that this kind of eredit can be revoked only with the consent of the four parties concerned, viz.: the 
Buenos Aires merchant, the Buenos Aires branch of the National City Bank of New York, the New York office of The National City Bank of New York, and the beneficiary at Chicago.

The machinery having been completed, the Chicago house consigns it on railroad bill of lading to its New York agent, or, in the absence of a New York agent, then to some reputable forwarding house at New York, the shipping port, with instructions to secure the ocean bills of lading, the Consular invoice, insurance certificates, and other necessary documents. These documents are thereupon presented to the bank, and if they are in order and meet the requirements of the eredit, payment will be made by the bank, usually through the medium of a bank check to the order of the beneficiary. If, however, the beneficiary is a depositor of the bank, it is probable that the amount will simply be credited to his account.

The bills of lading are generally made out 'To order' and are endorsed in blank by the shipper, after which they are forwarded to our Buenos Aires branch. 'To Order' bills of lading, however, are not permissible to Venezuela and Colombia, to which countries it is necessary to consign documents and merchandise direct to consignee. More eare is therefore neeessary in looking into the credit standing of consignees in those countries.

It will be noted in the transaction we are following that as the bills of lading have been made out 'To Order' and endorsed in blank, the bank, having possession of the documents, practically controls the shipment, and the Buenos Aires branch will surrender these evidences of title, which we shall assume have gone along on the same steamer carrying the shipment, only upon compliance by the purchaser in the Argentine with whaterer conditions were agreed upon in the undertaking creating the eredit.

These conditions may take various forms. If the eredit standing of the Argentine merchant is beyond question, it is possible that he has established with our branch a line of eredit to cover his eommercial eredit operations, in which event the documents may be surrendered to him without collateral security being placed with our branch bank.

Should security be deemed advisable, this may take various forms, such as depositing with the branch acceptable securities (bonds or stocks) until liquidation of the obligation, or perhaps the depositing of a note bearing the endorsement of a responsible individual or firm. It may have been agreed that such surrender is to be made upon acceptance by the Argentine merchant of a 
draft to be drawn upon him for an agreed tenor by our Buenos Aires branch. It may also take the form of a trust receipt to be delivered to the branch by the Argentine merchant, under which, title to the merchandise remains in the name of the bank, the proceeds or part thereof, of partial sales to be turned over by the merchant to the branch until complete liquidation of the transaction. There is usually more form than substance to a trust receipt, however, as once the merchandise has been placed in the warehouse of the purchaser it is not an easy matter, in fact it is practically impossible in most instances, to have it so marked as to keep it safely segregated from other merchandise for identification in the event of default or other impediment arising.

It is possible that the conditions of the eredit, owing to the financial and eredit standing of the Argentine merchant, may be broad enough to permit the documents' being forwarded dircet to the Argentine merchant by the shipper in the States, in which case such documents should be made out to lis order direct.

In the case of an 'acceptance eredit,' the draft drawn upon the bank by the beneficiary (in this instance the merchant in Chicago) will be accejted by the main office of the bank of New York, under the Federal Reserve Act which grants to national banks the privilege of accepting bills of exchange growing out of transactions involving the importation and exportation of goods. This acceptance usually takes the form of a stamp across the face of the draft, with the word 'accepted' and the date, with the signature of a duly authorized officer of the accepting bank, and will thereupon be detached from the other documents for return to the Chicago firm, to be discounted by them inmediately, if they prefer, or to be held by them until the maturity date thereof.

In the case of the 'acceptance credit,' the conditions at Buenos Aires under which the eredit was originally opened quite likely specify that payment is to be made some days prior to the actual maturity date of acceptance at New York, through tho medium of a draft to be drawn by our Buenos Aires branch upon the Argentine importer. This draft is given an earlier maturity date than the Chicago draft, in order to enable the Buenos Aires branch of the bank to cable the funds to New York in time for the New York office to meet its acceptance of the draft of the Chicago house.

One of the points of difference between the ordinary confirmed documentary credit and the 'acceptance credit' is that under the 
former it is not always necessary for the American shipper to draw drafts, the conditions of the credit usually instructing the bank to pay cash against receipt of documents, the bank taking simply the receipt of the shipper for payments made thereunder. This receipt may consist simply of the endorsement of the beneficiary on the bank's check for the amount involved. Under the 'acceptance eredit,' however, the instructions from the bank through which the credit was originally opened to the bank through which it is to be made available, would be to 'aceept' the draft of the American shipper, under certain specified conditions, such acceptance by the bank protecting the maker of the draft, in the case of the Argentine merchant, from becoming insolvent before maturity date. The recourse of the New York bank under such a contingency would be to the foreign bank which originally opened the credit and upon the instructions of which acceptance was made.

The illustration here given covers an export transaction; the operation for an import transaction is the same with simply a reversal of the various incidental steps. 


\section{CHAPTER XI}

\section{IMPORTANCE AND ADVANTAGES OF KNOWING COMMERCIAL LANGUAGES}

Interest speaks all sorts of tongues.-Francis, Duc de la Rochefoucauld.

More than at any other time in the history of our foreign trade has the learning of a foreign language for commercial purposes become an absolute necessity. More and more American exporters are realizing they must create markets and then hold them in competition with all the world rather than simply send goods to markets that have been already developed. During the war there were some foreign markets where American goods were well known, where the buyers often had English-speaking representatives to accommodate the exporter. In the Far East, for example, it is possible to conduct nearly all our foreign transactions in English. This is due to the craze to learn English which is everywhere apparent among Asiaties.

In certain lectures to students in India the presiding officer makes the statement beforehand that the lecturer will speak entirely in English and that those students who do not understand English will be free to retire at any time. The result is that every student holds firmly to his seat and tries to look interested and intelligent, regardless of whether or not he understands a word of the lecture. Otherwise, the students would be quite inclined to go out and come in at their will during the lecture, according to their eustom in some parts of India.

A Chinese student in Peking advertised in a daily paper, "I teach English as far as thc letter G." 
A student who sat beside me in a Tokyo tram car was very desirous of impressing me with the faet that he was familiar with English. He held Burke's Reflections of the French Revolution close to his face, glancing frequently at me to discover if I noticed him and was sufficiently impressed. In looking more closely I noticed that he was reading his English book "bottom side up."

While this eager desire for a knowledge of English prevails in the Orient, it is not so prevalent in other foreign markets. It is true that, during the period of the war, not only such countries as China and Japan had Englishspeaking representatives for the convenience of the exporter, but such was the case even in Latin America where a digression from Spanish and Portuguesc is seldom found. However, this was at a time when competition was not strong and when the exporter was often sought by the buyer.

Now the buyer has come into his own again, he will not trouble himself about English; the exporter must learn the language of the customer. Now that so many of the powerful nations are again competing for the sale of their products, the exporter must take all possible aggressive measures. There is great need for capable men who have the adequate training and requirements to carry on our world-wide business.

In some cases men who are otherwise competent lack one of the main requisites, namely, a knowledge of foreign languages. This language question is one of the most serious ones in world market studies. In order to become an expert in any area an individual must know the language of that area. It is of course self-evident that language ability will not fit a man to do business in a foreign country any more than a knowledge of English will make any man a good salesman in America. The language, however, as a means of carrying on the business is absolutely essential and every effort must be put forth, to learn it as quickly as possible. Learning to read, write and speak a foreign tongue is not a short and easy task. There is a great dif- 
ferenee between an effeetive, fluent use of a language and a mere smattering knowledge of it. However, any one who applies himself diligently and earnestly to his task in a surprisingly short period of time can acquire a working knowledge of it-the rest is simply a matter of continued study and practice, but it is time well spent.

A salesman going to foreign markets other than Englishspeaking ones, must know either French or Spanish if he expects to compete successfully with other educated salesmen. Of the ten or twelve important commercial languages, Spanish, French and Portuguese are the most generally used. If any solid structure of foreign commerce relationships is to be laid, the correspondents, the traveling agents and at least some of the men of the business must be equipped to write and to converse intelligently on any subject in Spanish and French particularly, and in Brazil and Portugal, Portuguese is essential.

The French language has gained considerably in commercial importance since the war and on the whole is one of the most important foreign language for Americans to learn. The salesman going to France, Algeria, Moroeco, Belgium, Switzerland, Italy, Austria or the Balkan States must know French. While French is not the language of all these countries, it is the medium through which business can best be transacted in all of them. Now that America is trying to enter the markets of the Near East where French has long been the international language and since in South America large numbers of Latin Americans converse easily in this tongue, the importance of French, as a commereial language, is more and more apparent. But French is used far more extensively than solely in French territory. We find it the language of commercial, social and diplomatic eircles in Switzerland, Spain, Portugal, Italy, Greece, the Balkans, Turkey, Asia Minor, Persia, Russia, The Far East and Latin America. It has long been la langue diplomatique and employed at virtually all international conventions. Add to this the fact that it is a Romance language based upon Latin and 
a knowledge of it makes the acquisition of any of the other Romance languages such as Spanish, Italian, or Portuguese so much the easier, the distinct advantage of any one possessing a knowledge of it is evident.

Spanish is probably the next most important foreign commercial language, and the study of it is playing a much more important rôle in our edueational institutions than heretofore. It is the means of oral communication of two-thirds of the Amerieans who do not speak our language and with a thorough knowledge of it one can easily learn Portuguese, the language of the other third. It is the language of Spain, Mexico, Central America, Cuba and the West Indies, and nearly all of South America with the exeeption of Brazil. Together with English it is the prineipal language of the Philippines. It is considered by many as unquestionably the most important commercial language for North Americans to study.

To realize the commereial value of Spanish, we need only to eonsider that from 1900 to 1913 the total of all South American imports for all the world increased from $\$ 318,000,000$ to $\$ 1,042,000,000$. This increase was at the rate of 227 per cent as compared with an inerease of 107 per cent in our own imports and of 100 per cent in the trade of the whole world in the same period. During this time the population of Spanish America grew from 38,000,000 to nearly $60,000,000$, approximately 58 per cent inerease as compared with 28 pcr eent in the United States. The imports of Sonth Ameriea in 1913 averaged about $\$ 18.68$ per eapita in eomparison with $\$ 17.94$ per eapita importations in the United States. These figures plainly show the purehasing power of Latin Ameriea before the World War.

In order to give some idea of the possibilities for the future development of the South American countries, we state some of the faets from Geography Class by Dan Ward, in the World Outlook for February, 1915. Peru is the size of Spain, Franee, Italy and Germany eombined. Sixty Belgiums could be contained in Bolivia, still the latter has only one-third of Belgium's population. Chile 
is as long as from New York to San Franeisco and from 87 to 250 miles wide. All of the United States except Alaska could be contained in Brazil and there would still be a remainder of 200,000 square miles of Brazilian territory. Argentina has progressed more rapidly in the last ten years than Iowa or Illinois in the last fifty years. Buenos Aires (with 1,560,163 people) at the present rate of increase, will pass Chicago in 1930 and be the sceond city in size in the Western Hemisphere. Mexico City and São Paulo have approached the half million mark and six other eities either reached or passed the quarter million mark. These are only a few reasons why we should become acquainted as soon as possible with Latin American civilization, peoples and languages.

In learning a new tongue, one does not merely acquire a knowledge of the language. An entirely new field is opened to the student and he gains an insight into the course of mental development of the race. He has access to the heart and mind of the people. He learns their ideals, manners and customs. He gets a broader and more sympathetic understanding of mankind. $\mathrm{He}$ becomes acquainted with a new point of view, new mentality, new social usages, all of which is a distinct asset to his international equipment. He learns to think internationally. Too often has the eomplacent American had a tendency to disregard the importance of other languages. This condition is to be expected in our country where, in a district of hundreds of thousands of square miles, English is the only language of significance. Too often has he had a feeling of superiority over other nations which has been a decided detriment. In studying a new language he cannot help but acquire a broader outlook, overcome his former prejudices and on the whole have a mole comprehensive understanding of the world at large. He will then appreciate that there are millions whose view point is wholly different from ours and will make allowances for such differenees.

Primarily language is a tool and not a decoration-it 
is for use and not for cultural grace. The student of foreign trade is learning the language principally to be able to sell goods and conduct his business, but while learning, the language becomes a living thing to him and the cultural value is not lost. The literature of that country now becomes a delight. Many who understand a foreign language know the joy of reading a masterpiece in the original and then, sor the sake of comparison, sensing a keen loss when reading a translation of it in their own tongue, regardless of how fine that translation may be. Practical men are too prone to disregard this cultural value. Because one is a business man it does not follow that he should be solely interested in trade matters and commercial subjects. He should, of course, have a thorough knowledge of his own field, but at the same time if he is versatile and has read widely and intelligently on many subjects he will find it a distinct advantage.

Particularly does this appertain to Latin America where such subjects as art, literature, politics and history are especially appreciated and where business has often been secured through a friendship established not by brilliant salesmanship, but through some common interest apart from cold business.

In Latin America a salesman can hardly expect to accomplish more than a mere superficial skimming of the surface if he cannot speak Spanish, and any firm sending out such a salesman can hardly be taking the export problem very seriously. The use of an interpreter has been found very unsatisfactory. It places the salesman in an awkward and dependent position. He cannot possibly establish any friendship where there is no common medium for an intimate exchange of thoughts. On the other hand, the presence of the interpreter produces the wrong psychological effect. The foreigner cannot help but feel he is dealing with people whom he does not really know and with whom he is not on familiar ground. The personal element is almost entirely lost and usually the business also. We all know the importance of the personal element in 
conducting domestic business and it must be remembered that language is the root of the personal element. Any successful, permanent business in South America must be done by the use of the language of the country in which the business is transacted. The Germans and the English have shown the way in this respect by the careful training of their men in the speaking as well as the reading of Spanish and Portuguese before they reach Latin America. Now that these nations are competing again vigorously for Latin American trade, it is more urgent than ever if we wish to maintain the trade built up with these countries during the war, that our salesmen shall not be outclassed by competitors solely on account of their lack of linguistic equipment. This is a position no selfrespecting salesman would care to be placed in and he could not help but feel that he was doing his firm the grossest injustice because of this incompetency.

The majority of students make the mistake of supposing that all South America is alike. They think Spanish is the prevailing language of South America and believe that a knowledge of it will give them access to every part of that continent. They are entirely ignorant of the fact that the official language of Brazil, a republic as large as the United States with the exception of Alaska, is Portuguese. It is most important to realize that the republics of South America differ as widely as the separate states of Europe, in race, habits and ideals. Even their governments, although fundamentally the same, are quite dissimilar.

Because of the growing and future importance of trade relations with Brazil, that leviathan republic of South America with some 25,000,000 inhabitants, one can readily see the necessity of a knowledge of Portuguese. Add to this that there is more unexplored territory in Brazil than in all the rest of the world put together; that four-fifths of the world's coffee comes from that country and that Rio de Janeiro has a population of 1,128,637 people. All of these facts emphasize the importance of Portuguese as a 
commercial language. When we consider that there are only three tongues which are used as national languages in the important nations of this hemisphere [English, Spanish and Portuguese], it is very strange that German has been much more widely taught in our schools than Spanish which is second only to English in the language of the Americas, and comparatively little Portuguese. Something must be done to overcome the old traditions in our schools and give these languages, Spanish and Portuguese, the place they deserve in the eurriculum. Portuguese is the language used in Portugal, Brazil, the Spanish Province of Galicia, the Cape Verde Islands, Portuguese Guinea and other Portuguese colonies and is often regarded as third in commercial importance. It is the most Latinized of the Latin tongues and is less musical than any of them. In its form it resembles Spanish, its nearest neighbor, more than it does any of the other Romance languages, but it is considered by many as much more difficult and intricate. It has more vowel and consonant sounds and its pronunciation is much more arbitary. Using Spanish in Brazil for commercial purposes has a disparaging effect, since it makes the Brazilians feel that we do not think their country important enough to lcarn its language.

It would be possible, of course, for an American firm to engage a foreign agent thoroughly familiar with the language and general conditions of the local market. This, however, is not wholly satisfactory. The personality of the American business man is known the world over. His character stands for something distinct from all other business men. In choosing a foreigner as a local salesman, one naturally cannot expect him to be as enthusiastic as an American selling American goods and at the same time there cannot be the same loyalty of the foreigner to the American firm.

Trade Commissioner Eliot S. Mears in discussing this problem gave an interesting example of employing local salesmen in the Levant. In this particular district he says: 
The two great mistakes now being made are the general choice of a foreigner of local origin or of a foreigner who merely speaks any language other than English, irrespective of its use in the particular locality. An Armenian or Greek or Jew or Turk, irrespective of whether he has been naturalized or whether he represents a bona fide American company, is never regarded in commerce abroad as an American. He is still a Levantine and business negotiations with him are conducted on that plane.

Although this applies to the Levant, it is logical to assume that it applies to other foreign countries as well. As long as the character of our American business men is regarded as important by others it would be absurd not to recognize the value of it and make use of it.

All of this merely emphasizes the importance of the American business man learning foreign languages. As has been previously stated there are ten or twelve important commercial languages and when we consider that in each one of these there may be fifty different trade vocabularies, the impossibility of any one person studying languages for world trade in general is seen at once. Aside from those areas where French, Spanish and Portuguese are spoken, there are many divisions of the world where it will be necessary to learn to speak new and sometimes little known tongues. This is no difficult task in our large American cities. The individual, moreover, who is already engaged in business cannot usually choose to learn the language which appeals to him most-his choice is largely determined for him. His firm may be dealing largely with Latin America, in which case he would naturally study Spanish or Portuguese. However, if his house were interested in doing business with Russia, it would be to his advantage to study Russian.

In some of our institutions the need of teaching Russian from the commercial point of view has been felt but in comparison with England and even Scotland, the number of Americans interested in the study of this language is practically negligible.

In the United States we find a mere handful studying 
the Russian tongue whereas in England as far back as 1917 the number of students engaged in the study of Russian totaled 1,862 and in Scotland in the same year 566 students of Russian were reported; while in Germany hundreds are now reported as studying Russian in preparation for a Russian commercial invasion. When we consider that Russia has a population of $180,000,000$ in comparison with $80,000,000$ in Latin America and occupies one-seventh of the world's total area, the advisability of following the example set by these nations is quite obvious. It has been predicted by well-informed men of world affairs that within ten years our commercial relations with Russia, including Siberia, will greatly exceed those with all of Latin America. This prophecy is based upon the enormous population and the potential purchasing power in Russia. When order and industry prevail in this vast country there is certain to be a vast growth in her trade and eommerce with the rest of the world. There will then be large opportunities for those who have had the foresight to study Russian. It is a very difficult language to learn and there are comparatively few good teachers available. In many instances in the larger cities Russians can be found and, by seeking them out, any one who so desires has an opportunity to study conversational Russian with them. Frequently advantageous exchanges can be made-Russian in exchange for English.

The commercial importance of the German language will depend of course on the commercial importance of Germany itself in the future. While the military and political power of Germany has been broken, Germany in the course of time will surely come to play an important rôle among the nations of the world and her language will be correspondingly important. German is not only the language of Germany and Austria with some 70,000,000 people, but for commercial purposes is the most important foreign language in Holland, Norway, Denmark, Sweden and Finland.

No words of encouragement should be needed to stimulate 
the study of the language of Dante. As far as the Italian language is concerned, Italy ranks sixth among the countries of Europe with respect to population, coming next to France with a population of $35,000,000$ people. The language is of commercial importance not only in Italy, but throughout the Mediterranean region and particularly in Greece, Turkey, Asia Minor and North Africa.

In considering Chinese and Japanese, what we have previously stated regarding the Russian tongue applies also in the main to a study of Chinese and Japanese. China, the giant of the East, has a population of practically $411,000,000$ people. While their purchasing power per capita is small, in the aggregate it is large. China's trade has been steadily increasing and will continue to grow as soon as railway facilities enable the Chinese producer to dispose of his surplus products to the foreign trader. This cannot be accomplished at once, since the cost of transportation is extremely high. In order to convey some impression of what the future has in store for China, wo quote from an official report:

To form an idea of what future prospects are, it is fair to make a comparison with India. The areas of the two empires are almost identical and their products very similar. But China has a larger, more industrious and more intelligent population; while on the whole, the country is probably more fertile and possesses greater mincral resources. In the former country trade is assisted by good roads, railways, and lightness or absence of taxation; in the latter, at present, it is hampered by directly opposite conditions. The result is that the exports from India are worth three times the exports from China. With equal opportunities, which the building of railways and opening of mines will bring about. the discrepaney should disappear.

With the help of Westem capital and leadership China will become an increasingly important commercial power; those who will be able to communicate directly with her will have a distinct advantage in her developing commerce.

Our trade with Japan at present is already large and 
will no doubt continue to grow rapidly as it has in the past. A knowledge of Japanese would be of great value to any one carrying on business with the "Sunrise Kingdom." Like Russian, Chinese and Japanese are very difficult languages to learn and competent teachers are scarce. However, any one who is sufficiently interested can usually find a means for accomplishing his end.

To those who have no access to personal teachers, correspondence courses in the important commercial languages are ofiered by many university extension departments and private schools. By this method a student ear. at least acquire a reading and writing knowledge of the language which will enable him to learn the spoken language more readily.

In this connection there are phonograph language courses which produce good results by affording practice in the spoken language. The best known of these is perhaps the Cortina Method.

For the benefit of those who may be interested in language study we give the following texts and references in the various important commercial languages. These books have been carefully selected and many of them have proved valuable in their use and practical application in the larger commercial educational institutions. In the ease of French, Spanish and German, for such students who have acquired a reading knowledge of the language and who are anxious to continue their study with more difficult texts, we have added a list of novels and other interesting reading material. For a general comprehensive commercial dictionary we suggest Pitman's Dictionary of Commercial Correspondence in Seven Languages, covering English, French, German, Spanish. Italian, Portuguese and Russian. 


\section{BOOKS AS AIDS FOR ACQUIRING LANGUAGES}

\section{French:}

ALDRICH \& FOSTER: Elementary French.

Becker \& PoOLe: Commercial French Reader.

Bercy, Paul: Le Français Pratique. (New York, Jenkins, \$1.10.)

Bierman \& Frank: Conversational French Reader. (Allyn \& Bacon.)

Blanchaud: Progressive French Idioms. (D. C. Heath \& Co., $\$ .60$.

Chardenal: French Grammar.

CoRnett, W. N.: French Commercial Correspondence. (Milwaukee, Casper, \$.75.)

DaNN \& Courvoler: French Commercial Correspondence. (London, Asher \& Co., 13 Bedford Street.)

Downer, Charles A.: A First Book in French. (D. Appleton \& Co., \$1.60.)

Fontaine: Livre de Lecture et de Conversation. (D. C. Heath $\&$ Co., \$.90.)

François, Victor: Introductory French Prose Composition. (American Book Co.)

FraSer \& Squair: Complete French Grammar. (D. C. Heath $\&$ Co., \$1.15.)

GaUdeL, V. D.: The Ideal System for Acquiring a Practical Knowledge of French. (Published by the author at $121 \mathrm{~W}$. 70th Street, N. Y. C., \$1.50.)

Graham \& Oliver: Commercial Correspondence, Parts $I$ and II.

Holbrook, R. T.: Course in Living French. (Ginn, \$1.40.)

Hotchusss: Le Premier Livre de Français. (D. C. Heath \& Co., \$.35.)

KORTS, G.: Commercial Term. (London, Hachette.)

Maloubier \& Moore: First Book.

Patrerson, W. R.: Colloquial French. (E. P. Dutton \& Co., \$1.25.)

RAUX: Elementary French Reader.

ThimM, Franz: Easy Method for Learning French Quickly. (New York, Wehman Bros.) 
The following books published by I. Pitman \& Sons will be of use, for commercial purposes:

PitMan : Commercial French Grammar.

- French Commercial Correspondence.

- French Commercial Reader.

-Mercantile Correspondence, English-French.

We would also suggest material from Le Temps, Le Matin, L'Illustration or La Revue Bleue as well as any of the following:

Benton: Easy French Plays.

BRuno: Le Tour de la France.

Daddet: Le Petit Chose.

HaLÉvY: L'Abbé Constantin.

Hugo: Quatre-vingt-treize and also Les Misérables.

Loti, Pierre: Pêcheur d'Islande.

MoLiepe: Le Bourgeois Gentithomme.

- Livare.

Krone: Le Petit Parisien.

LAVISSE: Histoire de France.

MaLot: Sans Famille.

OsGood: La France Héroïque. (D. C. Heath \& Co.)

Pattou: Causeries en France. (D. C. Heath \& Co., \$.70.)

Tourists' Vade Mecum of French Colloquial Conversation.

Pitman \& Sons.)

For a good dictionary we recommend the following:

HeATH: French Dictionary (\$1.50.)

Sмiтн, F. W.: French-English and English-French Commercial Dictionary. (T. Pitman \& Sons.)

Spiers \& Surenne: Complete French and English Dictionary. (D. Appleton \& Co., \$2.50.)

Wessly, J. E.: French-English Dictionary. (A. L. Burt Co., $\$ 1.00$.

Spanish:

Allen \& Casttllo: Spanish Life. (Henry Holt \& Co.)

Bonilla: Spanish Daily Life.

BroomhalL, E. J.: Spoken Spanish. (Allyn \& Bacon, \$.60.) 
De Tornos, A.: Combined Spanish Method. (Appleton, \$2.00.) Espinosa, A. M.: Advanced Composition and Conversation. (Sanborn \& Co.)

Fuentes \& Elias: Manual de Correspondencia Commercial.

Fuentes \& Françors: Practical Spanish Grammar.

Giese, W. F.: A First Spanish Book and Reader. (D. Appleton \& Co., \$1.72.)

Graham and Oliver: Spanish Commercial Practice. (Macmillan Co., Part I, \$.75, Part II, \$1.05.)

Harrison, E. S.: A Spanish Commercial Reader. (Ginn \& Co., \$.96.)

HaRRISON: Spanish Correspondence. (Henry Holt \& Co., \$.75.) Hills AND Ford: First Spanish Course. (D. C. Heath \& Co., $\$ 1.28$.

LuRIa: Correspondencia Commercial. (Silver, Burdett \& Co., \$1.25.)

MacDonald, G. R.: Lessons in Spanish Commercial Correspondence. (I. Pitman \& Sons.)

MCHale, C. F.: Commercial Spanish. (D. C. Heath \& Co., \$1.48.)

-Spanish Taught in Spanish. (Houghton Mifflin Co., \$1.00.) Nelson, Ernesto: The Spanish American Reader. (D. C. Heath \& Co.)

Pittaro, John M.: A Spanish Reader. (D. C. Heath \& Co., \$1.32.)

Roessler ANd Rejry: First Spanish Reader. (American Book Co.)

Romero, T.: Spanish, Commercial and Professional. McKay, Philadelphia, \$.75.)

-Spanish in a Week. (Philadelphia, \$.50.)

Sinagran: Foundation Course in Spanish, Parts I, II, III. (Macmillan Co.)

Toledano: Commercial Spanish Grammar. (I. Pitman \& Sons.)

TurRell: Spanish Reader. (American Book Co., \$.72.)

Umphrey: Spanish Prose Composition. (American Book Co., $\$ .69$.)

Wilkins, L. A.: Elementary Spanish Prose Book. (Sanborn Co.)

YbarRa, A.: A Practical Method of Learning Spanish. C. Heath \& Co., \$1.00.)

-Spanish Business Conversations and Interviews. (1. Pitman \& Sons.) 
For practical application extracts from the daily newspaper, La Prensa, are recommended. For interesting reading we suggest the following:

alarcón: El Capitan Veneno. (D. C. Heath \& Co.)

-Novelas Cortas. (D. C. Heath \& Co., \$.42.)

Bardin, JaMes, editor: El Reina des los Incas del Peru. (Allyn \& Bacon, \$1.00.)

Benavente, Jacinto: Tres Comedias. (D. C. Heath \& Co., \$.72.)

Coester, Alfred: Cuentos de la America Española. (Ginn $\&$ Co.)

Dorado, Carolina: España Pintoresca. (Ginn \& Co., \$.96.)

Galdos: Doña Perfecta.

IbaNez, Blasco: La Batalla del Marne. (D. C. Heath \& Co.)

IsaAcs, Jorge: Maria. (Ginn \& Co.)

Laguardia and Laguardia: Argentina-Legend and History. (Sanborn \& Co., \$1.25.)

TABOADA: Cuentos Alegres. (D. C. Heath \& Co.)

-Zaragueta. (Silver Burdett \& Co.)

-El Comendador Mendoza. (American Book Co., \$.75.)

For a good dictionary any one of the following:

APPLETON: New Spanish-English and English-Spanish Dictionary, indexed by A. Cuyas. (D. Appleton \& Co., \$3.50.) MACDONALD, G. R.: Spanish-English and English-Spanish Commercial Dictionary. (I. Pitman \& Sons.)

McLadghlin: New Pronouncing Dictionary. (Philadelphia, D. McKay, $\$ 1.50$.)

\section{Portuguese:}

Branner, John C.: A Brief Grammar of the Portuguese Language. (Henry Holt \& Co., \$1.50.)

-Segundo Livre de Leitura.

DA CunHa, E.: Portuguese Self-Taught. (New York, Stechert, $\$ .75$.

Elwes, Alfred: Portuguese Grammar. (Appleton, \$1.50.)

Elwes, Alfred: Portuguese English and English Portuguese Dictionary. (Appleton, $\$ 3.50$.)

Ely, L.: Portuguese Conversational Grammar. (New York, Stechert, $\$ 1.50$.) 
Escobar, J. F.: New Methods to Learn the Portuguese Language without Teacher. (Published by the author at New Bedford, Mass., \$2.00.)

GaRva: Prosas Simples.

Goodell : Commercial Reader.

MacDonald, G. R.: Lessons in Portuguese Commercial Correspondence. (I. Pitman \& Sons.)

Manual of Portuguese and English Conversation. (Obtainable from Stechert, N. Y., \$.50.)

Pitman: Mercantile Correspondence, English-Portuguese. Pitman \& Sons.)

Thomas, Frank: A Portuguese Grammar (Hossfeld's Method). (Philadelphia, P. Reilly, \$1.25.)

Toledano, C. A. \& Toledano, A.: A Practical Grammar of the Portuguese Language. (I. Pitman \& Sons.)

The best dictionary is A New Dictionary of the Portuguese and English Languages by $\mathrm{H}$. Michaelis which contains not only the expressions from the language of daily life but also many technical terms used in commerce and industry and in the arts and scienecs. It is published in two volumes by I. Pitman \& Sons; the first volume being devoted to Portuguese-English and the second to EnglishPortuguese.

\section{German:}

Baumback: Die Nonna.

BIERWIRTH: The Elements of German.

Bithell, Jethro: Handbook of German Commercial Correspondence. (Longmans, Green \& Co.)

Collins, Bagster : First Book in German.

EICHENDORF: Aus dem Leben eines Taugenichts.

Freytag: Die Journalisten and also Sell und Haben.

Fulda: Unter vier Augen.

GeRSTACKER: Germelshausen.

GrahaM: German Commercial Practice. (Macmillan Co.)

Grossman: Practical Guide to German Pronunciation.

HaRRIS: German Lessons. (D. C. Heath \& Co., \$.60.)

JoYNes: Wesselhoeft Grammar.

KELlER: Romeo und Julia auf dem Dorfe.

KroN: German Daily Life. 
Kutner, Arnold: German Commercial Correspondence. (American Book Co.)

LAMBERT: Handbook of German Idioms.

LEANDER: Träumereien.

Lessing: Minna von Barnhelm.

Lutz: An Elementary German Reader. (Silver, Burdett \& Co.) MeIssner: Aus meiner Welt.

Pattou: An American in Germany. (D. C. Heath \& Co., $\$ .70$.

POPE: Writing and Speaking German. (Henry Holt \& Co.) RIEHL: Fluch der Schönheit.

Roessler: A First German Reader. (American Book Co.) SCHILLER: Wilhelm Tell.

SeEliguad: Altes und Neues.

SToRM: Immensee and also In St. Jurgen.

Thomas: A Practical German Grammar.

Wienr: German Prose Composition. (Oxford University Press.)

Wildenbruch: Das Edle Blut and also Der Letzte.

Zinnacker: Deutsch für Anfänger. (D. C. Heath \& Co.)

Reading of the New York Staatszeitung.

For a practical dictionary we recommend Heath's German Dictionary by E. Wier, $\$ 1.50$.

\section{Italian :}

Arbib-Costa: Italian Lessons and Advanced Italian Lessons.

CONNOR, J.: Conversation Book in English and Italian for the Use of Schools and Travelers. (Brentano, \$.60.)

Elwes, Alfred: Italian Grammar. (D. Appleton \& Co., \$1.50.) Hossfeld: English and Italian Dialogues. (P. Reilly, \$.45.)

-Idiomatic Italian Composition. (P. Reilly, \$.60.)

-Italian Conversation Grammar, Method Gaspey-Otto-Sauer. (Brentano, \$1.00.)

MARINoni, A.: Italian Reader.

MelzI: Italian-English, English-Italian Dictionary. (Philadelphia, P. Reilly, \$2.00.)

Motti, Pietro; Elementary Italian Grammar. (Brentano, $\$ .50$.)

Phelps: An Italian Grammar. (Ginn \& Co.)

Pitman: Mercantile Correspondence English-Italian. (I. Pitman \& Sons.) 
Ricci, Luigi : Pitman's Commercial Italian Grammar. (I. Pitman \& Sons, \$1.10.)

Rota, A.: New Practical Method for Learning the Italian Language, Hossfeld Method. (Philadelphia, P. Reilly, \$1.25.) Scotri, DR. C.: Italian Reader. (Philadelphia, P. Reilly, $\$ .60$.)

\section{Chinese:}

Brouner, W. B.: Chinese Made Easy. (Macmillan Co.)

Bullock, T. L.: Progressive Exercises in the Chinese Written Language. (New York, Stechert, \$3.75.)

DARROCH, J.: Chinese Self-Taught.

Hillier, W. C.: The Chinese Language and How to Learn It. Poster, A.: Elementary Lessons in Chinese. (New York, Oxford University Press, $\$ 12.00$.)

A Practical Chinese-English Grammar by Dr. Chen of Georgetown University, Wash., D. C. is to be published shortly and should be of inestimable value.

The best dictionary for the spoken language is that by $D$. MacGillioray: Mandarin-Romanized Dictionary of Chinese. (New York, Stechert, \$7.50.)

\section{Japanese:}

Aston, W. G.: Grammar of the Japanese Written Language. - Grammar of the Japanese Spoken Language.

Chamberlain, B. H.: Handbook of Colloquial Japanese. (Yokohama, Kelly \& Walsh Co.)

- A Practical Introduction to the Study of Japanese Writing. (London, C. Lockwood \& Sons.)

Hepburn, J. C.: Japanese and English Dictionary. (New York, Stechert, \$1.75.)

HoSSFELD: English-Japanese Grammar by A. J. Weintz. (Philadelphia, P. Reilly, \$1.25.)

- Japanese Reader, Part I \& II. (Philadelphia, P. Reilly, $\$ 1.25$.

IMRRIE: Handbook of English-Japanese Etymology.

LANGE, R. K.: Textbook of Colloquial Japanese. (New York, Stechert, $\$ 5.00$, standard work.)

Plaut, H.: Japanese Conversation Grammar. (Brentano.)

Prentys and Sasamoto: Japanese for Daily Use.

Satow \& WaSAKata: English-Japanese Dictionary of the Spoken Language. 
Shand, W. S.: Japanese Self-Taught. (Now York, Stechert, $\$ .75$.

ShebA, S.: Practical English-Japanese and Japanese-English Conversations.

Russian:

Alexandroff, A.: Complete Russian Engiish Dictionary. (Obtainable from Stechert, N. Y., \$14.00. Best Dictionary.) -A Practical Method of the Russian Language.

BAEDEKER, K.: Manual of the Russian Language with vocabulary and list of phrases. (Scribner's Sons, \$.45.)

BONDAR: Simplified Russian Method.

Chevob-Maurice: English-Russian Commercial Correspondence. Forbes, Neville: Russian Grammar. (New York, Oxford University Press, \$2.00.)

Freese, J. H.: A Russian Manual. (E. P. Dutton \& Co., $\$ 1.25$.

Harper, S. N.: Russian Reader. (University of Chicago Press.)

Hill: Vest Pocket English-Russian Dictionary. (Philadelphia, D. Mckay.)

Hossfeld: New Practical Method for Learning the Russian Language by Rappoport. (Philadelphia, Reilly, \$1.00.)

KaRRACHY-SMITH: Lessons in Russian.

Mangus, L. A.: Concise Grammar of the Russian Language. Motti, Pietro: Russian Conversation, Grammar and Key. (London, D. Nutt.)

Riola, H.: Graduated Russian Reader. (E. P. Dutton \& Co., $\$ 1.75$.

-How to Learn Russian. (E. P. Dutton \& Co., \$2.00.) Sieff: Manual of Russian Commercial Correspondence.

P. Dutton \& Co.)

Solomonofy, J.: Russian Composition, Parts I, II, III. Wassilieff, A.: Russian Dictionary. (Chas. Scribner's Sons.) -Russian Made Easy. (I. Pitman \& Sons, \$1.00.)

-What You Want to Say and How to Say It in Russian. (New York, W. J. Herman.) 


\section{CHAPTER XII}

\section{DEFINITIONS OF FOREIGN TRADE TERMS}

He shall be as a god to me who ean rightly divide and define.-Plato.

The work of the National Foreign Trade Council, which held its seventh convention, May 12th to 15th, 1920, in San Francisco, has accomplished for American foreign trade valuable and extensive services since the inception of the Council in the early part of 1914.

This body of representative American business men has held seven large conventions in different parts of the United States. The organization also has held to a continuous advocacy of such fundamental foreign trade necessities as were exemplified by the passing of the Webb Law; support of the idea of the American Merchant Marine; a bargaining tariff sufficiently flexible to prevent any discrimination against American goods; and expending constant effort to promote better trade communication facilities and removing barriers obstructing our trade and rendering competition difficult with other nations. For the championship of these and other prime issues, the Foreign Trade Council has become a most valuable institution in our commercial life.

Among the most important services rendered to American foreign business by this Council is its explicit findings in regard to standard definitions and practices recommended to merchants, shippers and exporters doing business with other nations. There have been so many variations and such a lamentable lack of knowledge on the part of many new shippers concerning the exact method and means of 
marketing American goods abroad that some authoritative standard of procedure was greatly needed. We believe that this pronouncement of the National Foreign Trade Council should be studied with the utmost care by every American manufacturer or merchant who expects to succeed in his business abroad.

Just what obligations familiar terms, such as "F.O.B.," "C.I.F.," etc., impose upon seller, buyer, shipowner, banker and all others affected by the transaction is set forth in a report issued by the Council on behalf of the leading commercial organizations of the United States.

Half the troubles in foreign trade arise from misinterpretation of such terms. Even old merchants will do well to read and study the following injunctions and standard explanations which have been agreed upon by the members of the National Foreign Trade Council.

One of the subjects which has given the foreign merchant cause for complaint has been the methods which the newer exporters in the United States have employed in making price quotations to foreigners. The dissatisfaction of foreign purchasers reached a head in the summer of 1919, in the form of organized protests from Australian importers over the meaning given to the terms "F.O.B. New York" by American exporters. The National Foreign Trade Council took up the matter, decided that in the best Ameriean practice "F.O.B. New York" means free on board overseas vessel at New York, and notified its numerous correspondents of this fact and of the recommendation of the council that the term "F.O.B. vessel New York' be submitted in all cases for the term "F.O.B. New York."

So much interest was aroused by this communication, and so many other questions of a similar nature arose, that it was decided to hold a conference of the nine great foreign trade organizations of the country, in order to agree on the obligations of buyer and seller, under the export quotations in most common use. Such a conference was held in India House, New York, under the auspices of the National Foreign Trade Council, on December 16, 
1919. The organizations participating in the conference were the National Foreign Trade Council, Chamber of Commerce of U. S. A., National Association of Manufacturers, American Manufacturers Export Association, Philadelphia Commercial Museum, American Exporters and Importers Association, Chamber of Commerce of the State of New York, New York Produce Exchange, New York Merchants Association. The meeting discussed at length all phases of American export practice, and issued a statement of definitions and recommendations agreed upon.

As the most certain means of insuring unmistakable clarity in terms and conditions of sale, the conference voted to recommend to manufacturers and exporters that all use of abbreviated forms of export price quotations be abandoned, and that such terms be written out in full.

The Conference recognized, however, that this recommendation is not likely to be accepted generally at once; and, therefore, in the hope of effecting a simplification and standardization of American practice, it adopted the following statement of definitions of the abbreviated forms in more common and general use in the export trade. The Conference strongly recommends to manufacturers and exporters that wherever abbreviated forms of export quotations are employed, the forms herein defined be used, as far as possible, to the exclusion of other forms.

These are, in their order, the normal situations on which an export manufacturer or shipper may desire to quote prices. It is understood that unless a particular railroad is specified, the property will be delivered to the carrier most conveniently located to the shipper. If the buyer, for the purpose of delivery, or in order to obtain lower transportation charges, desires that the goods be delivered to a carrier further removed from the shipper and entailing a greater cost than delivery to the carrier most favorably situated, the carrier to which the buyer desires delivery of the goods should be named in the quotation. The term "cars or lighters," as used herein, is intended to include river, lake or coastwise ships, canal boats, barges, or other 
means of transportation, when so specified in the quotation.

I. When the price quoted applies only at inland shipping points and the seller merely undertakes to load the goods on ${ }^{\circ}$ in cars or lighters furnished by the railroad company serving the industry, or most conveniently located to the industry, without other designation as to routing, the proper term is:

\section{F.O.B. (named point).}

Under this quotation:

A. Seller must

1. Place goods on or in ears or lighters.

2. Secure railroad bill of lading.

3. Be responsible for loss and/or damage until goods have been placed in or on ears or lighters at forwarding point, and clean bill of lading has been furnished by the railroad company.

B. Buyer must

1. Be responsible for loss and/or damage incurred thereafter.

2. Pay all transportation charges including taxes, if any.

3. Handle all subsequent movement of the goods.

II. When the seller quotes a price including transportation charges to the port of exportation without assuming responsibility for the goods after obtaining a clean bill of lading at point of origin, the proper term is:

F.O.B. (named point) Freight Prepaid to (named point on the seaboard).

Under this quatation:

A. Seller must

1. Place goods on or in ears or lighters.

2. Secure railroad bill of lading.

3. Pay freight to named port.

4. Be responsible for losis and/or damage until goods have been placed in or on cars or lighters at forwarding point, and clean bill of lading has been furnished by the railroad company. 


\section{B. Bayer must}

1. Be responsible for loss and/or damage incurred thereafter.

2. Handle all subsequent movements of the goods.

3. Unload goods from cars.

4. Transport goods to ressels.

5. Pay all demurrage and/or storage charges.

6. Arrange for storage in warehouse or on wharf where necessary.

III. Where the seller wishes to quote a price, from which the buyer may deduct the cost of transportation to a given point on the seaboard, without the seller's assuming responsibility for the goods after obtaining a clean bill of lading at point of origin, the proper term is:

F.O.B. (named point) Freight Prepaid to (named point on the seaboard).

Under this quotation:

A. Seller must

1. Place goods on or in cars or lighters.

2. Secure railroad bill of lading.

3. Be responsible for loss and/or damage until goods have been placed in or on cars or lighters at forwarding point, and elean bill of larling bas been furnished by the railroad company.

B. Buyer must

1. Be responsible for loss and/or damage incurred thereafter.

2. Pay all transportation charges (buyer is then entitled to deduct from the amount of the invoice the freight paid from primary point to named port).

3. Handle all subsequent movement of the goods.

4. Unload goods from cars.

5. Transport goods to vessel.

6. Pay all demurrage and/or storage charges.

7. Arrange for storage in warehouse or on wharf where necessary.

IV. The seller may desire to quote a price covering the transportation of the goods to seaboard, assuming respon- 
sibility for loss and/or damage up to that point. In this case, the proper term is :

F.O.B. cars (named point on seaboard).

Under this quotation:

A. Seller must

1. Place goods on or in ears.

2. Secure railroad bill of lading.

3. Pay all freight charges from forwarding point to port on seaboard.

4. Be responsible for loss and/or damage until goods have arrived in or on ears at the named port.

B. Buyer must

1. Be responsible for losis and/or damage incur'ed thereafter.

2. Unload goods from cars.

3. Handle all subsequent movement of the goods.

4. Transport goods to vessel.

5. Pay all demurrage and/or storage charges.

6. Arrange for storage in warehouse or on wharf where necessary.

V. It may be that the goods, on which a price is quoted covering the transportation of the goods to the seaboard, constitute less than a carload lot. In this case, the proper term is:

F.O.B. cars (named port) L.C.L.

Under this quotation:

A. Seller must

1. Deliver goods to the initial carrier.

2. Secure railroad bill of lading.

3. Pay all freight charges from forwarding point to port on seaboard.

4. Be responsible for loss and/or damage until goods have arrived on cars at the named port.

B. Buyer must

1. Be responsible for loss and/or damage incurred thereafter.

2. Handle all subsequent movement of the goods.

3. Accept goods from the carrier. 
4. Transport goods to vessel.

5. Pay all storage charges.

6. Arrange for storage in warehouse or on wharf where necessary.

VI. Seller may quote a price which will include the expense of transportation of the goods by rail to the seaboard, including lighterage. In this case, the proper term is :

F.O.B. cars (named port) Lighterage Free.

Under this quotation:

A. Seller must

1. Place goods on or in cars.

2. Secure railroad bill of lading.

3. Pay all transportation charges to, including lighterage at, the port named.

4. Be responsible for loss and/or damage until goods have arrived on cars at the named port.

B. Buyer must

1. Be responsible for losis and/or damage incurred thereafter.

2. Handle all subsequent movement of the goods.

3. Take out the insurance necessary to the safety of the goods after arrival on the cars.

4. Pay the cost of hoisting goods into vesisel where weight of goods is too great for ship's tackle.

5. Pay all demurrage and other charges, except lighterage charges.

VII. The seller may desire to quote a price covering delivery of the goods alongside overseas vessel and within reach of its loading tackle. In this case, the proper term is :

F.A.S. vessel (named port).

Under this quotation:

A. Seller must

1. Transport goods to seaboard.

2. Store goods in warehouse or on wharf, if necessary, unless buyer's obligation includes provision of shipping facilities. 
3. Place goods alongside ressel either in a lighter or on the wharf.

4. Provide the usual dock or ship's receipt.

5. Be responsible for loss and/or damage until goods have been delivered alongside the ship or on wharf.

B. Buyer must

1. Be responsible for loss and/or damage thereafter, and for insurance.

2. Handle all subsequent movement of the goods.

3. Pay cost of hoisting goods into vessel where weight of goods is too great for ship's taekle.

VIII. The seller may desire to quote a price covering all expenses up to and including delivery of the goods upon the overseas vessel at a named port. In this case, the proper term is:

F.O.B. vessel (named port).

Under this quotation:

A. Seller must

1. Meet all charges incurred in placing goods actually on board the vessel.

2. Provide the usual dock or ship's receipt.

3. Be responsible for all loss and/or damage until goods have been placed on board the vessel.

B. Bnyer must

1. Be responsible for loss and/or damage thereafter.

2. Handle all subsequent morement of the goods.

IX. The seller may be ready to go farther than the delivery of his goods upon the overseas vessel and be willing to pay transportation to a foreign point of delivery. In this case, the proper term is:

C. \& F. (named foreign port).

Under this quotation:

A. Seller must

1. Make freight contract and pay transportation charges sufficient to carry goods to agreed destination.

2. Deliver to buyer: or his agent clean bills of lading to the agreed destination. 
3. Be responsible for loss and/or damage until goods bave been delivered alongside the ship and clean ocean bill of lading obtained (seller is not responsible for delivery of goods at destination).

B. Buyer must

1. Be responsible for loss and/or damage thereafter and must take out all necessary insurance.

2. Handle all subsequent movement of the goods.

3. Take delivery and pay costs of discharge, lighterage and landing at foreign port of destination in aceordance with bill of lading clauses.

4. Pay foreign customs duties and wharfage charges, if any.

$\mathbf{X}$. The seller may desire to quote a price covering the cost of the goods, the marine insurance on the goods, and all transportation charges to the foreign point of delivery. In this, the proper term is:

C.I.F. (named foreign port). Under this quotation:

A. Seller must

1. Make freight contract and pay freight charges sufficient to carry goods to agreed destination.

2. Take out and pay for necessary marine insurance.

3. Deliver to buyer or his agent clean bills of lading to the agreed destination, and insurance policy and/or negotiable insurance certificate.

4. Be responsible for loss and/or damage until goods have been delivered alongside the ship, and clean ocean bill of lading and insurance policy and/or negotiable insurance certificate have been delivered to the buyer, or his agent. (Seller is not responsible for the delivery of goods at destination, nor for payment by the underwriters of insuranee claims.)

5. Provide war risk insurance, where necessary, for buyers' aceount.

B. Buyer must

1. Be responsible for loss and/or damage thereafter, and must take all claims to which he may be entitled under the insurance directly on the underwriters. 
2. Take delivery and pay costs of discharge, lighterage and landing at foreign port of destination in accordance with bill of lading clauses.

3. Pay foreign customs duties and wharfage charges, if any.

\section{Explanations of Abbreviations}

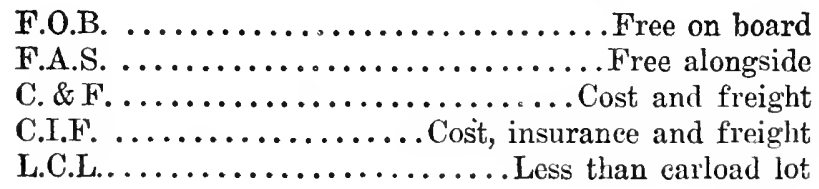

In reaching the conclusions set forth in this statement the Conference considered the fact that there are, in more or less common use by manufacturers in different parts of the United States, numerous variations of these abbreviations practically all of which are employed to convey meanings substantially synonymous with those here defined. For instance, there are manufacturers who quote "F.O.B. Cars," "F.O.B. Works," "F.O.B. Mill," or "F.O.B. Factory," meaning that the seller and buyer have the same responsibilities as those set forth in section 1 . The Conference considered all those variations and determined to recommend the use of "F.O.B. (named point)," as "F.O.B. Detroit," "F.O.B. Pittsburgh," cte. Of the considerable number of these abbreviations which are used in the United States, the Conference felt that the form "F.O.B. named point)" is most widely used and understood, and therefore, should be adopted as the standard of practice.

The chief purpose of the Conference is to simplify and standardize American practice, and to that end it urges manufacturers and exporters to cease the use of synonymous abbreviations and quote habitually in the terms here recommended, just as far as these terms will cover the price conditions which it is desired to arrange with the buyer.

Variations of the abbreviations recommended in other sections also are in more or less common use throughout 
the United States. The reeommendations of the Conference set forth above apply to them with the same force as to those cited under section $I$.

Manufacturers and exporters are urged to bear in mind that the confusion and controversies which have arisen have sprung in part from the use of an excessive number of abbreviated forms with substantially similar meanings, as well as from the use of abbreviations in a sense different from their original meanings, or in an application not originally given them and different from the sense or application understood by foreign buyers.

In simplified and standardized practice lies the best hope of reducing confusion and avoiding controversy.

The Conference urges upon manufacturers and exporters the very great importance at all times of making their intention in whatever quotations they employ so thoroughly clear as to be impossible of misunderstanding or misinterpretation. It is much better to take the time and space at the outset to make the quotation clearly understood, than to be compelled in the end to go through vexatious controversy or litigation, which costs not only time and expense but customers as well. Misunderstandings can best be avoided if the seller will formulate a written statement of the general conditions under which his sales are to be made, and will see that the foreign buyer possesses these terms of sale when considcring a quotation. The items which may be included in such a statement, deal with: delivery, delays, partial shipments, shipping instruetions, inspection, claims, damage, and payment. If all contingencics are thus covered by carefully considered conditions of sale, disputes will largely be prevented.

The quotation "F.O.B. (named port)" as "F.O.B. New York," "F.O.B. Ncw Orleans," "F.O.B. San Francisco," is often used by inland producers and distributors to mean merely delivery of the goods at railway terminal at the port named. This abbreviation originated as an export quotation and had no application to inland shipments. It was used only to mean delivery of the goods upon an over- 
seas vessel at the port named. That, in fact, is the meaning universally given to the phrase among foreigners, and is the meaning which the best practice among exporters requires it invariably to have. But because of the confusion which has arisen through the use of that form with a different meaning by inland producers and distributors, and in the interest of unmistakable clarity, the Conference most strongly urges the invariable use by American manufacturers and exporters of the form "F.O.B. vessel (named port)." This adds only one word to the abbreviated form and has the great advantage that it cannot be misunderstood. It also avoids the difficulty which might arise among foreigners not always well versed in American geography, through confusing an inland forwarding point with a shipping port at seaboard.

The Conference calls attention to the fact that in selling "F.A.S. vessel" manufacturers and exporters should be careful to have their agreements with buyers cover explicitly the question of responsibility for loss after goods have been delivered on the wharf or alongside the vessel and before they are actually loaded on the ship. There is no generally established practice on this point. The recommendation of the Conference in the definitions of responsibility under section VII, sets up a rule which it is hoped will lead to the establishment of a standard practice.

It is understood that the provision of lighterage covered in several of these recommendations is anly within the usual free lighterage limits of the port, and that where lighterage outside such limits is required, it is for buyer's account.

In order to avoid confusion in another particular, attention is called to the care which must be exercised in all cases in making weight quotations. The net ton, the gross ton and the metric ton all differ in weight. Similarly there is a variation in the use of the term "hundredweight" to mean either 100 pounds or 112 pounds. It is, therefore, not sufficient to quote a price per "ton" or per "hundredweight." Instead the Conference recommends 
the use of the terms "ton of $2000 \mathrm{lbs}$," "ton of $2240 \mathrm{lbs.,"}$ or "ton of 2204 lbs.," etc., whichever is intended.

It is also important to note that a carload lot in the United States means the quantity of the particular commodity in question necessary to obtain the carload freight rate for transportation on American railways. This quantity varies aceording to the commodity and also varies in different parts of the country. Certain commodities being more bulky than others, the minimum carload for them is less than for heavier products oceupying less space. The load required may range anywhere from 12,000 to 90,000 pounds. Consequently, it is important, when quoting prices applicable to carload lots, to state and to specify the minimum weight necessary to make a carload lot of the particular commodity for the partieular shipment in question.

The Conference points out that in quoting "C.\& F." or "C.I.F.," manufacturers and exporters moving large quantities of material by one vessel should be careful to aseertain in advance the buyer's capacity to take delivery. This beeause, under these terms and as a condition of making the freight rate, transportation companies may require a certain rate of diseharge per day, and that rate of diseharge might be in excess of the buyer's capacity to take delivery. In sueh event an adjustment with the transportation company would be necessary, which might affect the freight rate and consequently the price to be quoted.

The Conference also strongly urges shippers clearly to understand the provisions of their insuranee protection on all foreign sales, irrespective of the general terms used thereon. In almost all cases it should be possible, when making shipments by steamer, to obtain insurance cover giving full protection from primary shipping point to designated sea port delivery, and/or foreign port delivery. As ordinary marine insurance under F.P.A. conditions, that is, free of partieular average, gives no protection against deterioration and/or damage to the merchandise itself while in transit, when caused by the recognized 
hazards attending such risks, shippers should endeavor in all cases to obtain insurance under W.P.A. (S.P.A.) conditions, that is, with particular average (subject to particular average), when in excess of the customary franchise of 3 per cent to 5 per cent. Under such form of insurance, underwriters will be called upon to pay claims for damages when these exceed the stipulated franchise.

The Conference points out that in as much as fees for consular invoices and similar items are arbitrary charges fixed by foreign governments, they are not included in the terms of C. \& F. or C.I.F. quotations, and it is part of the duty of the buyer to meet them.

Finally, the Conference strongly recommends, as a most effective measure of simplification, the general practice of quoting for export, as far as possible, either "F.A.S. vessel," or "F.O.B. vessel," or "C.I.F." Concentration on this small list, all of which terms are readily understood abroad and are difficult of misinterpretation, will, it is felt, be markedly influential in avoiding confusion and controversy.

The conelusions and definitions set forth above are the recommendations of a Conference which was composed of representatives of nine of the great commercial organizations of the United States interested in foreign trade. Not all have as yet the force of law or long established practice; but it is the hope and expectation of the Conference that these recommendations will receive such adherence on the part of American producers and distributors, as to make them in fact the standard American practice. And it is, therefore, expected that in due time they will receive the sanction of legal authority. 


\section{CHAPTER XIII}

\section{THE HOUSE ORGAN IN FOREIGN TRADE}

Although the establishment of magazines by both domestic and also foreign trade firms for the purpose of benefiting their employees, as well as for business propaganda generally, has reached an extensive stage, the entire movement has need of serious study not only by the editors of these papers, but also by business houses themselves. As a matter of fact, a large number of firms where these magazines have been started and are still being carried on have not taken the magazine seriously as a vital and necessary part of the firm's activity. It has been only comparatively recently, since the vital subject of business personnel has been brought forcibly to the front through extensive labor and wage troubles, that large business houses have come to appreciate afresh the farreaching value of some printed medium through which the expression of opinion and coöperative sentiment may be presented.

It is found upon investigation that many house organs have failed after running through a brief eareer. For example, one firm writes:

At one time we did publish a mimeographed magazine called In The Family, but this died a natural death about a year after birth.

It has been suggested by one editor of sueh a short-lived publication that the following old couplet would be an appropriate epitaph for many short-lived house organs:

If so soon I was done for,

What the hell was I begun for? 
There is a certain type of business man who has found it difficult to appreciate that anything, either in the advertising or propaganda line, which, according to his estimates of dollars and cents is nonproducing, is worthy of serious thought or coöperation of the firm. As one employer said, "charge it to overhead expense and forget it." That is not the way in which this kind of publication can be made successful. One of the first principles of success in the publication of a house organ is obtaining the enthusiastic and intelligent coöperation of the heads or directors of the firm. Without this the editorial staff will lead a wavering and staggering existence, until the project falls.

Another point of vital moment resides in relation to the policy of the magazine. Too often this is conspicuous by its absence. A first review of many house organs leads to the belief that like Topsy they have "just growed." Too many of these have been edited by the use of odds and ends of time of some busy, overworked manager, coming out like the Subway Sun, "now and then." We quote from one house:

The "House Organ" is gotten together in spare time. The writer is responsible for editing it, but has so many other things to do that the "House Organ" is becoming a sort of side issue.

There has been little or no plan for subsequent issues, covering for example a yeal of propaganda, and attention to arrangement of material has been lacking, as well as any logical sequence, or journalistic form, or order. Many of our house organs are like certain South American newspapers, with which I have been familiar, which when receiving telegraphic communications placed them on the front page in the order in which these chanced to be received. Quite often the last received and most important telegram or cablegram is the last thing down in the corner, simply because it happened to be the last message arriving.

As to policy, the following points may be considered. Before going ahead it is well for the person responsible for the magazine to have clearly in mind the main purpose. 
Given this there will be subsidiary aims whieh will require attention. James Russell Lowell once said:

If you have one room in the house where all the family meet, you may have as many hallways into it as you like, but beware of a house that is all hallways.

In order to get a number of the objective points before us we quote from a few letters received from the larger firms as to the objective policy of their house organs:

The Lamp.-The primary purpose in starting "The Lamp" was to provide a medium of information for the company's employees and stockholders. The ramifications of our business reach into many distant lands and eall for the employment of every class of labor from the lowest paid to the highest. Many of these men felt rery much out of touch with the management, for they are stationed in foreign countries and in former times, received only such meagre information as was contained in business letters. The "Lamp" attempts to tie the organization together and to extend the sphere of influence of the management over many thousand employees who have never met, and probably never will meet the men who guide the company's destinies.

Morse Dial.-Creating good will among our employees toward the company and secondarily to present to the trade some idea of the organization we have; our Masthead states that the publication is devoted to the welfare of the Employees' Association and to the interests of the company. We seek to breathe into the pages of the publication the life and spirit of the men and women employed here and in doing that we feel that we are successful in promoting the esprit de corps so essential to any organization. We preach the value of a family spirit, the fellowship of service and the relationship that exists between the employee and the employer and we try to do this in a way that will not violate the confidence of the reader.

Chemical Bulletin.-The object of our house organ is to unite the employees of the bank into a closer family, encourage coöperation among the different departments, and keep up the morale. It began as a purely internal organ and gradually grew until now we have a mailing list of 1400 and by the first of the year we hope to enlarge it to include all of our customers. 
Stewart Factory News.-Our object in publishing our house organ is to eombat internal dissatisfaction, to inspire loyalty to the firm, to inerease production, to put all employees on an equal plane and to insure coöperation and efficieney.

Western Electric News.-Our object in publishing a corporation magazine is to build up esprit de corps and to edueate by entertaining, as well as to keep before each department the activities of the other departments of the company.

Guaranty News.-The Guaranty News was published originally for the purpose of providing a medium through which the activities of the Guaranty Club might be reported. Naturally, the first editors branched off from this primary object and began to 'sell' the bank to its employees through the use of stories dealing with various departments or purpose of bank serviee. A later development was the inclusion of artieles on finaneial and business subjeets, which it was thought would appeal not only to the members of the Guaranty Club, but to officers and members of the staffs of other banks, chambers of commerce, boards of trade, and similar organizations among which eopies of the 'News' were distributed. Latterly, the tendency has been for the 'News' to develop along the lines upon which it was originally projected; that is, for some time we have been using mostly articles dealing with Guaranty Club activities. We still continue using articles eovering the bank's aetivities, but the idea now is not so mueh to sell the bank to its employees as it is to express the faet that the bank as an institution and its employees as a body and individuals, are bound together by the ties of mutual dependence, and that what is of interest to one will be of interest to the other. There is, of eourse, also the idea of representing this bank to other banks and business institutions in its most favorable aspects. We do seek to ereate good will for the Guaranty Trust Company through the Guaranty News, but I feel that its purpose is less to serve business ends of any sort than it is to have a publieation such at it seems natural and fitting for any large organization of men and women to possess.

Counter Currents.-Solely to keep the organization working together and let one half know what the other half is doing. Of course, it is a means of getting messages across better than any other method.

It seems clear that for many house organs a main object consists in the endeavor to unite or tie together the various 
elements of a large business organization. Specialization in departments has grown so rapidly that in many an American business house a man working in one department knows as little about what is going on in the department on the next floor as he knows about his neighbors on the next floor in a city apartment house. The house organ should be the means of introducing the men in one department to those in another, outlining for each something of the work, aims of the various sections, and showing how, by the giving of this knowledge, closer coöperation may be attained. The house organ is, therefore, a uniting bond, a cementing tie, and by reason of its ability to play up the accomplishments of different departments or individuals it furnishes a medium whereby pride in the organization may be engendered and esprit de corps attained.

Aixong other important objectives is that of furnishing a written record of historical events connected with the firm; the furnishing of an "employees' forum" in which the workers may express their ideas; the keeping of the firm's name before the trade; the exchange of opinion regarding new methods, new inventions and aceomplishments; selling the organization to the employees; furnishing important selling data for salesmen; "to keep up a high morale among our employees"; present informative and educational articles relative to commercial, economic and industrial subjects; giving incentive to employees toward self-training by presenting books for reading in the firm's library and furnishing courses along the line of the work of the house for reading and study.

As a result of an investigation among 100 more or less well-known house magazines of large eoncerns, we found that a large number of the editors stated that personal items seemed to be the most interesting part of the magazine to the employees. This, of course, should be considered in the making up of an internal magazine, a magazine published for a coneern having one large home office. It is not so true for those house magazines which are 
published at the home office on behalf of hundreds of thousands of employees in foreign branches scattered over the earth. In such cases Emilio Tremaleda in Bilbao, Spain, H. Sakatani in Tokyo, and Sancho Chopitea in Antofagasta would have comparatively little interest in the fact that John Jones, salesman of the home office, was engaged to Lucy Larkins, or that the wife of Bill Sykes of the trucking department had given birth to twins. On the other hand, such personal items as those connected with promotions in the ranks, new inventions of labor-saving machinery on the part of employees, certain athletic victories, appointments of new officers, opening of new offices, together with a list of arrivals and departures at the home office of members of foreign offices, all such events would naturally find their place in a comprehensive house magazine.

Apropos of this subject we quote a paragraph from a letter of Walter G. Miller, editor of The Guaranty News:

I believe employees are mostly interested in the news items reporting their own activities. For example: If some department or division has a dance or party or picnic, each member of that department or division, of course, likes to read about it afterwards, and $I$ think other departments and divisions are interested in reading about such events also. I think we are all interested in what the other man or woman is doing rather than in what an impersonal corporation is doing. I believe there is more interest in the news that John Jones has been appointed Assistant Manager of his department than there is in the fact that a new office has been opened in Kalamazoo. I believe it is the personal human touch in a house organ that makes it interest. ing.

It is difficult to lay down fixed rules regarding what should or should not be published concerning personalia in the magazine. The first requirement is a certain amount of common sense and taste on the part of the editor. If this is absent all of the fourtecn points of a League of House Organs will not solve the problem satisfactorily. 
This leads to the point of quality in a house organ.

In my judgment if the editing of a house magazine is worth while doing at all, it is worth while doing well; that is, with a sense of quality and distinction which will bring credit rather than discredit upon the house. It is perhaps the only regular message to the trade and the world, furnishing a revelation of the firm's ideas and ideals and its standards and methods. It should not only give tangibility to the firm's purposes, but it should do it in such a way as to lift rather than detract from the reputation of the house. This magazine may be the only indication certain prospective clients will see regarding the firm.

It may be well to remember that the judgment shown in the choice of jokes, the placing of a photograph, and the general make-up and appearance of a magazine, though seemingly small matters of detail in themselves, are frequently determining factors in the minds of readers as to the kind of business firm represented by the house organ.

A definite object in the minds of a good many editors of the more substantial house periodicals seems to be that of informing employees and officers of the house relative to certain products handled, as well as to certain methods of organization. This information, handled by specialists, or men who have much to do with these respective matters should be the means of clearing up the subject in a concise but comprehensive way in the minds of the readers. If the firm is exporting automobiles, the writer of the article on this subject would naturally go somewhat fully into the automobile markets in foreign lands, not forgetting an outline of the characteristics of the people who are to use these machines in other nations, as well as to show the kind of automobiles required, manner of shipment and the best sales arguments.

It will be found to be a most profitable exercise for the head of any department or specialist along any line to 
gather together his ideas and facts concerning his particular specialty and to present them clearly in an article for the house organ. This article, carefully edited and well illustrated with pictures, will be a permanent asset to the company and will be found to be in demand for a long time after it is written. For example, there are certain articles which have been contributed to our own house magazine, The Grace Log, on subjects like nitrate, cotton, tea, banking, marine insurance, merchandising, ete., which have been republished over and over again in other trade magazines and newspapers, and are in demand through our correspondence a year or more after they have been printed in our periodical. In each issue of this magazine we plan to have one such educational or trade article and sometimes two, and these, among other uses to which they are placed, are used in a reading course for our employees who are to be sent to foreign branches as managers or in other capacities. A series of such articles covering a year or more, brought together, furnish material to equip well in knowledge the young man who wishes to know not only the names of the products handled by the firm, but also to understand something of the history of these products; how they are manufactured or cultivated, how financed, shipped, marketed, etc. Much depends upon the manner of presenting this educational or trade article. It can be made as dry as a Congressional Record or enlivened and illuminated by picture and incident so that the article could be sold to one of our good popular magazines. This leads me to a brief description of one all important point, that is, "the editor."

We have already alluded to the fact that the office of editor often has been taken by a person having little or no knowledge of the writing profession, and in some cases this is only one of his many duties in connection with the firm. Sometimes we find this office is taken by the advertising manager who delegates the work mainly to a clerk. We quote in this connection a paragraph of a letter from Mr. John H. Miller, Editor of Counter Currents: 
Putting out a regular publication is no easy task, no matter how poor the thing is. But to edit a live, up-to-the minute house organ that comes anyway near being efficient is a REAL JOB.

So much depends upon the selection of the editorial director of a magazine that we are inclined to believe that unless a house has sufficient confidenee in the value of this medium to pay the salary of a man of intelligence and experience for its editorial director it would be far better not to undertake at all the publishing of a house magazine. Of course, if the desire is for only a little bulletin giving notices of personal events, athletics and social gatherings among the employees, the editorial function is not so difficult; but, even then, the house is represented by the bulletin, large or small, and if this gives the appearance of cheapness and hasty, inexperienced production, it will offset much of the value of the publication.

The editor of a house organ should himself have the capacity for writing, but more than this he should possess the ability to arouse the writing or descriptive instinct among the members of the organization who have at their fingers' end the facts of value to the eonstituency. Of course it is the editor's duty to talk over a prospective article with the man whose experience he wishes to capitalize for the magazine, giving him perhaps a suggestive outline. It is vitally important, however, that the man who knows his job or his specialty should be left free to express himself as to the outstanding characteristics, obstacles, or needs of this work, and when he has done this the editor will find ample opportunity in the careful editing of the material, in the writing of foreword and conclusion, and in general structural arrangement, for the exercise of his proper literary faculty. No editor should take it upon himself to write his whole magazine. The editor who attempts to do this is in a bad way. He will soon run out of ideas and the magazine will become a oneman affair, thereby losing general interest and missing the widespread perspective which comes from getting messages 
from every angle of the elientele. It should be the aim to have as many names of members of the organization as possible appearing in every number.

It is needless to say that among the characteristics of a successful editor for any kind of a periodical are:

First: An ability to express his own ideas clearly. Second: A sense of humor. Third: Some organization or constructive ability in the handling of his material so that the magazine may give the appearance of a well built structure rather than a hit and miss affair. Fourth: A certain congeniality which will enable him in acquaintanceship with employees to be sufficiently liked that when he asks for contributions the persons will be inclined to accept the opportunity because of personal relationship with the editor as well as by reason of their connection with the firm, or through pride of office. Fifth: It goes almost without saying that the editor or a director of publications of a large business house must make a study of the entire business in order to avoid mistakes and be able to present in his periodical a well rounded and comprehensive picture of the entire circle of the firm's activities. Sixth: The ability to write editorials timely and interpretative regarding the different subjects related to the business of his firm, including a brief digest of current events. Seventh: Industry and a willingness to exert oneself to secure proper material are absolutely necessary qualifications for an editor. As one correspondent writes -"If you want anything, go and get it!"

Furthermore, an attractive house organ can hardly be widely effective without pictures. A modern magazine without pictures is like a marriage without the bride. In this picture age the eye is becoming almost as important as the mind in gathering impressions. Photographs that are carefully captioned are frequently the only part of a magazine which is read by certain busy men. These pictures should be so thoughtfully described in the captions that if the reader gets nothing else from a look into a certain issue he will at least be able to get the running story by looking 
at the pictures. It is better usually to have fewer photographs but have them carefully selected and the cuts clear.

The cover of the magazine, of course, is a matter of considerable moment and should be decided usually from the point of view of the character of the concern and the object of the magazine. There is no doubt but that a change of cover frequently adds to the interest and every editor will realize the nccessity of giving considerable thought to the cover when it is not feasible to spend the money for making a new sketch and engraving for each number. A change in color of a stock, with a few of the interesting articles played up on the cover is often found attractive.

Maps of localities, clearly drawn, are greatly to be desired, as also are ingenious charts that are not too complicated to be impregnable. We have seen many charts and maps which leave the reader in a more perplexed state than he was before he tried to unravel their complicated detail and serpentine intersections of lines and circles. We saw a chart recently of this kind that reminded us of what a reviewer said of the book of Dr. Shedd, the old theologian. He wrote two volumes of dry-as-dust theology and when the second volume came out the reviewer, a prominent newspaper man, reviewed it as follows:

The first volume Dr. Shedd wrote, only Dr. Shedd and God understood it! In the last volume God dropped out!

A selection of pictures to really illustrate the ideas and facts brought out in the text is all-important. 'The playing up of a lot of personal photographs is more or less taboo with many of the higher class corporation magazines, but it should not be forgotten that a successful business is dependent upon men quite as much as machines or methods, and the publishing occasionally of a man's picture when he has given twenty-five years of successful service to the work, or the photograph of a victorious football team com. posed of employees, or the picture of a manager of a large plant directing his employees, or possibly a large 
group picture of officers and employees, all when properly treated, add to the impression that human leadership and trained workers form the vital life currents of any business.

It should also be noted that one of the objects of the house organ is to show the worker that his service is appreciated. There is none too much of this kind of appreciation given, as a rule, to employees in large concerns. Too often the condition exists, as was related to me recently by a senior member of a certain firm, who said:

Never expect any praise for anything you do in this firm, but if you don't get jumped on more than six times a day throughout the 365 days of the year you can take it for granted that you are doing good work.

While the house organ should not have as its chief objective the printing of flattering notices which tends often to make workers self-conscious and vainglorious, a moderate presentation of personal photographs in connection with notable achievement is usually worth while.

We have found that the appointing of regular correspondents to our magazine from other branches both at home and abroad is a most successful experiment. These appointees, after they have been carefully selected by the manager of the branch, are appointed with some formality and are made to feel that the office is a dignified and responsible one and that their communications are expected to be both regular and worth while. It is important to send a letter to each correspondent, outlining in detail the kind of material and photographs particularly desired from his section, otherwise he will be quite at sea as to what to send in, with the result that he will forward perhaps useless insignificant matter, and the tuming down of such contributions are quite likely to discourage a new correspondent.

It is our custom to send a copy of our house magazine personally to each correspondent as soon as it is issued, 
and in many cases it is accompanied by a note of appreciation when the correspondent has taken particular trouble to outline an important business situation, or with considerable effort has secured good photographs. The names of the correspondents are published in the magazine, and it is considered an honor on the part of the correspondent to represent his branch house or agency in regular communications each month.

A special annual number made up largely of photographs of different phases of the firm's activities is found to be of decided use for advertising and propaganda purposes. Photographs for this number are gathered from branches of industries all over the world, and the making of these pictures and sending them in, with careful descriptions attached to each, arouse great interest on the part of the various branches. In the case of The Grace Log four or five hundred pictures are published in this annual number. The first number was composed of pictures largely of the 150 or more branches and agencies of the firm, buildings and photographs of the staff, with certain attractive inner views of the buildings, also pictures of ships, plants, clubs and welfare organizations representing the company in different countries. The second annual number published contained photographs of the industrial, transportation and active enterprises of the Company.

It is customary to put into this annual number only photographs representing the owned enterprises, buildings, etc., of the firm. An issue of from 15,000 to 20,000 copies is found necessary to supply the widespread and exacting demands upon the Editorial Department for this number. Many departments and branches send copies of this number with personal letters to their clients with direct and encouraging business results. These special numbers are also reviewed by the daily, weekly and monthly press in different languages and different countries. We earnestly recommend this phase of the house publication's work. In this number, as in the regular monthly publication, the introduction of attractive pen and ink sketches are most 
desirable. It should be the object to make the number a delight to the eye as far as possible and to avoid a stilted and dull procession of pictures notable only by their similarity. For this special number a first-class drawing is made for the cover and $i t$ is the aim to carry the story of the work by pictures and captions rather than by articles. A two page spread of a map, showing by colored lines the various shipping and cable lines, also cities and towns where branches of the company are located printed in red, together with a list of the branches at the bottom of the map, has been found to be of real value. In fact, in addition to the reproduction of regular photographs we commend the use of sketches and drawings which add not only artistic value to the magazine, but also can be made to represent important phases of the work which are difficult to present in photographs. Quite often artistic talent may be found in the firm itself; or in other cases it is possible for the editor to secure some amateur help among his friends without undue expense. In some cases the art editor has combined with service to the magazine the post of librarian in the library which is also connected with the Editorial Department.

The distribution of the house magazine depends, of course, upon its object, whether it is published simply for the employees, for directors, for sales managers, or for purely propaganda or advertising purposes among other firms.

In the case of The Grace Log the chief object is to publish a magazine directed to the business needs of the Company, which because of its size, gives a formidable audience. In addition, however, the magazine is sent outside the circle of the organization, usually upon application, to government officials of different nations, such as ambassadors, ministers, eommercial attachés and consuls; also to the larger libraries, clubs and societies more or less closely connected with business affairs, in exchange for trade journals and house organs; to selected portions of the weekly and daily press; and to 
manufacturers and clients both at home and abroad selected with some care by the departments most closely connected in a business way.

Leading articles are republished by newspapers as well as by weekly and monthly magazines, and usually we are able to furnish pictures and sometimes cuts for such use.

A letter is also sent to branch managers suggesting the most successful ways in which the magazine may be distributed, employed to carry the message of the firm to the section in point. A certain quota is mailed as soon as possible after publishing date to each branch and agency, and there are insistent ealls received from the various branches for increased numbers of the magazine. From time to time it has been found necessary to increase the edition in order to accommodate the growing needs of the branches. It is the general rule that branches and agencies receive a sufficient number of copies so that each member or employee may have a copy. This, however, is not followed out in the case of large industrial plants, but the attempt is made to meet the requirements as far as possible of the various foreign offices.

We find it out of the question to send the magazine regularly to all of the applicants who ask for it, but when possible we strive to refer the inquirers to such organizations as the Bureau of Foreign and Domestic Commerce at Washington and to special organizations giving attention to the subjects that seem to be along the line of their needs.

The distribution at the home office is carried on by giving a copy on the night of the day of publication to each employee as he leaves the building. In the cases of certain other house magazines we find that the magazines are given out only to those who have interest enough or will take the trouble to call at the editorial office.

It is significant to note from our correspondence and our own experience with the magazines which are edited with care and reflect the spirit of the house, that every issue is in such demand that the magazine is prized and usually taken home and frequently bound in a file. It is our own 
custom to bind our house magazine, as well as our other publications, every six months in separate volumes with pasteboard covers, having these volumes always on reference in the Editorial Department. The same custom is followed by many of the larger branch offices.

It seems to be the general custom among house organs not to receive advertising and also not to make a charge for the magazine. Among the letters received from quite a wide circle of house organ editors we find only two or three who accept advertising. One correspondent, however, states:

A publication of any kind to get proper attention must have a paid-in-advance eirculation list. The paper sent gratis does not have the same value.

The consensus of opinion seems to be that the house organ, or some medium expressing the spirit and ideals of the firm, should be financed by the house itself and that the values of such a magazine are returned to the house manifold in incidental advertising, propaganda and good will engendered by such publications. Simply because the influence of the house organ is not direct and capable of being estimated in dollars and cents, is no proof that the magazine does not carry real business and monetary values for the firm.

The budget for the house organ is a varying quantity, of course, in accordance with the number of copies issued, the amount of engraving costs, and the general make-up and extent of the mailing list. We find letters in our correspondence which in several cases show an issue of 35,000 or 40,000 copics of the house magazine, with a cost of from $\$ 2000$ to $\$ 5000$ per issue in accordance with the size, quantity, quality, etc. The majority of house organs, however, find it necessary to limit their edition to a smaller number and hence, of course, to a smaller cost.

It seems to be the general experience in every case where a really worthwhile house organ or corporation magazine is published, that the real worth of this publication is soon 
recognized and the officers of the firms gradually are led to the conviction that money spent thus is quite as farreaching as any form of advertising or promotion carried on by the house.

Even a brief survey of this important field would not be complete without some allusions to the difficulties confronting house organs. Among these, as they have come to us in recent correspondence, are the following:

Western Electric News.-One of our early difficnlties was to get executives to pass material which was written in a way to appeal to the rank and file. This has been overeome praetically entirely. The contents of the magazine are now selected by the managing editor with the approval of the Board of Advisory Editors who represent all departments of the business.

The Lamp.-We are extremely fortunate in having a President who is absolutely sold on the magazine. He not only gives his heartiest coöperation to everything that is proposed, but originates many ideas to be worked up. We have no real difficulties except that of closing down on contributions in time to get our magazine out before the month for which it is dated has passed.

The Express Messenger.-Our ehief difficulties seem to be in compressing all the information and news that we would naturally gather from a nation-wide organization, into sixteen pages.

The Walworth Log.-Difficulties in gathering material would fill more volumes than are contained in the patent office. Our ehief and only encouragement is 'your last number was not quite as good as the previous one.'

Stewart Factory News.-One of the ehief difficulties which I have to contend with is the failure of our dealers and employees to contribute. We send out appeal after appeal, both in the factory and around to our dealers, for articles, tips and suggestions of any kind, but as time goes on we find that the help and aid we get is about as 'scarce as hen's teeth.' However, if we fail to get out an issue on time the result is that our employees and dealers never let us hear the last of it, from which fact it is evident that they are keen about house organs, but are not long in contributing to their make-up.

Westinghouse Electric News.-Many employees who have left our company have requested continuation of 'The News.' We 
see it on trains and street cars, being read and taken home. Our telephone is busy when it is late. Are we discouraged? No!

The Headlight.-Our main difficulty is in securing copy that will interest all classes of employees. You probably know our plants are scattered about the country and while personal items are very much appreciated by the employees at one particular plant the same people are not known at the other plants. It is, therefore, necessary to try to secure copy which will be read by all employees at all plants. Our chief encouragement lies in the fact that if we are a bit late with our issue the inquiries are numerous as to whether it has been stopped and the men appear very anxious to get it at the time it is handed out with the pay envelopes. The magazine is not thrown away but is taken home and read.

U. F. Co. News.-The greatest difficulty I have encountered is satisfying the majority of cmployees. To illustrate: a number of them will send in various items which are of no interest to anyone other than themselves, and upon the failure of these articles to appear in the magazine, dissatisfaction arises, and the same result occurs with other parties when such articles are published. The best way out, which I have found, is not to publish them.

General Chemical Bulletin.-Our chief difficulties are with the printers. Our chief encouragement is that while our publication is given out to employees only on request, nearly eighty per cent of them eall for it personally.

The last year has been a particularly trying one for all kinds of publishers and we find that a good number of house organs have been discontinued because of depression in business, the high cost of paper, engraving and printers' troubles. In some cases house organs usually published in large cities are sent out to printing firms in smaller towns, thereby saving considerable expense.

Although the difficulties covered in the above quotations are real ones and are in line with the obstacles confronting editors of this class of publication generally, none of them are so formidable as not to be ovcrcome by editors who are really qualified for their important posts. As Napoleon once said, "Difficulties are things to be overcome!" and it is well for every editor to remember that he is not the only 
man who is confronted with "insurmountable difficulties." In some cases it is necessary first of all for the editor to make his magazine so good and so indispensable to the business that he can sell it to the management. Many members of old, conservative business firms, who have taken an indifferent or critical attitude to the housc organ at its inception, have been won over completely after seeing the interest displayed in the publication on the part of employees, and after realizing the possibility of the house organ among the salesmen or clients of the firm.

We come back then to the point which we consider more vital than any other in the whole subject, that is, the presence of an editorial leader who possesses vision, tact, cer. tain literary ability and a dogged determination to make his publication useful to the firm. A business or corporation is more or less impersonal. A house organ must personalize and make tangible the ideas and methods of the company. This art of bringing the organization to a clear focus, this visualization of the company's ideas and ideals, is brought about largely by the ability and ingenuity of the editorial direction. If this is competent both the spirit and the method of the business involved will be so breathed through the magazine that it will truly represent the House. 


\section{CHAPTER XIV}

\section{NEWSPAPERS AND PERIODICALS AS FOREIGN TRADE BUILDERS}

The daily press and the periodical, both at home and abroad, are among the most potent means of extending foreign commerce. This propaganda has failed in many instances through lack of knowledge as to how and where to place advertising material.

For the benefit of those who would learn the character of the press as a means of advertising produets, partieularly in South America, I quote some remarks made in my former book The Brazilians and Their Country:

There is no doubt but that the work of the press in the United States has been instrumental in recent years in arousing a new and widespread interest in the South American Republies. One American consul informed mo that in the years 1914-1915, when South America became particularly prominent in our newspaper world, he received, largely from business men in the United States, ten thousand two hundred pices of mail. There were floods of letters about every conceivable subject germane to the securing of South American business, and a deluge of eatalogues, which for the most part, being printed only in English, were quite useless to prospective Latin Ameriean customers.

It is quite evident from a study of this particular subject that the American press as a whole has failed to include in its information concerning South Ameriea many faets of prime importance, and in some cases it has so highly 
colored other facts as to give a wrong impression. For example, one will be told by the most levelheaded business men in South America that while there is a real opportunity for large capital, and for those firms to enter the arena of trade which can meditate enterprises like the building of railroads, the opening of mines, the construction of large docks or the starting of-steamship lines, the opportunity for the man with little capital and with no branch house in South America is more greatly limited. The press would do well to emphasize the fact that the American business man who goes down there is at once confronted with the Spaniard, the German, the Englishman, the Italian and the Portuguese, who are at home in the language of the people; who in many cases have inherited generations of experience in selling goods to the South Americans, and who also are probably unsurpassed as intelligent traders for these countries. To meet such competition, the American business man must "go after" his foreign markets.

The truth about South America would include also the fact that the sending of young, inexperienced men down there to cope with these hardened veterans in trade has proved disastrous to many a firm; a further truth which may not be too often repeated is that the South American is not predisposed to trade with North Americans, and he is quite as independent relative to this matter as are our own manufacturers.

It is quite evident to an unprejudiced observer that South American business is not a prize to be gained at a bound; it must be necessarily an evolution, for the South American does nothing in trade lines in a hurry. His conservatisms and traditions hold him as in a vise. It will take every ounce of ingenuity and perseverance which the North American business man possesses to gain an equal footing in these republics with England, for example, and if he accomplishes this in the next twenty years, it will be by dint of the keenest exertion and a far more profound study of the South American people and their country than he has yet deigned to give them. This at least is the 
common testimony which one who mixes with all sorts of business men in these countries will receive to-day.

Another contribution which the press of the United States may make in the interests of mutual relationships would be a more careful study of South American journalism, especially with the view of publishing material in these papers which the South Americans would gladly read, and which would enable them in turn to get acquainted with the United States.

While I was in Lima, Peru, the leading newspaper was publishing a series of articles upon conditions in North America which were making a decided impression in that city. The articles were a revelation to many who had as little conception of what the United States was like as that possessed by many of our people regarding the Land of Pizarro. The editors of many newspapers have told me that they would be glad to form connections with newspapers in the United States for such articles, and they also have said that they realize that their papers give far more space to European matters and to their sister Republics than to their Northern neighbors.

In writing these articles it should be remembered that the Latin American has a different idea of the presentation of his material than does our press. It would seem to Northerners to be lacking in system, and frequently as dull as a Census report. One of the largest newspapers in Spanish America makes a boast that it has never, during its entire eighty years of history, published a picture. Glaring headlines also are conspicuous by their absence in the best journals, while long communications on serious subjects are given considerable space, sometimes even a whole page. The Jornal do Commercio, for example, while I was in Brazil, gave eleven columns of space to the account of an event of the Academy of Letters in Rio de Janeiro, while it is not uncommon in South American journalism to find several pages given to the verbatim description of a debate in Congress.

It is said that the South American reads only his news- 
paper, and also that the newspapers are responsible for the molding of sentiment in a way far beyond that known in other parts of the world. One editor told me that he nearly lost his life because the people claimed that his paper was responsible for starting the greatest revolution which his country had ever experienced. One oniy needs to go to the clubs to see the crowds of men surrounding the newspaper tables, and then visit the libraries of these institutions (which is the one place in the building where you can be perfectly sure of being quite alone), in order to recognize the influence of the newspaper among the Latin American gentry.

Another service which might well be entered upon as a policy by certain of our newspapers and publishers who are interested in Pan-Americanism, would be to start a campaign for travelers to South America. In the last analysis the only way to understand a country is to go and see it, and the study of successful American business south of the Rio Grande proves beyond a shadow of a doubt that it has been a farsighted plan for manufacturers themselves to visit these countries in person before spending their money upon projects that would have been found at once by them to have been impracticable had they previously visited the country. Some day, not far off, South America is to be the traveler's paradise. In Cuzco and along the whole stretch of the Cordilleras one will find conditions as primitive as exist in any part of the Orient; in Southern Chile there is a beauty of mountain and sea which rivals anything to be seen in the Alps; the haciendos of Argentina, the coffee plantations of Brazil and the rubber regions of the Amazon make unforgettable impressions upon the traveler; while the American will travel the world over through all his years without finding such a dream city of enchantment as is Rio de Janeiro, lodged in an amphitheater of hills, and looking down through tropical sunshine upon its peerless bay.

Furthermore, if the press of the United States would get on with the South American, it should realize that adverse 
criticism without presenting the more promising traits of the country and the people, is fatal to success. One is dealing with a different temperament there, and with natures as sensitive to dispraise as are the Orientals. They are willing to have their weaknesses pointed out providing a man is simpático in the manner of his presentation. There is not, in this part of the world, the custom common in the United States and England of hitting every head that comes to the surface. When they do hit them, it is done with politeness.

A writer on South America said recently in his preface that enough flattering remarks had been made concerning these people, and it was his intention in his book virtually to show them up with all their weaknesses and faults. It is needless to say that such an announcement doomed the book in the minds of many of these intelligent and keenly sensitive people. As a matter of fact, the press of the United States can find remarkable material for the interest of its readers in the old settlements of this hemisphere which are only just learning to become Republics. The history of Simon Bolivar the "Liberator," of San Martin, of Pizarro in Peru, of Valdivia in Chile, or of Cortes in Mexico, is as fascinating in adventure as historical romance; while Paraguay with its Dictator Lopez and its war in 1860 that practically eliminated every man in Paraguay, or the picturesque colonial and imperial history of Brazil, the only large American Republic which has possessed an Emperor, read like the story of "a thousandand-one-nights."

Foreign trade is a far bigger thing than shopkeeping, or consular statisties. It is based upon national characteristics, and its ramifications are as wide as history and as vital as personality. No one travels abroad with seeing eyes who does not recognize the provincialism in many sections of our press in the United States. In this era of world expansion, when the nations of the earth are drawing together, in order to be able to live separately, the newspaper that limits itself to the locality where it happens to 
be published is destined to a career of superficial and shortsighted opinion.

The press of the United States needs editors with telescopes as well as microscopes. The newspaper is the mirror held up to human nature, and human nature is not bounded by any such narrow limits as north or south, or east or west; it is a world thing, and it includes as Kipling would say, every country "where two strong men stand face to face."

There are signs apparent that the press of North America is beginning to realize this, and it is one of the most encouraging symptoms on the horizon, not only as far as relationships with South America are concerned, but also as regards the intelligent part that the United States may be called upon to assume in the fraternal federation of the world.

There is no doubt but that advertising in newspapers and periodicals, both at home and abroad, would be doubled in value if such publications possessed the right point of view in relation to foreign lands, and carried in their news columns and editorials the spirit of coöperative understanding so necessary to foreign trade relationships.

As to suggestions concerning advertising in periodicals for the purpose of fostering foreign commerce, a few hints may be made.

1. The advertising campaign must be reasonably continuous. Advertising in foreign periodicals is subject to the same laws as advertising at home, in many respects, a definite policy being required.

2. The advertisement should be written in the native tongue and not translated from another language, especially from English where the idioms are often difficult of interpretation. It must be remembered that "selling" Spanish or "selling" Japanese is quite a different thing from "correct" Spanish or "correct" Japanese. The right appeal can usually be obtained only by having the advertisement written by a native of the country where goods are to be sold or by a competent advertising agent.

3. Each country should be handled by itself. Rarely will the 
same advertisement copy meet the needs of a number of different nations. It must be remembered that there are eighty-seven countries in the world and no two of them are alike.

4. The choice of the media for advertising abroad should be given as great care and consideration as that given to domestic campaigns to reach the American market.

5. Make sure that you are not advertising an article in a foreign country where it will be impossible or almost impossible to sell it. For example, a certain American advertiser spent a large amount of money attempting to sell the English trade a syrup for pancakes, discovering too late that pancakes were not on the English bill of fare. Likewise, an American seller would not try to dispose of breakfast cereal in France unless he first established a comprehensive educational campaign. In some countries the servant classes are so illiterate that advertising campaigns for such articles as laundry soap or washing machines would not have an immediate effect. Knowledge of the country is in every case essential. 'Study the market' is the slogan for foreign trade advertising. A certain advertiser persistently advertised in Japan his lawn mower, using follow-up letters, etc., not realizing that there is hardly a lawn to be found in the 'Sunrise Kingdom.' An American went down to Argentina to try to revolutionize the Argentinos by advertising a brand of chewing gum. Nobody knew what the words meant and the Argentinos couldn't pronounce the words 'chewing gum.' After considerable advertising in street cars, etc., the Argentinos were led to believe that chewing gum was a 'sure cure for smoking,' at which announcement the Argentino would not touch the article, thinking it might make him want to stop smoking cigarettes.

The following advice given by a prominent manager of a foreign trade department of advertising is worthy of notice:

Advertising is not 'the royal road to success' in the general acceptance of that sentiment. Advertising alone will not sell goods. The expenditure of a certain fixed sum of money in and of itself is no guarantee of large sales or repeat orders. There is no magic wand of any kind which the American manufacturers can wave over the Latin American or any other foreign 
field and obtain immediate success as the result. Instead, you will find that the same bases which have been employed in building up domestic trade are equally necessary in establishing foreign relations with such allowances as are ealled for by differences in temperament, race and climatic conditions. No merchant or manufacturer should seriously consider entering any foreign field without first having made a study of the country, its people and the things they buy.

As to definite kinds of periodicals to use for foreign trade advertising the following suggestions may be of use: Saturday Evening Post, Literary Digest, New York Times, System, The Christian Science Monitor and the New York Herald, all of which papers and periodicals have been read by the writer in foreign homes and many clubs of the chief cities of the Orient, Europe, Africa and Latin America. The advertising in these widely read American publications is quite likely to be noticed by business firms in different parts of the world and this has been a very real means of starting first inquiries concerning American products.

One of the first mediums to be considered is that of export trade papers which are becoming important international trade media. These export publications are looked upon by many business men abroad as catalogues of American products in merchandise and have been one of the greatest single factors of private enterprise in bringing together more closely in the commercial interests, not only the two Americas, but, our country and more distant lands.

In sclecting the magazines or periodicals generally for advertising in foreign lands it is necessary to have local knowledge concerning such subjects as the conditions of the market, population, its buying power and the kind of publications which are most naturally adaptable to the traits and tastes of the people one wishes to impress.

In Argentina, for example, there is probably a greater variety of good publications than in any other one Latin American country. It must be remembered, here as in 
other republics to the south of the United States, that newspapers take the place very largely of magazines, and there are many influential and well-edited newspapers throughout Latin America which carry great authority with the people. In Buenos Aires the prominent dailies like La Prensa, La Nación, and La Razon, carry a large amount of local advertising while the first two mentioned contain many American advertisements. The high-class Argentine weekly, Cara $y$ Caretas has a large circulation up and down the coast as well as in the interior of the country, and in a recent issue carried 50 pages of advertising, 91/2 pages representing products of 15 American advertisers. There is also the artistic monthly called Plus Ultra, reaching the best classes of society and in its general make-up compares artistically with magazines published in the United States.

In the Brazilian Republic there are important dailies such as Journal do Commercio, Correio de Manha, O Imparcial, together with the illustrated and popular weeklies Fon Fon, $O$ Malho, etc., all of which circulate widely through the whole Republic. The Brazilian newspapers carry many literary articles which would naturally appear in the United States in our better magazines. The newspapers here as in Argentina are institutions of the country and are regarded with high respect.

Among the important publications in Chile are the dailies El Mercurio of Santiago, and El Sur of Concepcion. There is also the illustrated weekly review $\mathrm{Zig} Z \mathrm{Zag}$, which circulates widely on the West Coast.

In going up the coast to Peru the dailies assume even a more important position and carry the chief advertising messages. Among the reliable newspapers are El Commercio, of Lima, and La Prensa, of the same city, which have a very large and important following in both business and social circles.

The West Coast Leader, a paper published in English at Lima, Peru, circulates quite widely along the West Coast, and is a well-edited and worth-while publication. The Review of The River Plate, a British weekly paper 
published for the most part in English in Buenos Aires, carries in addition to British copy considerable advertising of American firms.

World markets, however, cannot be exhausted without a more or less wide knowledge on the part of some one connected with the firm relative to media in all the large foreign countries. (We are indebted for certain of this information to Howard G. Winne, manager, Johnston Overseas Service.)

In Australasia the following dailies have been suggested as worthy media for attention: Melbourne Herald, Melbourne Age, Sydney Morning Herald, Brisbane Courier, Wellington Post, The Press of Christchurch, N. Z., and other worthy dailies throughout the commonwealths. In the class of important weeklies of Australasia may be named the Sydney Bulletin, The Australasian, The Auchland Weekly News, and The Weekly Press, Christchureh, N. Z., etc. Among the trade papers of this section we would suggest such reviews as Australasian Hardware and Machinery, Chemist and Druggist of Australasia, Chemical Engineering and Mining Review, Australasian Leather Trades Revicw and substantial motor trade papers.

In South Africa the prominent dailies to be mentioned which have a wide influence are the following: Cape Argus of Cape Town, with its valued weekly edition, The Week End Cape Argus, the Eastern Province Herald of Port Elizabeth, and The Star of Johannesburg. The Sunday Times of Johannesburg wields a powerful influenee and is recognized as the most important Sunday issue of that district.

Trade papers which will be found satisfactory in South Africa and which are read by the chief commereial and industrial people are: Industrial South Africa, South Africa Mining Journal, Motoring in South Africa, South African Motorist and Farmers' Weekly.

In the Far East both English and native periodicals should be noted, since the English dailies and trade reviews are required to reach important traders and foreign buyers 
despite the fact that they are not generally read by the native population.

The Far East and Eastern Commerce published in Japan, carry a message in English and Industrial Japan presents the story of selling in the language of the country.

In China we have Millard's Review, Industrial China and Far Eastern Review all of which make a substantial contribution to the trade press, while dailies in the English language have been proven good media, and among these are: The Pekin Daily News, The China Press, North China Daily News and the South China Morning Post. In China, as in Japan, firms having local branch houses situated in the larger cities would naturally depend upon their local managers to select such periodicals in the native language as would be the most useful to the particular product which they wish to advertise.

In India there are dailies and weeklies well edited, such as the Times of India, Bombay; The Statesman, Calcutta; Capital, Calcutta; Madras Mail, Madras, and trade papers of the character of the Indian Textile Journal.

It may be further noted that throughout the English rcading colonies of Great Britain one finds the Illustrated London News, The Sphere, The Sketch and the Graphic. These papers are very popular and should not be overlooked among advertisers who wish to reach by pictures as well as by printed word the constituencies of such countries as India, Ceylon, Burma, South China, Egypt and South Africa.

French publications are important for study by manufacturers, since France has become such a large buyer of American speciaities of all kinds. The trade and technical reviews are receiving increasingly large support on the part of American advertisers. Among the leading dailies in France may be mentioned Le Petit Parisien, Le Matin, Le Temps, Le Journal and L'Iniransigeant. Among the technical and trade joumals are such reviews as $L$ 'Usine, L'Outillage, Sciences et Armées. In one of the comparatrvely recent issues of the $L$ 'Usine there were 105 pages 
of advertising with five whole pages given up to the advertising of 13 American manufacturers. In France there is also a large and good selection of engineering papers, hardware and machinery reviews, factory and plant publications and papers on lumber and leather trades, in all of which the rates are much lower than they are in the United States.

In Scandinavia there is a well developed press with dailies and weeklies reaching the commereial and industrial interests. Among those of note may be mentioned Affarsvarlden, Electroteknisk Tidskrift, Ingenir, etc., corresponding to our American issues of Manufacturers' Record, Electrical World, American Machinist and papers of a similar character.

If the appeal has a more general character, and dailies are required, the highly regarded Aftenposten, Christiania; Politiken and Borsen, Copenhagen; and Dagens Nyheter, Stockholm, are available.

The American manufacturer who is really in earnest about foreign trade will find that a study of the large variety of the media for presenting his products in foreign lands will furnish him not only with valuable money returns when properly studied, but also will stimulate his mind and imagination to a new and wide interest in the various nations, which are being bound to us to-day more closely than ever before in vital commercial union. 


\section{CHAPTER XV}

\section{DIPLOMATIC AND CONSULAR SERVICE}

And statesmen at her council met, Who knew the seasons, when to take Occasion by the hand, and make The bounds of freedom wider yet.

-Tennyson.

In these days when the eyes of the American exporter and manufacturer are lifted to distant horizons, the activities of the American Consul and diplomatic officers in general in foreign lands become increasingly important. Among the men who are serving the United States abroad there are few who have the opportunity of wielding greater power or influence on behalf of their country than the diplomatic and consular representatives. It has been my privilege to know many of these men in different countries, and on the whole I have come to respect them highly, both for their ideals and the manner in which they are striving to attain them, frequently under arduous and difficult cireumstances.

The functions of ambassadors and ministers of the diplomatie corps are practically identical save that an ambassador is the representative of the President, with power to aet, while the minister is the agent of the President, who aets only on instruetions. Ministers hold the position of head official of legations abroad in those countries which are considered in the group of lesser powers, while official title of ambassador is conferred upon the ranking diplomatists to the greater powers, such as England, France, Italy, Japan, ete. There are eleven countries of major importance to which the United States sends ambassadors and the government is represented by about thirty ministers in foreign countries. Ambassadors receive $\$ 17,500$ for their services and ministers about $\$ 10,000$ per year. 
While the greater part of the effort and time of our diplomatic representatives is directed toward preserving amicable political relationships between the country wherein they are established and the United States, their influence has a salutary effect upon our foreign commerce in proportion to their knowledge, wisdom and foresight. It is part of their duty to negotiate treaties with forcign powers tending to assure equal opportunity in promoting exchanges of commodities unhampered by unfair practices or unjust diserimination. They are watchful to anticipate the more important and far-reaching political measures and policies of foreign countries which draw a discriminatory line between the United States and other nationals in relation to the just and common rights of both as affects commerce, as well as to convince the foreign government of the inadvisability of such action.

Recently the Chamber of Deputies of Holland passed a law practically barring American business interests from participating in the development of the rich Djambi oil fields in the island of Sumatra of the Dutch East Indies. The law granted a concession virtually amounting to monopoly of business interests to other nations with whom we should enjoy equal opportunities and advantages in this development work. The Department of State, through our minister to Holland, protested the action as unjust discrimination and it is the task of our diplomatic official to work toward a solution of the difficulty.

After a world upheaval such as has been brought about by the war a series of new conditions demand a readjustment of existing treaties which often are found ineffective due to the changed situation. It becomes the duty of our ambassadors and ministers to effect such changes in policy as is deemed advisable to secure the greatest facility and justice in our trade relationships.

It is also in the scope of the diplomatic official's duty to negotiate and effect the terms under which foreign loans shall be consummated. This was a specially vital activity during the war time, when the allied governments borrowed 
from the United States some $\$ 13,000,000,000$ with which to help finance their war operations. American industry and foreign commerce were greatly quickened and stimulated as a result since these loans made possible vast purchases by Great Britain, France, Belgium and Italy in America, of materials that were desperately needed.

Another important duty of our ministers abroad is to arrange for the purchase of islands or other foreign government lands or possessions in the acquisition of which there is particular value to the United States. The treaty which transferred the Virgin Islands in the West Indies from the sovereignty of Denmark to our jurisdiction is an important example. The port of St. Thomas is a strategic coaling station for our merchant marine and the commerce with these islands has been greatly enhanced by reason of the purchase, which was negotiated by our former minister to Denmark, Dr. Maurice Francis Egan.

The work of the American consul cannot be considered entirely by itself; it is intimately associated and reciprocally related to the attitude and activity of the American exporter and merchant.

Edward J. Norton, one of our consular agents having wide experience in both the Far East and South America, writes as follows:

The commereial work of the American Consular Service is directed towards helping the exporter help himself to foreign trade. The consuls are expected to inform the exporter what products sell or might sell in the world's market; about the competition that exists, and how to meet it; suggest a means of getting into these markets; how to handle orders and how to hold trade. In other words, the function of the consul is to analyze the foreign market.

Our Consular Service is now so organized and developed that the exporter at home wishing to plan a foreign market selling campaign, and facing possible purchasers widely distributed geographically and with equally wide extremes of buying power and needs, can-by going about it in the right way-get nearly all the information he requires about trade opportunities through the consul. 
However, the assistance rendered by the Consular Service to the exporter is generally well known. On the other hand, very little has been said about the assistance the exporter can render to the consul.

In this connection Mr. Norton points out that a consul would be greatly aided if the American exporter would write him definitely concerning certain products which he would like to have him investigate as to markets in his particular section. He states, with good reason, that many of the requests which come to consuls are so indefinite and vague that the man of the Consular Service is at sea to know the particular thing about which the American manufacturer wishes to be informed. He also states that most of the Consulates are glad to keep a file of the catalogues and price-lists of American manufacturers and exporters for the information of people wishing to do business with American firms. By sending these catalogues directly to the consul, the manufacturer not only serves himself, but expedites business, making it possible for the prospective buyer in foreign lands to secure his information through the guidance of a consul as a representative of American business.

The work of the American consul is not accurately understood even by many exporters who would be supposed to have a knowledge of the services of these important officers.

The ineffectiveness of the consul has not been due entirely to unwise appointments although certain of the consular appointments in the past have not been wise or satisfactory. It is easy to criticize an individual officially, especially if one does not have full knowledge of the conception of his office. It is natural that people should be more ready to seek any faults concerning our consular service than that they should be ready with praise for these men, who in many cases are exiles for life from their native land, and are rendering most devoted service to the country to which they are attached.

The main business of the American consul is to develop and maintain commercial and trade relations between 
Americans at home and the business people of foreign countries. He owes a responsibility to the State Department involving frequent and detailed reports. He must keep an account of shipping and port statistics, registration of American citizens, passports to be viséd, together with other political and statistical reports. The consul also has celtain jurisdictional work, settling the estates of persons dying abroad, while there arises often certain intercessory services on behalf of the American colony in countries where there are capitulations or extra-territorial rights.

The Treasury Department also demands certain duties from the consul such as transfer of all the United States bonds abroad, income tax business, also demographic statisties which must be secured and sent every week to the Department at Washington, together with bills of health for ships.

The Department of Commerce requires also from the consul the following duties:

1. To legalize all transfer of shipping.

2. To survey all protested cargo and protested shipments of merchandise and damaged ships.

3. To attend to the discharge and enrollment of every American seaman in his port.

4. To act as intermediary between ships' captains and port authorities.

5. To send American sailors to hospitals when it is required, and also to see to their burial and to the settlement of their estates.

6. To write regular commercial reports.

7. To settle all disputes between masters and mariners.

No little part of the excellent service rendered by the Department of Commerce to manufacturers and customers in their various reports is due to the work of the American consul in gathering statistical knowledge and data.

The consul is also connected with the Department of Navy as the representative of the Bureau of Hydrography and he is expected to keep in line with the changes of 
lighthouses, being held responsible, in part at least, for any wrecks that occur by reason of changes in signals, lights, ete. The receiving of warships in his port with proper ceremony is also part of the consul's duty, as well as purchasing of eargo and oil for these ships if it is so desired.

Reports are sent to the Department of Agriculture relative to crops and the consul acts as agent for the sending of grain and fruit seeds. He is also the deputy officer of eustoms and must legalize invoices at the point of origin, unless such invoices are less than $\$ 100$. He is responsible for itemizing invoices from which import statistics of the United States are made up, and is thus required to know the wholesale prices and hold a check upon any articles undervalued.

As agent of the Dead Letter Office of the United States the consul holds responsibility to the Post Office Department and he also receives mail of American citizens at the consular office, forwarding it when neessary. Secret service men of the Army and Navy are aided by the consul as well as traveling officers of the Government, not to speak of the varied duties which he performs for tourists. His correspondence is considerable and he represents the courts of the United States for the Department of Justice, having notarial responsibility and being a Commissioner of Deeds. Commercial treaties of course must be known by him, and in fact the consular office is an all-around clearing house for nearly every branch of the home government.

For all these duties the consular office is still poorly paid, since he is obliged to be under an expense abroad greater than would be the case if he were living at home. Rarely do consuls save money and if his appointment is lost he finds it difficult to return to the United States and procure a position along the line of his most effective qualifications. There has been some talk of consular pensions which would be a step in the right direction. It eannot be too strongly urged that a civil service plan for consular posts should be adhered to in order that the consul 
and his subordinates may feel that good work will be appreciated and rewarded by permanent consular occupation. Once a man has entered this service, if he is in any wise a student of conditions and peoples, he finds the work both fascinating and vitally important. We know many men who are remaining in this service at financial sacrifice, simply because the work is both congenial and alluring, as a means of serving their country in a time of great opportunity.

The war has caused such a widespread upheaval, not only in political but also in commercial affairs throughout the world, that reconstruction is necessary in the diplomatic and consular services as in virtually all other departments of our national life.

While the business man in many instances in the past has become somewhat discouraged as regards the possibility of securing in various foreign countries, uniformly at least, Government representatives and officials, who by training and personality are capable of truly representing the country and assisting in trade, it would seem in this new era of industrial and intemational relationships that politics should be adjourned more and more and the economic commercial progress of the United States reëmphasized in the appointment of our national representatives abroad. These representatives should be charged with the high duty of real leadership on behalf of their country in the great competitive industrial contests for America's rightful commerce and economic expansion.

The great gulf between the diplomatic and consular bodies should be bridged as far as possible, and the men appointed directly for trade responsibility should be given a new and dignified status in the countries to which they are attached. Doubtless, it would be impossible or unwise to follow the law on the statute books in Italy calling for an interchange of officers between consular and diplomatic departments; but for the sake of the vital necessity for furthering national economics abroad, at a time when every functionary should be keenly alert in loyalty to the great 
foreign trade expansion of the United States, thought and careful planning should be given to team play between our foreign representatives. These men have tremendous possibilities in their hands; the diplomat, the consul, the commercial attaché, the trade commissioner, should be selected from our most successful and experienced men wherever possible, and they should not only be given salaries adequate to their talents and tasks, but they should be relieved of mere office routine duties in order that they may have time to meet the new responsibilities involved in racial understanding and commercial interpretation.

It required the war and the extensive system of German propaganda to awaken our country, as well as the other Allied nations, to the need of publicity as a means of conserving political and economic life. The conviction is growing that publicity is not only a necessity to save democratic institutions, but it is a legitimate instrument of trade to be used in a world-wide manner. If Great Britain found the necessity of appointing a minister of propaganda in war time such as Lord Northcliffe, France such a man as Andrew Tardieu, and Italy a like representative for promoting national and economic requirements, it should be a signal for the United States to consider the permanent use for publicity purposes of diplomatic representatives of high caliber who would travel through various countries, not on social but industrial and propaganda missions. We have had quite enough of social junkets, commissions to South America and other lands, whose members have spent their time in entertainments and receptions arranged by the lands visited, through sometimes an overdue sense of courteous hospitality. The present need calls for men accredited by our Govermment or reputable commercial bodies of high standing in finance, insurance, advcrtising, manufacturing and merchandise, who will be more or less permanently abroad, and closely in touch with our home markets to suggest directly and practically what should be done to foster an expanding American commerce with all the world. 
The time has passed when Americans look despairingly upon the printed page as a means of publicity in foreign activities. Our national competitors are quite ready to catch up our weaknesses and our failures in labor or in political matters and play them up out of all proportion in order to influence adversely other nationals against our commerce. It is encouraging to note that with such countries as South America particularly, new press agencies are being formed by which the people of these southern republies are realizing more and more the true proportion of affairs in our national and commereial life. But systematic and dignified publicity-diplomatic coöperation between our agents abroad-requires leadership of a high order. It should not be left to chance or to half-informed journalists or scheming politicians. There is a new requirement in this field for representatives of trade as well as of statecraft whose knowledge will measure to their gentlemanhood and their efficiency. Let us keep our second-rate men at home. The foreign field requires men best representative of brains and experience. We would suggest a new course in every college curriculum of our land with a eaption over the door:

How to Prepare Diplomats and Consuls for American Foreign Trade! 


\section{CHAPTER XVI}

\section{MUTUAL MARKETS BETWEEN THE UNITED STATES AND JAPAN}

The character of Japanese imports into the United States indicates that American manufacturers need not fear destructive competition from Japan, while exports from the United States to Japan are of sufficient importance to American producers to render desirable the maintenance of satisfactory mutual trade relations between the two countries.-Commerce Monthly.

From the time when Japan achieved her military victory over Russia, real Japanese industry and progress took on a new meaning not only for the Orient but for the entire world. We chanced to be in the East shortly after Japan's war with Russia closed, and it was impressive to see the way in which this victory of an Oriental over a European nation thrilled the entire Eastern world. The modernization of Japan continued steadily up to the time of the European war which marked a new epoch in her progress and outspreading power. Not only her military but her shipping and commercial interests were greatly advanced by reason of the exigencies of the great war and there is no doubt that her trade ambitions relative to Siberia and China have been vastly increased recently.

It has become more and more a realized fact that Japan is dependent upon foreign trade for the maintenance of her modern national and economic life. Her area (exclusive of Korea and Formosa) is about one-half the area of that part of the United States north of the Ohio and the Potomac rivers and east of the Mississippi, while her popu- 
lation at the close of 1918 was $57,150,000$ or about onetenth greater than the American area cited. The resources of Japanese soil are not adequate for the maintenance of such a large population and the importation of raw materials for reëxport in manufactured form is absolutely essential in order to give employment to this closely packed population. In Japan only 16 per cent of the land is arable and there is only about $1 / 4$ of an acre to a person for cultivation. Realizing this Japan has devoted particular attention to her export and carrying trade, to her manufactures and her industries, with the result that in almost every nation of the world to-day Japanese business men and merchants may be found competing with no mean success with the western nations for the expanding business of such trade countries as South America, China, South Africa and the East Indies.

Among the problems which the Sunrise Kingdom has before her at present is that of bringing unity between the militaristic and more democratic sentiment of the country. Undoubtedly the influence of Germany from a military point of view has been great in Japan and this party evidently is placing certain obstacles in the way of peaceful trade with the rest of the world. Thomas W. Lamont, of J. P. Morgan \& Company, who visited the Far East to confer with representative bankers of Great Britain, France and Japan, to form in that section a consortium for the economic development of China particularly, spoke on his return before the American Manufacturers' Export Association at the Hotel Pennsylvania regarding Japan and the United States:

Japan is commercially to-day under the handicap of the so-called military party, which of recent years has been so strong as almost to constitute an actual super-government. There are two schools of thought in Japan, and the cleavage is a deep one. One believes, as we do here in America, that a nation's development, to be sound and sure, must be along lines of peaceful trade and the cultivation of good will. The other party in Japan, the militarists, have a different philosophy. They believe 


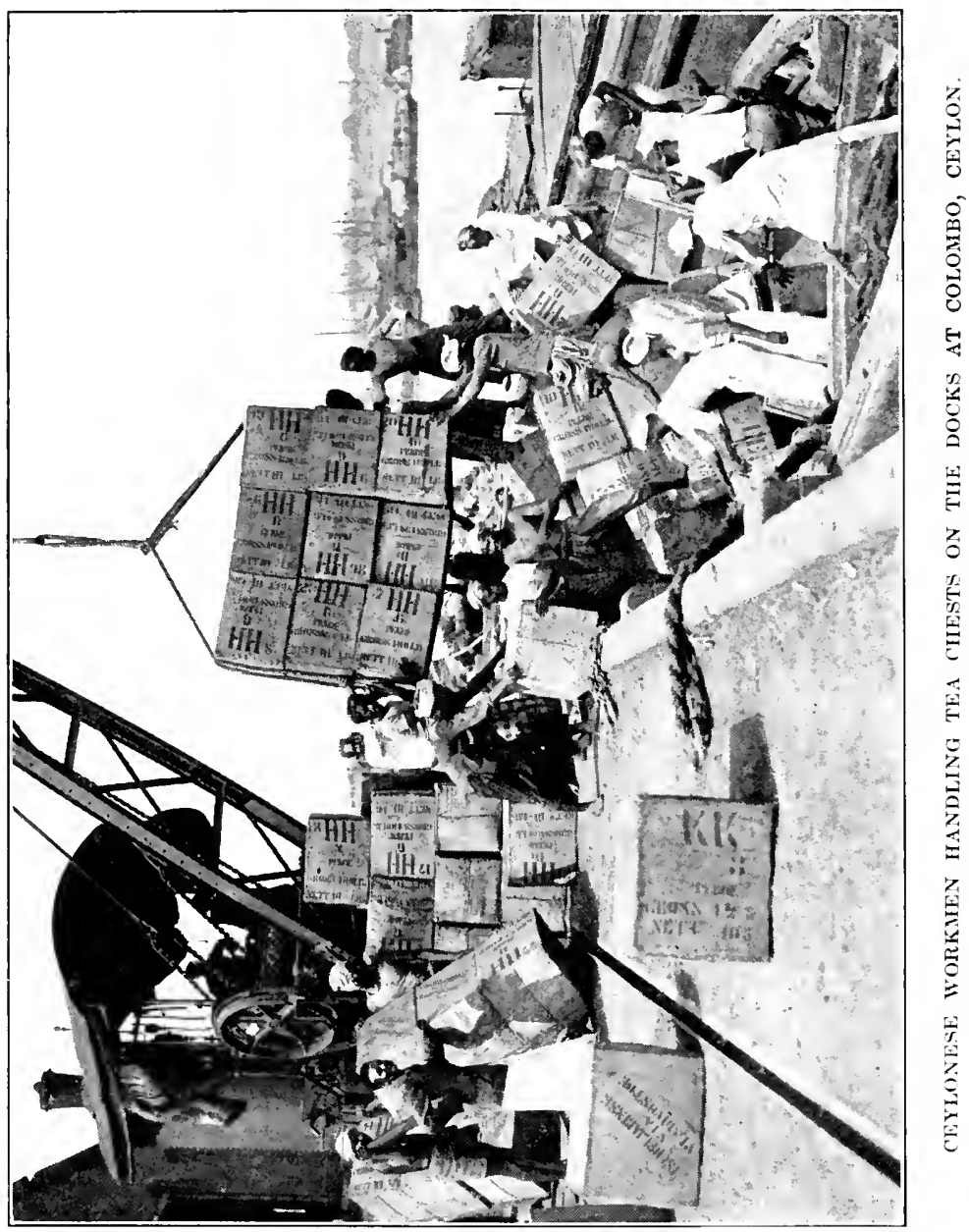




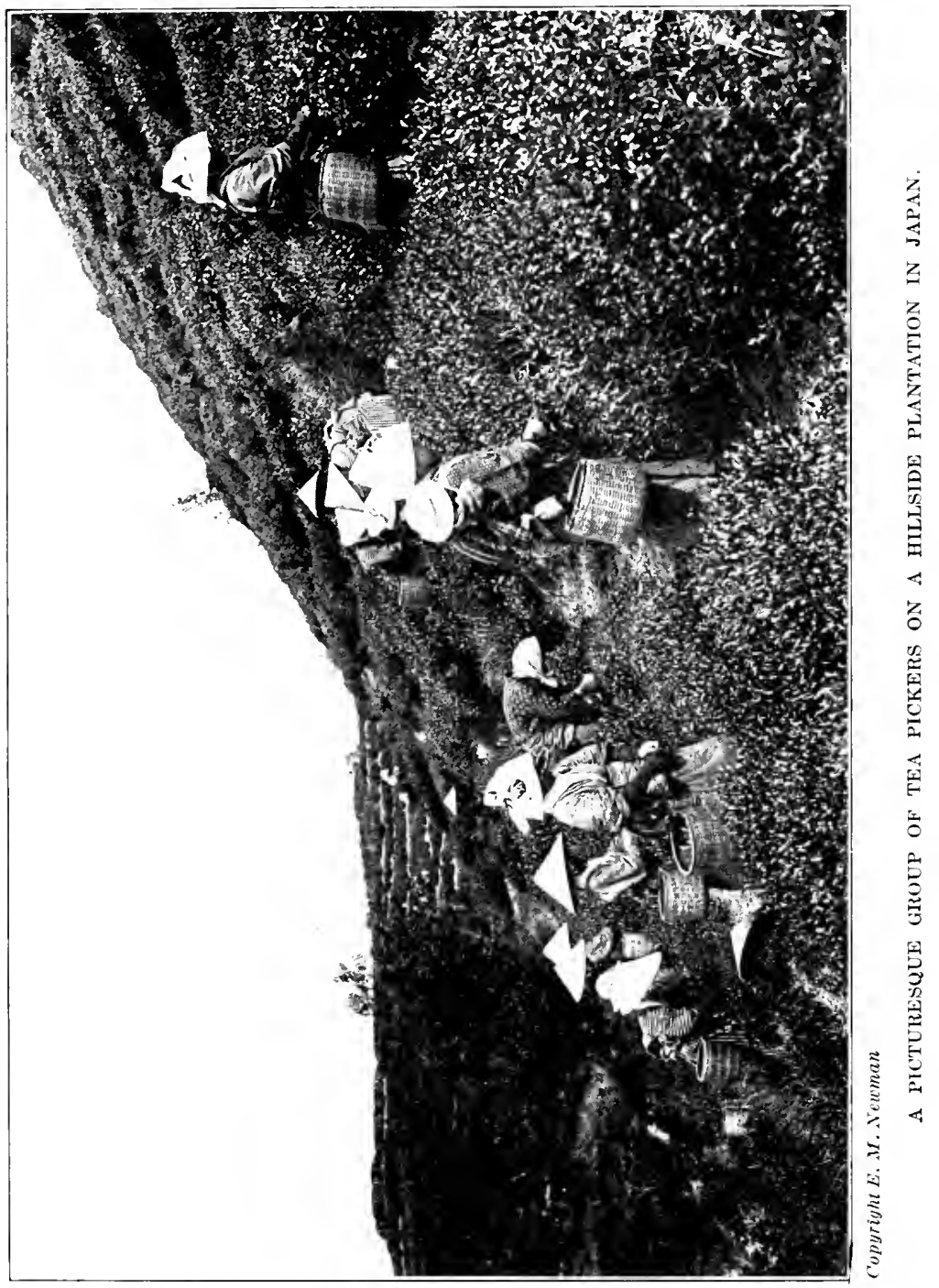


in a mighty army and navy. They are sincerely convinced that Japan's safety and future lie in having a dominating influence on the continent of Asia.

Japan would welcome American capital on a large scale to develop her own industries. She has a limited supply of coal and is anxious to develop good roads and construct new trolley lines. The United States will, as time goes on, be in a position to supply a good part of this demand but at the present time the apparent policy of Japan's military party will prevent any American coöperation on a grand scale.

As to the triumph of liberalism in Japan over militarism there are some who point to the recent agitation for universal suffrage in that country and also the evidence of a conciliatory policy in China advocated of late on the part of Japan. Popular discussions concerning "democracy" and the suggestion of labor reforms have also been pointed out as marks or signs of a more liberal policy. There has been also a reaction in the country against bureaucracy due to the failure of German militarism. Nevertheless, one of the progressive leaders, Yukio Ozaki, is reported to have declined not long since to head a labor party and gives to labor the advice of getting educated as the best means for future influence.

As a matter of fact, the Japanese or Tokyo Diet is lacking in authority to control Government action and until this body is given greater powers and influence democracy and liberal policies will be doubtful. The clan system is still very strong in Japan and this clanship of a few of the ruling families is an influence difficult to combat on the part of liberalism. The time must come when the Imperial forces have less power than to-day, and when the portfolio of war may be given to a civilian, before we can expect too confidently a liberal government in Japan, that will place commerce above the army and navy in precedence.

The interest of Japanese capitalists in labor problems does not seem to be as deep as the press reports have at times given one reason to believe. Mr. J. O. P. Bland 
writes from Japan in the early part of 1921, describing a Tokyo meeting of "big business men" connected chiefly with shipping interests, voting down as "quixotic foolishness" a modest plan for profit-sharing among workmen.

The industrial worker knows, or thinks he knows (writes Mr. Bland), that so long as the family system remains the foundation of social structure, the gospel of Karl Marx will make no more headway.

As to the labor movement it is significant to note that there are 25,000 factorics in Japan, employing over 2,000,000 workers, and that up to the present time the Government has declined to permit organization of labor unions. Furthermore there is no regular organized labor party in the country, nor have there appeared on the horizon any notable political leaders who seem desirous of leading such a party. Yet in the city of Tokyo with its active, teeming three millions of people, there is evidence of unrest and the older Japanese have cause to lament the passing of ancient Japanese virtues. Many of these sterner traits, according to some of the Japanese leaders, have been swept away by the new material industrialism.

Marquis Okuma is reported to have suggested not long ago that while the antagonism to Japan may have arisen from jealousy of her progress, nevertheless his countrymen may have waxed "selfish and conceited" by reason of their successful commercial and military policies.

Judging from the reports of those who have recently come from the Sunrise Kingdom there is evidently a fear among the soberer Japanese statesmen of the growth of suspicion of the Japanese trade integrity, particularly in such matters as trade-marks and unfulfilled contracts. The Japanese have a fear of "moral isolation," and this proud and progressive country will doubtless make many sacrifices rather than allow the new Japan to become isolated from the rest of the world. 
Many Japanese seem to have a feeling that further Chinese aggression may endanger the standing of Japan among the Western nations, yet between the ideas of commercial success and the dream of Pan-Asian imperialism both the bureaucracy and the masses of this country are wavering to-day.

Although there is a tendency among certain sections of both Japan and the United States to inject the military situation into national relationships, trade between these two nations has been steadily increasing during the last decade. In accordance with a summary published in September, 1920, in the Commerce Monthly, Japan is seen to rank third among the countries of the world in its contributions to the import trade of the United States. Cuba and Canada only surpass Japan in the value of imports into this country. As a purchaser of American goods, Japan is exceeded at present only by the United Kingdom, France and Canada. During the last fiscal year, the imports from Japan into the United States were almost as great as those from Argentina and Brazil together, while the United States exported to Japan materials greater in value than the combined exports to the four important South American countries-Argentina, Brazil, Chile and Peru.

Japanese imports into the United States between 1911 and 1920 doubled, increasing from 5 per cent to 10 per cent of our total imports; Japanese imports into the United States now form one-tenth of all imports into this country, while American exports to Japan are only a little in excess of one-twentieth of the total exports of the United States. In the year 1911 American exports to Japan amounted to $\$ 37,000,000$ or 2 per cent of our total exports; in 1920 these exports had mounted to $\$ 453,000,000$ or 6 per cent of our total exports. The following table from the Commerce Monthly summarizes the place that Japan has held in the foreign trade of the United States between 1911 and 1920: 
Foreign Trade of the United States in Relation to Trade WTTH JAPAN, 1911-1920

\begin{tabular}{|c|c|c|c|c|c|c|}
\hline \multirow{2}{*}{$\begin{array}{l}\text { Fiscal } \\
\text { Year } \\
\text { Ending } \\
\text { June } 30\end{array}$} & \multirow{2}{*}{$\begin{array}{l}\text { Total } \\
\text { Imports, } \\
\text { Amount } \\
\text { in } \\
\text { Millions }\end{array}$} & \multicolumn{2}{|c|}{$\begin{array}{l}\text { Imports from } \\
\text { Japan }\end{array}$} & \multirow{2}{*}{$\begin{array}{l}\text { Total } \\
\text { Exports, } \\
\text { Amount } \\
\text { in } \\
\text { Millions }\end{array}$} & \multicolumn{2}{|c|}{ Exports to Japan } \\
\hline & & $\begin{array}{l}\text { Amount } \\
\text { in } \\
\text { Millions }\end{array}$ & $\begin{array}{c}\text { Per } \\
\text { cent of } \\
\text { Total }\end{array}$ & & $\begin{array}{l}\text { Amount } \\
\text { in } \\
\text { Millions }\end{array}$ & $\begin{array}{c}\text { Per } \\
\text { cent of } \\
\text { Total }\end{array}$ \\
\hline 1911 & $\$ 1527$ & $\$ 79$ & 5 & $\$ 2049$ & $\$ 37$ & 2 \\
\hline 1912 & 1653 & 81 & 5 & 2204 & 53 & 2 \\
\hline 1913 & 1813 & 92 & 5 & 2466 & 58 & 2 \\
\hline 1914 & 1894 & 107 & 6 & 2365 & 51 & 2 \\
\hline 1915 & 1674 & 99 & 6 & 2769 & 42 & 2 \\
\hline 1916 & 2198 & 148 & 7 & 4333 & 74 & 2 \\
\hline 1917 & 2659 & 208 & 8 & 6290 & 130 & 2 \\
\hline 1918 & 2946 & 285 & 10 & 5920 & 268 & 5 \\
\hline 1919 & 3096 & 304 & 10 & 7232 & 326 & 5 \\
\hline 1920 & 5239 & 527 & 10 & 8111 & 453 & 6 \\
\hline
\end{tabular}

The present commercial conditions in Japan, particularly in relation to her trade with other nations, have been influenced decidedly by the last war. This war forced Japan to produce at home many things which she formerly imported, thereby greatly hastening her entrance into the world field of skilled competition. This has been especially true in her exportation of such articles as silk, tea, zinc, manufacturers of copper and brass, paper, glassware and cotton goods. There has been, moreover, a considerable increase of Japanese trade with other Oriental countries in machinery, hardware and tools.

The recent financial difficulties of Japan to which a number of Japanese bankers and business houses have fallen victims, was brought about largely by the extreme inflation of credit and speculation. The heavy accumulation of gold to Japan's account occasioned by the excess of exports throughout the years of the war was probably the primary cause of Japan's recent inflation. This amount of gold at the end of 1919 reached its largest dimensions and 
amounted to more than two billion yen. This was a tremendous change for Japan since her gold reserve in 1912, for example, was only $350,750,000$ yen. The results of this piling up of gold in the domestic market made money available at record low rates during the years of the war. The result was that every form of speculation was promoted and all kinds of enterprises-many of them of doubtful character-were accepted by credulous Japanese. As an example of some of these enterprises, there was a wild scheme for making a substitute for cotton out of seaweed. The immediate effect was the creation of boundless prosperity in Japan, but this paved the way to future depression and the tying up of all available capital. The record of these depressing times in Japan shows vast increases of bank clearances, cornering and holding, together with other varied forms of speculation.

Augmentation was the rule along many avenues of trade. Significant in this enlarging prosperity was Japan's shipbuilding movement. The total tonnage turned out in Japan in 1914 was approximately 78,010 tons, while in 1916 the figure rose to 141,827 tons. The following year the total amount was 349,455 tons, while the record for 1919 was 613,849 tons of shipping.

Because of all this boom period a later reaction was inevitable, since the sustaining power behind these widespread promotions, the excessive exports particularly, was spending its force.

Although in January of 1920 at the annual dinner of the Tokyo Associated Banks the Governor of the Bank of Japan declared that the prosperity of 1919 was a shadow of what it had been and that Japan's external commerce was bound to suffer a reaction, bankers and business men did not seem to heed the warning, drunk as they were, according to one report found in Eastern Commerce, with the "shadow prosperity" of the times. On March 15th, 1920, there came the first shock of the collapse in the Japanese business world when the Tokyo Stock Exchange was seized with a sudden panic and all turned free sellers. 
For two days following the Tokyo market was unable to resume business. Although on March 18 th the stock market resumed trading, the market was indecisive throughout the month of March. The second panic occurred on the 7 th of April with heavy slumps in the Exchanges of both Tokyo and Osaka. The immediate cause was the failure of one of the biggest bill brokers in Japan, the Masuda Bill Broker Bank. Although the Bank of Japan came to the rescue with eredit and the market resumed trading on the 13th of April, the following day marked a third crisis when the House was unable to continue business. Now the panic had affected almost all the lines of Japanese business and appeals were made to the government for help. During the first week of May the stock market secured the Bank's credit and a provisional settlement was effected. The stock exchanges in Tokyo, Osaka, and Nagoya resumed trading on May 10. Although minor panics followed, things have been slowly recovering. The immediate prospect for the stock market was stated about this time by an expert on Japanese market conditions, who said that the repeated slumps during the three months previous had forced down all shares to their lowest possible levels, but that while the market may stay around the level thus reached, for a time, the weak elements will gradually be eliminated and a more healthy tone be restored. In Japan, as in the United States at present, there is evidenced a great tightness of the money market and the effect of inflation has been felt strongly upon the market in the textile industry, the silk industry, the cereal trade, as well as in the steel, pig iron, copper and in the freight market and shipping circles. Although it will probably take some time for Japan to recover fully, the eountry is financially sound, and if the people take to heart the lesson that business ean be eonducted not through the gambling spirit but only upon sound legitimate business principles, this country will evolve from the finaneial difficulties and be strengthened by her experienee in her future commereial and financial activities

With the certain return of Japanese financial and eom- 
mercial strength to the competitive markets of the world, the question of this country's competition in Japanese goods imported into the United States since 1911 becomes an important one. Can the Japanese compete in the domestic markets of this country? This depends upon several conditions.

The matter of distance is always an important element in trade competition. Yokohama is 4536 nautical miles from San Franciseo and 9699 miles from New York by the way of the Panama Canal, and 8414 miles by water and railroad via San Francisco. This fact is a dircet handicap to Japanese competition particularly in the heavier classes of commodities which the United States ean produce by reason both of her native resources and her ability in labor ${ }^{\circ}$ supply. Although Japanese competition may become a threatening influence to American interests on the Pacific coast, it must be remembered that the vast percentage of the purchasing power is east of Denver and that 90 per cent of the population of the United States lies east of that city.

Moreover, it must not be judged that the Japanese have superior competitive ability over us simply by the measurement of relative labor costs. Wages in Japan have naturally advanced to meet the increased cost of living, but in addition to this fact wages in terms of money are not a criterion to ability in competition. The true basis of comparison lies rather in the "quality and quantity of product as measured by costs per labor unit" as a economic writer points out. Furthermore, for Japan to become a serious competitor with the United States along lines in which this country is fitted to produce, she must not only have lower labor costs but enough lower to offset the freight charges and the many difficulties of marketing in a foreign country. It is also a question whether the reputation which Japan has had at times for manufacturing inferior goods, especially in such lines as toys and small articles, will not make for her an additional handicap in competing with the high quality of American manufacturers. As far as this subject 
is concerned, it is our belief that the competitive elements of comparative advantage or disadvantage are fairly well distributed between the two nations, and the American inventive genius, skill and organizing ability are not to be overlooked as means of keeping the United States to the front in this or any other similar competition from a distant land.

The fact of mutual markets is revealed to be something more than a slogan because the articles which are most generally imported from Japan are not produced in our own country to any great extent, and vice versa. For example, in the production of silk, tea, camphor and such produce as beans, peas, soya bean oil, peanuts for oil and what is known generally as "Oriental goods,' Japan may have a large market in the United States, without endangering our own products. To quote from a San Francisco newspaper which published some time ago a list of articles taken from the invoice of a steamship reaching San Francisco from Kobe, the general character of Japanese imports to the United States may be discovered.

$6 \mathrm{pkgs}$, silk goods

49 es. crockery

19 cs. chinaware

3 es. paper fans

170 es. shelled peanuts

679 es. eanned crabs

620 grass rugs

15 bbls. sparteries

37 es. beads and strings

1 es. paper tape

8 es. bronzeware

2 es. vacuum flasks

287 bbls. hemp braids

366 bbls. straw braids

47 es. straw hats

100 bbls. cotton thread waste

5 es. bristles

35 es. paper hats

65 es. umbrella handles

69 es. brushes
187 es. porcelain ware

5 es. woodenware

43 es. incense and clay ware

75 cs. toys

700 cs. white arsenic

10 bbls. agar agar $6200 \mathrm{bgs}$. potato starch

60 drums safrol

3 bbls. jute carpets

5000 cs. peanut oil

40 cs. insect powder

200 bgs. chillies

2 cs. lacquered ware

10 es. dolls

15 es. imitation gold leaf

171 es. kid leather

124 es. fishing poles

3 es. merchandise

2 es. curios

1 crt. baskets 
In return for such purchases Japan is enabled to buy from us raw, manufactured and semi-manufactured materials which the United States produce in excess of domestic needs. Such materials may be suggested as raw cotton, iron and steel, machinery and engines, kerosene oil and chemicals. Thus reciprocal and mutual trade advantages are served and a sound basis exists for an ever enlarging selfish advantage on the part of both Japan and the United States of trade with each other. In fact, it must be remembered that 60 per cent of the iron and steel purchased by Japan in 1919 was from the United States and 80 per cent of Japan's imports of kerosene oil came from this country. Those who would promote jingoistic doctrines and endeavor to embroil the United States and Japan in war may remember with profit that Japan is more dependent upon the United States for her trade than upon any other single nation, and that, in a sense truer than we sometimes appreciate, trade rules sentiment as well as the pocketbook of the world.

Other commodities might be cited such as cotton, which is probably the largest single commodity exported from the United States to Japan. This export of American cotton to the Sunrise Kingdom has grown from 323,202 bales in the fiscal year 1900 to 881,041 bales in the calendar year 1919. It would seem sensible to believe that, with the tendency of Japanese cotton manufacturers to produce finer yarn and higher grades of cotton piece goods, American cotton would hold an ever enlarging place in inter-trado relations between the two countries.

In view, therefore, of the progressive and rapidly expanding commercial life of both these nations, and realizing the inter-dependence of Japan and the United States upon each other in a commercial interchange of goods and produce, the future of trade between the two nations would seem to be a permanent and ever enlarging actuality. Only let the trader remember that trade is a shuttle running both ways, and that both parties to the commercial contract 
must secure advantage, if the trade relationships are to bo lasting.

Japan needs the trade of the United States and the United States cannot afford to lose the trade of Japan. These facts contain the inevitable reasons for mutual markets between the two countries. 


\section{CHAPTER XVII}

\section{STRENGTHENING AMERICAN TRADE WITH CHINA}

Our trade with China, like our commeree with certain other far-away countries, has suffered because of wrong conceptions or perhaps from false traditional ideas which are usually hard to dislodge. I once asked a theatrical producer why he persisted in making his Chinese characters wear queues or pigtails when the Chinese men have long ago discarded these in China, also why he made Japanese men wear bright kimonos on the stage, when, as a rule, only Japanese children wear such bright colors in the Sunrise Kingdom, the men being clothed in garments of sober hues. He answered:

Why, the American public always think of Chinamen as having pigtails and the Japanese in bright-hued kimonos. They wouldn't like it, wouldn't be satisfied unless we did it on the stage, any more than the public would recognize a preacher before the footlights without a clerical waistcoat, a flat hat and carrying a prayer book.

In other words, custom has worked against a true understanding of foreign countries. This has been true not only on the stage, but also in our literature and often in our conversation. Foreign countries are far away in thought to the average American. The result is that when we come to the opening of the great trade routes to the Orient, as at present, we find ourselves lamentably lacking in information concerming actual conditions in the Far East. Nor have these misconceptions been dissipated greatly by our usual American travelers who have gone to the East in a 
band of tourists, personally conducted by one or more superficially informed American dragomen. These guides, outside of a knowledge of steamer and train schedules and certain details of port bargaining, are usually blissfully ignorant of the intent, motives, history and race characteristics of the Oriental.

To understand an Easterner requires more than a globe trotting journey in a Cook party; it means something beyond and other than living in European hotels, or gathering up souvenirs, or talking with donkey boys or coolie servants. To understand an Easterner enough to be able to do business with him, a man must set his attention upon the history, language, customs, geography, together with the laws, religion and predilections generally of a foreign nation. Such attention we have not yet given to China. Until we can really seize this truth, and take definite steps as a nation to mend our ways, we shall see our possible trade go to other countries, better equipped with method as well as with knowledge than we are.

Previous to the European war there were only three or four important American firms doing business in China and our percentage of China's foreign trade according to the report of the Committee on the Judiciary in Congress, amounted to about 6 per cent. The balance of Chinese trade went to Great Britain, Germany, France and Japan, with smaller amounts to various other countries. Because of the unusual stimulus given to our trade in the Far East by reason of the war, our percentage in foreign commerce with China is at present about 17 per cent or in the year 1919 at least amounting to $\$ 287,000,000$. The number of American firms commercially interested in China included in the membership of the American Chamber of Commerce in China at Shanghai has increased from 48 in 1915 to 313 in 1920.

These companies for the most part are comparatively small firms, representing manufacturers in the United States and promoting the sale of products such as machinery, hardware, cotton and cotton manufactures, food prod- 
ucts, motor cars, typewriters and office supplies, wearing apparel such as shoes, underwear, hosiery, shirts and collars and clothing materials, paint and varnish, building equipment such as lumber and nails, electrical equipment, locomotives and freight cars, general railroad equipment such as rails, bridge materials, and timber, dyes and chemicals, kerosene, tobacco products and products of our mines such as iron and steel which are used for construction purposes. In general, it may be stated that China at present constitutes a wide market for practically everything produced in America.

In order to make it possible for the United States to enter this expanding field of trade among one of the oldest and most numerous populations of the world, certain legislative changes are required. It is to meet such needs of American trade that the China Trade Act has been brought to the favorable attention of the President, of the Secretary of State and the Secretary of Commerce, who have indorsed it, and it possesses the promise of being enacted into law and thereby greatly facilitating the development of our Far Eastern commerce.

The difficulties which this China Trade Act is intended to overcome were outlined in the report of Mr. Dyer from the Committee on the Judiciary in the House of Representatives and are summarized as follows:

China is an ex-territorial country, which means that all foreign merchants doing business in China must, by treaty, do so under their own laws and regulations.

For example: Americans must do business under American laws; British under British laws; French under French laws; Japanese under Japanese laws; and so on. This is due to the fact that the young Republic of China has not yet codified her laws and modernized her courts to the extent that foreigners may become subject to them. Practically every country interested in the China trade, and this applies especially to our strong competitors, has adopted special laws for the control and promotion of its business in China. America has never done this, and as a result American companies doing business in China 
are subject to the conflicting corporate regulations of the various 48 States and our Territories. This factor handicaps us specifically as follows:

First, there is no uniformity, none of the State laws being adapted to foreign trade purposes, and several of the State incorporation laws being lax, permits the promotion of a great deal of undesirable business, such as fly-by-night promotions that are very damaging to our prestige with the Chinese business men.

Second, our chief competitors in China are the British, Japanese and French, the French competition not being so serious. The British, Japanese and French have enacted special regulations governing their companies in China, exempting them from the operation of home income and excess profits taxation. This places the American firm at a distinct disadvantage, since it can not build up the necessary reserve to carry over the years of depression and uncertainty. In prosperous years the American firm can meet the competition, but in slaek times such as the present the American firms are going bankrupt, while our competitors are going along and getting the business.

Third, the operation of the home income and excess profits taxation under the various State regulations, upon our companies in China, prevents the Chinese business men from forming joint enterprises with American business men. The Chinese are now striving to develop their country industrially and are anxious to coöperate with American merchants who are experienced in the management of industries on a modern basis. Since this Chinese capital coming into an American company is taxed the same as the American capital, the Chinese are thus prevented from coöperating with us and are forced to invest in British and Japanese companies, thus throwing the resulting purchases of equipment and other business to those countries instead of the United States. The British have taken advantage of this desire of Chinese business men for western experience and management and have built up much of their great business in China in this way; that is, by attracting Chinese capital. The lack of a uniform high standard American corporation law governing our business in China debars us from these partnerships with the Chinese and this coopperation is the outstanding element in the new development of China.

Hundreds of Chinese young men who have been educated in our colleges and universities and engineering schools are anxious 
to coöperate with Americans in the development of China, using American materials, but they are debarred by our failure to enact legislation providing the machinery for coöpcration. In short we have educated these young men in our ways of doing business, but when it comes to actually doing the business we shortsightedly permit them to go to the British and Japanese.

Since China is the only country where we operate to any great extent under extra-territorial treaties, a general law will not and cannot solve the problem of American business development in China. Furthermore, the present period of depression combined with famine conditions in China will not permit delay if we are to hold our position and take advantage of Chinese friendship for Americans and American institutions. If we cannot obtain the assistance, our trade is certain to recede to the unimportant position it occupied before the war.

A glance at the history of our relationship with China reveals the fact that the opportunity of doing everything in our power to extend American trade in this giant country is paramount. The commereial languages are Chinese, English and French. The money is the tael, which is a unit of weight for silver. This unit varies in weight and value in the different distriets, and its exchange value fluctuates according to the market price for silver. This country, which occupies a territory one-sixth larger than continental United States, possessing a population four times as large as ours with similar climatic condition and natural resources, has received for many years the effective service of our missionaries and educators while the "open door" " policy has helped to strengthen the confidence and good will existing between China and the United States.

Furthermore, our trade relationships with China date back for more than a century. One hundred and thirtysix years ago an American ship visited Canton, China, with the result that a regular route was opened. In 1778 the first American clipper ship visited China and from that date until 1860, when our sailing ships were practically driven from the seas by the development of the British merchant marine and by our own interual development, 
commerce with China was an established fact. In the year 1825 American shipping and trade held the leadership in the Far East.

The following figures relative to China's trade with America, taken from the Chinese customs reports, show a decided growth between the years 1904 and 1919, our trade with China having nearly quadrupled in 15 years:

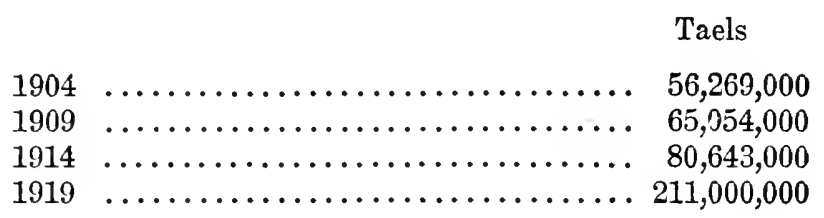

The figures which follow reveal also the encouraging fact of America's standing in relation to the four principal nations in the Shanghai trade for 1919:

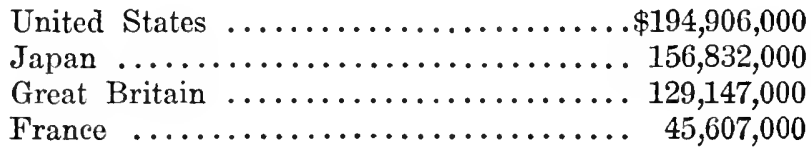

Although our commerce with the Far East has made only a beginning, there has been notable progress especially in the port cities of China during very recent years. It is estimated that more than 70 American firms established branches in China in 1920. During the fiscal year, 1919, American merchandise to the value of $\$ 117,000,000$ was shipped to China as against $\$ 57,000,000$ in 1914 . This is significant in view of the history of American trade with the Chinese in the past decade. In 1860 the United States possessed nearly as many cargo ships as Great Britain and we then controlled 47 per cent of Chinese trade.

The American Chamber of Commerce in China has prepared statistics showing the imports with percentage which came from America in 1918: 


\begin{tabular}{|c|c|c|}
\hline Articles & Value & $\begin{array}{l}\text { Per Cent from } \\
\text { United States }\end{array}$ \\
\hline Automobiles.. & $\$ 1,518,666$ & 48 \\
\hline Cigarettes..... & $28,612,390$ & 47 \\
\hline Coffee......... & $1,072,288$ & 49 \\
\hline Cotton, raw. . & $7,242,126$ & $6 \frac{1}{2}$ \\
\hline Cotton, gray shirtings... & $12,157,359$ & 4 \\
\hline Dyes: Paint and paint oil. & $1,265,331$ & $13 \frac{1}{2}$ \\
\hline Electrical materials and fittings. & $4,930,900$ & $20^{\circ}$ \\
\hline Furniture and materials for...... & $1,338,981$ & 23 \\
\hline \multicolumn{3}{|l|}{ Iron and Mild Steel: } \\
\hline Bars, new.... & $3,739,522$ & 37 \\
\hline Nails and rivets.... & $2,114,502$ & 27 \\
\hline Pipes and tubes..... & $3,444,921$ & 64 \\
\hline Sheets and plates... & $3,619,987$ & 48 \\
\hline Galvanized sheets. . & $1,209,203$ & $43 \frac{1}{2}$ \\
\hline Galvanized wire... & $1,100,906$ & 45 \\
\hline Steel bars, hoops, sheets, plates, etc. & $3,094,833$ & 58 \\
\hline Tinned plates $\ldots \ldots \ldots \ldots \ldots \ldots$ & $5,039,511$ & $40 \frac{1}{2}$ \\
\hline Machinery, textile..... & $1,968,538$ & 9 \\
\hline Medicines........... & $6,105,717$ & 5 \\
\hline \multicolumn{3}{|l|}{ Oil: } \\
\hline Kerosene. & $33,690,351$ & 35 \\
\hline Lubricating. & $2,180,351$ & 61 \\
\hline Railway materials (excluding sleepers) & $8,641,572$ & 17 \\
\hline Paper.................. & $1,693,754$ & $49 \frac{1}{2}$ \\
\hline Shoes and boots, leather.... & $3,020,615$ & $66 \frac{\overline{1}}{2}$ \\
\hline Tobacco............. & $6,739,182$ & $47^{\circ}$ \\
\hline Wax, paraffin.. & $1,341,212$ & 35 \\
\hline
\end{tabular}

It will be seen that a notable item in the above list is for electrical supplies, and when it is appreciated that there are 1500 walled cities in China which are not furnished with electricity, gas, street railways or waterworks, the opportunity for the advancement of trade along this line is apparent. Furthermore, coal and water are plentiful in China. It has been estimated that China has enough coal in her vast reaches of territory to supply the world for one million years.

The open door for American machinery is also significant. Since the invention of the cotton gin, China's cloth- 
ing has been revolutionized, while farming machinery and the use of all kinds of agricultural implements will have an increasing market as soon as our manufacturers and exporters have been able to ereate a market among the conselvative Chinese eultivators for these western appliances.

While transportation in China is naturally slow, the country has river navigation that is important for trade, the Yangtze, for example, being navigable for ships for 600 miles to Hankow and from this city many of the railways radiate and Chinese highways find their center. It is significant to note that a company has been organized recently in the north of Shantung to operate a fleet of 50 American motor trucks to earry produce to the seaboard.

Onc needs only to appreciate these vast populations numbering more than 400,000,000 closely concentrated along the rivers and coastal regions with an excellent climate, a tremendous coast line, and not to mention others-the Yangtze River, 3200 miles long; the Yellow River, 2600 miles long; and the West River, 1200 miles in lengthfurnishing vast opportunities both for transportation and water power.

In order to make China, which is manifestly one of the greatest potential buyers among the nations, a present opportunity for the largest American trade, it is neeessary that our manufacturers and exporters appreciate tho definite things that China needs at present such as machinery to develop her industries, and financial assistance such as is being rendered through certain banks, notably the Sino-American Bank. There is need of a trade policy that will be continuous regardless of political changes at home or in China, also regardless of international polities, delays and the difficulties attendant upon experimenting in business with a foreign land. Trade with China as with other foreign nations has been too much a temporary matter, some thing to be taken up for a trial rather than entered into as a policy of the house, strongly backed by eapital and able leadership.

A necessity of legislation is also required to make it 
possible for American traders to do business in China in competition with foreign firms; it is especially needful that our laws relative to immigration be modified in such a way as to admit at least Chinese students who are eager to come to this country to study our machines, our factories and to get technieal knowledge in our schools. At present these students cannot come to us easily; the requirement of $\$ 500$ on landing being a bar in many cases and these young Chinese are looked upon as laborers by the law. No such rules keep Chinese students out of other nations. France, for example, is inviting earnestly Chinese students to come to that country to learn to use French machines and, instead of making travel to France difficult, plans are being made for cheaper rates of travel for Chinese students. Nearly 1000 Chinese students are already in France, and it is estimated that between 5000 and 6000 Chinese students will pour into France within the next two or three years. The German and Japanese colleges are being avoided by the Chinese at present and it is a very opportune moment for the United States to take action that will make possible a larger influx of Chinese students into this country for the purpose of preparing themselves for Chinese industries. Such youth will carry back from this country, not only good will, but a knowledge of our scientific and mechanical appliances such as will naturally cause the Chinese to look to the United States for an industrial market. Great Britain has seen the successful result of donating machinery to Hongkong University, since it is natural for a country to follow its knowledge and acquaintance of imported products with orders.

A suggestion has been given in an address before the American Manufacturers' Export Association by Commercial Attaché, Julian Arnold, of Peking, who advances a definite suggestion to American exporters sceking connection with Chinese markets:

Let us have in Shanghai (said Mr. Arnold), an American industrial exhibit, not a permanent exhibit, not a thing that will be a dues collector, but an exhibit that will last for a period 
of three or four months. These people want to see our materials. It is true that our merchants in Shanghai-we have two hundred American firms in Shanghai, two thousand Americans in the population there, and an American Chamber of Commerce there -it is true that the organizations have their showrooms and exhibit rooms and they exhibit certain American machinery and the other materials they have to sell, but the Chinese don't know where it is and they can't find it.

Now, it would be well for us if we ereated in Shanghai an exhibition hall where we could put for a period of three or four months certain manufactured articles which would commend themselves to the Chinese to-day, as Shanghai is the great trading center of China, and the Chinese come from all over China down there, the same as people here come to New York, only that we find Shanghai is the Chicago and New York of China combined into one, and 60 per cent of China's import and export trade goes through Shanghai. It is a very strategic center.

If the American Manufacturers' Export Association wants to do something for its future in China, it will be a splendid thing for it if it will try to develop an exposition of American products. It probably would be well to do it with the organization in China so that if you are giving an exhibition of American toilet articles or building materials or hardware, there is somebody on the ground who can explain it to these people and who can follow up a possible order for goods and can cash in on it. We want it there for business purposes, not for academic purposes.

I will give you a few lines that would be very effectively exhibited in that place. There is high-class cotton goods, but our finer grades of American cotton goods will command a better market in China when there is a better selling organization there for the exploiting of the possibilities in that direction. Then certain clothing, shoes, hosiery, garters and hats and articles of that sort. Recently, the Chinese Industrial Guilds, a new organization in China, came together, and I read a Chinese paper the other day showing they wanted to know if it was possible to get American hats at less than eight dollars apiece, having them made in two or three lots and getting them cheaply enough so that they could buy them. The trouble to-day is that a great many firms are more or less profiteering on this exchange rate, so that it ought to be possible to get American hats for less than eight dollars. 


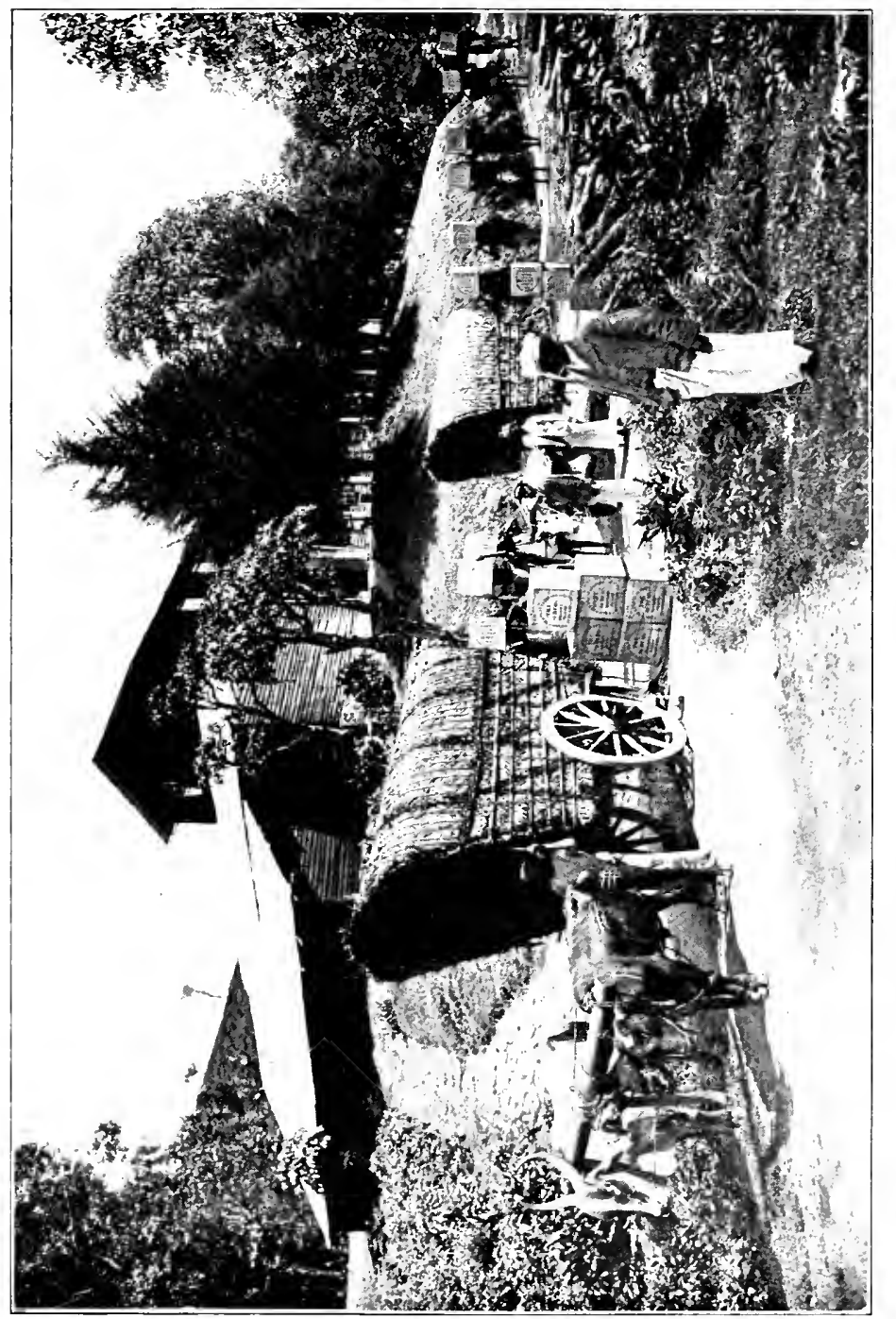

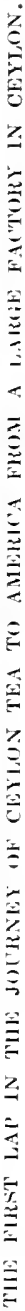




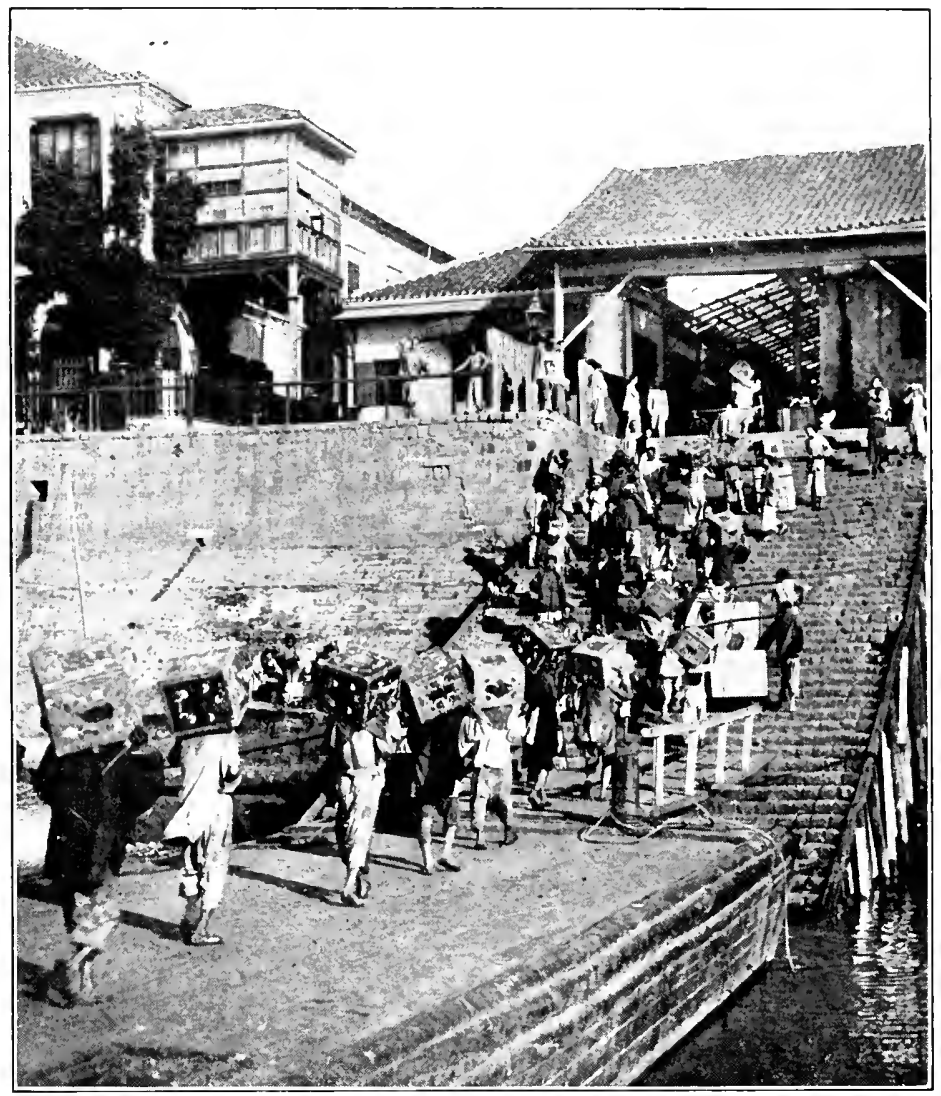

Copyright, L'nderwood \& Underwood, N.Y.

COOLIES CARRYING CHESTS OF GOODS ON THE HANKOW WATER FRONT. HANKOW, ONE OF CHINA'S MOST IMPORTANT CITIES, IS SITUATED AT THE JUNCTION OF THE YANG-TSE-KIANG AND HAN RIVERS AND IS REACHED BY MERCHANT VESSELS. 
Then again, there is a demand in hardware, the building hardware. The Chinese are going to rebuild their cities. In Shanghai to-day there are new stores going up and they are built in a modern fashion and they want American hardware and fittings and plate glass windows. Shanghai is to be rebuilt in the next few years. Already they have about ten million dollars' worth of building contracts to let. When a man puts up a building of a modern sort in China the other man is shamed into it. One of them gets started and then all the people on the street follow suit.

In notions and toilet articles and dyes the market is open. 'The Chinese people don't realize that we can manufacture dyes. People have told them that we could not make dyes. It is up to us to put up an exhibition and show them we can make dyes. Then there are such things as graphophones and motor cars; also modern plumbing materials, knitting machines, modern looms. They are putting in cotton mills and buying them faster than we can make them; grinding machines, flour mills, agricultural implements of a certain sort; a plow adapted to the Chinese conditions would be very successful. The purchasing power of the Chinese is liigher than that of the Philippines. We can give the Chinese a plow which they will use largely, if we investigate and make a plow that will fit their conditions.

There are large possibilities in trade in modern furniture, beds and things of that sort; also tinned fruits, and clocks and watches and candies and school and laboratory apparatus. The people are building their schools very rapidly and they want all appliances in that direction.

Certain large American business concerns like the Singer Sewing Machine Company, The Standard Oil and the American Tobacco Company, together with a few of our American banking enterprises have penetrated somewhat into the interior cities and towns of China, but as for American trade generally having reached the vast populations pressed closely into their 4,300,000 square miles (an area 11/2 times that of the United States, excluding Alaska - a population with only 6000 miles of railway as against our 260,000 miles), only a slight beginning has been made. It is a huge task that confronts us--the capturing of the thought as well as the trade life of this vast, 
conservative, superstitious, slow-moving and sensitive, frugal and industrious nation-Orientals with all the subtlety and mystery embodicd in that term.

We would commend, for those particularly interested in American trade with China, the two articles appearing in the May, 1920, issue of Asia. One of these articles is by Prof. John Dewey, who has traveled recently in China and presents thoughtfully his reasons for the great conservatism of these people. One of the main reasons, he states, is the closely packed communities in which even a slight innovation or change is inclined to dislocate life, cause trouble and disarrange business, for which the Chinese care more than for almost anything else; the other article is by $\mathrm{H}$. K. Richardson, an engineer, who narrates concrete examples of successful American business in inland China gained from a somewhat unusual experience investigating mining and river conditions in that country.

$\mathrm{Mr}$. Richardson speaks of the possibilites of AmericanChinese business partnerships and declares that American selling methods will find the Chinese mind ready to act at present and that there is a great need in China of education along modern methods of keeping books, financial procedure and the proper balancing of stock and choosing proper locations for business. To the neglect of such matters are attributed 70 per cent of the Chinese failures in business. The article is composed of a narration of incidents relative to Chinese shopkeepers and mechanics by one who is evidently acquainted with the detail of Chinese daily business procedure, especially from the native point of view. Ho shows the signs of progressiveness of the Chinese as they have followed American and European methods, the manner of displaying foreign importations in line with western advertising methods, etc. He emphasizes the great nced to teach the Chinese proper advertising methods since much of their stock is unknown to the foreign communitics of the larger cities. He suggests that American manufacturers form an association to place good advertising men in the field to guide the Chinese merchant along new paths, back- 
ing up these promoters in the interior provinces with a store of goods which the Chinese merchant could buy for cash and obtain delivery in a short time.

Among the most profitable things for Americans to stock and sell, the author states, would be goods usually sold in 5 and 10 cent stores in the United States, such as, cheap tools, shears, perfumes, soaps and jewelry. All these remarks refer to inland Chinese cities. The motion pictures are of great use in such a campaign of education.

Another American opportunity presented is the modernization of the older Chinese industries by the introduction of American machinery in the factories to make Chinese products like silk, for example, conform to the standards of the rest of the world. The author suggests that such industry should be followed along the line of the family system so strongly intrenched in China-small industrial units being formed in the control of a single clan.

The author believes that the great industries will have to be financed by foreign capital or a combination of Chinese and foreign capital-the Chinese being given a large share in the operation, since a strictly foreign corporation is looked upon with suspicion in such sections as Szechuan. He illustrates how American big business has shown the way in the establishment of the American-Chinese Bank at Peking, financed and backed by a combination of the Pacific Development Corporation interests of New York; Hayden, Stone \& Company, bankers, Boston, and the Chase National Bank of New York. This is only a beginning of great things in the American-Chinese joint capitalistic development of China.

It has been my privilege to make two somewhat extended visits to China. While no one can pretend really to know the Chinese by visits of a few months' duration cren if these montlis are thoughtfully and carefully spent in investigation, one becomes convinced that these people are among the steadiest, the most intelligent and the most promising commercially of all Eastemers. The Chinese are worth our study and American trade with China is worth sacrifice. 


\section{FOREIGN TRADE MARKETS AND METHODS}

It will repay all the costs to get our salesmen, our representatives who are to live in China, well-grounded in the Chinese language, as do other nations, and to learn of the many differences between ways of doing business in the antipodes and the manner in which we carry it on in New York and Chicago. One trouble with our American trade in the East lies in the fact that we have tried to get our fitting and equipment for it at a bound. Infinite pains and dogged determination and perseverance are required to learn the Oriental, the motions of his spirit, and his manner of trade.

It is true of China as of India that "slow siege" is the better plan. In an interview with $\mathrm{Dr}$. Wu Ting Fang, former minister to the United States, in his spacious home in Shanghai, he said to me shortly before the war: "You Americans want to go too quick for us." On another occasion this Chinese diplomat and astute student of things East and West is reported to have said:

An American is apt to be in too much of a hurry. He should make up his mind that if he has an article that the Chinese want they will buy it eventually but, that it will take a little longer to introduce his goods in China than in the United States; but he should also remember that once he gets his article established it will continue to sell for a long time and indeed will never be displaced until another article of the same kind, but of conspicuously higher merit and eheaper, is introduced.

The Chinese nature is not much different from that of other human beings. What at first is a luxury soon becomes a necessity in China as elsewhere. I have seen this demonstrated in Shanghai. A young merchant from the interior comes to Shanghai for the first time. $\mathrm{He}$ is taken about and entertained by the local merchants. He is introduced to some of the delights of the modern civilization. After that he is never the same man. $\mathrm{He}$ longs for luxury once he has tasted it. He likes the cigarettes; he likes the scented soaps, the wincs, perfumery, foreign clothes, automobiles, upholstered furniture. It is largely beyond his reach because of its cost, but as he begins to feel better financially he adds to his stock of foreign introduced luxuries, and enjoys them. 
How are we to go to work to capture more completely a trade with a country where our imports are still far in excess of our exports, in fact nearly three to one? That our trade has increased rapidly within the last ten years, nearly 100 per cent in fact, until it now amounts to over $\$ 300,000,000$ a year, is encouraging-if you do not consider the greater trade of Britain for example. But to-day is the acceptable time for the promotion of Chinese trade. This old country is rapidly becoming a new land in her westernization and the progressive spirit of her youth educated abroad. China is at the threshold of her modernization. Her industrial development is at hand. The field is tremendous. One-half of the population even now are without wheeled vehicles. China requires railway materials and mining equipment on a vast scale. She wants public utilities, electrical plants, agricultural machinery, factory equipment and all kinds of metal products. As Sir Robert Hart says :

China may not know she wants these things, but it is part of our task to ereate the desire for these manufactured products that belong to the psychological moment in Chinese history.

China is for us in a peculiar way a field of unique and rich possibilities because of our past relationships with her. It was our country, through the efforts of John Hay, that brought in the emancipating trade idea of the "open door" for China. No country in the East needs our help at present more than China, groping for a settled government, desiring new trade relationships with the West, and striving, often unsucessfully, to maintain her independence and territorial rights in the face of encroachments of stronger nations both East and West. 


\section{CHAPTER XVIII}

\section{TRADE POSSIBILITIES AND INDUSTRIAL PROGRESS IN THE PHILIPPINES}

It would seem to be a comparatively small population, 10,500,000 people, inhabiting the Philippine Islands, but the territory, comprising some 3141 islands of all sizes and conditions of eivilization and barbarity, contains 115,026 square miles, a larger arable area than that supporting $50,000,000$ Japanese. The country, moreover, has had a ehance for development that is measured by centuries, Manila being founded in 1571, shortly after the Islands were discovered by Ferdinand Magellan.

There is a kind of "lives-there-a-man-with-soul-so-dead" sensation trickling up and down the spinal columns of most Americans, as, after months of Asiatic wanderings, they look out of their cabin windows on a tropical morning upon the headlands of Luzon, and, sailing calmly into Manila Bay, pass the rock island of Corregidor, and get a glimpse of the floating colors at Cavite.

The American is more or less mindful of that May day in 1898, when, by one tragic stroke, Admiral Dewey and his flcet ended Castilian supremacy in the East, and involved the noncolonizing American in that which has been, for this Occidental of the Occident, one of the most incongruous and unique enterprises of his history.

When one sallies forth to get his bearings and orientation, travelerlike, after his first dinner in a new land, there are signs enough of Yankeedom to make the native of the United States quite comfortable.

It is something to be able to wander through streets 
whose signs talk to you of Babbitt's soap and Boston garters, and to feel again real ice cold chocolate soda water percolating into your anatomy through a regulation, dust specked straw in an all-American drug store, while your listless eyes gloat upon advertisements of Bull Durham or fall perchance upon the hirsute countenances of the Smith Bros. There are indeed, certain parts of Manila, this metropolis of our American far-flung battle line, 11,600 miles from New York via Suez, with its nearly one million of people where, but for the Spanish padres, two-wheeled sulkies, and an occasional touch of medievalism in an old cathedral, you might easily feel that you had dropped by mistake into a city of Texas near the Mexican border.

The Americans, military or official, have not been recreant to their new and gigantic tasks. In less than twenty years they have brought to a decadent, belated land the rejuvenation of a scientific and industrial new birth. They have taken this monsoon, semi-tropical land for which the United States paid $\$ 20,000,000$ indemnity to Spain, and have touched it with the magic wand of modernity. New and broad highways, sanitary improvements, city buildings of Western pattern, trolley cars and ice plants, pure water and a system of industrial and primary education hardly surpassed in Asia. All these things have sprung up as in the night before the ever efficient genius of the American, arch apostle of utilitarian progress.

Five hundred miles of steam railways now carry the population and the products of the soil, which are mainly sugar, hemp, rice, cocoanut, coffce and lumber. These same colonists have converted the city of Manila, which only a few years ago served as a dumping ground and sanctuary for grafter's and criminals and the expatriated mon and women of Eastern Asia, worse even than any Lcvantine Port Said, into a city of order and cleanliness. They have carried out the idca of the early governors, and have placed Filipinos upon the Governing Commission, teaching them the fundamental principles of self-government by participation in local authority, a thing which England did not learn 
to do until she had been fifty years in India, and then not entirely at her own unaided volition.

The following figures relative to population, exchange, gold reserve and principal exports have been recently gathered by the World Map Company, and will reveal the basic facts required by the world trader:

Population, 8,918,000 (1917).

Exchange, Par. 1 peso-\$0.50 U. S. (\$0.4875, Nov. 18, 1919).

\begin{tabular}{|c|c|c|}
\hline Principal Exports & $1912-1913$ & $1917-1918$ \\
\hline 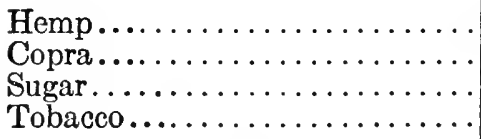 & $\begin{array}{r}\$ 23,000,000 \\
11,700,000 \\
9,500,000 \\
5,400,000\end{array}$ & $\begin{array}{r}\$ 54,500,000 \\
9,500,000 \\
13,300,000 \\
10,700,000\end{array}$ \\
\hline $\begin{array}{l}\text { Total imports }(\$ \text { U. S.) } \ldots \ldots \ldots \\
\text { Total exports }(\$ \text { U. S.) } \ldots \ldots\end{array}$ & $\begin{array}{r}\$ 54,550,000 \\
50,320,000\end{array}$ & $\begin{array}{l}\$ 83,800,000 \\
114,580,000\end{array}$ \\
\hline
\end{tabular}

During the past five years the products of the Philippines have been in great demand and a total trade balance of over 200,000,000 pesos has been built up in favor of the Islands. On August 31, 1919, the cash balance in the treasury was $141,181,050$ pesos. The currency in circulation was $136,674,619$ pesos. On the same date, in 1918, the treasury balance was $169,000,000$ pesos and the currency in circulation $126,000,000$ pesos.

The above figures give the impression of very favorable conditions, but while the Islands are undoubtedly in a stronger position than before the war, the situation is in reality not so favorable as statistics present it. The war brought prosperity, but its ill effects are now beginning to tell. The local financial situation is uncertain, and the currency is inadequate. Exchange with the United States is unsettled, and consequently also with other countries. There is a lack of cheap rice, the staple food of the people.

As a result of the war, the value of imports from the United Kingdom, alrcady reduced by the tariff policy of 
the United States, in the Philippines, to something over $10,000,000$ pesos, has fallen off nearly 50 per cent. In 1918 the value of imports from the United Kingdom was only $5,528,814$ pesos. Before the war, imports from the United Kingdom consisted mainly of textile goods of finer counts, wider widths, and high quality, earthenware, some brass manufactures, copper sheets, machinery, paints and shipchandlery, biscuits and jams, some leather goods and heavy ehemicals and crude drugs. During the war, export restrictions, high freights, dear materials and heavy taxes, all contributed to lessen the quantity of goods imported from the United Kingdom. With a return to normal conditions, provided there is a material decline in costs, it is thought that the trade of the United Kingdom will revive.

The American in the Philippines has not feared to tackle that most difficult of all difficult questions in the Orient involving religion, and the settlement of the issues relative to the Friars' lands seems to meet with general satisfaction among people of various classes.

There has also been founded and equipped the University of the Philippines, favorably comparing with institutions of this order in the Orient. There have been gathered one-half million children into schools that are under supervision. One finds a first-class Young Men's Christian Association system, together with a brace of missionary aetivities, including hostels and schools for both boys and girls. The Americans have also begun and have accomplished much in the standardization of English as a medium of educational poliey in the Orient.

One sees here advances in craftsmanship and trade schools that may be studied with profit by both Americans and Europeans, being examples of enterprising genius, unique in this branch of educational training. For days, under the conduct of trained experts having in eharge the manual training and trades schools, I visited the institutions which are laying the permanent foundations for future success in the Philippines. Designing, carpentry, machine shops, 
basket making and domestic science are carried on under the most modern circumstances of machinery and method. One sces almost every practical art, from the dexterous stripping of the Tipon-tipon palm, to be converted into the weaving of a lunch basket, to the manufacture of an automobile in which the educational officials ride in their tours of inspection.

The educational creed of the Islands is epitomized in the words of Lowell, which the educational director has placed as a foreword in his Philippine Craftsman and incarnated in his working policy:

No man is born into the world whose work is not born with him; there is always work and tools to work withal, for those who will; and blessed are the horny hands of toil.

Although the American occupation of the Philippines has brought about advances that are revolutionary in their beneficial influence and sweep, the problems of the Islands are ever present in the minds of the foreigners who are either temporarily or permanently finding here their home.

One of these problems arises from the fact that the islands are rich in timber lands, and also contain fine possibilities for the growing of such products as rice, cocoanuts, tobacco and other tropical crops, but that, as yet American capital has found investment in these lines to be attended with considerable risk.

I talked with a group of Americans who had made a trip to the Philippines especially for the purpose of investing in cocoanut plantations, but upon hearing of the impediments attendant upon this tropical industry, the discovery and preparation of the soil, the securing of the right exposure, the labor of preparing copra and many other difficulties connected therewith, abandoned the idea as impracticable.

A further large problem facing prospective investors is the problem of labor. If the Chinese could be employed in the Islands, many of the doubtful questions of tropical 
cultivation undoubtedly would be solved. Filipino labor has not proved especially profitable, though modern machinery is slowly being utilized to advantage. The Chinese, howcver, are at home upon Eastern land, and have already turned the tide of industry in the Malay Peninsula and Java. On the other hand, it is thought, and probably it is true, that the introduction of Chinese labor in the Philippines would work to the decided disadvantage of the Filipino, if it did not entirely deprive him of a place in the smaller industries of the islands.

An ever-present difficulty is that of legislating at home for a people who live nearly 12,000 miles away. There is in America, and naturally enough, no such general knowledge, and no such settled administrative policy governing colonies, as that which is found connecting the British Parliament with its Asiatic dependencies. The poliey of governing India, for example, is in the main a generally conceded and settled one, going on steadily like the English Constitution, more or less regardless of viceroys and ehanging home ministries.

In the Philippines, contrariwise, the shifting of party administrations at home are inclined to be followed by disturbed and uncertain conditions there.

My visit to these islands occurred at a time of such unrest, due not only to unknown or undetermined plans as regards the best things for these islands, but also one is bound to believe, to the ignorance of legislators concerning Asiatic situations and peoples. One of the first pieces of news that greeted me upon arrival at Manila, was the dubious intelligence that the Government revenues had been falling off five hundred thousand pesos a month for several months, and the reason given by the officials was that a new political administration at home, with a somewhat different attitude toward the self-government of the islands, was throwing out of balance the whole system of trade and business conditions. Without going into the merits or demerits of the case, one could easily see that all departments were being affected by the change. 
The educational officials and directors were feeling the insecurity of trying to work out advance policies that had been made to cover a period of years. I talked with many Filipino politicians also, whose views varied, to be sure, as widely as most politicians' views vary in both the East and the West, but regarding one question all were more or less agreed-that question was, "the Philippines for the Filipinos." The attitude was not unlike that which one finds to-day in the new nationalism of Egypt, India, and in fact, in the political attitude of every subject race in the Orient.

One prominent native official declared:

It (self-government) may come to our islands in eight months; it may linger for a year or more; but our people about Manila at least are thrilled with the expectation of some form of independent self-control of the country on the part of the native inhabitants.

One who has not been "on the ground" cannot possibly conceive of the changes in sentiment that can be brought about amongst an Oriental people by that which may seem to be, at the base of home government, a mere reiteration of policy. No one, I am sure, if he had not seen it with his own eycs, could appreciate the precarious unsettledness in which the discussions in Congress regarding the Jones bill threw the foreign as well as native population in the Philippines.

There are many misunderstandings growing out of distance and the contrasts between the mental point of view of America and Asia, but the problem which is always uppermost both in the United States and in these islands is associated with the self-independence of these people, whether or when it should come and by what means it should be brought about. We are told that a certain diplomat who was closely associated with President McKinley in 1898, stated that the Philippines were annexed because no one could suggest any other feasible way of dealing with them. 
As far as one could learn, from association with those who have reason to know most accurately the temper and life of these people, there is but one opinion at present amongst most of the officials and American colonists in the islands. This opinion is to the effect that for the present, and for a long time to come, the United States must remain at the helm of government in order to save the islanders from themselves or to obviate an exchange in the islands, of govelnment by the United States, to government by some European nation, or by Japan. There is little doubt but that the wilder tribes, which are by no means peaceful as frequent outbreaks prove, because of their powerful fighting qualities would overthrow any Filipino government that might be left unprotected by Uncle Sam's troops, making intervention by some stronger power a veritable necessity.

Those who have contrasted the character and ability of the East Indians, for example, and their ability to rule themselves, with the heterogeneous views and capabilities of these island children, are generally united in their opinion that the intelligent Indian should be given selfgovernment ahead of the Filipino. On the contrary, the American Govermment is based on a conception of freedom in a way that British government and colonization cannot fully understand or sympathetically appreciate. The United States, to be consistent, therefore, must take the position that the general principles which control at home must be given, sooner or later, the opportunity to express themselves in each of its tributary states or dependencics. In other words, the Philippines furnish the somewhat unique meeting ground between ideal theories and practical polities. Here we have a melting-pot in which are seething the diverse problems known in a half dozen Asiatic areas, combined with the multitude of western administrative republican ideas and forces which have not yet been brought to full fruition in Amcrica.

The Federal official finds himself more or less distracted between his practical desire to follow England with an 
iron hand of authoritative rulership, and his own inherent temperament and training which would give the "square deal" of statehood to these people. Add to thesc conflicting sentiments a constant stirring of the caldron by the ever changing partisan polities at home, and you have the political dilemma of the Philippine Islands.

The end is not yet, and in fact the end cannot be prophesied with any accuracy. In the way of the Englishman, the best we seem to be able to do at present is to play the game of civilizing and modernizing in accordance with the plan already so wisely and successfully inaugurated, and trust in the "muddling through" idea, assisted by developments which at present can only be guessed. Of one thing we are sure-the United States has put its hand to the plow and it cannot turn back. In all probability there are more problems ahead than those which have already been encountered. It is a great job, and a fine one, but when it is eventually accomplished, one can have little doubt but that the islander of these southern tropical seas will have grown to somewhat of the stature and the independent individuality of the freeborn American, and that a new sphere of world trade shall have been opened. 


\section{CHAPTER XIX}

\section{AMERICAN TRADE IN INDIA}

We are accustomed to think of the Oriental as a passive, slow moving, dreamy creature, satisfied with his own antiquity, standing aloof from the modern world with its aggressive desires and achievements, turning his gaze into his soul.

It is, therefore, with genuine surprise that the Westerner, who to-day sails "East of Suez" finds virtually the entire East coming with a rush into the Western world.

While riding on the back of a camel on the edge of the Sahara desert not far from old Biskra, I heard a whirring overhead, and looking up I saw an aëroplane of the French army, wheeling over the black tents of the Bedouins. The Moslem pilgrims are no longer obliged to go to Mecea by eamel caravan, but are whirled there by express trains, while the electric light is said to burn above the tomb of the Mohammedan prophet at Medina.

I found the Gaekwar of Baroda in India installing einematograph machines through the rural sections of the native state of Baroda, and going incognito to sit in a back seat and hear the expressions of the Indian cultivators, as they witnessed the modern methods of farming on the prairies of Kansas and Nebraska.

China is not behind. The land which we have so long comnected with an antediluvian people, remote from our civilization as in the days of Marco Polo, has now established a parliament, accepted Western business methods in many port eities, developed reformers, revolutionized her school system and even reports the doings of suffragettes in Peking. 
Japan in her victorious conflict with Russia was very largely responsible in starting this change which has reached the Orient from Tokyo to Morocco, and Japanese progress in all forms of enlightenment is the order of the day. A single intimation of this is revealed in the fact that 98 per cent of the male population and 97 per cent of the women of Japan ean read and write.

Among all Oriental countries, India is perhaps farthest away from the United States as far as intimate knowledge of conditions in that great country is concerned. Here is a land of marvelous opportunity with a population of $315,000,000$-as large as Europe without Russia, and increasing at the rate of 250,000 per month. The land is a melting pot of racial mixture, there being 41 races and 21 languages and dialects in every day use. Its annual commerce with Great Britain alone amounted in normal times before the war to more than $\$ 400,000,000$.

India has over 40,000 miles of railroad, which earry yearly $350,000,000$ passengers, and $65,000,000$ tons of goods and merchandise. Here modernity is at work, as evidence is found in India's big eities equipped with modern conveniences, street railways, telegraph, telephone, electricity, sanitation, hotels and commercial houses, and with a slow but certain acceptance of the chief business and educational appliances of the Western world.

All this vast land is ruled by Great Britain, and under pre-war conditions, with not more than 100,000 British troops and about 1500 civil servants and school teachers.

Political unrest has been evidenced in India in different sections and this probably is inevitable amongst a people ruled over by another nation. The eoncessions to East Indians given by Great Britain in the Legislative Councils and Assemblies, and the willingness shown to share more and more the Government with the natives has proved the wisdom of the British colonizer. There has been lately a rather serious diffieulty in the Punjab, brought about by what seems on the surface to be a somewhat radical move on the part of a British military officer in firing into a 
group of natives who were suspected of revolutionary and disloyal tendeneies. In this, as in other East Indian troubles, there will be doubtless a settlement in which the native population will gain somewhat more of consideration on the part of the British.

The war has had its results in India and among them have been the new trade routes opened and the export and import activities by which the United States has revealed her interest in this old country.

Previous to 1914, despite the presence of our diplomatic and consular offices in that country, an American traveling in that part of the world would first get the impression that Indian trade was for the Briton only. In the decade before the World War, however, German commeree and propaganda increased notably in India.

Since the war the United States and Japan have been coming to the front in Indian trade. According to a recent London report the place of the Central Powers has been taken by the United States so far as iron and steel, machinery, hardware and instruments are concerned. Japan has taken trade heretofore held by the Central Powers in such artieles as electrieal aceessories, eopper, paper, glassware, textiles, beer and clothing. The bazaar trade in cheap, showy goods has been largely captured by Japan.

The primary reason for the increased shipments of American manufactured goods to India has been the inability of the established British exporters to supply the market owing to war conditions. Our improved shipping facilities have contributed largely to the expansion.

There is no doubt but that American eompetition in India has come to stay. A determined American effort is being made to seeure a large share of the trade of this valuable market in steel and steel work, machinery of all kinds, including machine tools, mill stores and hardware, canned provisions, motor cars, lorries and eycles, and lumber.

These new trade conditions in India are brought out 
rather explicitly in a blue-book presented to the British Parliament in December last by T. M. Ainscough, British Trade Commissioner in India. It is a work intended to arouse Britishers relative to the need of adopting new methods and giving more thoroughgoing attention to their trade interests in this vast Empire. We quote briefly from this report:

Before the war there were practically no American merchant importers of high standing in India. The last few years, however, have witnessed the opening of a few large firms which are already doing a considerable trade. For instance the United States Steel Products Export Company and the branches of Grace Brothers have established themselves in India. The latter are already doing business on a large scale, both as regards imports, exports, and the management of local industries. Much greater facilities than in the past are being given by American banks and shipping companies to the export trade, and every effort is being made to study the requirements of the Indian market in a most remarkable way. In the motor car trade for instance, the policy of standardization of cars and spare parts, the personal attention given to importers by representatives and mechanics, and the allowances for advertising and general propaganda work have had a most favorable effect on the sales. American houses are often much more generous in their agency terms than their United Kingdom rivals. In the provision trade the type of container used, the attractive labels and get-up, and the general care given to packing has gone a long way to account for the phenomenal expansion in the business.

The broad geveral fact is that the circumstances of the War and the relative measure of exhaustion of Great Britain after four years of conflict, and of the United States, with a comparatively brief experience as a combatant, gave the latter a greater advantage in industrial and commercial activity, of which she has taken the fullest opportunity in the Indian market. Her competition there has come to stay. It is impossible, says Mr. Ainscough, even to estimate the probable future success of American firms when the usual United Kingdom suppliers, now hampered by labor troubles and difficulties of all kinds, are in a position to quote normal prices and deliveries, and when the usual channels of trade are fully opened up. 
The Trade Commissioner sums up the more immediate lesson of the situation from the British point of view:

Many United Kingdom makers and export houses, prior to 1914, considered that it was a waste of time and money to leave London, as they were able to seeure all the orders they wanted from the purchasing agent at home. This policy, although not progressive, was understandable so long as we retained the virtual monopoly of the market. India to-day must be considered as a highly competitive market, and requires to be treated with as great and painstaking attention as any other market where wo may be struggling to secure a fair share of the trade. Assuming that our industrialists are in a position to cinote competitive qualities, prices and deliveries, the only way successfully to meet American competition is to be represented actively by a trained staff in India, whether by the maintenance of the exporter's' own branches and distributing organization, or by the employment of energetic agents aided by salesmen and experts from the home works.

The large expansion of Japanese activity in India has been principally through travelers and business men from the Island Empire of the Far East. In 1911 there were only 32 male Japanese in India. To-day the number exceeds 2000. One finds Japanese retail stores in nearly every large town in India and even in the most remote parts of the countries Japanese workers will be found. The Japanese are taking a prominent position as general distributors in India of imports from all over the world and as shippers of Indian produce. In spite of complaints on the part of the people of India regarding the Japanese methods and practices, sueh as mistakes in drafts and documents, late arrivals of goods, and complaints concerning the quality of second shipments, the Japanese organization abroad works as one unit and is devoted to the national Japancse cause. This national team play assists in keeping out eompeting interests.

It is thought that Japanese competition with Great Britain is likely to be most permanent and persistent in Great Britain's staple trade in India, that of eotton 
yarns and piece goods. The scale of working expenses of the Japanese, together with their individual industry presents a strong competitive element, while their willingness to live in remote sections, under conditions impossible to an Anglo-Saxon, and their understanding of the subtleties of the Oriental mind, make the Japanese formidable rivals of Great Britain and the United States in connection with Indian business.

Relative to the conditions which Britishers as well as United States traders must meet in India, the following paragraph quoted from the British Trade Commissioner in India is illuminating:

There is a tendency among many of our British produce firms to take the line of least resistance. The social amenities are pleasanter at the ports, and the necessity of keeping a vigilant eye on conditions, prospects, and prices in the producing districts was not apparent in the past. In consequence, they (the British) have usually confined their activities to Calcutta, Bombay, Karachi, and Madras, and have relied upon their banians and brokers to keep them informed of local conditions up country. The result is that, speaking generally, the Continental firms, with their own depots and European traveling agents in the distriets, are infinitely better informed on crop prospects and ean make their own estimates with a reasonable degree of accuracy. The same scientific methods are now being adopted by the Japanese- there are only two remedies open to the British houses. They must either perfect their own organization, discard the old ideas and methods, and make a bid for the trade in a manner in kecping with the times, or they should relinquish the business. Up to the date of writing their sole efforts seem to have been directed to appeals to Government through the Chambers of Commerce for restriction on foreign competition, so that they might still go on undisturbed in the old inefficient haphazard way.

That the American manufacturer and trader may get an idea of the lines along which East Indian trade is now being developed particularly, we quote from the Commerce Report of December 2d, Bureau of Foreign and Domestic 
Commerce, for four months ending July, 1919, as compared with the corresponding period of the preceding year.

The quantity of cotton piece goods imported into India decreased by $218,000,000$ yards or 50 per cent to $219,000,000$ yards and the value was less by 44 per cent. The value of cotton twist and yarn imported decreased by $\$ 6,156,123$ to $\$ 2,996,791$, of articles imported by post by $\$ 2,342,084$, of woolen piece goods by $\$ 1,069,332$, of salt by $\$ 1,745,452$, of raw cotton by $\$ 1,593,941$, and of matches by $\$ 924,960$.

Imports of wheat increased by $\$ 6,798,177$, sugar 16 DS and above by $\$ 534,341$, kerosene oil by $\$ 3,129,160$, lubricating oils by $\$ 1,671,165$, raw silk by $\$ 803,946$, motor ears and motor cycles by $\$ 2,139,313$, hardware by $\$ 1,465,790$, electrical machinery by $\$ 1,286,378$, electrical instruments by $\$ 613,503$, jute mill machinery by $\$ 916,631$, sheets and plates (iron or steel) by $\$ 3,729,362$, and silk piece goods by $\$ 1,222,789$.

Under exports the quantity of rice not in the liusk shipped during the four months decreased by 692,574 tons to 155,711 tons, and the value by $\$ 21,130,668$ to $\$ 7,588,172$, while wheat showed a decrease of 269,899 tons to 2701 tons in quantity and of $\$ 11$,881,772 to $\$ 210,557$ in value. The quantity of raw jute exported showed a decrease of 20,460 tons or nearly 15 per cent.

The value of coffee exported increased by $\$ 2,169,810$, of cotton twist by $\$ 10,612,215$, of piece goods by $\$ 5,172,765$, of raw hides by $\$ 7,414,924$, of raw skins by $\$ 10,925,294$, of skins (tanned) by $\$ 4,635,504$, of hides (tanned) by $\$ 3,821,500$, and of seeds by $\$ 24,588,153$, while the value of barley decreased by $\$ 4,940,471$, of grain and maize by $\$ 5,993,257$, of castor seed by $\$ 1,799,632$, of black tea by $\$ 1,709,115$, of gunny cloth by $\$ 6,744,816$, and of gunny bags by $\$ 2,245,728$.

In order to break into successful trade with an Oricntal nation like India, there are two things to be consideredthe commercial and the mental qualifications. The latter is no less important than the knowledge of products and the export and import markets suggested above.

What kind of people inhabit this vast peninsula? What are their needs and points of view? How do they like to do business? What is the first thing for the manufacturer 
or exporter to undertake? These are questions which the American foreign trader must be prepared to answer by actual knowledge if he expects to do more than make a feint of trading with India. It is no easy task to get the mental view point of the Oriental. These people are our antipodes in more senses than one. You may think you know an Oriental and be convinced that at last you have really discovered him when suddenly the next one you meet reveals characteristics that upset utterly all your previous calculations and estimates. The only way to be quite certain that you know an East Indian is not to meet another one. There are things, however, that we ean know and important things for the trader to consider.

He must remember that approximately two-thirds of the population of India are Hindus and that the other one-third approximately are Mohammedans. Before living long in India he will find that customs differ between these two religious sects, and religion enters into trade as well as into every department of East Indian life. It would be an anachronism, for example, for a Hindu whose religion has taught him that a cow was sacred, to have anything to do with the trade of hides and skins. Therefore, Mohammedans and not Hindus are engaged in this latter industry. Among the Hindus a shoemaker occupies one of the lowest positions in the social scale. The Mohammedan, on the other hand, has no such prejudices, but the rules of the Koran against drinking spirituous liquors and the attitude toward social questions have to be considered.

It must be remembered also that at the summit of East Indian society are educated and cultivated men, many of whom are getting a voice politically in the legislative assemblies and otherwise. Below these East Indians of intelligence and culture, without much of a middle class, are the ignorant and in many cases impoverished millions, over-ridden and kept down by their caste system and as impotent for great leadership as are the South American cholos and Andean Indians, or the coolies of China. In this melting-pot also must be noted the Eurasians and 
Anglo-Indians, racial strains produced by mixed marriages between Orientals and Occidentals.

Then there are the Parsee merchants who have been ealled the "Jews of India." The American trader" who has come in eontact with these latter business men in Caleutta or Bombay has obtained a new idea of the ability of the East Indian to do business along practical and successful lines.

Methods of trade here, as in all other countries where it is "always afternoon," must be suited to the climate as well as to the customs of the people.

The following description is given by one of the representatives of Grace Bros. (India), Ltd., eoneerning the purchase of hides and skins in this country.

The hides and skins come into the bazaar from the railroad station in bundles, all assortments and classes mixed up, and although the buyer is permitted to assort the hides before they are bought, it is most difficult to bring the ideas of the seller down to the proper market level, and one has to talk for hours and hours in Hindustani till the seller is convinced that he cannot get another cent out of you. Talking is a great stunt in India, and it is marvelous how much time is wasted over itand in this business it is the head Munshi, who has to do a lot of the talking and prepare the way for his 'Sahib' (Sahib is the Hindustani title given to a European) who has neither the time nor the inclination to discuss what would have happened ifetc. This diseussion must take place before business commences and the Head Munshi is very useful in this respect; it is furthermore a part of the latter's duty to make the seller understand that it is not at all likely that his Salib will buy the hides or skins in question, but if the unexpected should happen which would mean that the Sahil is in a 'benevolent' mood at that moment, the seller may consider himself very fortunate.

After all these preparations have been made the Sahib is asked to appear, and when he arrives he is welcomed by the 'Arrathdar' as a long lost brother, and is bombarded with questions by this 'gentleman as to his own health, and that of his wife (he may not necessarily have one) and family, although the parties may have separated the day before as deadly enemies owing to the impossibility of being able to come to terms.

A seat is offered to the buyer, but it would be fatal for him 
to commence talking 'shop' straight away, as in all probability it would increase the ideas of the seller by at least 10 per cent, therefore, the Sahib has to wait till the 'Arrathdar' is ready to discuss the business in hand, and as the same is generally rather slow to take up the subject, a good amount of time is wasted. When eventually one does get down to business and the bargaining commences, 'Allah' (all hide dealers are Mohammedans) is brought up to witness that a frightful amount of money is being lost, and the other side regrets this immensely, but on the other hand cannot help it as the Sahib will lose an equal amount or more; neither side believes a word of what is being said, but this is all part of the 'game.' Eventually, if the two parties come to terms, the departure of the Sahib takes places in the same ceremonious way as he arrived, and the 'Arrathdar' finally shakes hands with him and wishes him all sorts of good things; if, on the other hand, business does not result, the parting is not at all friendly, and the buyer has to wait till the next day, before he can approach the 'arrathdar' on the same subject again.

A few rules for the American foreign trader or salesman doing business in India are suggested:

First: Don't try to hurry the East Indian! Kipling's verse is apropos:

Now it is not good for the Christian's health

To hustle the Aryan brown,

For the Christian riles

And the Aryan smiles

And he weareth the Christian down;

And the end of the fight

Is a tombstone white

With the name of the late deceased,

And the epitaph drear;

"A fool lies here

Who tried to hustle the East."

American "hustle" and "efficiency" with the slogan "Do it now" is about as useless as trying to pour water in a frog's face to drown it, when applied to the methods of officials in the Far East. One day a bustling, energetic American eame into the office of the American Consul at 
Shanghai, and announced that he was a representative of one of the big locomotive works in America, and had come out to finish some contracts with the Chinese Imperial Railway. He found he could get an introduction to the General Manager of the Railways through the Consul, and even that had dragged on for more time than he thought necessary. He had booked his passage home by a steamer leaving Shanghai in two weeks, and expected to fill his contracts and see a little of Clina in the meantime. When the Consul told him it was impossible to sail by that steamer, he was seornful, then sarcastic. "You've been here too long, Consul, you have forgotten how we do things back home. I'm an American and I do business in the American way. I'll have those contracts in my pocket and sail on the Manchuria."

The Consul smiled and said "Well-you are going to meet His Excellency to-day. Stop in on your way back and tell me what you have done."

The optimistic American went to his appointment and in about three hours a rather dejected, sullen man appeared in the doorway of the Consul's office. "Well," said the Consul, "everything finished, I presume. Got the contracts, of course, sure you haven't built the road already?"

The man chewed his unlit eigar for a moment, then he laughed, "Got nothing," he said, "except an invitation to dinner three weeks from to-morrow night!"

The man was in Shanghai eleven months.

Second: Remember that the East Indians of the upper castes particularly are not lacking in intelligence. The Bengali-Brahmins are probably not surpassed by any nationality in intellectuality.

Third: Leave your religious prejudices behind when you enter into trade and commercial relations with India.

Fourth: Get into touch with some American concern that is doing business in India and save yourself many initial mistakes. For example, although 85 per cent of the Indian population is engaged in agrieulture, the problems of farm machinery and the fertilization of land are very 
great ones. This is due in part to the conservatism of the inland cultivators who are slow to change, and also in certain parts of India to the small farms which do not lend themselves to modern implements especially such things as steam-plows, tractors, etc. Poverty of the Indian farmer is also a handicap to this trade. The fertilizing problem is made difficult because the manure in this eountry is used largely, and necessarily so, for fuel.

Fifth: Have patience and be willing to lay firm foundations for the future. In India there seems to be a settled conviction that there is unlimited time for Providence to accomplish its purposes.

It is estimated that the United States is supplying from ten to twelve per cent of the imports of India. Before the war the United States supplied only 2.6 per cent.

The exports from the United States in 1920 to India were practically ten times as much in value as in the year immediately preceding the war, the total value of our exports to India having grown from $\$ 10,379,000$ in 1914 , to $\$ 99,828,000$ in 1920 , and while the 1921 exports to that country show a decline, as they do to all other parts of the world, they will be for the current year approximately six times as much as in the year immediately preceding the war.

It is well for the American trader to note that India is awakening rapidly both as to economic and material progress. The urge of economic necessity is upon her. The war has helped to break out a window for India into the wide world. She will never be content again to live merely on the shores of the Ganges. The United States has products and manufactures India needs and must have. Now is the acceptable time to enter Indian markets. For the study of India and India's wants only intelligent agents should be sent out; only men who can adapt themselves to customs, strange and often mysterious. Already the United States has a foothold in sections of the East Indian Empire. The future of our trade depends upon one's knowing and following the rules of this foreign trade game. 


\section{CHAPTER XX}

\section{CAN TRADE WESTERNIZE ASIA?}

The East bowed low before the blast,

In patient, deep disdain;

She let the legions thunder past,

And plunged in thought again.-Matthew Arnold.

Foreign trade has interested itself in the Orient because the majority of the human race dwells in Asia, the largest of the continents. Asia is numerically tremendous with her nine hundred millions of population, four times the population of Europe, forty-one times the size of France and the sphere of activity of more than half the population of the globe. Although Asia has never been known as containing warrior races, it is conservatively estimated that she can muster one hundred millions of fighting men, while the warrior nations of India alone outnumber those of the combined nations who speak English.

The strategic significance in the history and trade of nations of the Asiatic races, is not generally realized. Asia's struggle with Europe has lasted two thousand years and has been the binding thread of history; her trade with Europe has been the foundation of commerce; her philosophic thought has been the basis of all Western religion, and the charm and the spell of her antipodal customs have been the wonder of every Occidental student or traveler.

In spite of these facts, it is notable that the fusion of races, Asiatic and European, has never occurred; the great continent of Asia has never vitally associated its creeds and customs with those of the West; its currents of thought, 
like its streams of blood, have not flowed together to any considerable extent in a common consanguinity with those of the Occident, and many of the most profound students of the Orient believe, that in the deepest sense, there never will exist absolute comity between the Asiatic and the European or the American. Meredith Townsend in presenting conclusions derived from a long life devoted to the study of relationships between Asia and Europe says:

Asia, though it yields from time to time to the sudden impact from Europe as water yields to a ship, always flows back after a ripple more or less drawn out, without having been apparently affected.

As one travels from country to country among those people who profess as religions the creed of Islam, of Buddha, Brahma, Confucius, Zoroaster or Shinto, realizing meanwhile the seemingly inexhaustible force of these faiths to grip and control Orientals, he also realizes how little these vast religions appeal to the Western mind, and how they seem to be at home in the tropical rather than in the temperate zones.

Let the foreigner come into contact with the Eastern mind in matters of trade, let him try to match his intuitive processes in diplomacy or politics with those of the sons of the Orient, and he very soon becomes conscious of certain inherent and incurable differences, inevitably separating him mentally from his Eastern neighbor. During my first tour in the Orient twelve years ago, I met Occidentals who seemed to be well-nigh certain that they had reached the solution of certain racial and international problems vexing the best minds of Western aliens in Oriental lands.

During a more recent tour through Asia, I met again some of these same persons who tell me that their former certainty has been dissipated and destroyed with further years of contact with Asiatics. As one of these persons suggested, a Westerner can only be sure of the conclusions of to-day; to-morrow is likely to bring him a new set of 
strange and contradictory experiences throwing all of yesterday's conclusions out of balance.

It is not merely a kindergarten fancy to state that Oriental populations, from the point of view of the Occidental at least, are walking on their heads. In almost everything, Asiatics are our opposites. Whatever you say about anything Eastern, remember that from some other angle of vision the contrary could be truthfully stated.

A former British Ambassador to Constantinople wrote:

When you wish to know what a Turkish official is likely to do, first consider what it would be to his interest to do, next what any other man would do under similar circumstances, and thirdly, what every one expects him to do. When you have ascertained these, you are so far advanced in your road that you may be perfectly certain that he will not adopt any of these courses.

One soon discovers that his Asiatic impressions depend largely upon the people whom he meets. I made one trip around the world in which I met many Protestant and Catholic missionaries, European and American, and talked and lived with European officials and Western men of business. As my conclusions, drawn from this experience, coincided in general with many books which I had read upon travel and official history written by Europeans and the treatises and reports of missionaries, I somewhat naturally decided that my point of view was in general a correct one, relative to the character and progress of Asiatic peoples.

As a balance to these impressions on another Eastern trip I traveled and lived almost exclusively with the native peoples of North Africa, Egypt (and Egypt is peculiarly Oriental), India, Burma, the Malay States, China, Japan, and had also some association with the inhabitants of the Philippines and the islands of the southern seas. To my surprise and often to my puzzled bewilderment, I found myself inevitably drawn to conclusions quite different from those I had previously formed. 
While I have never met with more lavish hospitality or more intelligent penetration or more decided social, religious and political convictions than those I encountered among these Asiatic folk, I have been repeatedly and constantly aware of something radically distinct, something intangibly and irremediably different from that which my Western birth, education and environment have given me. I have felt that, even if I had accepted the creed of the Moslem or the Hindu or the Confucianist, this barrier would not have been removed.

The sense has not always been present, to be sure. At times one seems to forget entirely his geographical and racial partitions in converse with men of light and leading who are as fully aequainted with the history and movements of nations, as those of the highly educated classes of the West. But when one follows these same congenial and modern Asiaties into their homes or to their places of worship, or comes upon them suddenly when they are off guard, surrounded by their own people or friends, this mysterious lack of comity again arises.

One finds himself asking: Can Asia ever become really Westemized? What is to be the effect of our new trade contacts? Is there not some inherent dissimilarity between the West and the East which forever forbids the one permanently to mix with or to conquer the other? Can the training in commerce and in the arts and sciences of the West cure these prejudices of color and creed, these natural and temperamental incongruities; or has Providence rooted deeply and inextricably distinet laws of the mind and the spirit in these truly distinet continents, so deeply, so inextricably that all human effort will appeal in vain for their real union?

National and racial contrasts are among the most real things one feels as he delves into the life and history of the Asiatics.

The artistic ability of the Oriental is unquestioned. Asiaties have built the Taj. and the Alhambra; they have constructed the marvelous temples of Buddhism; they have 
built the graceful towers and the temples and mosques of Cairo and Benares; they are responsible for the towers of Nanking and the palaces of the Shoguns. Chinese porcelain is the best of its kind in the world, and the literary and the artistic ability of the Tagores of India can be duplicated in many a circle of India and Japan. One will not find in Western lands the equal of such work as the Damascus blade, the gold chains of Trichinopoli, or the black wood carving of the Middle Kingdom.

Yet in the conquest of nature, Asia is behind Europe and Western nations. Living for centuries above great mines of iron, coal, tin and platinum, she has been content to shiver about her tiny braziers or her fires of cowdung, to plow with erooked sticks, to use gourds for carrying receptacles and to make her homes in temporary dwellings of mud and straw. In the science of medicine, in machinery, in scientific discovery and in the conquering of natural resources generally, Asia for generations has been tried in the balance and has been found wanting.

From the point of view of morals also, the Asiatic is different from the European and, from the latter's point of view, is unadvanced. He is at times a creature of superstition. The "evil eye" of Egypt has a thousand counterparts in a thousand Asiatic communities. The Oriental is not moral in the sense known in the West. He often practices falsehood, and often sees no evil in so doing, save as falsehood is objectless or unsuccessful.

$\mathrm{He}$ is more truly a hero worshiper than the Westemer. Confucius, who did not claim to be a prophet, has molded the thought of vaster populations than any other, save that of the Oriental, Jesus of Nazareth, while the name of Mahomet is a compelling idea to two hundred and twenty millions of the earth's inhabitants.

Asia, moreover, differs from Europe in being a land of contented acquiescence rather than one of aggressive acquisition. Despite hunger and famine and pestilence and sword, Asia has pursued her way unchangingly until the present, indifferent alike to misfortune, wars and death. 
Save in astronomy, the East has made small contribution to science. She has produced no great historians, and until recently she has had few great travelers and investigators, and has been accustomed to give small credence to the accounts of tourists and traders relative to conditions in foreign lands.

But as the originators of philosophy regarding relations between the seen and the unseen world, the whole earth has gone to school to Asia. Whence? Whither? Why? These are the questions which have been the subject matter of Asia's deepest thought. She has rested her great religions like Hinduism and Buddhism upon the deep philosophies of the mind and spirit.

In the doctrine of reincarnation, Asiatic religion has attacked and solved for itself, at least, the most vexing problem of the world, the problem of the origin and reason of evil, and the apparent uneven justice in the world presided over by a just God, the problem that no Western race has satisfactorily settled for the majority of its adherents.

To the Westerner, this doctrine is faulty in many of its phases; it is difficult to secure adequate evidence and the man of the West demands objective as well as subjective evidence for his truth. Nevertleeless, the faith has been the means of saving millions of Asiatics from irreligion and the atheism which at various times has spread over Europe. Who can, with honesty, utterly deride a creed that acts as a bridge from doubt to faith for millions, even though the ereed may seem at times a tissue of superstitions and far from perfect in its working.

The Moslem, while he does not accept the theory of incarnation, finds for himself an adequate explanation of the evil of the universe in the idea that "Allah wills." Fatalistic it may seem, but it has held the faithful with a mighty grip, defying all attempts at conversion, and has made Islam the "missionary's despair."

The weakness of the Asiatic's religion lies in his lack of emphasis upon ethics and social responsibility. He cares 
little, in faet, for the great thought of the brotherhood of man. He is strietly a religious individualist. Outside of his family or clan or easte into whieh he is religiously bound, he has little appreciation of an obligation to his neighbor. It is the absenee of good Samaritanism that has eaused Asia untold conflicts, murders, wars and turmoil. Although we may say that the West has not lived up to the seeond great commandment, we must also add that the West believes that it ought to live up to it, while the East disregards it or treats it with contempt.

The fifth commandment, however, is obeyed in Asia as in no other part of the earth, the devotion of son to father being a kind of unwritten law instinetive in the Oriental's thought and heredity. Polygamy, on the other hand, is not considered adultery, the Moslem sanetioning it and the Hindu allowing it in cases when the first wife is ehildless. Asiaties are also free, or have been in the past quite free, from that gnawing and baneful covetousness of the West through their beliefs in the adjustments of society by a wise Providenee.

Although the Asiatic is accustomed to absolute anthority and bows to the will of a sovereign, as to a divine mandate, who may with impunity inflict death upon him, he has resisted for eenturies the encroachments of the West. Without being renowned as a marshaler of armies, Asia drove Rome from her Persian borders, and Alexander with his matehless political insight, coveting the disintegration of the Asiatie peoples, only suceeeded in founding a few Greek dynasties within Asiatie limits, and one will search in vain in Asia to-day for any eonsiderable Greek influence.

England has made deeper impress in Oriental Egypt and in India, the flower of the British Empire, than has any other European nation. But if England should leave the East to-morrow, her impression of many scores of colonizing years would hardly be deeper than the externals of modern civilization. In that part of Oriental thought and life, which to the Easterner is really the life-religion-England has said, "Hands off!" and in this real life of Asia she 
has attempted and has accomplished little or no change. Asia is not an aggressive conqueror, but by her power of passive resistance, springing out of her conviction of the difference of permanent idcals between herself and the West, she has proved a tremendous ability to reject her eonquerors and to survive them. Her spirit has been not unlike that of Socrates who could drink the hemlock and murmur triumphantly: "You can have my soul if you ean catch me." The West has never captured the soul of the East, and one doubts that she ever will.

From 700 to 1757, a thousand years and more, Asia was supremely Asiatic save for a small raid upon her borders by the Crusaders. Although it would seem that Great Britain has formed new precedents of control in Asia, a elose scrutiny of the facts reveal with what difficulty this control is being preserved. A few years before the opening of the World War, Lord Kitchener was rushed to Egypt to prevent imminent disaffection and disaster, and it is generally believed that only the presence of the late modern Pharaoh with his soldier's hand of iron preserved anything like quiet in the land of the Nile. The frequent recurrence of bomb throwing and assassinations in India give an inkling of what is seething below the surface where people are being ruled by an alien race. I was repeatedly told by English officials that a more extensive and careful secret service was now in vogue than ever before had been known in this land.

"You nevel know what is going to happen here," said a keen deputy eommissioner in the Central Provinces, a man who mixed with thousands of natives every month.

The Sepoy Rebellion of 1857 is always a shadow in the back of Tommy Atkins' mind, and its renewal is by no means a faneiful possibility. "All is quiet," says the home Government, but let a disinterested investigator travel and live in the native states of India, which compose such an influential part of India, that in the Sepoy Rebellion the loyalty of one State alone, Hyderabad, saved India for Britain, and what does he find? To be sure, outwardly 
all is calm and you will frequently find all kinds of meetings of memorial and appreciation to His Excelleney, the Viceroy, and in public a marked deference on the part of the Indian towards his British Raj. But when you meet the native in the privaey of his own home, if you are fortunate enough to induce him to break through the barries of language and nationality, you will find, almost invari. ably, something more akin to hate than to love for his British overlords. Said a vexed native Prince:

Do you know, I can hardly buy a pen or a sword for myself without asking the British Resident for permission.

The attitude of mind is not unlike that of Tewfik Pasha who, in the early days of the English occupation of Egypt, while watching a review of British troops said to one of his ministers:

Do you suppose I like this? I tell you I never see an English sentinel in my streets without longing to jump out of my carriage and strangle him with my own hands.

England has indeed been engaged in a great undertaking, and the result is becoming evident in a new material India and Egypt. But a people is not changed at heart by means of mechanical devices, whether they are railroads or irrigation, new markets, or Western buildings. As a nation thinketh in its heart, so is that nation. As Matthew Amold accurately has said:

By the soul only

The nation shall be great and free.

For the last few years we have been optimistically stating our beliefs in a new China. Behold a new Republic in an old Empire! Sweeping changes in every department of her life, young men in European bowlers and frock coats, Chinese women with unbound feet becoming interested in Western dressmaking and society, a new constitu- 
tion and a new set of politicians, closely resembling those made in America! In place of the old Literati examination stalls, modern school buildings, like those found in Europe and the United States and a new President of the Republic himself, although a Confucianist, appointing a day of prayer for China, asking especially the supplications of Christians for the New Republic. I was in China shortly after Doctor Sun stated that "the new Republic is the formal declaration of the will of the Chinese people." $\mathrm{He}$ told me of plans for trunk line railroads, bringing together the vast areas of this old awakened land. The dragon throne seemed rocking to its fall, the collapse of Manchu and Literati, the dissolving of Confucianism and the eustoms of centuries all passing as in the twinkling of an eye.

Yet those who knew China and who were aequainted with the treachery, the rapine, the piracy on the Kwang Tung coast, the assassinations and ineffectual delays of the new Parliament, those who came in daily contact with these half-Oceidentalized young politicians, realized the artificiality of such conquests of the East by the West. They knew that China had been accustomed to upheavals $s_{\text {g }}$ political as well as social, and that China regarder not the change of elothes nor the vicissitudes of rulers, as she went unheedingly throughout her vast secluded provinees, engrossed with the all-important and eternal question of daily rice. He who knows China appreciates that a nation, which has seen, unmoved, a Taiping Rebellion, devastating nine provinces and destroying forty millions of lives, a country which underwent four famines in the first half of the nineteenth eentury, costing the lives of forty-five millions of Chinese, is not easily and rapidly to be stirred out of its age-long placidity of habit and temper.

One keen discerner of Chinese life has said that:

The problem of China is one of economics, incurable either by religious teaching or by legislative formula.

In the shadow of all this uprising and seeming renaissance, the groundwork of rural, ancestor-worshiping Chinese mil- 
lions is inherently the same, as it would seem, yesterday, to-day and forever.

Here, as in India and Egypt, one finds increasingly encouraging signs of new and better conditions wrought by trade contacts in the Western world, by modern processes of thought and scientific and social machinery. But new constitutions and new buildings erumble beneath the steady and regular motions of centuries of habits and hereditary thought. China may take on the glad garments of the West; she may assume the language of the present, but her thought and her motives rise out of a vast repressive past. The real change is amazingly slow.

One then is driven repeatedly to the query, what does it mean to westernize Asia and who is capable of so gigantic a task?

Is America with our halting attempts at representative government, with our pipings of peace advocates, drowned by the roar of guns and armed conflicts with our neighbors? Torn by eivil strife between employers and employed, our municipal governments distracted between the crimes of officials and the threats of anarchism, can we consistently elevate the Republican idea in behalf of the Oriental? While over all our life in the West is the trail of luxury, of pleasure-seeking and utilitarian self-hood, shall we go to China or to India and have compelling power with a new social gospel?

Shall Europe so often at war with her brother nations, with her continental agnosticism and socialism, or England with her civic and industrial strifes and conflicts with her own divisions, teach the Asiatic peace and the secrets of higher powers, individual or national?

We cannot but ask at times as to how effective our religious message may be to Asia, the mother of our Western spiritual creeds. When the keen Oriental tells us that our religion has lost the spontaneous loyalty and glad devotion of our thinking classes, that our forms and rituals of professional religion are being upheld principally by women, that we are divided into a hundred camps and 
orders of faith, while outside the church, men are crowding our new civilization with multifold movements for uplift, social, charitable, and philanthropic, with all their evident duplication and often with the lack of a deep religious purpose-when the Oriental points out in answer to our derision of his Ganges worship, his lepers and his poverty, that all these efforts at reform in America are the symptoms of distress and moral and physical failure that ought to have been prevented by the essential religion we claim to represent, what answer shall we give?

Do we expect the keen-eyed scrutiny of the Oriental to overlook the real results of a Christian civilization as these results pass through his domains and are hurled before his eyes in the persons of unscrupulous foreign traders who laugh at his sacred things? A member of a high gentry family in China spent an afternoon in telling me of the bacchanalian orgies of Europeans and Americans in the port cities, of the acts of European business men under the guise of trade, the trivial example of tourists, the bickerings and divisions of rival Western faiths and the restricted laws of immigration, which excluded his people from America, through what he called the economic greed of the United States.

Let us not blame our missionaries, if we, by our works, make it too hard for them to influence the educated Easterner to accept our faith. Let us not wonder that Asia hesitates to displace the gods whose protection she knows, for those she knows not of, especially when those who worship them seem to deal in terms of gold and "things" rather than in the "fruits of the spirit."

When we appreciate that no American can hold land in Japan, and that foreign missionaries have been obliged to retire into honorary and advisory relation to the new selfguiding and new self-supporting churches, we are reminded of the fact that the most advanced portions of the Orient have not learned to trust the Occident. Indeed the distrust of anything in method or practice emanating from America is so pronounced and general in Japan that speakers and 
writers on education, politics and religion have been frequently warned to eliminate illustrations referring to Western and American ways of doing things, if they would have influence with their hearers. There was a time when it was said in England that no Britisher reads an American book; it is now a time in the Sunrise Kingdom when one might say that no one follows an American method, at least not without rigid, native modifications.

And yet the Orient, in self-preservation must be modernized, even westernized to a degree at least. For her, the future must bring the open, not the closed, door, to the Occident in trade, in education, in social and religious influence. The next quarter of a century promises changes and advances, economically, scientifically and politically, that may again change the balance of commercial and perhaps territorial conditions. Modernity has already passed through the portals of the East into the great Oriental cities. Although this present-day leaven of westcrnization has as yet worked but a small way into Asia - as the present unrest of Japan, the most advanced Eastern government is demonstrating-it will most surely continue to penetrate these vast continents until even the remotest fellaheen and Thibetan lama shall feel its irresistible impulse - and the Orient shall be changed, not suddenly, not in a generation, not by something revolutionary, nor finally by the aggressive forces of the westerner, but rather by the rising up of the awakened Orient herself to comprehend, to choose or to reject, as Japan, China and India have already begun to do.

When India accepts Christianity (said an astute American educator), as I believe she will accept it one day, it will be a Christianity with Hinduism, not Judaism, for her Old Testament.

In other words, in faith, as in trade and in everything else, permanent Oriental modernization will be fundamentally East, not West. The renewal of the Orient, for her own good and for the health of the nations, will grow 
out of the awakened, aetive brain and heart and hand of her own sons and daughters, and its roots will cling about the rock foundation of her own traditions, her own timelessness, her own temperament, and her own religion. The Oecident can help, though she ean never truly westernize the Orient-but the Orient can and will westernize herself.

Let the trader, therefore, going to the East to get business acquaint himself in advance with the inherent eharacteristies and age-long traditions dominating the Oriental. Lasting commeree with a foreign nation is based first of all upon clear comprehension of the nature of the people. Trade methods and merehandising arrangements can be adjusted properly only when this first step is taken. The exporter or manufaeturer who has learned that he cannot change Asia, her desires, her raeial requirements or her religion, at least not in generations, has taken the first step toward the trade modifications positively essential in westermizing the Orient. 


\section{CHAPTER XXI}

\section{OUR TRADE IN THE NEAR EAST}

There are good and sufficient reasons why traders and manufacturers of the United States should consider the possibilities and present opportunities for commerce in that extensive territory bordering upon the eastern Mediterranean, Black, Aegean and Red seas.

Out of this historic section of the earth, containing a population estimated at upwards of $25,000,000$, came the Phœnician and Tyrian shippers and traders, who at one time dominated the foreign commerce of the world, while the Golden Horm has been a seat of trade for 2600 years.

From this region also have sprung the religions that have spread over the European and western continents.

From the Near East, moreover, we have received some of the greatest streams of immigration-Greeks, Armenians, Syrians, and Jews-who have come to the United States to found homes and acquire eitizenship and prosperity, helping to link our country with the vast expanse which, excluding Arabia, includes upwards of 450,000 square miles of territorial area.

Into this borderland of the great Near Eastern sea we have sent our missionaries for more than a century and for all these years the name, America, has been known to the populations of the Near East as synonymous with modem education, with activities of charitable benevolence in times of distress, and with a disinterestedness as far as territorial aggression is concerned, that has made America less often suspected and more truly trusted than members of any other nationality. 
Our hospitals are to be found in every city in Turkey and our preachers and medical doctors in almost every village. Other nations have invested in these Near Eastern lands for gain, while we have poured into this region $\$ 20,000,000$ in founding schools and colleges, $\$ 40,000,000$ in feeding the hungry, and $\$ 50,000,000$ in affording missionary teaching, free medicine, and extending the borders of western civilized science and instruction.

All of this activity and giving have helped lay the foundations for a stable, modern commercial life, now about to give ample evidence of the value of these forerunners of national prosperity. Any European nation would eagerly grasp at such advantages of favor to establish commercial ties. But while our trade in the Near East may be said to have the possibility of foundation upon a broad basis of philanthropy and confidence, we have thus far almost neglected this commereial open door. It is high time that we consider the Near East as a trading center of vast importance lying along one of the greatest and oldest commercial trade routes of the world.

It is largely because of such interest as the United States has shown in the Levant that the populations there, especially the Turkish section, subsequent to the war, hailed with eagerness the idea of a mandate making possible American supervision. While this matter is one of doubtful policy in the minds of many Americans, it has given ample reason for belief in the moral and political favor with which the Near East looks upon the United States. This is a factor not to be overlooked as an element of great value in any move we may make in the near future toward trade and shipping relationships.

While we have with justice given our attention and trade to Latin Ameriea, since these populations are near and belong to our own liemisphere, to China and the Far East where our Philippine interests have lured our commerce, it must be kept in mind that there exists no portion of the earth of equal extent to which American cxporters thus far have given so slight attention as to the Levant. 
That there is ample reason lying in the rich, almost untouehed resources of this section for our trade interest, can be easily demonstrated. For proof of this, referenee may be made simply to the coal fields along the Blaek Sea; the oil fields of the Persian Gulf; the extensive grain fields, where the yield as it is conservatively estimated could be raised in a decade to $200,000,000$ bushels; the great copper areas upon which France is centering her attention; the cotton possibilities in Mesopotamia ; the wool of Asia Minor; the natural silk areas; and the region furnishing the world's supily of opium, licorice and the fine tobaceos.

To quate from a report by Lewis Heek, of the Ameriean consular service, regarding our import and export trade with the Near East:

Before the war the United States bought from the Near East some fifty million dollars' worth of goods, principally raw materials such as cotton from Egypt; tobacco, wool, mohair, skins, opium, rose oil, licorice root, dried fruits and nuts, etc. from Turkey; skins and eoffee from Aden; dried fruits, eheese, olive oil and tobaceo from Greece; copper and plum jam from Serbia; rose oil and tobaceo from Bulgaria; reclaimed rubber and wool from Odessa; lieorice root, wool, manganese and hardwoods from Batoum. The manufactured goods consisted of carpets and rugs, laces, and eurios, etc., and represented only a small proportion of the total. In general, the region is agricultural and pastoral rather than industrial, and there is but relatively slight industrial derelopment in any of these countries, so that for many years to come they will have to import manufactured and finished merchandise and will not have much in these lines to offer for sale in other countries. Their elimates and soils enable them to produce better than elsewhere certain staple articles for which there will always be a demand in western Europe and the Lnited States, and they will have their natural products to offer in exchange for their importations of finished commodities, until such future time as their own domestic industries shall come to a greater degree of production and variety.

For this reason the countries of the Near East offer a permanent field for the sale of the products of industry and manufacture, the value of which has always been fully recognized by our main 
competitors in Europe, although we have often overlooked it because of its distance and of relatively larger markets elsewhere. Nevertheless, a portion of the world which annually imported some $\$ 550,000,000$ worth of foreign goods before the war is worthy of closer study now that our exporters have waked up and are both ready and eager to really go after a fair share of this trade, instead of waiting till some small share of it comes to them of its own accord.

On the export side, we sold to all the Near East, including Southern Russia, goods to a value of between ten and twelve million dollars per annum before the war. A large proportion of this total consisted of mineral, animal and vegetable oils; textiles played a smaller and decreasing part, as we had to givo way to more active British and Italian competitors. We had some small business in leather and hides, shoes, rubber overshoes, typewriters and supplies, agricultural machinery, the better grades of tools and certain American specialties, but in the principal staples which form the bulk of any real volume of trade we had almost no share, in spite of the fact that for the exports of Turkey we were the second best customer, next after Great Britain, and also bought the second largest share of Egypt's principal crop. The heavy trade balance against us was paid for by remittances from immigrants to their home folks̀; by sums expended for American schools, missions, and colleges, etc.; by tourists' expenditures, for many thousands of them annually visited Egypt, Palestine and Constantinople; and by financial adjustments through European countries. These remittances and expenses, of course, increased our debt to the Near East, but hereafter we should be able to exchange an increasingly larger volume of our own products for the goods we buy.

It must be remembered that whatever trade we have had with this section has been done practically with little or no American shipping to this region, depending upon foreign nations not only for ships but banks and other facilities. It was the writer's privilege to pass through the Suez Canal at the time that our American fleet in its voyage around the world was returning and lay in the Suez Canal. An Egyptian business man said then that the people of the present generation in the Near East had never 
seen before the American flag floating from any vessel save possibly from an occasional American pleasure yacht or from a small tramp steamer too insignificant to make any particular impression upon any one. In fact, outside our diplomatic and consular service, there was no organization for trade in this section until in 1911 the American Chamber of Commeree for the Levant was formed. This body now has a membership of 600 firms and individuals located for the most part in the commercial centers of the Levant.

While trade relations of the United States with Turkey and considerable of the Balkan peninsula during the period of the war were of small importanee, there was quite a large volume of dollar exchange carried on which helped to accustom local merchants and local bankers in the Near East to the habit of dealing with the United States, also to establish eredits in this country which have been used to purchase American goods.

The American Embassy at Constantinople was connected with a sale of dollar exchange to the amount of more than $\$ 10,000,000$ to provide funds for relief in charitable payments of various sorts. The Entente Governments furnished several million dollars of this fund since the American diplomatic and consular representatives looked after the interests of these Governments during the fighting period. There were several million dollars deposited with the State Department to individual beneficiaries and treasuries and a considerable amount was left in funds in relief organizations, such as the Armenian and Syrian Relief Committee, and the Joint Distribution Committee of the Jewish Charitable organizations.

Trade relations with the United States were kept up by Egypt and Greece during the war and both of these countries have prospered along different lines since 1914, so much so that Greek currency has been kept almost at par. The Egyptian situation although affected somewhat by political agitations and labor troubles, is on the whole promising.

The following table gives a general idea of Egyptian 
trade, together with imports from and exports to the United States :

\begin{tabular}{c|c|c}
\hline & Total Exports & Total Imports \\
\hline 1914 & $\$ 120,218,062$ & $\$ 108,405,784$ \\
1915 & $134,963,892$ & $94,451,676$ \\
1917 & $204, \$ 92,454$ & $\mathbf{1 5 8 , 8 7 6 , 6 0 8}$ \\
1918 & $226,396,400$ & $255,264,976$ \\
\hline
\end{tabular}

\begin{tabular}{c|c|c}
\hline $\begin{array}{c}\text { Year ending } \\
\text { June }\end{array}$ & Imports from U. S. & Exports to U. S. \\
\hline 1919 & $\$ 10,293,189$ & $\$ 23,934,571$ \\
1920 & $27,129,609$ & $105,872,508$ \\
1921 & $29,118,357$ & $26,437,350$ \\
\hline
\end{tabular}

According to consular reports, exports from the United States to Greece increased from $\$ 1,123,511$ in $1913-14$ to $\$ 48,672,778$ in $1919-20$, and to slightly over $\$ 37,800,000$ in 1920-21. There are few countries which show a like increase during the war. In the fiscal year ending June 30 , 1914, we shipped to Egypt goods to an amount of $\$ 1,930$,108. In 1920-21 our total exports to Egypt were $\$ 29$,118,357. These two countries bought from us in 1916-17 more than three times as much as the entire Near Eastern field in 1913-14.

It may be pointed out that we have special ties with Greece since there are more Greeks in the United States than in any country in the world, excepting Greece. Americans are also popular in Egypt and are large purchasers of Egyptian cotton, the most important product of that country. It must be remembered, however, that Egypt has long been a British dependency and notwithstanding the new degree of independence gained by Egypt, British trade here will be naturally considerable.

Turkey furnishes interesting possibilities for trade with 
the United States sinee many of the old commercial ties with Europe have been broken and because of the need of utilizing the great potential wealth and resourees of this eountry.

According to a report of Louis Heck of the American Consular Serviee, in the few years before the war we bought from Turkey about $\$ 22,000,000$ worth of goods each year, of which tobaceo represented about half of the total. We sold to Turkey, on the other hand, not more than an average of $\$ 3,500,000$ per annum. The prineipal American establishments in Turkey were edueational and missionary. Next to the French, whose religious orders have been engaged in missionary, and educational aetivities in Turkey sinee the days of Louis XIV and longer, there were more American schools, missions and colleges than those of any other nationality, ours outnumbering all the others put together exeept the Frenel.

We also have the most prominent and conspieuous colleges, such as the University at Beirut, Robert College and the Girls' College at Constantinople, the International College at Smyrna, and several large and admirably conducted institutions in Egypt. In almost every eity of importanee in Asia Minor and Syria the traveler is likely to see a large and well constructed group of buildings, standing out notably among the other structures of the city, and upon inquiry he will be told that these buildings belong to the Americans.

Hospital and medieal aetivities were among the main features of missionary work and were badly needed in a country where extreme ignoranee prevailed and doctors were few and unskilled. In more recent years other practical lines have been taken up, so that to-day Robert College has the first real sehool of engineering in 'Turkey, and plans are ready for agrieultural courses for both Robert College and the University at Beirut as soon as conditions permit their execution.

Besides the schools and eolleges, we had the buying agencies of the various American tobacco companies and the 
MacAndrews \& Forbes Company; the selling and production agencies of the Standard Oil Company of New York, the Vacuum Oil Company, a branch of the Guaranty Trust Co. in Constantinople; American Express Co. in Constantinople, Cairo and Athens; and the ommipresent and widely extended organization of the Singer Sewing Machine Company. Beyond these principal concerns there were very few that were distinctly American in character. Thero would be occasional visits from American business men who happened to go to Turkey; or, on one special oceasion in recent years, there was the attempt to obtain a concession for a 1200-mile railway known as the Chester project, which was designed to open up valuable mineral regions, and for which a total investment of $\$ 100,000,000$ was planned. This scheme was defeated in 1911 after a hard fight, principally by German opposition, but the need for such a road still exists, and had it been constructed before the war, the strategic position of Turkey against the Russian armies in the Caucasus would have been vastly stionger.

The handicap which the United States suffered in furnishing large food supplies, especially flour, for Turkey subsequent to the signing of the Armistice, was found in not having an American bank through which to work. It was necessary to use a British firm and a British bank in supplying American food products to render this assistance to a hungry and nearly war starved city.

The arrival of 350 workers belonging to the American Committee for relief in the Near East, together with an international mandate commission headed by Charles $R$. Crane and Dr. Henry King of Oberlin College inereased in Turkey the high opinion of America's desire to play fair and to assist in the settlement of Near Eastern problems.

Trade with this section has been greatly helped of late by new lines of regular and direct American steamers such as we have never had in the past to the Near East. In recent shipping lists there will be found three or four vessels leaving each month from American ports for Constantinople and other points in the Levant. 
A large number of Amcriean firms have been sending their own representatives to the Levant, but in this we havo been outstripped by the British, French, Italian and Japanese, who have followed the policy of sending largo delegations to promote trade with their various eountries. At Constantinople there was, not very long ago, a Japanese delegation of 30 members and soon afterwards there was a large importation of Japanese eotton goods. Our eompetitors in this section are capable and formidable. Such corporations and its subsidiaries as the Levant Co. Limited, which has acquired a controlling interest in the largest British trading house in Turkey, in the only British Bank, and is eloscly affiliated with the largest and leading firms, is one of Great Britain's plans for the resurrection of trade on a large scale.

The British control of the oil fields of Mesopotamia as well as those of Arabia and Persia which are among the richest in the world, has brought under Great Britain's eontrol a field of production of almost inestimable value.

The French, moreover, have not only had long established conneetions and considerable investments in Turkey, but they have been giving attention since the war to the extension of their trade in the Turkish Empire. A large French Commission, whiel included the head of one of the National Export Associations of Franee, has visited the important trade centers of the Near East. The French have a eertain advantage in the ready currency with which the Freneh language is utilized throughout the Levant as a commercial medium of expression. There are certain other advantages held in this seetion by the Italians because of their close proximity and by reason of the fact that they have fallen heir to many of the Austrian comnections with the Levant, particularly in matters of banking and shipping. The Austrian Lloyd Steamship Company, which was the largest and most important fleet of vessels in Near Eastern waters, now flies the Italian flag and the ships are reported to be rumning on approximately their old schedules.

The activities of the Greeks in this section have been 
confined largely to trading and dealing in goods imported from other countries since there are few industrial products in Greece to export.

An American banking house in this section is greatly needed, not only for commercial transactions, but to provide a basis for investigation, investment and the development of resources in the Near East, as there are rich mines in Asia Minor of copper, coal, iron, silver, lead, zinc, etc., which are only waiting to be scientifically explored and developed.

In this agricultural and pastoral section where irrigation and farming projects on a large scale are certain to come, all kinds of agricultural machinery, tractors and motors will be required previous to the building of more railways. There is a great need of hydroelectric development. It is said that at present not more than twenty per cent of Turkish agricultural products are touched by any but the most primitive tools and with methods such as are native to the country. The American opportunity for the development of public works and transportation generally is patent.

Turkey, with a popnlation of 20,000,000 in the year 1914 and an area of 695,000 square miles (more than 15 times the arca of Pennsylvania), had less than 5000 miles of railway and only three cities had electric light plants or electric street railways. It seems strange to realize that Constantinople itself did not possess telephones, electric street cars or lights until the year 1913.

The Amcrican automobile market which has already been opened in so many foreign lands finds in this region almost virgin soil. In 1914 it is stated that there was less than one automobile to each 200,000 inhabitants in Turkey.

In spite of the politieal vicissitudes of Turkey and her debt of $\$ 2,000,000,000$, Turkish money has been worth more in exchange than any other paper currency of the former Central Powers and is slightly better than that of such countries as Poland, Czecho-Slovakia, Jugoslavia and Roumania.

As to Bulgaria, Serbia, Roumania and Trans-Caucasus 
there will be found opportunities for American trade as soon as our manufacturers and traders are ready to seriously enter these fields.

The large number of Bulgarian students at Robert College, the cousiderable immigration from Bulgaria to the United States numbering upwards of 75,000, and the highly agricultural and pastoral nature of the country requiring imported manufactured goods, all offer inducements to American commerce.

Serbia, or the Kingdom of the Serbs, Croats and Slovenes, otherwise known as Jugoslavia, is in need of manufactured and finished articles, while the population is sympathetic with the United States because of our aid in the war. There is an estimated surplus of cereal production in Jugoslavia for the past year which should provide upward of $1,000,000$ tons of grain for export. There will be need of the extension of credit in order to do business at present in this country and probably longer credits, in most of the other Near Eastern countries, than we have been accustomed to give.

Roumania with her agricultural prosperity and oil fields, having about the same arca as Italy and a population of $15,000,000$, also large areas of coal, iron and copper resources, is the one country in this section to which the United States sold more than it bought previous to the war, the balance in our favor being about 4 to 1 .

While Southern Russia presents a complex and uncertain condition for trade, Trans-Caucasus with the three small republies of Georgia, Armenia and Azerbaidjan, has also great natural resources, especially minerals. In 1913 the Caucasus produced over 1,000,000 tons of manganese of which 121,887 tons were sent to the United States. Other mineral products include copper, cement, salt, coal and carbonate of potash. Tobacco and licorice root and hard woods such as Circassian walnut have also been coming to the United States from this region. Trade has been resumed to a certain extent with the Caucasus and there has been 
talk of an Anglo-Armenian bank and a British project in this region to develop hydroelectric plants.

As to our trade with Persia in the past it has been hardly worth mentioning, amounting to only a few thousand dollars a year. There have been some indications in late years of closer relations and the Shah of Persia purchased several hundred thousand dollars' worth of Liberty Bonds. Previous to the war the total import trade of Persia amounted to about $\$ 40,000,000$.

Although certain sections of this Near Eastern field are at present more or less demoralized because of the results of the war, European traders are sparing no nieans to establish firmly their positions there. It will take effort for American traders to secure firm and abiding markets, but that this great section of the earth should not be neglected by us goes without saying.

There are signs of progress in the recent establishment of American Chambers of Commerce in Egypt with headquarters at Alexandria, and the American Chamber of Commerce in Greece with an office and secretary at Athens. American automobile business has also gained headway recently in the Levant.

It has been truly stated that the discovery of the American continent formed one of the chief causes contributing to the decline of the trade routes from Europe to the East by way of Turkey as well as to the eclipse of Constantinople, of the Italian maritime republics, and the trade of the eastcrn Mediterranean.

It would seem appropriate that America and its American commercial leaders with American capital, brains and stable business methods, should take their part in rebuilding the economic structure of this historic region, thereby utilizing particularly our American manufactures and machinery in a territory where perhaps they are more needed at present than in any other section of the earth. 


\section{CHAPTER XXII}

\section{AMERICAN OVERSEAS TRADE WITH AFRICA}

To the last, to the largest empire,

To the map that is half unrolled!-Kipling.

It is many years ago now since Livingston sent back word from darkest Africa to his English constituency, saying, "The end of the exploration is the beginning of the enterprise."

For a considerable period of years Africa has been in the commercial eye of various nations. Great Britain with her protectorate over Egypt in the Valley of the Nile replaced former French influence in that section and although the inhabitants of this most ancient country have been given recently a larger share of national control, there is no doubt that British influence and British trade will dominate in the ancient land of the Pharaohs for many years to come.

When one considers what the English have done through the foundation of government schools in Egypt, in the reclaiming of vast tracts of Egyptian land for agriculture, in large engineering and railroad enterprises along the Nile, as well as in their contribution to the stabilizing of business and government through the work of such men as Cromer and Kitchener, much eredit must be given to the colonial Britisher.

Egypt is located strategieally at the gateway betwcen the great trade routes of the East and West. Herodotus, more than a thousand years ago, said: "I speak at length about Egypt, because it contains more marvelous things than any other country, things too strange for words." The 
Greek historian goes on to point out in detail some of the oddities, and to the Westerner the abnormalities of this Oriental land:

Other nations in weaving throw the woof up the warp, but the Egyptian throws it down; in other countries the Priests of the Gods wear hair, in Egypt they are shaved; in other countries the dwellings of men are separated from those of beasts, in Egypt men and beasts live together. Other nations fasten their ropes and hooks to the outside of their sails, but the Egyptians to the inside. The Greeks write and read from left to right, but the Egyptians from right to left.

And these peeuliarities of the Egyptians may be traced virtually to every phase of this people's life. It is ancient as it is strange; more than medieval, this Egypt, unchangeably and inexplicably ancient, a part of the slow moving east, the land of timelessness; as the Khedive Ismail once said, "To-day is here the same as yesterday, and tomorrow will be the same as to-day; and so it has been, and so it will be, for thousands of years."

It is like a page from the old pictorial family Bible out of which we spelled the letters at our mother's knee.

In sailing down the Nile you see the Egyptian peasant using the same hand propelled shadoof that his fathers used in the time of the Pharaohs, while grave fellaheen ride solemnly along the paths upon donkeys that might have been the direct descendants of those that bore father Abraham when he went out to a land that he knew not of. In the village "kuttabs" (small Moslem schools) I found the ancient looking Sheikh in turban and flowing robes, exactly as he might have looked ten centuries ago, with his band of half-elad boys about him, repeating in a sing song refrain the long unintelligible words of the Koran, keeping time with their swaying bodies, while the school-master accents their recital by expressive grunts and flourishes of his pedagogical cane. In short, if you have known Egypt once, you have known it for all time. In the words of Miss Amelia B. Edwards : 
The physique and life of the modern fellah is almost identical with the plyysique and life of that ancient Egyptian laborer whom we know so well in the wall paintings of the tombs. Square in the shoulders, slight but strong in the limbs, full lipped, brown skinned, we see him wearing the same loin cloth, plying the same shadoof, ploughing with the same plongh, preparing the same food in the same way, and eating it with his fingers from the same bowl as did his forefathers of six thousand years agowater is bronght to table in the same jars manufactured at the same town as in the days of Cheops and Cephron; and the mouths of the bottles are filled in precisely the same way with fresh leaves and flowers. A Sheikh still walks with a long staff; and the pleasure boat of the modern Governor or MIndir, as well as the dahabeeyah hired by the European traveler, reproduces in all essential features the painted galley represented in the tombs of the Kings.

A New Industrial Order.-The first question in this country is an agricultural or industrial one, as it should be, for the suecess of Egypt like that of any other nation is based first upon the land, and the country that has not fostered a steady and ever expanding material development will vainly strive to make up for this deficieney in any superstructure, however perfect. This industrial or utilitarian awakening has been so rapid and so decided that the Egyptian has hardly recovered himself suffieiently to realize what it is all about.

Seventy years ago the Indian mail was transported in a box which was loeked by the Consul in Alexandria and went to Suez on a camel. The first railway of Egypt from Alexandria to Cairo in 1855 was the promise of a railway system which now conveys the traveler with every modern convenience from Alexandria to Khartoum. It seems well nigh incredible to think that only a half century ago in this eountry the coal and merchandise for the mail steamers were eonveyed by caravans aeross country, these caravans frequently consisting of three thousand eamels; or that during the same period the opening of the Suez Canal and the country wide plans for irrigation and national and 
international eommunication have united Egypt with the world's federation of modern business. The commerce from all the seas of the world is beginning to flow into Egypt. She is leaping into the light of a new day. Her cotton, her credit, her farming, and her institutions are all comparatively new and strange in their modern dress.

To the people at home, as well as to the nations abroad, this industrial renaissance is absorbingly interesting. "To watch the immemorial culture of the East," writes Kenneth J. Freeman, "slow moving with the weight of years, dreamy with centuries of deep meditation, accept and assimilate as in a moment of time the science, the machinery, the restless energy and practical aetivity of the West, is a fascinating employment."

The Egyptian farmer is quite another factor in Egypt's life than he was when the British found him on their occupation thirty years ago. Egypt has to-day one million two hundred thousand yeomen, each owning upwards of fifty acres of land apiece, and showing signs of becoming no longer "voiceless masses," but citizens with wealth, vested rights and intelligent claims. These fellaheen are primarily responsible for the fact that in 1910 the cotton exports from Egypt amounted in value to 24,242,000 Egyptian pounds, that sugar was exported to the amount of 515,000 tons, and that 288,000 Egyptian pounds were realized from the export of rice, while practically a new day of industry has been made to dawn, by these sturdy fellaheen, in the cultivation and harvest of garden produce. The majority of these agriculturists have received water for their land from the hands of the English engineer; they are no longer bullied and frightened from their rights by over-bearing village Sheikhs, or deprived of their lands by arbitrary edicts of a foreign Pasha. The man of Egypt no longer puts out an eye to evade military service as he did in the old days of oppression, neither is it his chief aim in life to evade the extortions of the tax gatherer.

In the next generation these blue skirted peasants, whom the Nile tourist, floating down the river in the lusury of his 
dahabeeyah, photographs at his eircling sakich, or stooping and straining at the shadoof, will be men to whom the very mention of such atrocities will seem unbelicvable. They will be men of rich properties and growing minds, separating themselves more and more from that herd instinct which is the bane of belated races. It is, indeed, donbtful whether history reeords another instance of so sudden a leap from abject misery and slavish poverty into the beginning of affuence and material prosperity as are now in evidence in agricultural Egypt.

In spite of this general apathy among the masses of Egyptians, whose only idea of the modern Egyptian awakening is that which comes to their material appreciation, one finds in the large eities a new sense of representative responsibility. Witness the new schools for law, which are turning out each year hundreds of Egyptian students educated in modern judicial procedure; in short, the cynosure of the voeational hopes of Egyptian students have been for the past decade riveted upon the profession of lawyer or judge. Seores of new schools have been established of late by the Moslems and the Copts, having direetly in view the making of citizenship through the avenues of: practical, commereial and legal education. These institutions, together with those in charge of the foreign missionaries, whose edueational ideals are inereasingly progressive and utilitarian, are erowded to overflowing with Egyptian young men determined that the foreign Syrian or Greek or European will not fileh from them much longer the prizes of commercial and national eitizenship. There is hardly a vocation with which we are familiar in the West which is not to-day beginning to receive attention by these coming citizens.

Alexandria, the eity which was famous in other centuries for its trade as well as for its learning, now holds the possibility of again becoming a great world and maritime port.

Among the growing industries of this old eountry are 
those involving Egyptian cotton and other textiles, cereals, tobacco, skins and leather goods, as well as many other commodities like drugs, metals and chemicals which figure among Egypt's modern exports.

Algeria.-As Great Britain has laid the basis of world trade in Egypt and the Sudan, so France has brought to Algeria, Moroceo and the fruitful shores of the Southern Mediterranean, the development of native resources, the construction of military roads, the cultivation of huge vineyards, and through her colonists by actual example engaging in agricultural pursuits.

The author was amazed a few years ago in taking a somewhat extended journey through Algeria to see the manner in which French civilization had stamped itself upon the ancient and somewhat backward civilization composed of Kabyles, Arabs and a mixture of old European races. In this historic section where Romans, Africans and Byzantines met and fought for supremacy in other centuries, modern industries and opportunities are coming into being.

Imports into Algeria during the period January to March, 1920 , amounted to $\$ 56,204,109$ and exports to $\$ 97,283,773$, making a total trade of $\$ 153,487,882$, which was an increase of $\$ 42,954,466$ over 1919.

In the Central Coastal Region and in South Africa particularly modern foreign trade has made enormous strides forward. The loss to Germany of provinees through the exigencies of the war have given Great Britain a firm hold upon the trade of Central Africa. That this trade is increasing and that great possibilities exist for advance is shown by the fact that the Accra district, for example, in British West Africa leads all other sections in the world to-day in cacao production, sending to the United States alone more than 100,000 tons yearly.

South Africa.-In order to understand the resources and economic conditions of South Africa it is necessary to know something of the physical structure of the country. The land south of the Zambesi river may be divided into 


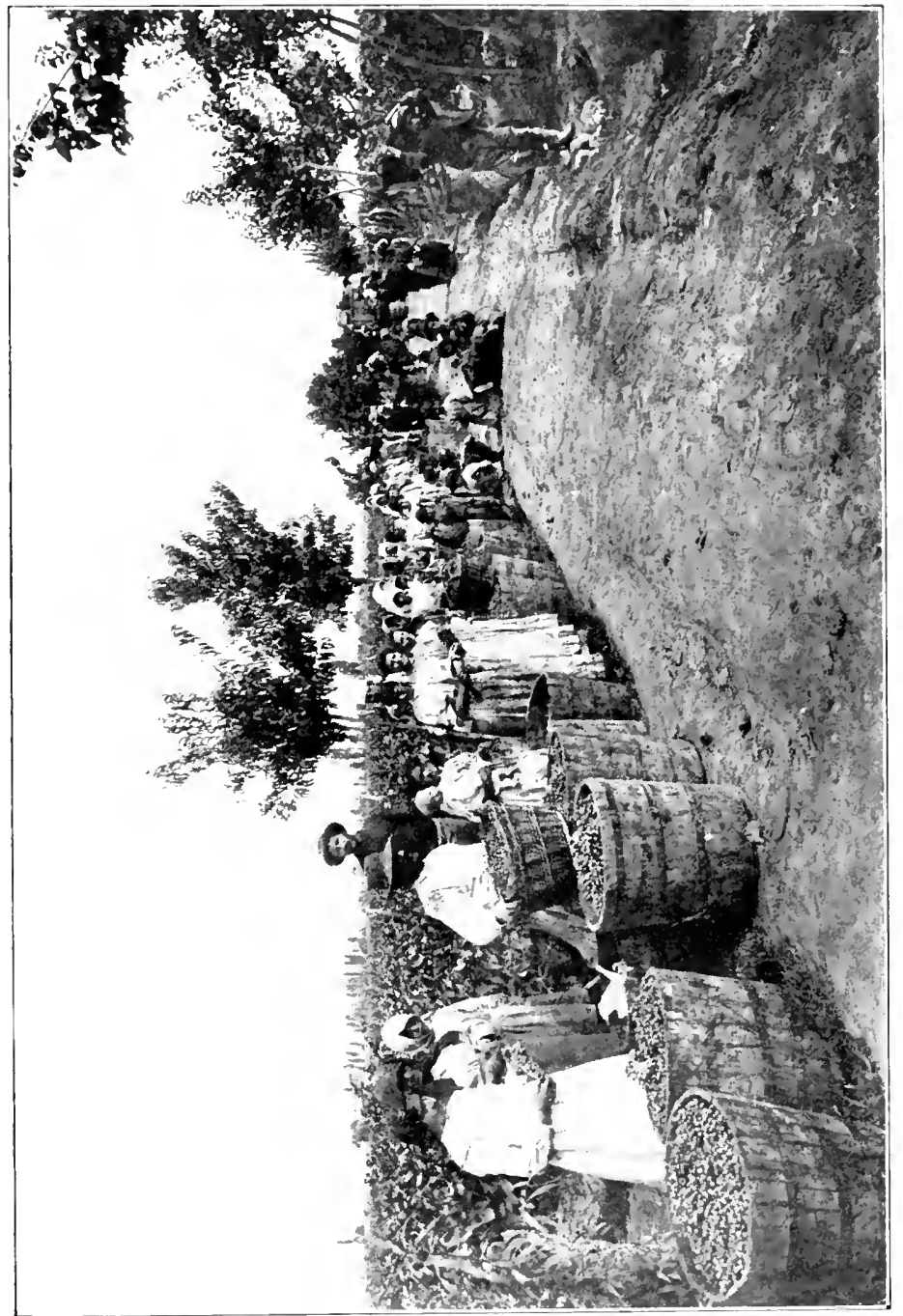

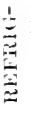

$=$

党

$=$

$\equiv \bar{x}$

$\underline{\underline{5}}$

$\underbrace{2}$

$=2$

:

난

당

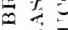

的

西

开宁

ต

$\simeq$

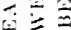

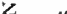

管

ㄴ.

$\div=$

面

$\gamma \equiv$

5

군

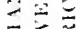

$\Xi \pm$

㞣

두

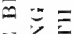

制

西

픈

7.

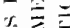

군

要

$5 \%$

$\cong$

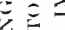

正

空

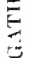




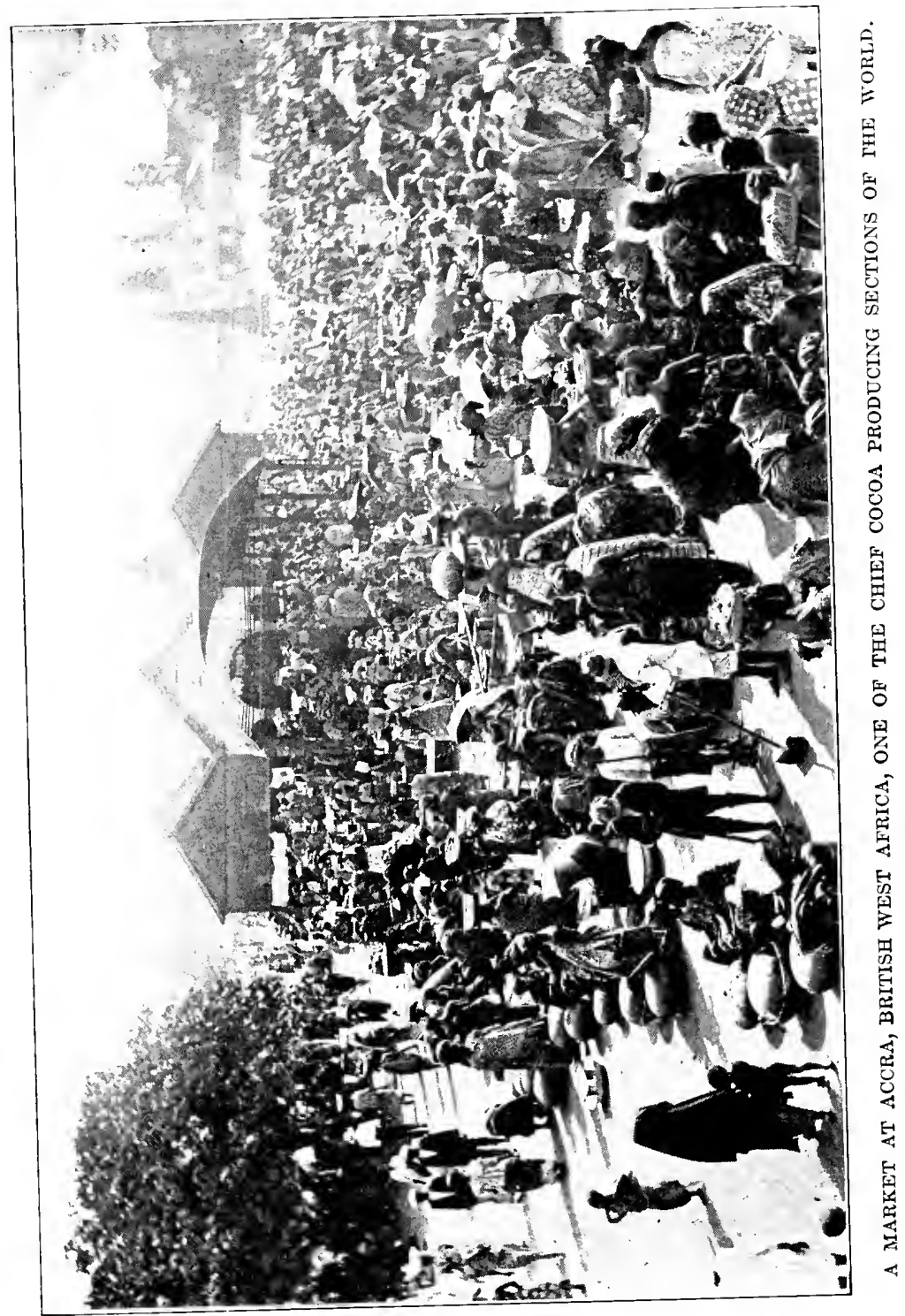


three regions. There is a low strip of land bordering on the Indian Ocean which extends from Cape Town past Durban, Delagoa Bay and Beira to the south of the Zambesi. Behind this low coast belt lies rough, hilly country which gradually rises as one goes inland to an altitude ranging from 3000 to 7000 feet and in some places reaehing an altitude of 11,000 feet. A vast high tableland fills in the interior behind this Quathlamba Range. Thus the main features consist of this considerable mountain chain with rocky, hilly country between it and the low lying coast plain, and the vast tableland stretching behind it into the interior.

The elimate is extremely dry, the air being clear and stimulating. The heat is intense, but generally cooler than that found at a similar latitude in northern hemispleres. Although the sum is very hot, sunstroke is unusual and the natives do not have to be on constant guard against the sun as in India and other countries. Most of South Afriea is high and dry, but all of it is hot. The freshness and purity of the air tend to produce a vigorous raee whieh ean resist the heat. The high and dry parts are naturally the most healthful. In the low belt, where it is wet and swampy, malaria prevails and is the scourge of the east and west coast.

The eoast has extremely few harbors and unfortunately the country itself has few rivers and such as there are practically unserviceable for navigation three-fourths of the year. This is one reason why the continent remained unexplored for such a long time. Unlike North and South America, where explorers penetrated the eountry by following its waterways, in South Africa they were obliged to use ox-wagons and make frequent stops to feed the animals.

The chief sourees of the country's wealth are its agricultural land, its pasture land and its minerals. Agrieulture is the least important of these. The ehief agricultural products are wheat, oats, maize, eorn, fruit and sugar. In the past more attention has been given to pastural pursuits than to the cultivation of crops. In this way the 
great agrieultural resourees of the country have scarcely been touched. The future of the country will depend to a great extent on the development of these resources and the government is giving serious attention to such development. The interior land which is too dry for suceessful agriculture furnishes excellent grazing country. The raising of eattle, sheep and goats has been for years a well developed industry. The mineral souree, the last to become known, opened a new period for South Afriea. It brought erowds of immigrants and helped to develop trade. This mineral region is one of the world's best. The gold mines of the Transvaal are the richest in the world and the diamond mines of Kimberley supply 98 per cent of all the diamonds used. The working of these mines is the greatest industry of the country. Just what will happen when these mines are exhausted is hard to prediet. There will be no reason then for the mine workers to stay and population may decline or the people may turn to other activities.

South Africa, like many other countries, experienced difficulty in the latter part of the war period in obtaining urgently needed supplies from foreign countries and like other countries, she too began to develop more extensively her own resourees. This resulted in a widespread development along industrial lines. These industries continued to be aetive in 1919. Many of them enlargea their plans and inereased their output, while new ones were begun. In the Union of South Africa since 1915 no less than 2000 new factories have been established and the output per annum of these factories is approximately $£ 61,000,000$ ( $\$ 297,000,000)$. The industrial production has inereased 50 per cent in the past four years and the country is rapidly advancing in the direction of becoming self-supporting in all the necessaries of life. The year 1919 was a most prosperous one for South Afriea. The universal demand for raw material stimulated produetion and the country benefited by the prevailing high prices. Further proof of the increased activity in business conditions was to be seen in the large deposits accumulated in the banks. 
The total foreign trade of the Union of South Africa, which is about one-sixth the size of the United States and is composed of four provinces, Cape of Good Ilope, Natal, Transvaal, Orange Free State, was the largest since the formation of the Union in 1910. This trade in 1919 was valued at $\$ 672,942,343$ as compared with $\$ 575,198,034$ for the year 1918 and $\$ 532,671,000$ for the pre-war year of 1913. In 1919 the exports including raw gold were valued at $\$ 425,766,974$ and the imports $\$ 247,175,399$. The excess of exports over imports amounted to $\$ 178,591,575$. This showed a decided inerease orer that of 1918. In 1913 54.4 per cent of the total imports into South Africa eame from the United Kingdom and only 9.5 per cent from the United States. In 1919 the percentage from the United Kingdom was 45.4 per cent, while that of the United States had risen to 24.1 per cent.

Considerable apprehension was felt in South Africa concerning the general slump in trading and the marked decline in all prices in 1920 . The total value of the declared exports of Cape Town to the United States for the six months ended June 30, 1920, amounted to $\$ 2,912,163$, as against $\$ 3,164,756$ in January-June, 1919, being a decrease of $\$ 252,593$. The recent deeline in prices in South African markets of wool, skins, hides, feathers and diamonds, as well as the action of banks in refusing to handle foreign exchange is largely responsible for the decline. This general fall in prices has reacted unfavorably on the commodities produced for export in the Union of South Africa.

According to a report by Consul Fred D. Fisher, July 31st, 1920, a Chamber of Commerce of the United States of America was formed in South Africa at a meeting held in the American consulate in Johannesburg on July 30th.

In organizing this chamber the constitution of the American Chamber of Commerce in Argentina has been followed, with such alterations and additions as local conditions necessitate. In order to give it a legal status and to limit the liability of its members, the chamber is duly registered in the Transvaal Province. 
The following table gives some idea of the trade development in the Union of South Africa:

\begin{tabular}{|c|c|c|}
\hline Principal Exports & 1912 & 1918 \\
\hline 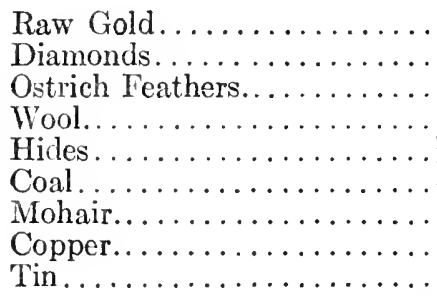 & $\begin{array}{r}\$ 186,600,000 \\
44,500,000 \\
12,700,000 \\
23,280,000 \\
8,210,000 \\
5,850,000 \\
4,720,000 \\
2,100,000 \\
1,192,000\end{array}$ & $\begin{array}{r}\$ 34,200,000 \\
431,000 \\
47,200,000 \\
11,180,000 \\
4,870,000\end{array}$ \\
\hline $\begin{array}{l}\text { Total Imports (\$U. S.) . . } \\
\text { Total Exports (\$U.S.) . . }\end{array}$ & $\begin{array}{l}203,300,000 \\
324,100,000\end{array}$ & $\begin{array}{l}240,800,000 \\
160,700,000\end{array}$ \\
\hline
\end{tabular}

Nembership in the chamber is open to American firms and individuals resident in any part of the Union of South Africa, Portuguese East Africa, Belgian Congo, South West Africa and other protectorates. The officers elected for the remainder of the year 1920, were: President, C. D. Healy, manager of the Standard Oil Company; vice president, Frederick V. Green, South African representative of the Baldwin Locomotive Works; secretary, E. W. Harris, joint manager of the Denver Rock Drill \& Machinery Company; treasurer, W. Otis Bullock, managing director of the Colonial Banking \& Trust Company.

It is the desire of the chamber to maintain cordial coöperation with the United States Chamber of Commerce at Washington and with other chambers in the United States intercsted in the extension of American trade and enterprise in South Africa.

Industrial Development in South Africa.-That there is far-reaching reason for such a Chamber of Commerce is revealed by examining the official trade returns for the Union of South Africa for the third quarter of 1920. These 
returns show an enormous increase over the foreign trade of the corresponding quarter of 1919 , according to report made not long ago by the Foreign Trade Bureau of the Guaranty Trust Company. Imports increased by well over $\$ 16,000,000$ and exports by nearly $\$ 36,000,000$, exclusive of raw gold. The total value of imports was about $\$ 80,000,600$ and that of exports by close to $\$ 116,000,000$, including raw gold, which amounted to a little over $\$ 32,000,000$. Exports of wool were in the neighborhood of $\$ 43,000,000$.

A considerable expansion is expected to take place in the production of fertilizers, where much raw material, such as offal from abattoirs and crayfish canneries, which might be converted into fertilizers, is allowed to go to waste.

A growing demand for railway truckage is reported from every part of the Union. The railway finds this demand difficult to meet, although new freight cars are constantly being placed in service.

During the month of May, the Johannesburg municipality approved plans for new buildings, including additions and alterations to the value of $\$ 800,000$. Building materials are very scarce and prices are increasing, particularly on lumber, but nothing seems to check the building progress.

In an annual report of the Department of Mines and Industries, an extract which appears in the Chamber of Commerce Journal of London, shows a promising industrial situation in the Union of South Africa. The following notes regarding industries in that section reveal the present and future possibilities:

Cotton and Fiber: Much more interest is now being shown in the cultivation of cotton. Even sugar planters are going in for its cultivation to some extent. With a greater area nnder cotton there will be larger supplies of cotton seed available for oil extraction, and undoubtedly these supplies of cotton seed will be treated within the Union. Anotler oil-seed bearing crop is flax, about which and the linseed obtained therefrom numerons inquiries have been received. Mention should also be made of sisal, the eultivation of which has greatly increased, and at no far distant date the Union should be supplying its own require- 
ments of sisal hemp for the manufacture of rope, twine, sacking, etc., an industry which has made great progress during 1918.

Foodstuffs: Additional cold storage works and depots were ereeted during 1918, while the production of cheese, bacon, butter, condensed milk, foodstuffs from cereals and cereal by-products, such as stareh, glucose, dextrine, malt and malt extracts show highly satisfactory inereases.

General Industries: Very gratifying progress has been made in the produetion of drugs and chemicals, paints, soaps and eandles, sugar by-products, cement and cement manufacture, furniture, glassmaling; boots and shoes, pickles and condiments, glue, fertilizers, basketware, rubber goods, sheep and cattle dips, and ironsmelting. A tin-smelting works has been started, while in the production of coke a commencement has bcen made with byproduct plants.

Future Possibilities: In regard to future possibilities the Report points out that the present is undoubtedly a favorable opportunity for the investor to put capital into the development of the Union resourees. Great possibilities lie in the direction of steel production, of coal by-product and maize by-product industries, of woolen manufacture, fiber and cotton production, shipbuilding and repairing, and the development of the deep sea fisheries. In that section of the Report dealing with the production of base metals and minerals, it is noted that the Union is to-day the world's leader not only in the production of gold and diamonds, but also of corundum, and that it possesses the largest known reserves of these minerals. In the production of asbestos the Union comes fourth, and in coal it is the eleventh largest produeer. Comparing the year 1918 with 1913, there has been an increase in the production of salt, lime, corundum, asbestos, gypsum, soda, magnesite and graphite. Copper, tin and lead show an appreciable deerease in output, but on the other hand, many other base metals and minerals have been produced in inereasing quantities, which do not figure in the pre-war tables, among them being iron ore, iron pyrite, iron oxide, manganese, tungsten and miea. The Union is also supplying the whole of the local demand for talc and tale produets. The greatest progress has been made in the production of asbestos and corundum, and it is promising to note that both of these industries are eapable of very great expansion. No other country in the world can compete with the Union as regards varieties and fibres of asbestos. Another good sign in this connection also is the announcement in 
the Report that a beginning has been made in the manufacture of asbestos goods of excellent quality, there being made locally roofing, slates and tiles, boiler lagging, stove bricks, jointing, packing, etc.

Already American engineers and American business men have had a part in the development of the "dark continent." American mining engincering has always been in great demand. Both at the time of the great diamond discovery in 1867 to 1870, and when gold was discovered about the year 1887, the lives of the people both black and white in this vast country were changed quickly by these activities. In this development the American engineer by reason of his experience, education and resourcefulness took a leading part, and the salaries ranged all the way from $\$ 15,000$ to $\$ 50,000$ with extras for group mining and consulting engineers. To-day the Transvaal with its gold mines employing 20,000 white skilled laborers and about 20,000 natives, furnish problems as well as possibilities for world trade. It is significant that never has the supply of labor for this industry exceeded the demand. Here al'e mixed populations such as few places of the earth present, Cornishmen, Dutchmen, barbarian nationalities, Britishers, and a great conglomeration of peoples from varied climes and of diverse racial strains.

While certain of the gold mines of the Transvaal are being abandoned as unprofitable, new ones are being opened and developed, chiefly on what is termed the East Rand. In spite of the fact of the increase in all costs of mining, together with Government taxation and restrictions, the price of an ounce of gold remains at the old standard and it is asserted by the mining companies that it costs 4 per cent to send bullion from the Transvaal to London, this including all costs.

Belgian Congo.-Northward from the Zambesi River to the Red Sea stretches the great eastern highland which reaches its most extensive development in the region about Victoria Nyanza. The average elevation of this highland 
is over 5000 feet except in Abyssinia where it rises over considerable areas to the height of 6000,8000 and 10,000 feet. The most significant feature of this region is the system of so-called rift-valley in which lic the majority of the great African lakes. In West Central Africa we find the Congo Basin which surpasses the area of the Mississippi Basin by 175,000 square miles. All of this area is an elevated plain which slopes gradually toward the middle west. The river Congo which, excepting the Nile, is the longest and largest in Africa, with its tributaries, not only drains nearly the entire territory but provides the main transportation facilities of this region.

Belgian Congo, formerly Congo Free State, was annexed to Belgium in 1907 with the king of the Belgians at its head. It is bounded on the north by French Equatorial Africa. Rubber is the chief product and export. Some of the other exports are ivory, raw gold, palm kernels, palm oil, raw copper, cacao and coffee. The chief imports are textiles, boats and machinery, beverages and foodstuffs. Copal, a resinous gum, is found in large quantities in the forests of the central Congo. This is used largely in the manufacture of varnishes and is especially valuable because it is liard and transparent. It is now being shipped principally to Antwerp. The exportation of copal from the Belgian Congo during recent years has been as follows: in 1916, 8677 tons; in 1917, 6940 tons; in 1918, 3636 tons. Copal is also an export of Portuguese Angola; all of the copal exported from Angola is sent to Portugal.

The United States, Great Britain and Japan are competing for trade in the Belgian Congo, especially in the Province of Katanga. This province appreciates particularly American wearing apparel of different kinds and this far-off market probably can be held by us in spite of the active competition of livals who have the advantage of being nearer than American houses.

Such things as textiles, enameled goods, tools, watches and locks are being sent to the district of Haut Luapula. Belgium naturally feels that it should have a larger share 
of this trade than it has been getting of late. Great Britain supplies eloth, sheetings, sugar, candles, tobacco and eigarettes. Japan took every opportunity during the war to ship those things which Germany had formerly sent and now supplies such merchandise as pencils, pocket and table knives, glassware, combs, mirrors, perfumery, matches and considerable quantities of colored cotton goods.

In this colossal country comprising almost evcry variety of nationality and offering extreme diversity of climate, the possibilities of the soil and the financial development of industries along a hundred lines, furnish the arena for world trade enterprises equal to the vision, the courage and the efficiency of merchant traders in all lands. It is significant that among American firms becoming intercsted increasingly in African business are those of the larger export and import houses. W. R. Grace \& Co. with their London offices have more or less flourishing offices and business activities in the following eities and towns of Africa: Alexandria, Accra, Freetown, Nairobi, Dakar, Johannesburg, Lagos-Nigeria, Bathurst, Bulama, Conakry. Among the products handled in these various sections are: cotton, cacao, palm oil, peanuts, or ground nuts, chrome and manganese.

We would recommend that all manufacturers or traders wishing to enter this vast open door of trade get in touch with the Bureau of Foreign and Domestic Commerce at Washington, D. C., which Bureau can supply latest information and statistics concerning any commodity. We would suggest in this, as in all cases where information is desired, that questions state definitely the products or definite line of industry about which information is desired, in order that this important Bureau may know exactly what information the manufacturer desires to obtain.

In the great trade field of the world, Africa is to tako an important place, being still a largely undeveloped, and in some places unexplored region that our trade pioneers "will go up to occupy." 


\section{CHAPTER XXIII}

\section{AMERICAN COMMERCE WITH RUSSIA}

The condition of Russia as this is written in 1921, characterized by great uncertainty as to promises held out by the Soviet government relative to trade, with little or no surety of protection for forcigners or foreign goods entering Russia, and with doubtful conditions of production or methods of payment on the part of the inhabitants of Russia, makes the present trade situation with this vast country a problematical one. The United States government justly has refused to have trade dealings with a government which possesses such a record as the present Soviet régime. In spite of rumors that certain trade with Russia is being done on the part of Great Britain and other European countries, it seems fairly safe to predict that this great country will be closed to world trade in general until other nations can become assured of a worth while government and a steadiness of production that will merit serious attention.

The following statement of Secretary of State Hughes made on March 25, 1921, in relation to the opening of trade between the United States and Russia, represents the attitude of the Government and of the leading and best informed business men:

The Government of the United States views with deep sympathy and grave concern the plight of the people of Russia and desires to aid by every appropriate means in promoting proper opportunities through which commerce can be established upon a sound basis. It is manifest to this Government that in existing circumstances there is no assurance for the development of trade, as the supplies which Russia might now be able to obtain would 
be wholly inadequate to meet her needs, and no lasting good can result so long as the present causes of progressive impoverishment continue to operate. It is only in the productivity of Rusisia that there is any hope for the Russian people, and it is idle to expect resumption of trade until the economic bases of production are securely established. Production is conditioned upon the safety of life, the recognition by firm guarantees of private property, the sanctity of contract and the rights of free labor.

If fundamental changes are contemplated, involving due regard for the protection of persons and property and the establishment of conditions essential to the maintenance of commerce, this Government will be glad to have eonvincing evidence of the consummation of such changes, and until this evidence is supplied this Government is unable to perceive that there is any proper basis for considering trade relations.

It is important, however, that Russia which has formed one of the greatest and most important markets of the world and which in all certainty possesses large prospective opportunities tor trade, when she puts her house in order, should receive the eareful attention of American business interests.

Russia, like India, for the American has been shrouded more or less in mystery. Although nominally included usually in Europe, this vast inarticulate land teeming with its millions of peasantry, its soil rich in every possibility of agrieulture and mining, partakes largely of Asiatic ideas and traditions. The vast distances, moreover, insufficient transportation, together with the geographical fact that Russia is not easy to reach by Americans, has added to the impregnability of this land for both trade and travel.

Added to these fundamental barriers to casy relationships are the present menace of Bolshevism and the terrific devastation and demoralization coming in the train of a great war. It would seem natural that the evils which this social and political Bolshevist movement has foisted on Russia-the evils of disi'upted homes, broken transportation, demoralized exchange and uncertain and unserupulous government-should discourage nationals of other parts of the world from engaging enthusiastically in Russian business. 
Previous to the war Germany held a monopoly of the Russian market. Comparing Russia's trade with Germany and with Great Britain it is found that from 1870 through 1913 Germany's export to Russia increased from 39.5 per cent to 52.6 per eent. Germany's export to Russia in 1913 amounted to $\$ 332,622,000$ - $\$ 246,300,000$ more than in 1870 . In the meantime England's export to Russia decreased from 31 per eent to 13.8 per cent.

The same is true of Russia's export to both countries. During these 43 years Russia's export to Germany increased from 21.1 per cent to 31.8 per cent. At the end of this period Russia's export to Germany had inereased $\$ 176,100,000$. During the same time Russia's export to England dropped from 47.2 per eent to 18.8 per eent.

According to the statement made by Mr. A. J. Saek, Director of the Russian Information Bureau in the United States, a great part of Germany's suecess in Russia was due to the Russian-German Commereial Treaty existing before the war. 'This treaty favored German interests to such a degree that before the war, in Russian economic literature, the question was raised, as to whether Russia should be Germany's colony any longer? But the RussianGerman Commercial Treaty was only one of the conditions that made for Germany's success in dealing with Russia. The immediate reason for Germany's suecess was her wonderful method in trading.

It was generally considered that English goods imported into Russia were better in quality than German goods, but the English made the mistake of not considering the eomparatively low buying power of the Russian population. English goods, like American goods, were always high priced and did not present as great variety and novelty as German produets.

Another difficulty that England as well as the United States has experienced in competition with Germany, lay along the line of eredit. The English contracts with Russian houses were elosed f.o.b. English port. This was contrary to the customs of the Russian market where the credit 
system was used largely in the purchase of goods. This demand to pay for goods a month or two before the goods were even sent was fatal to English trade with Russia.

The Germans were most generous in their credits and furthermore the German salesmen spoke Russian fluently and presented their catalogs printed in Russian, marking their goods according to the Russian system of measuring with prices marked in rubles and liopeks.

Even during the war Germany kept up certain connections with Russia through neutral European eountries, sometimes by masquerading their industrial products under French, English, Swedish and Japanese names. It was, therefore, to be expected that the Allies after the war should expect Germany to secure as soon as possible her old preëminence in trade with Russia, and shortly after the Armistice it was reported by a member of the American Commission in Berlin that the Germans had planned to send a Commission to Russia for the purpose of examining the economic conditions of that country. In this report it was stated that Germany had pledged herself to reconstruct the railroads and telegraphic system of Russia, as well as to export a certain amount of machinery for agricultural and industrial purposes. However true this report may be in detail there is no doubt of the fact that Germany is especially well equipped for trade with Russia for three reasons: Favorable geographical position; low rate of exchange plevailing in both countrics; and the fact that a considerable portion of German industry, particularly the steel and iron industries which have been exporting to Russia for many decades, has a elear knowledge of Russian needs.

The United States in the future, however, will meet not only German competition but must cope with most active energies on the part of England, France and Japan, which countries already have had economic connections in Siberia and are watchful for the future openings of trade wherever the demoralizing Soviet Government gives opportunity for 
entrée. Canada has studied the Siberian markets, and prospects, and Japanese merchants and bankers have acquired leaseholds on industries, forests and mines in Eastern Siberia.

If population, soil, mineral deposits and business generally have to do with future success of trade, Russia must be considered as one of the great future possibilities for commerce and trade development. Russia's economic progress depends upon the development of her vast natural resources and the reëstablishment of Russian credit in foreign markets, with the repudiation of Bolshevism. These, naturally, are the first essentials toward the enlarging of her markets.

The Russian Information Bureau in the United States points out the striking development even under the bureaucratic régime during the ten years preceding the last war. During this period Russia's national wealth had almost doubled. Before the Russo-Japanese War in 1901, Russia produced 16,750,000 tons of coal. 'Ten years later, in 1911, Russia yielded $31,116,667$ tons of coal, about 86 per cent more than in 1901. Just before the World War Russia was producing more than 40,000,000 tons annually. The amount of copper smelted in Russia in 1901 was only 9633 tons. In 1911 this amount had increased to 26,060 tons. Just prior to the war it totaled about 40,000 tons. The progress in copper production is analogous with the development in all the metallic industries in Russia. The quantity of pig iron produced was almost doubled in three years, reaching more than $5,000,000$ tons just before the war.

Agricultural production in Russia developed along the same lines. In 1901 an area of 214,500,000 acres was sowed in main agricultural products, whereas in 1910-1911 the number of acres planted was $246,000,000$. The yield in 1901 was 54,167,000 tons, and in 1910-1911 it amounted to $74,168,000$ tons.

Naturally, with the development of Russia's industries, Russia's trade also developed. 'The number of Russian commercial houses increased from 862,000 in 1901 to $1,177,000$ 


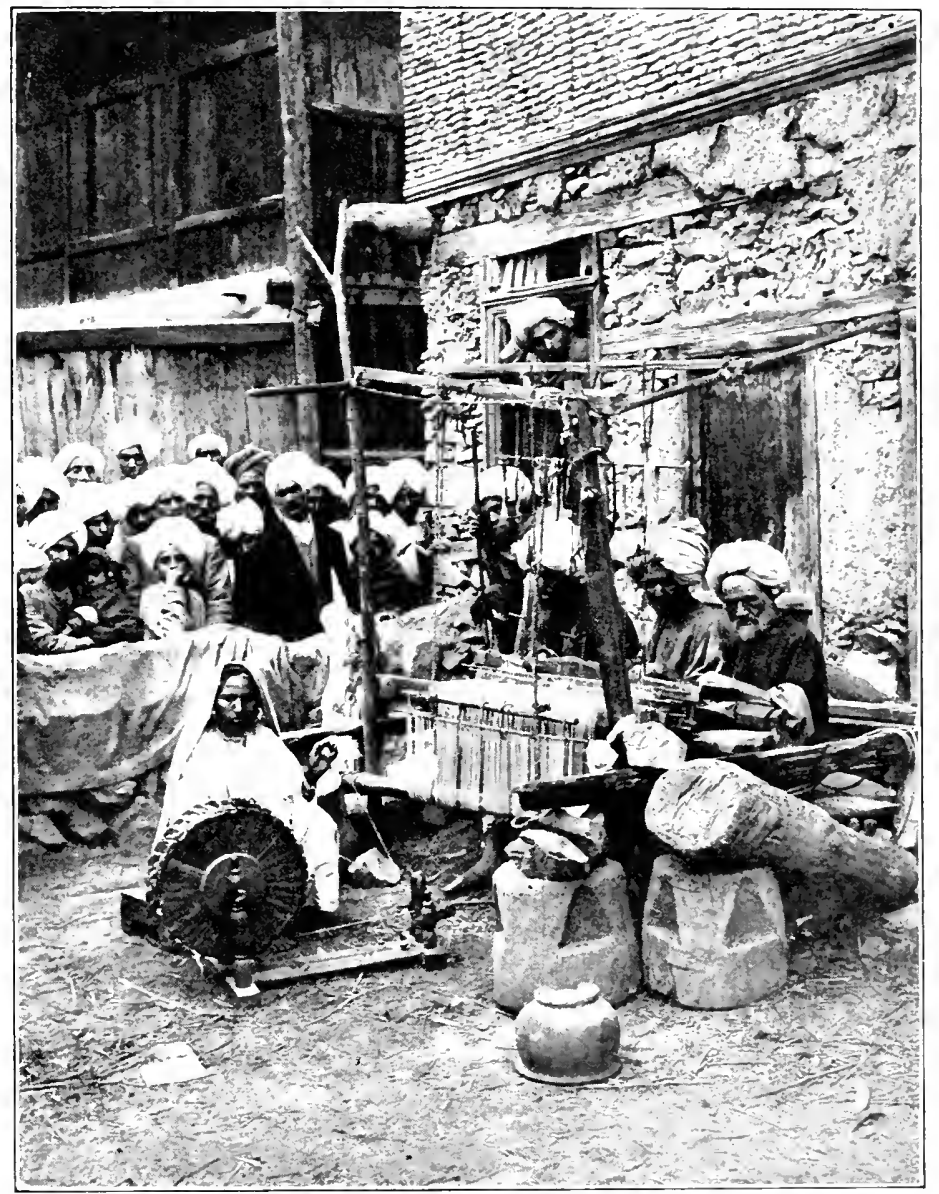

copyright, Publishers Photo sirtice, X. Y

FPINING WOUL AND WEAIINA CASIIMERE SIIWLS AT MYRIAGAR, CASHMERE, NORTH INDIA. 


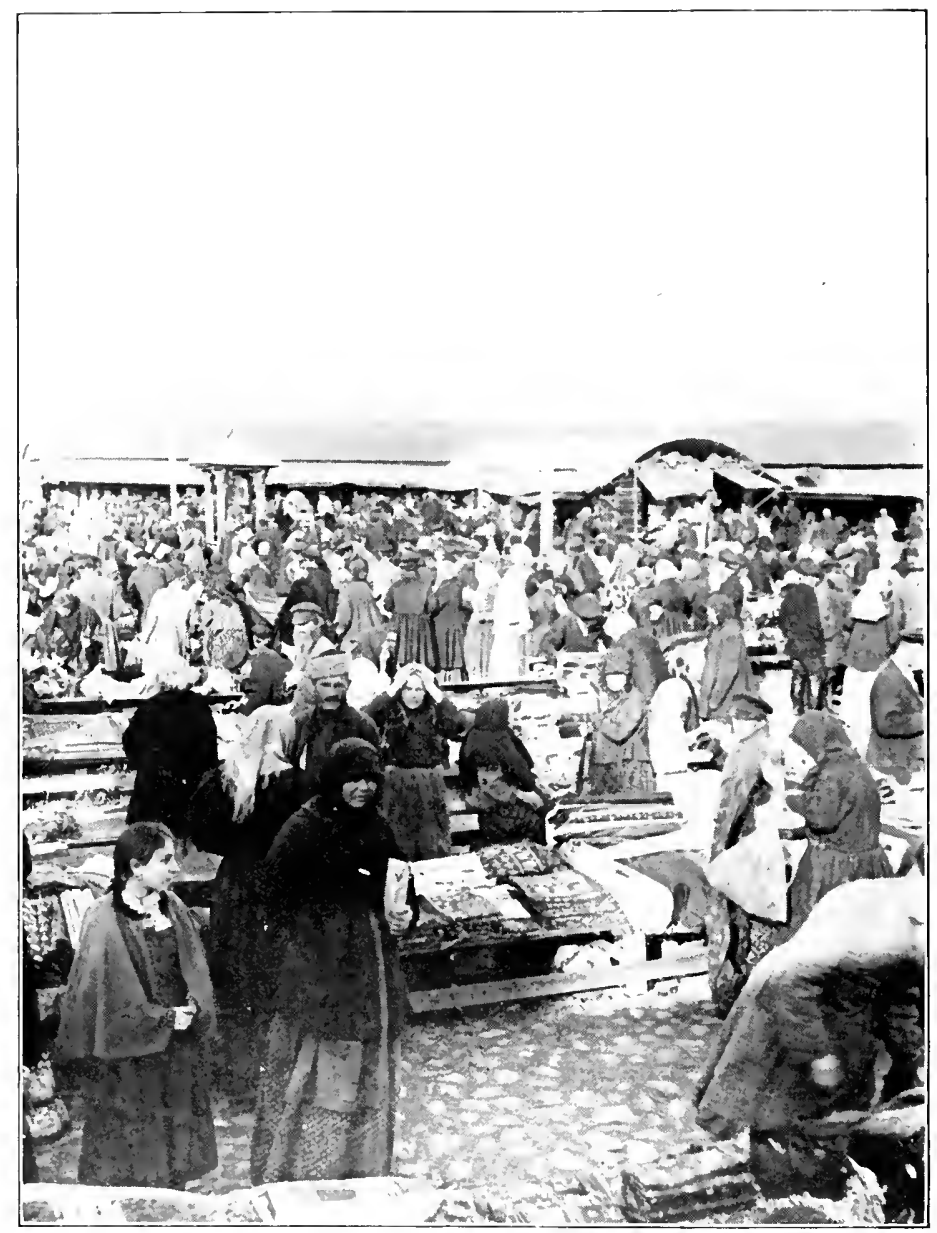

copyright, I'nderwood \& I'nderuood, N. Y.

RUSSHAN CLOTH MARKET IN "THE FAIR" OF NIJNI NOVGOROD, RUSSIA. 
in 1911. Just preceding the war the number of eommercial houses totaled about 1,500,000.

The joint stock company is a very important feature of Russia's industrial development. Many Russian manufacturing establishments are organized in the form of joint stock companies. During the five years 1903-1907, 419 joint stock companies began operating in Russia, with a eapital of $\$ 180,540,000$. During the following five years, 1907-1911, 778 joint stock companies were operating with a capital of $\$ 453,900,000$. Just prior to the war, in 1913, 235 new joint stock companies were organized, with a capital of about $\$ 204,000,000$. The eapital of the joint stock companies inereased about $\$ 500,000,000$ since 1911 , reaehing a total of $\$ 2,022,150,000$ before the war. Of this $\$ 299,370,000$ was foreign eapital.

Simultaneously with the striking economie and commereial development in Russia, the financial strength of the vast country greatly increased. The money in Russian banks and in circulation multiplied from $\$ 918,000,000$ to $\$ 1,938,000,000$ during the ten years prior to the war, an increase of about 111 per cent. The amount of securities in cireulation grew from $\$ 4,233,000,000$ to $\$ 6,783,000,000$, an inerease of about 60 per cent. The deposits in the Russian State Bank, Societies for Mutual Credit, commereial banks and eity banks on January 1, 1913, amounted to $\$ 1,669$,230,000 about $\$ 1,000,000,000$ more than on January 1, 1903 . The deposits in the Russian savings banks multiplied from $\$ 399,840,000$ in 1903 to $\$ 812,840,000$ in 1913 . During the ten years between the Russo-Japanese and the present war Russia's wealth had doubled.

One of the first needs of Russia is the development of her railroads. Russia, covering one-seventh the total area of the globe and being about three times the size of the United States, possesses only about 40,000 miles of railroad. The following table gives a eomparison of the pre-war railroad situation in Russia, not only with that of the United States but also with the principal eountries of Europe: 


\begin{tabular}{|c|c|c|c|}
\hline & $\begin{array}{l}\text { The Length } \\
\text { of the Rail- } \\
\text { road System } \\
\text { (in miles) }\end{array}$ & $\begin{array}{c}\text { To Each } \\
100 \text { Square } \\
\text { Miles }\end{array}$ & $\begin{array}{c}\text { For Every } \\
10,000 \\
\text { Population }\end{array}$ \\
\hline 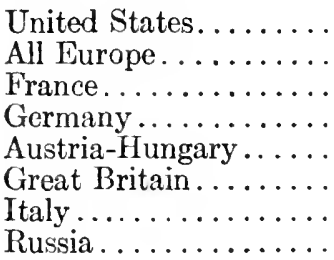 & $\begin{array}{r}258,783 \\
225,898 \\
32,924 \\
40,766 \\
29,582 \\
25,053 \\
11,304 \\
39,706\end{array}$ & $\begin{array}{l}1.9 \\
1.5 \\
4.1 \\
5.0 \\
2.9 \\
5.3 \\
2.6 \\
0.5\end{array}$ & $\begin{array}{r}29.0 \\
5.0 \\
8.4 \\
6.2 \\
5.8 \\
5.6 \\
3.2 \\
3.2\end{array}$ \\
\hline
\end{tabular}

Russia also needs coal in order to develop her mining in the Ural Mountains, as there is practically no coal in these mountains. This coal must be brought from Western Siberia, and the problem of transportation is one of the difficulties connected with the industrial development of the country.

The development of Russia's timbei industry holds a key to the partial solution of her financial difficulties, since Siberia contains half the forests of Asia. It is estimated that in the Amur region and in the Maritime Province alone there are 509,000,000 acres of timber land. During the nineteenth century, Russia's timber export multiplied 126 times and she is destined to take a leading place in the world's markets in this commodity.

Comparing Russia with a group of countries which are able to export timber, gives the following results:

\section{The Amount of Timber Land (in Acres)}

Germany ....... 38,430,000

Balkan States..... 28,380,000

France (without col-

onies) .......27,141,000

Spain (without colo-

nies) ........ 17,844,000

Italy (without colonies) ......... 11,256,000

Great Britain (with-

out colonies)... $3,375,000$

Other European

countries......6.6, 626,000
Russia . . . . . . 1, 125,000,000

Canada ......... $889,380,000$

United States. . . 6 603,000,000

Scandinavia.... 81,000,000

Austria-Hungary. $\quad 63,000,000$ 
In spite of Russia's great preserves in this line she has been behind other nations in the amount of foreign trade in timber as the following statistics of the export of timber in 1913 from Russia show :

\begin{tabular}{|c|c|c|}
\hline & $\begin{array}{l}\text { The Amount of } \\
\text { Timber Land } \\
\text { (in Acres) }\end{array}$ & $\begin{array}{l}\text { The Export of } \\
\text { Timber } \\
\text { (in Dollars) }\end{array}$ \\
\hline 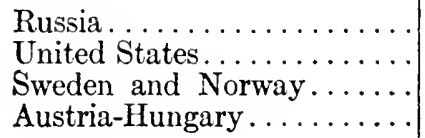 & $\begin{array}{r}1,125,000,000 \\
603,000,000 \\
81,000,000 \\
63,000,000\end{array}$ & $\begin{array}{r}89,250,000 \\
134,487,000 \\
129,489,000 \\
79,203,000\end{array}$ \\
\hline
\end{tabular}

In a great agricultural country like Russia containing potential wcalth and population far greater than that of our original Ameriean colonies, no government conditions can be lastingly a menaee to her prosperity ; no government, however bad, can destroy the fertility of her soil or the wealth locked up in her mines, or her forests. In these three great resources alone Russia will one day rise in a gigantie strength.

Russia is Europe's granary and Central Europe obtained before the war one-third of her staple food requirements in Russia. In the year 1913 Russia produced onethird of the world's wheat, one-half of the barley and 90 per cent of the flax. The country holds a balance of ceonomic power in Europe and the safety of Europe, as well as the stability of world economic conditions depends more largely upon this country than we sometimes suppose. The world's body eannot grow continuously strong and healthy with a diseased member, especially when that member is so enormous as Russia.

Bolshevism which has out-czared the Czar must come to an end or be radically reformed before the world will again establish its real equilibrium. The whole earth needs Russian furs, meats, hides, her coal, her iron, her manganese, her eopper, her timber and her agricultural products, and 
one naturally asks-How can this most speedily be brought about?

Already some progress has been made through the use of the Russian coöperative societies and in Sibcria a system akin to barter, especially in the trading of furs, has been carried on. The commercial accounts of Russia were usually all right before the war and there is no reason to distrust Russian business men along this line as soon as present political upheavals have subsided.

One of our reasons for failure in Russia according to Mr. Frederick M. Corse, Vice President New York Life Insurance Company, has becn our initial error in sending inferior men to represent us.

Since 1902 I have witnessed scores of failures. Many representatives of American business houses have gone there, men of untried character, who suffered a moral collapse inside of a year. An equally unfortunate class of men came, loud and blustering men who failed because they had no experience in handling delicate situations where tact and patience were neccssary, men who could not respect and honor customs and formalities alien to our own. During the last five years a marked improvement has been noticeable. Younger men were sent under careful supervision, enforced to learn the language and eustoms of the country before assuming heary responsibilities. Only in this slow and conservative way can permanent and profitable commerce between America and Russia be built np.

As far as labor is concerned, in Russia it is a simple problem as compared with labor in certain other parts of the world. Labor costs per unit of product in Russia are below those in the United States. Usually, eren in the use of labor a certain knowledge and adjustment to the country's conditions are required if Americans are to succeed.

Social etiquette must be studicd as in other foreign lands and the regular customs concerning handshaking, going without breakfast, and tea drinking, necd to be observed. As in Japan, a business call is a social event. 
Mr. Norton, Acting Director, Russian Division United States Committee on Public Information, has given some valuable suggestions for our business leaders who are choosing men and training them to send to Russia when the new day of trade dawns:

Your agent should be sent to Vladivostok or Harbin at once. He should be a young man, and he certainly should be an American. Far too long have we permitted foreign 'nationals' to represent us in world trade. Our Russian business has been in the hands of Germans and Swedes. This policy is particularly dangerous in the Far East where all business is based on personal friendship, where your customer's are not your friends, but your agent's friends, and therefore his customers. Should he leave you at any time, your eustomers will go with him. If he owes allegiances to any other nation, sooner or later he will deliver your business to his own country. It is surprising to note how many American agencies in the Far East are in the hands of representatives from other countries.

Living conditions are difficult in Siberia at this time, and young men will bear them with greater cheerfulness than could an older man. Expensive outfits are not required in preparing for a winter in Siberia. Any man in ordinary American elothing is sufficiently warmly clad to live in Siberia in the dead of winter, provided only that he have a fur, a warm top coat, cap, gloves, blankets, linen, eigarettes, and such personal necessities of life as he would use here, remembering only that he will buy nothing other than food in Siberia. He should take some knives and fountain pens to be used as gifts, and he should have warmer underelothing than B.V.D.'s. Last winter one of our young men wintered in Omsk with only such garments in his wardrobe, and he is still gunning for his advisor.

A young man should be sent because he will be more tolerant of foreign customs, and why should not the Americans be tolerant? In the eyes of the Far East, we are a young nation. Our older neighbor's generously give us credit for many improved customs, but why should we be intolerant of the well tried customs of other nations, especially when we are so young in trading with the world that we do not have the slightest conception of the reasons why eertain things are done in certain ways? We laugh at the Russian's 'tea-drinking' during the day. We are 
amused that the Samovar is kept hot for the manager and clerks. The reason for this custom-like the answer to all customs-is simple. The water in Russia is unfit for use until boiled; boiled water without tea or other flavoring is flat.

But our young friend will find that the same spirit which mado him successful here will make him successful over there, despite the bewildering maze of odd conditions, provided he adds to his Americanism a certain degree of reserve and patience, and still more patience, not forgetting entirely that $A$ merican energy, persistence and resourcefulness, are of great value to him wherever he is. The American that goes to Siberia will find that a little more attention to formal etiquette and tactfulness will pay big dividends. In other words, he should make himself a more perfect American, rather than forget that he is an American. He should not try to become a Russian, or a Japanese, or a Chinese.

As to when Russia will again be opened for successful and satisfactory world trade, it is difficult to predict at this writing. It would seem impossible, however, for the present régime to continue in Russia for any great length of time since the country must produce, must establish and complete its transportation facilities and make provision for the safety of life and property, if the nation is to go on and take its part in world trade relationships. When this new and brighter day dawns for Russia, it would seem reasonable that Americans who have given thought and preparation to the possible trade routes to Russian markets, and to a study of the Russian language, would be able to secure their share of business in this vast territory, certain to become through the richness of its potential resources onc of the great producing, exporting and importing countries of the world. 


\section{CHAPTER XXIV}

\section{MARKFTS WITH THE UNITED KINGDOM, CANADA AND AUSTRALIA}

The United Kingdom of Great Britain and Ireland may be ealled "the mother of foreign commerce."

Even before the rapid rise of American industrial activity in the latter part of the nineteenth century, when none of Britain's present eompetitors for world eommerce lad become formidable, the United Kingdom was firmly established in a trade that reached virtually every corner of the earth.

By her merehant marine, by her policy of vast investnents abroad which brought her reciprocal trade, by her free trade policy, as well as by her great manufacturing genius and her colonizing eapacity, Great Britain had gained a material empire upon which the sun never set. When you thought of foreign trade for any country before the World War, it was England which first eame into thought. In 1913 she possessed one-sixth of the entire trade of the world, a commerce amounting to over $\$ 6,800$,000,000 , a trade at least $\$ 2,000,000,000$ in advance of Germany, who was then her nearest rival.

When the European war broke out in 1914, England possessed practically one-half of the ocean tommage of the world, as well as being the leading shipbuilding nation and underwriting two-thirds of the marine insuranee on the world's output of ships. Although she ranked seeond to the United States in the manufacturing industry, her investments of eapital in foreign enterprises were the largest of any nation, while she was the confessed leader of the world in banking and finance.

In all this development, England's coal supply, which 359 
was one-fourth of the entire coal production of the world, gave her great assistance, not only in her own manufacturing, but in the fact that she could readily supply return cargoes for her ships to nonproducing coal countries.

Among the reasons which gave Great Britain her great prestige in commereial trading was the fact that her trading pioneers, no matter where they were found, always had the assurance that their rights and their property would be safeguarded by the diplomatic, the military and the naval power of Great Britain, a confidence, by the way, which has not always been present among American business men who have gone forth to invest capital and labor in building up foreign business.

A natural love for the sea and for adventurous exploits was another reason for England's foreign trade success, while the geographical position of the British Isles made it essential for her to look bcyond her own borders for expansion. There has always been notable among the British a farsighted and settled policy in connection with their forcign business. One feels in India, for example, that viceroys and governors may come and go, but in the background there is always, not only the English Constitution but a trade policy, a policy that is not at the merey of frequently changing parliaments and which has been worked out through ycar's of successful commercial efforts.

England has also cultivated the habit of placing her trade routes, trading and coaling stations, at strategic points in the world, and she has also made her country a distributing center for the products of other nations. She became, naturally, a great world market and London was looked upon for several centuries as both the commercial and also the financial center of the entire world.

It is only through the exigencies of the war that the United States has usurped something, particularly of the finaneial prestige, of the United Kingdom, but the trade relations between these two English speaking countries are among the most important factors in the entire circle of overseas commerce. 
A study of markets relating to Great Britain and the United States and a knowledge of the important exports and imports between the two nations are important factors for the American trader to know if he expeets to build up a permanent commeree in any partieular line with Britishers. It is important to know that our trade with the United Kingdom (England, Scotland and Ireland), during the year 1920 amounted to the rast sum of $\$ 3,320,434,238$ (conversion based on normal rate of 4.8665 dollars to the pound sterling), and that the leading articles in this commerce were:

\section{Exporti; fron the LNITHD Sitates}

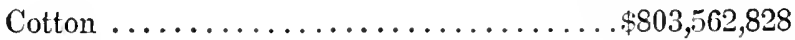

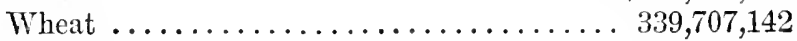

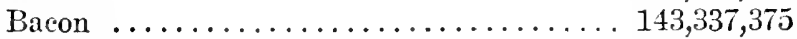

Tobaceo ................. 135,716,830

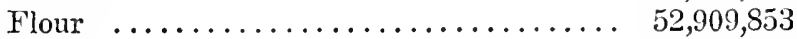

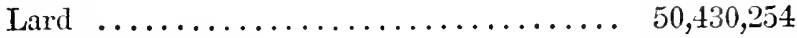

Hides and Leather .............. 41,365,708

Barley .................... 36,653,708

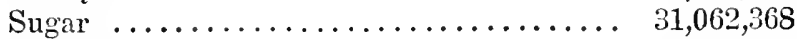

Copper . .................... 19,466,000

Iron and Steel .............. 14,599,500

\section{IMPORTS INTO L'Nited STATES}

Cotton piece goods . . . . . . . . . . . \$38,932,000

Rubber .................... 30,600,000

Linen piece goods . . . . . . . . . . 29,834,297

Woolen and worsted yarns and mfos. (except

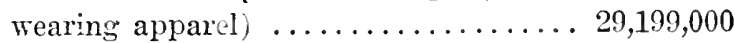

Cotton varns ................. 26,489,471

Precious stones ................. 22,500,000

Jute piece goods, bags, ete. . . . . . . . . . 19,466,000

Furs ...................... 18,800,000

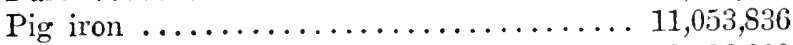

Hides and skins .............. 9,733,000

Leather . . . . . . . . . . . . . . . . $7,305,983$

Tin $\ldots \ldots \ldots \ldots \ldots \ldots \ldots \ldots \ldots \ldots \ldots \ldots \ldots \ldots \ldots \ldots \ldots$ 
The total trade was made up of $\$ 2,746,340,353$ exported from the United States to Great Britain and $\$ 574,093,885$ exported from Great Britain to the United States, or approximately a ratio of exports to imports of 4 to 1 in favor of the United States. However, imports from Great Britain in 1919 were only $\$ 375,866,513$, showing that Great Britain increased her exports to us in the space of one year by $\$ 198,277,372$. Exports of gold bullion and coin by the United Kingdom for 1920 amounted to $£ 92,565,137$ ( $\$ 450$,$468,239.21)$ of which $£ 80,621,469(\$ 392,344,378.89)$. was in refined bullion bars and the balance in coin. Of this $£ 80$,621,469 of gold bars, $£ 52,828,093(\$ 267,087,914.58)$ was exported to the United States.

It is important also to have somewhat precise knowledge as to the tendency of British trade in South America where for many years Englishmen and Scotchmen particularly have devoted much attention to the development of British markets. In 1920 British trade with South America amounted to $₫ 79,872,574$ ( $\$ 386,699,882.37$ ) of which $£ 52$,$139,433(\$ 253,736,550.69)$ were exports and $£ 27,733,141$ $(\$ 134,963,430.68)$ were imports, while the trade of the United States with the same section during the same period was $\$ 1,384,964,034$ of which $\$ 623,910,163$ were exports and $\$ 761,053,871$ were imports.

The manufactures of England which have been particularly notable in world trade have been textiles, especially those of cotton, together with machinery used in the textile industry, and leather manufactures, shipbuilding and the production of locomotives, iron and steel rails, pottery and cutlery.

It is interesting to note that the value of English manufactures exported in 1912 amounted to $\$ 2,000,000,000$, while that of all other nations amounted to $\$ 6,000,000,000$. In 1913 it is estimated by a prominent British statistician that the investments of Englishmen in overseas property aggregated $£ 3,715,000,000$ or about $\$ 18,000,000,000$, and that her investments in the United States were estimated at $£ 755,000,000$, and investments in Latin America aggregated $₫ 724,000,000$. 
It is this practical farsightedness of Great Britain which has helped to establish her so firmly in virtually every part of the world.

Professor William Clarenee Webster is quoted as follows relative to this subject by Messrs. L. C. Ford and Thomas F. Ford in their excellent treatise on The Foreign Trade of the United States:

While England has been losing her position as the world's workshop, she has been building up her capitalistie supremacy. Her eapital has flowed into her colonies and nearly every country in the world. Consequently she has become the world's creditor, and wields the power that accompanies capitalistic supremacy. Her capitalists own vast tracts of land and work farms in nearly every country of the world; they also control railroads, manufacturing plants, and mines in many of the most strategie places on every continent. In this way England keeps her cows in Australia, Canada, and Argentina; cultivates her wheat in Manitoba, the United States, and India; grows her cotton in the United States, India, and Egypt; spins it not only at home, but even in India, China, Egypt, and Mexico; makes her machinery in Germany and the United States. Thus not only her many colonies, but the whole world has become a part of her domain through the power of her eapital.

No one ean travel in Argentina, for example, where such enormous British investments are everywhere evident, especially in Argentina railways, without appreeiating how strategic it is for nations to show their belief in foreign commerce by investing their money in the projects intended to develop the foreign countries.

In general, it may be said, that the United Kingdom of Great Britain imports foodstuffs, raw materials for her factories, and eertain manufactured silks, leather, woolen, hardware utensils and machinery.

Among the foodstuffs are dairy products, tropical fruits, tea, coffee, sugar and eocoa, while the raw materials include cotton, wool, hides, iron ore, skins and lumber. Her 
exports for the most part are included in such large items, as manufactures of iron and steel, coal, woolens, cotton and chemicals.

Great Britain has become past master in trade procedure relative to credits, open accounts, packing, financing and shipping her goods, and behind all this methodic equipment and experience she has placed a rare business integrity and gradually built up her foreign markets upon an unusual aptitude for international trading.

Whether in the immediate years the United Kingdom will be able to make any such huge investments in foreign enterprises as has been her custom in the past may be doubted. Nevertheless, it may be taken for granted that in such sections as Latin America, South Afriea, China and India, the firm basis of trade and finance built up for generations by English industry and English capital will stand firm, and wherever overseas commerce exists it can be taken for granted that the United Kingdom of Great Britain will be found taking her legitimate share of responsibility in developing new countries and at the same time enlarging the circle of her commercial influence.

Canadian and Australian Markets.-As a market for American goods Canada stands a good third, trade between Canada and the United States being exceeded only by the United Kingdom (British Isles) and by Latin America (South and Central America). With her 9,000,000 people, with her natural wealth of $\$ 17,000,000,000$, our neighbor to the North has become naturally closely united to us in the bonds of commerce?

In her broad Western areas particularly, Canada has had similar problems and similar successes to our own in agriculture, lumbering and the general development of her new continent.

More truly perhaps than any section of her mother country, the Canadian people understand Americans and the 3000 miles of unguarded boundary between the two countries is an imaginary line.

Canada's assets include chiefly her agkicultural resourees, 
her forests, her fisheries and her mines. Our dependence upon Canadian wood pulp from which paper is manufactured was brought elearly to the attention of American people during and after the war, and Canada's broad western fields of wheat, barley and oats rival any other parts of the world in the cultivation of such products.

British Columbia has an estimated forest area of $50,000,000$ acres and produces all merehantable woods and pulp woods. Quebce, with 100,000,000 acres of forest, has the largest timber area in Canada, and is the largest producer of pulp wood. Alberta has 11,800,000 acres of forests producing spruce, pine, cotton-wood and poplar. Manitoba has about 10,000 square miles, produeing prineipally spruce. Nova Scotia produces spruce, fir, hemlock, pine, oak, maple and birch on about 8000 square miles. Ontario, with $70,000,000$ acres of forest area, produces spruce, pine and poplar. The Yukon has large tracts of both white and black spruce, balsam, poplar and birch. The forest area of Prince Edward Island is about 316,000 acres.

According to the report of Consul Felix S. S. Johnson of Kingston, Ontario, on June 26, 1921, Canada's imports of merchandise for the fiscal year ended March 21, 1921, had an aggregate value of $\$ 1,240,158,882$, this total comparing with $\$ 1,064,528,123$ in the previous year, $\$ 919,711$,705 in 1919 , and $\$ 619,193,998$ in the pre-war year of 1914 . Exports of domestic merchandise from the Dominion amounted to $\$ 1,189,163,701$, as compared with $\$ 1,239,492$,098 in $1920, \$ 1,216,443,806$ in 1919 , and $\$ 431,588,439$ in 1914. The trade balance for each of these years is shown in the table on page 366 .

This calculation takes no account of the reëxports, which amounted to $\$ 23,848,785$ in the fiscal year $1914, \$ 52,321,479$ in $1919, \$ 47,166,611$ in 1920 and $\$ 21,264,418$ in 1921 . 'The inclusion of these sums changes the trade position as follows: $1914, \$ 163,756,774 ; 1919, \$ 349,053,580 ; 1920, \$ 222$,130,$586 ; 1921, \$ 29,730,763$. 


\begin{tabular}{|c|c|c|}
\hline Classification & 1914 & 1919 \\
\hline $\begin{array}{l}\text { Imports. } \ldots \ldots \ldots \ldots \ldots \ldots \ldots \ldots \ldots \\
\text { Exports. } \ldots \ldots \ldots \ldots \ldots \ldots\end{array}$ & $\begin{array}{r}\$ 619,193,998 \\
431,588,439\end{array}$ & $\begin{array}{l}\$ 919,711,705 \\
1,216,443,806\end{array}$ \\
\hline $\begin{array}{l}\text { Excess of imports }(+) \text { or ex- } \\
\quad \text { ports }(-) \ldots \ldots \ldots \ldots \ldots\end{array}$ & $+187,605,559$ & $-296,732,101$ \\
\hline Classification & 1920 & 1921 \\
\hline 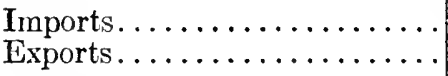 & $\begin{array}{r}\$ 1,064,528,123 \\
1,239,492,098\end{array}$ & $\begin{array}{r}\$ 1,240,158,882 \\
1,189,163,701\end{array}$ \\
\hline $\begin{array}{l}\text { Excess of imports }(+) \text { or ex- } \\
\text { ports }(-) \ldots \ldots \ldots \ldots \ldots\end{array}$ & $-174,963,975$ & $+50,995,181$ \\
\hline
\end{tabular}

Imports from the British Empire for 1921 aggregated $\$ 265,911,222$, contrasted with $\$ 174,351,659$ for the preceding ycar; for the same periods imports from continental United States (exclusive of Alaska) amounted to $\$ 856$,613,430 and $\$ 801,097,348$. On the other hand, exports to the British Empire declined from $\$ 561,788,003$ in 1920 to $\$ 403,470,602$ in 1921 , while exports to the United States increased from $\$ 464,028,183$ to $\$ 542,304,456$. The major divisions of Canada's import and export trade for the fiscal year ending March, 1921, compare with 1920, 1919 and the pre-war of 1914 as indicated in the table on page 367 .

Among foreign countries Cuba, France, Switzerland, Japan and San Domingo followed the United States in rank as suppliers of the Canadian market; and, next to the United States, Italy, Belgium, France, Greece and the Netherlands were the Dominion's best "foreign" customers last year.

Australian Markets.-Another of the British dominions requiring the attention of American exporters and manufacturers is the commonwealth of Australia with its vast total area of 2,946,691 square miles, a rich and growing land of opportunity, in some respects similar to Canada in 


\begin{tabular}{|c|c|c|}
\hline Classification & 1914 & 1919 \\
\hline $\begin{array}{l}\text { IMPORTs } \\
\text { British Empire } . . \ldots \ldots \ldots \ldots \ldots \ldots \\
\text { United States. } \ldots \ldots \ldots \ldots \ldots \ldots \\
\text { Other countries. } \ldots \ldots \ldots \ldots \ldots\end{array}$ & $\begin{array}{r}\$ 154,526,846 \\
396,302,138 \\
68,365,014\end{array}$ & $\begin{array}{r}\$ 123,671,540 \\
750,203,024 \\
45,837,141\end{array}$ \\
\hline Total imports... & $\$ 619,193,998$ & $\$ 919,711,705$ \\
\hline $\begin{array}{l}\text { Exronts } \\
\text { British Empire } \ldots \ldots \ldots \ldots \ldots \\
\text { United States. } \ldots \ldots \ldots \ldots \ldots \\
\text { Other countries. } \ldots \ldots \ldots \ldots\end{array}$ & $\begin{array}{r}\$ 238,642,517 \\
163,372,825 \\
29,573,097\end{array}$ & $\begin{array}{cc}\& \quad 605,159,789 \\
454,873,170 \\
156,410,847\end{array}$ \\
\hline Total exports. & $\$ 431,588,439$ & $\$ 1,216,443,806$ \\
\hline Classification & 1920 & 1921 \\
\hline 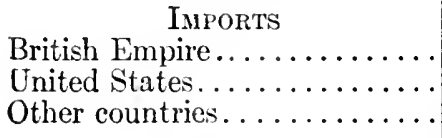 & $\begin{array}{r}\$ 174,351,659 \\
801,097,318 \\
89,079,146\end{array}$ & $\begin{array}{r}\$ 265,911,222 \\
856,613,430 \\
117,634,230\end{array}$ \\
\hline Total imports.. & $\$ 1,064,528,123$ & $\$ 1,240,158,882$ \\
\hline 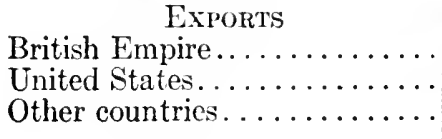 & $\begin{array}{l}\$ 561,7 S S, 003 \\
464,028,183 \\
213,675,912\end{array}$ & $\begin{array}{r}\$ 403,470,002 \\
542,304,456 \\
243,388,643\end{array}$ \\
\hline Total exports. & $\$ 1,239,492,098$ & $\$ 1,189,163,701$ \\
\hline
\end{tabular}

progressiveness and also sympathetically related in the character of the people to the inhabitants of the United States.

Here is a great sheep and cattle land producing minerals of gold, coal, silver, copper and iron in large quantities, and also a manufacturing country, particularly in the states of New South Wales and Victoria.

In this fertile continent of new wealth, sheep-raising las comprised one of the most important of the pastoral industries, and wool has been the most important single article 
of exchange. The cattle and horse-breeding industries have also been vital in Australian commerce.

Another industry of great importance is that of the growing of wheat, corn and the cultivation of such products as hay, potatoes, sugar cane and fruit.

Australia is one of the greatest gold-producing countries in the world and silver is also mined extensively. There are also iron and coal mines, and mineral products such as manganese, bismuth, lead, mercury, wolfram, nickel and zine are found.

The United States in a recent year supplied about 25 per cent of the total imports of Australia and purchased approximately 15 per cent of the total exports.

This country, carrying on a foreign trade aggregating considerably above the half billion mark is ccrtain to be more and more closely associated with American markets and with the advantages of the new American shipping routes, identical language and the gencral similarity of problems, the cordial trade relations between the United States and this great commonwealth should be steadily developed. 


\section{CHAPTER XXV}

\section{UNDERSTANDING BRITISHERS-A NECESSITY FOR SUCCESSFUL INTERTRADE RELATIONS}

A foreign country is a point of comparison wherefrom to judge our own.-Emerson.

Quite as important as the knowledge of markets, and a subject which is far less frequently eonsidered, is a thorough-going knowledge of English traits and the ability to compare Ameriean and English charaeteristies of doing business. This knowledge is fundamental and elemental to suceessful business dealing. We, therefore, wish to present a study of these contrasting traits and to add that the manufacturer or merehant who has been able to grasp the outstanding eharacteristies of the British character and adapt himself to them has progressed a considerable distance beyond any eompetitor who endeavors to do business with Britishers without this rudimentary knowledge.

It was about thirty years ago that Matthew Arnold, after his visit to Ameriea, wrote in the Nineteenth Century, saying that, as he viewed them, our dangers as a nation are "self-glorifieation and self-deception." These traits ho attributes to "the predominance of the common and ignoble, born of the predominanee of the average man." The seareh of the English eritie for the "sense of elevation" was unsatisfaetory, and reveals among other things the diffieulty of the foreigner to get at the real America.

Lord Haldane gave utterance before the World War to the thought that the great danger threatening a rupture in the 
relations between Germany and the United Kingdom lay in the fact that owing somewhat to a common origin each nation imagined that it understood the other. The lamentable blunders shown before the eyes of the world in the World War in the mistaking of motives and ideals of peoples closely united by the tics of blood and marriage, and even with adjoining territories, lead to the conviction that there is something inalienable and racially inherent in the warp and woof of every people, which in a sense is not translatable, especially to a foreigner; something which even the native who feels it intuitively finds it most difficult to express.

In spite of the cementing ties between the English and the American, and notwithstanding the usual talk of " "motherland," these two countries are, in the realm of national characteristics and ideals, worlds apart. While one senses certain truth in the criticism of a great English critic like Arnold, even though that criticism is more than a quarter of a century old, there is yet a feeling that the real spirit of America has escaped him. Americans have been well supplied with books written by our cousins across the seas, and have seen themselves as the Britisher sees them in almost every type of interpretation, ranging all the way from Thackeray and Dickens to H. G. Wells and Arnold Bennett. Yet there is always, even in the most tolerant advice-loving Yankee mind, the suspicion that Americans are Americans by reason of the innate might of a few distinctive principles germane to the nature of things in the United States, and rooted, as one might say, in the subsoil of this Western land-principles which are loath to give their color to a transient stranger.

Still it is with England that our business interests and spiritual ideals are more nearly identical than with any other nation, and it is to England that our admiration and respect have gone forth in a multitude of ways, even when we have been unconscious of it, or perhaps rather too proud to admit it. Since, furthermore, we were all Englishmen in the beginning, we may be justified in turning to a brief 
contrasting study of the two pcoplc as a means of bringing out more clearly certain of the distinctive traits and ideals of the inhabitants of both countries.

It is first needful to remember that the distinctions in the United States are traditionally not of aristocracies, but of merit; not of age and the "sense of elevation" derived from the contemplation of either majesties or monuments (sinee we have none of the former and few of the latter), but primarily the distinctions eentering in men and their work. There is, moreover, comparatively small respect in America for men of good birth but of bad character or unemployed talents. Even the adornments of the artistic comnoisseur, and the idle or "gentleman" class, find hero in this land of plain reality little more than euriosity and that kind of respectful attention given to unusual "specimens." The erowds may line the sidewalks in front of a Fifth Avenue church to watch the wedding proession of a scion of one of the few old families of wealth still left to us; but even a casual study of the faces and a slight analysis of the remarks of the spectators will reveal the abysmal difference between the thoughts called forth by this speetacle on Fifth Avenue and those seemingly uppermost in the minds of the London watehers of nobility on Pall Mall, or at the marriage of the son of a duke or an eminent representative of an old English house.

A chief engineer, on the other hand, returning from his notable labors in eonnection with the building of the Panama Canal, ealls forth a crowd as diverse in character as it is serious and respeetful in attention, and the man of deeds is plaeed upon a pedestal of honor and national regard to which the mere inheritor of wealth or an old family name can never hope to aspire.

Through reasons more or less evident, American ideals gather instinctively about people like Edison, of whom the public never tires of hearing. They like to read how he spends long, sleepless nights working out his latest electrical invention, which they are certain will open new windows into a more usable world. The crowd never tires of read- 
ing or hearing of Lincoln, whom certain European writers have truthfully said was without "distinction" and who was undoubtedly at times ordinary, even perhaps vulgar, both in the speech and manners of his day. But Lincoln visualized that which Americans prize more highly than coronets and Norman blood-heart quality-and the nation's ideals and reverence cling closely about his memory. His homely wit and kindliness appeal to their love of real things, and they keep green his grave with a sentiment as deep as it is disregardful of the lowliness of his early social station and possessions. This is not far from the innate respect felt in the souls of all men everywhere for great humanity, and in this type of elevated regard the dwellers on the North American continent are seeond to no people beneath the sun.

We would not minimize the need, in this country of magic business endeavor and enormous raw material of both heart and hand (material which has not yet had time to be worked into artistic expression), of the erection upon these strong basic traits of a superstructure of gentlemanly manners and a worship of beauty in all its forms. This is a thing which time and leisure and growth may be conducive to strengthening, all to the betterment of American civilization. In such matters the American may look, as indeed in many another thing, to the land which gave England and these United States a common stock.

To come to a more detailed and eoncrete comparison, one is at once struek at the amazing contrast between the Englishman and American in the realm of feeling and expression. The Ameriean is first of all volubly expressive, while the Englishman is studiedly reserved. The Britisher is a kind of negationist; he is almost stoically repressive, and frequently inarticulate. John Galsworthy has said that there is no more deceptive person than the Englishman on the face of the globe, his deception being due to his inability as well as his unwillingness to make himself understood. The American, on the other hand, is enthusi- 
astic, fluent, and is quite ready usually to examine and to expatiate upon his own inner feelings as well as to mako a guess at those of other people. To hide his feclings is second nature to the Englishman. Should his cmotions by some unwary ehanee get the best of him, he is usually ashamed of himself and expeets to be laughed at. He deprecates any lapse from his suppressed idealism. The American feels that some of this is parade, what Robert Louis Stevenson called, "A winking, curled and oiled, ultra-cultural-Oxford-don sort of affectation," and discounts it aceordingly.

A few years ago I was talking with a young man over the omnipresent tea urns at Oxford regarding these matters of English and American traits, when I ventured to suggest that his father (a prominent Englishman) was a fitting example of the Britisher who had accomplished fine work and had not talked much about it. When I began to speak of a book which had pictured this public man with his accomplishments in South Africa, the son swept the matter aside with a deprecating gesture, saying, "Oh, the govcrnor's all right," and turned the conversation to the last cricket match with Cambridge.

At the Oxford Union, that miniature English world, where, in a manner strange to America, the chief members of Parliament return to preside at the sessions, helping to keep inviolate the English traits and the attitude of the English mind toward public service, I have heard students called down severcly for giving a suggestion of emotionalism in their speeches. In fact, one student, who in our American judgment had made by far the best presentation of the evening, was riddled as to his argument and his side utterly routed, because his opponents had credited to him an attempt to play on the feelings of his hearers through an illustration suggestive of "spread eagleism." To the American, accustomed to the public mode of expression in his own land, this show of feeling would have hardly been noticeable, certainly not objeetionable. Another 
student demolished his opponent who had been lured into sentiment by saying:

Sir, Mr. - has tried to wring our hearts. I submit, Sir, that our hearts refuse to be wrung!

The state papers, as well as the public addresses of Englishmen, while on a high level of intellectual reasoning, and exhibiting frequently examples of choice diction, often make dry reading for the man who has become familiar with the American type of political presentation. An American politician has observed that the only parallel to the human interest found in the congressional records filed away upon the dusty shelves in Washington are the "popular" speeches of the members of the House of Commons, reported in full in the dreary columns of the London Times.

A conservative master of one of the old colleges at Cambridge remarked to me that the principal objection he found to Lloyd George (who was at the time, several years before the war, delivering speeches in Wales on the land question) was that he reminded him of his namesake Henry George, whose spellbinding characteristics were as unintelligible as they were distasteful to the educated Englishman. The attitude is reflected in the statement of Francis Gribble concerning Jowett, the old Master of Balliol, a man

full of milk of human kindness, but profoundly conscious that milk makes a mess when it boils over, and firmly resolved to prevent that catastrophe by keeping it in a refrigerator.

The American is easily moved and often he is easily convinced. It may be added that he is quite as readily cooled and as readily unconvinced. His across-the-seas relative is hard to be convinced, but when his conviction is formed he is a veritable bulldog. One of his countrymen said in relation to his attitude regarding the European war that when the Englishman finally sees and seizes a 
thing, he takes it with the whole of his weight, and wastes no breath in telling you he has taken hold.

The Ameriean is friendly and long-suffering. He does not grumble over trifles, and frequently is justly aceused of being indifferent to his rights, while the Englishman is the most inveterate grumbler, especially over little things, to be found extant, and withal the most determined advocate of his common rights, be these rights loeated in Liverpool, Cairo, Calcutta or Hongkong.

As a chanee traveler the Englishman is about as com. panionable as a stone image and equally eommunicative. His impermeability is a wonder of perfectness. A Danish gentleman who had lived most of his life in an English colony told me of his experienee in erossing Russia on the Siberian railroad from Vladivostok to Petrograd, a journey of thirteen days, in the same eompartment with an Englishman. Their eonversation during the entire trip eonsisted in saying "Good-morning" when they arose and handing each other the daily papers, for which each one politely thanked the other with a bow. Had these two men been Amerieans, at the end of the first day there doubtless would have been no subjeet in all the range between polities, piety, and personalities, that would have not have been diseussed with fervor and thoroughness. The second day would have doubtless been more difficult in the matter of eonversation, sinee they would have told everything readily accessible the first day, but for the Ameriean, at least, the first day's eonversation would have paid for the trip, and not to have expressed himself would have made the journey exquisite boredom.

As a tourist, the Ameriean is the very epitome of good nature, geniality, euriosity and agreeableness. He is a first-elass mixer, talks easily, laughs easily, and his bump of inquisitiveness, together with his temerity in unearthing the unearthable, has made him the areh investigator of the world. He goes in where angels fear to tread, and to want to know about anything is synonymous with finding out. When he is well mannered (and it must be remem. 
bered that not all Americans in these days travel in Cook parties) we venture to say, even at the risk of being called prejudieed, no world traveler of any nation makes a more charming and obliging comrade.

In this relative appraisement of the globe-trotting class one must remember the sources from which the different types of English and Americans come. America with its quick results and quick money has foisted into the world of travel thousands of people whose forebears and antecedent opportunities for culture have been far removed from those familiar to the majority of the English sightseers. A manufacturer of machinery, for example, in the Middle West makes an unexpected ten thousand dollars, and he immediately thinks of how he can expend it for his family. An early thought is to send his kindly, goodnatured, domestically inclined wife, with her little troop of pretty daughters, who are striving for something that their home town does not afford, to Europe, or possibly on a trip around the world. They take with them their freshness, their vivacity, their overbounding health and optimism and joy in every new sight, and their training which has been of the sort that teaches them to give full vent to their expressions of wonder or disdain. The English tourists, meanwhile, shrug their aristocratic shoulders and exclaim: "Those Americans!" It is sometimes forgotten that it is only of late years that the people of the same stratum in England have been either capable or desirous of extending their knowledge or of gratifying their curiosity with the scenes of foreign lands. The average middle-class Englishman is content with his home and fireside, and with good safe 5 per cent investments on his money. These are more tangible and satisfaetory assets in his eyes than the investment in culture for his wife and family.

Kindliness and humaneness, the eommon American traits, are responsible also for the way in whieh the sorrows and calamities of the world cut our countrymen to the quiek. His extremist temperament makes the American prodigal and sometimes foolish with his wealth, and he is often as 
impulsive as he is excessive in his philanthropy. Full of nervous sensibility, he wears out much mental and physica] energy by his neighborliness. The Britisher in contrast is seldom excessive and goes to extremes far less frequently. This makes for a certain toughness of nervous fiber that calls in turn for fewer sanitariums in England than in America; this insensibility to the nerve-racking stress and strain of modern competitive existence has eaused the Englishman to be pointed out as a good example of the conservation of energy; it fits him peeuliarly for a war of exhaustion in which the proverbial ability to "muddle through" and take things as they come are rare talents. 'This trait of repression and staying at home in his own feelings, this inaptitude for saerificial interest in others, saves energy for the Englishman; it also loses many opportunities for being human, or so it appears in the American's eyes.

In the matter of ready adjustment and adaptability, the American easily outstrips his brother of English race. Given the same ideals, the Yankee finds many more means with which to aehieve them, since he has fewer binding restrictions upon his working. His lack of idée fixe and frecdom-confining traditions leaves him free to move morc easily on his bearings, and makes it possible to get things done with promptness and often while the Englishman is thinking it over. The American likes taking risks and is a ready apostle of all progressive measures. His eonservatism, however, is inereasingly noticeable along some lines. I was talking recently with the editor of one of the large American magazines who said it was his policy to publish virtually nothing having to do with current interests in any part of the world. This is quite largely an acquired English trait, and conservatism is naturally of slower rootage and growth in a country where newness, change, and advance are attendants of all activities. That a thing is fresh and untried, and heretofore unheard of, is usually an attractive recommendation, when to the more eautious Britisher a new thing is intended to arouse hesitation, if not suspieion. 
A prominent English writer related to me recently an experience which befell him in connection with an old and very reliable publishing house in London. A seemingly attractive book proposition, involving a number of volumes relating to a widely popular subject, was presented and one that was afterward accepted with avidity and much success by an American firm. The Londoner called in a member of his company to consider with him the scheme. The method of consideration consisted of looking over a dusty pile of records to discover whether the house had ever engaged in a similar publishing venture; finding that it had not, the head of the establishment immediately and without further deliberation as to the particular merits or demerits of the plan before him, rejected the proposal, saying with a thoroughly satisfied and conclusive air: "No, we cannot accept it; we have never undertaken anything like that." Tradition ruled, and contemporary interest lost.

A New York publisher was next approached, and his first question, according to the narrator, was, "Is there any similar set of books in existence?" When he had made sure that the idea was a new one and after he had consulted with his "men on the road" to find out whether they thought it would appeal to the latest tendency in current demands, he said:

This looks good to us. We will take it. We believe it will make a hit from the start, since it is a new angle of approach.

And it did, though in England it night have been a dismal failure, and have justified fully the hesitation of the London publisher. It reveals the ever ready willingness of the American to take a chance on a new thing. This same unreadiness to change from the English manner of doing business has been the reason for more than one British failure in the Far East, as the converse trait of fitting the product to the customer and the latest requirement of the public has spelled success especially for the German in that region. 
It is probably au fond the ideal of getting on, the aim of success through adaptation, that is felt in this drift away from any final or accepted way of doing things. The middle-class Englishman, constitutionally solid and stolid, is satisfied and quite resigned to his fate of middle-class existence, taking it as a matter of course, and therefore devoting himself to the immediate duties before him. No large dreams or future ambitions blur his eyes. The American, on the contrary, is never content and is always seeing himself rising out of present mediocrity to leadership and power in the class of business men or stratum of socicty immediately above him. The Englishman, moreover, is inclined to take his business as a necessary evil, especially the Englishman of the upper classes: a thing to be gotten over as quickly as possible, so that he may get on to something else: golf, shooting, or polities, for which he eares infinitely more than for his office work. The American regards his business as his main activity in life; it forms often his diversion as well as his daily task; "he is all busimess"' is an expression frequently heard. It is the one thing for which he delays his pleasures and recreations and amusements and travel, it is the altar upon which he too often immolates matters of intellectual and cultural interests; it is a veritable religion to many, and no man of any other nation, not even the shopkeeping Chinese, worships more loyally or unintermittingly the eapitivating gods of trade.

It is beeause of his devotion to business that the European newspaper artists never weary of picturing Uncle Sam as a pork packer millionaire and the shrewd Yankee trader with the head of a hog and the octopus body of a trust magnate. We have yet to find a eompany of foreigners either abroad or at home who fail, after a few moves of the conversation, to bring up the money wraith against the American. Without doubt we have here a subject of striking interest close to the nation's idealism and fruitful of marked comparison with English aims. That the American thinks in terms of money, and that wealth bulks large in 
his estimate of success, no one closely acquainted with him will deny, but when it cames to a comparison in the matter of the reason for acquiring dollars, we doubt whether he will be found more materialistic than the Englishman.

Certain it is that in conversation the Englishman has been reared to talk of other things than his income. He has been trained to connect the commercial transaction with a lower order of society and accomplishments than those represented by the persons and activities connected with public life, the realm of letters, and especially the careers of his military and colonizing countrymen on the seas or in distant climes.

When one turns to the mental consciousness of the two peoples, and this consciousness is closely akin to the spring of their idealism, one finds sharply outlined a few distinguishing features. In the United States it is easier to find persons who are self-conscious and imaginative, and who include the past and the future as well as the present in their introspective sense of themselves. Many an American is a dreamer, and as much of a failure in a practical way as is the speculative Easterner. There is a marked sensitiveness when it comes to the fear of public opinion in regard to his fellows, while the prevalence and the flourishing success of almost every kind of metaphysical or religious sect known on the face of the earth is a mark of his unqualified mental receptiveness.

The Englishman, on the contrary, however much he may scout the idea of materiality in his patronizing attitude at times toward his New World cousin, dwells in the realm of facts, and often in the atmosphere of a blind practicality, even more than does the American. As a business man, the Englishman is "awfully level headed" and gives the impression to many foreigners of a distressing matter-offactness. His religion he accepts as he accepts his national consciousness, as a matter of course, and one finds abstract discussions of religion and philosophy as infrequent and usually distasteful interlopers in the ordinary English conversation. New religions and anything that approximates 
to fads and fancies are not readily received in that land of conservatism.

To the adaptable and ideal-loving American the popular sentiment welcomes change so rapidly that in some respects it is open to the Frenchman's retort regarding his own people:

I put no faith in any of the laws of literary history, except in that which consists in saying that a fashion succeeding another fails if it is not the absolute converse of that which preceded it.

The solidity and imperturbability of the Englishman in contrast is often as unintelligible as it is foreign to the American temperament.

It must be remembered, especially as far as the leadership of English thought and action is concerned, that the twenty or more large English public schools, which have no counterpart on earth, and which train at least one hundred thousand of English youth of each generation, are responsible largely for this uniformity of mentality and this mysteriously cool, critical, and reserved manner. When one appreciates that seven-eighths of the important positions, public, professional, administrative, as well as an increasingly large number of notable posts in England's present day industrial enterprises, are held by the graduates of schools of which Eton, Harrow and Rugby have been for generations the exacting models, there is found at least one reason for the English mind. Here young England learns impartial justice, and acquires the knowledge of how to gover'n others as wcll as himself. Here the orderliness and obedience to law, so much needed in the United States just now, becomes second nature to the young Britisher. These schools cultivate the negation of self-consciousness, and are more or less inimical to that type of individualism which the multitudinous vocational schools of America, with their emphasis upon individual aptitude, magnify and develop. 
The negative philosophy of these schools of England, whose spirit enters so largely into the English ideal, has been humorously satirized in a code of tell commandments of the English schoolboy, by a French writer in the Revue Politique et Parliamentaire.

1. There is only one God, and the Captain of football is his Prophet.

2. My school is the best school in the world.

3. Without big muscles, strong will, and proper collars, thero is no salvation.

4. I must wash much, and in accordance with tradition.

5. I must speak the truth even to a master, if he believes everything I tell him.

6. I must play games with all my heart, with all my soui, and with all my strength.

7. To work outside class hours is indecent.

8. Enthusiasm, except for games, is in bad taste.

9. I must look up to the older fellows, and pour contempt on newcomers.

10. I must show no emotion, and not kiss my mother in public.

In these training places of English schoolboys there is as little attention given to bothering about one's inner state of consciousness as one can imagine. One teacher told me that he did not want his boys to bother about their souls, but to take care of thcir bodies and their souls would take care of themselves. As a consequence you will rarely seo a high degree of moral or mental sensitiveness on the part of these graduates. They do not brood, neither do they take undue trouble about their future state. Neither do they sit up nights to do original thinking relative to their philosophy of life. They simply accept the traditional forms and go steadily along in the paths their fathers trod.

But in spite of the fact that the methods of training are so strikingly different, the English method fits the English mind, and these schools have furnished a marvelous dynamo for forging and molding Englishmen.

As far as mentality is coneerned, and idealism in the 
realm of intellectual imagination, where idealism is particularly regnant, the American holds his own with the Englishman. Prof. Gilbert Murray of Oxford, after teaching American college boys at Amherst for a year, in answer to my question regarding the difference he noticed among the students of American and English schools, replied: "The American boy is more alert, usually I think moro intellectual; he adapts his knowledge much more readily to the contemporary conditions with which he is closely allied. He lacks, however, the background of knowledge, and especially the knowledge of the classies common among the students of England. He also lacks in a certain reserve, which is one of the notable products of the English public schools."

In a peculiar sense this college and schoolboy life of the two nations reflects the countries of which they are a part. The Englishman, repressive, matter of fact, slow to action but tenacious to the end, drawing his inspirations from staid and sacred traditions of a great past, takes his whole life more practically and with a self-confidence that often refuses to admit that idealism has part or lot in his thinking. The American, on the other hand, who draws his sentiment and ideals from the shining glory of the present, is not ashamed either of his dreams or his optimism. He has already seen so many evidences of his constructive imagination that he is willing to believe the strangest miracles of his mind. By the very expression of his enthusiasm he grows more and more convinced of the possibilities both of his head and of his heart. As the years roll, he will become increasingly conservative, and the mannerisms of a new world state will be tempered by the gentler arts to which his hand is already becoming accustomed. That he will ever become English either in the spirit or the revelation of his ideals, is not to be expected, for the breath which he draws is filled with a different ozone, for him surely a more rarefied and exhilarating air. As the ground beneath his feet stretches away to a continent whose borders only have been touched into life by 


\section{FOREIGN TRADE MARKETS AND METHODS}

the magic of his hand, as he beholds as now new worlds abroad in which to expend his genius for industrialism, likewise his idealism will grow, and his visions will expand until they are wide enough to match his boundless dreaming and deep enough to satisfy his restless soul. 


\section{CHAPTER XXVI}

\section{TRADE WITH THE NEW EUROPE}

More than ever since the European war and the growing financial relationship of the United States with Europe, there have been eoming about new trade relationships and the bases are being laid for routes of commerce heretofore unknown between the United States and Europe. Apart from the serious obligation of this country relative to the rehabilitation of the European fighting areas, American manufacturers and business men have appreciated the necessity of investments and farsighted business plans relating to Europe which are bound to associate American and European markets in a closer and more vital way in the future than has been the case in the past.

We give some of the outstanding features of these markets which merit very close and exhaustive study by students of trade and manufacturers espccially in times when trade routes are changing and developments in shipping and foreign markets need to be watched with constant and continuous care.

Central Europe.-A study of the growing trade with the political division of Europe resulting from the war, including Central European countries-Russia, Germany, Austria-Hungary and Turkey, reveals interesting features. It is significant that in the year 1920 American business with this area, measured in dollars, was greater than in the year preceding the war.

To Germany representing four-fifths of the former area of the German Empire, with approximately five-sixtlhs of its former population, the United States exported in 1920, commodities valued at about 90 per eent of those sent to Germany in 1913. The imports from the new German 
Republic during 1920 were valued only at about 50 per cent of those from the German Empire in 1913, the total official valuation of the United States' trade with Germany in 1920 being in round figures $\$ 400,000,000$ as against $\$ 536$,000,000 in the year 1913.

American trade with Austria-Hungary in 1913 amounted to about $\$ 42,000,000$, and trade with the new Austria in 1920 was valued at $\$ 21,000,000$, chiefly in foodstuffs for the immediate needs of the Austrian people.

With the Czecho-Slovakia area which was formerly a part of Austria-Hungary, the United States carried on a trade of about $\$ 17,000,000$, about equally divided between imports and exports. Add to this the enlarged trade with Jugo-Slavia and Greater Rumania, and American trade with this section is revealed to have been much larger in 1920 than in the year 1913.

The Baltic trade, furthermore, shows even a greater increase; especially with Finland, Esthonia, Latvia, Lithuania and Poland. With Finland the total in 1920 was $\$ 24,000,000$ against less than $\$ 4,000,000$ in 1913 , and with the new Poland about $\$ 70,000,000$ chiefly exports to that country. The records of each of the Baltic States show a substantial interchange with the United States due to the presence at their ports of numbers of American firms.

On the Mediterranean coast the trade of the United States in 1920 was many times that of 1913 . With the greatly enlarged Greace it aggregated $\$ 60,000,000$ in 1920 , against less than $\$ 5,000,000$ in 1913 . With Greater Rumania it was two and a half times as much as in 1913, and with Bulgaria 15 times as much. With Turkey it amounted to $\$ 80,000,000$, against $\$ 25,000,000$ in 1913 .

To summarize, in the entire world area in which the war resulted in new governmental organizations or marked readjustments of boundary lines, the trade of the United States in 1920 was approximately $\$ 900,000,000$, against about $\$ 685,000,000$ in the year before the war.

Belgium.-In the year before the war the United States 
exported to Belgium upwards of $\$ 67,000,000$ worth of goods, while the imports from that country were approximately $\$ 100,000,000$. In 1919 , however, the total amount of exports were nearly $\$ 323,000,000$, while imports amounted to $\$ 647,860,000$.

The high industrial development of Belgium, and her large manufacturing industries have made this country an important factor in foreign markets, while her rapid revival since the war has revealed her inherent possibilities for botit home and foreign commereial incustry. Her industrial products have been in iron and steel, the construetion of steam and gas engines, automobiles and machinery of all kinds, together with the production of zine, glass and chemicals, and a very important textile industry. Belgium's coal mining is of great importance, while there is extensive agrienlture, eattle breeding, dairy farming and the growing of fruit, flowers and vegetables.

The United States supplied 8 per cent of the totai imports of Belgium in the year 1912. Belgium's largest commeree was with France and Germany previous to the war.

France.-The Republic of France carried on a total foreign trade with the United States in the year 1913 of approximately $\$ 146,000,000$ in exports and $\$ 137,000,000$ in imports; in the year 1919 these two figures had grown respectively to $\$ 976,000,000$ in exports and $\$ 62,000,000$ in imports.

Before the war 20 per cent of the population were engaged in agrieulture as compared with 23 per cent in Germany and 5 per cent in Great Britain. Vineyards, silk culture and the cultivation of corn, wheat, millet and beets are among the important agricultural activities.

There are highly developed manufacturing industries, the chief being in the line of clothing and adormment, textiles, foodstuffs, ehemicals, machinery, perfumes, jewelry and novelties. Approximately 13 per cent of the population of France were employed in manufacturing industries before the war as compared with 25 per cent in Great Britain and, 17 per cent in Germany. 
The acquiring by France through the war of the Saar Valley coal mines adds 17,100,000 tons of coal anrual output, while the return of Alsace-Lorraine adds to her normal iron output over 23,000,000 tons.

of the different nations the United States and the United Kingdom are the chief markets for France, her total imports from the United States alone ranging between $\$ 1,000,000$,000 and $\$ 2,000,000,000$ in the years since the war, and aggregating somewhat larger than French imports from the United Kingdom.

The large, new investment interests of the United States in France assure an ever increasing trade between the two countries, while the sympathetic entente between the two nations make for cordial relationships both political and commercial in the years to come.

Italy.-Together with France and Belgium Italy is revealing increasing signs of encouraging industrial progress since the war particularly in her prineipal industries of agriculture, mining and manufacturing. As in France, wine making is an important industry, together with the cultivation of olives, almonds and citrus fruits. Silk production is carried on by cultivation of the mulberry tree, while in manufacturing industries, machinery and the making of steel are of importance, as well as chemical industries and the manufacture of foodstuffs.

The result of the war has given Italy extended territory to the North, where she acquired possession from Austria of the Trentino, and she has also extended her territory on the Adriatic coast through the occupation of the former Austrian province of Trieste. This province has an area of 3078 square miles and a population of 893,797 . The control of this district assures Italy of Trieste, an important port with a population of about 247,000 .

In addition to this newly acquired territory Italy claims the Dalmatian coast of the Adriatic which includes the port of Fiume. These claims, however, are disputed by the new State of Jugo-Slavia.

The total foreign trade of the United States with Italy 
in the year 1913 before the war was in exports approximately $\$ 76,000,000$ and imports, $\$ 54,000,000$, while in the year 1919 , these exports had grown to approximately $\$ 496$,000,000 and the imports had decreased to somewhat more than $\$ 21,000,000$.

Italy's prineipal articles of import from the United States for the three years since the war have been in such commodities as cotton, wool, horsehair, minerals, metals, manufactures, cereals and regetable products, medicinal substances, gums, perfumery, spirits, beverages and oils, together with pottery and glass.

As with France, the United States is one of Italy's largest foreign business clients.

Spain.-Among Spain's chief products are wine and olive oil. In a recent year Spain manufactured approximately $600,000,000$ gallons of both red and white wine and the value of these exports comprise something like oneseventh of Spain's total exports. The olive tree is one of the most important in Spain and Cordova is the headquarters of the olive oil industry, while Scville is the center of olive eultivation for table use.

Since the war the textile industries of Spain have becomo more important, comprising upwards of 8,000 establishments for manufacturing cotton, woolens, silks, hemp, dyeing, bleaching and associate industries.

The enlarged use of electrieity in reecnt years has greatly added to Spain's industrial progress, there being $\$ 300$,000,000 of capital invested in hydro-electric enterprises in this corntry.

Spain's minerals include iron, copper, lead, manganese, quicksilver, silver, sulphur and phosphorus; her metallurgical industries are increasing.

Her total foreign commerce since the war has decreased approximately $\$ 300,000,000$ about evenly divided between exports and imports, a decrease from pre-war commerce, though in the year 1919 the balance of trade was in Spain's favor.

In the year 1913 the United States stood fourth in the 
aggregate of both imports and exports with Spain, her largest commerce being with Great Britain, France and Germany, with a considerable trade with Argentina.

Portugal._Portugal's principal industries are agriculture, fruit-raising and mining. As in Spain there are large olive groves and the manufacture of olive oil is an important industry. The wine industry centering in Oporto is a very large one, while the most important mineral product is copper which is mined in the southerm portion of the country. Fishing is also important as well as the mining of tin, iron and lead. There are textile factories and canning factories among the manufacturing industries, while metallurgical plants are being developed.

The total foreign trade of Portugal before the war in the year 1913 was somewhat above $\$ 144,000,000$, and the value of the total trade of the United States with Portugal in 1919 was about $\$ 4,000,000$ exports, and $\$ 7,000,000$ imports.

Further details relative to trade and specified markets with European countries may be secured by examining the latest Commerce Reports issued by the Bureau of Foreign and Domestic Commerce, or by writing this Bureau for special reports on various countries where trade information is desired.

While special emphasis is given in any treatise having to do with foreign trade, to the opening of comparatively new markets in countries undergoing present-day commercial and industrial development, the merchant, manufacturer and trader need always to keep in mind the older markets of Europe which have always played so large a part in the overseas trade of the United States. 


\section{CHAPTER XXVII}

\section{CARIBBEAN MARKETS}

If proximity counts, as it most eertainly does in commerce, the markets of the countries, our neighbors to the South, fringing the Caribbean Sea, should be of primal interest to North American traders.

The West Indies have been called "the scattered fragments of a broken continent, situated in an extensive excavation apparently seooped out by the hand of Providence." These fortunate isles, together with the northern portions of South America, Panama, the Central American Republies, Mexico and Cuba enclose a sea which in the annals of future trade, is quite likely to rival for commeree the history of the Mediterranean.

In this circle must be included Mexico, our nearest neighbor, which country has 327 miles of her coast lying on the Caribbean, and with her possible resources hardly yet discovered after centuries of political and racial vicissitudes. No one can appreciate this country until he has read at some length of those early days of the Aztees who fought with the Spanish conquerors for supremacy on the lofty Mexican tablelands, or drove one another alternately down to the tropic coasts of the Caribbean. The story of the intrepid Cortes, as told by Prescott in his Conquest of Mexico, has few superiors in interest, either in the realm of history or romance. To know what history lies behind the modern Mexican, whose trade we desire, is first of all essential.

The turbulence which has been associated with Mexican affairs of late years has concealed from us at times the fact that we are the northern neighbor of one of the most 391 
potential areas, as far as resources and commerce are concerned, in the world. Here is a vast country with an area of 767,097 square miles, with 45,074 miles of coast line on the Pacific Ocean and 1,400 miles on the Gulf of Mexico, in addition to the 327 miles already referred to skirting the Caribbean Sea; with a population of upwards of $15,000,000$, for the most part uneducated Indians, business largely in the hands of foreigners, with 16,000 miles of railway and 34 deep water ports, Mexico is still waiting for sufficient political stability to utilize her natural wealth.

This wealth exists in mines of silver, copper, gold, lead, antimony and zinc. The country is rich in petroleum, in agricultural products, while her vast domains furnish exceptional opportunities for cattle-raising. The mountainous character of the country and Mexico's numerous streams afford rich advantages for water power.

At least $\$ 500,000,000$ of American money have been invested in Mexico in mining-probably more than has been spent by all other nations combined. Among her agricultural products for exchange are cotton and rubber, corn, eacao, coffee, heniquen and tobacco. In the year 1913, previous to the European war, silver amounting to $\$ 44,500,000$ was Mexico's principal export.

The present-day conditions give many of those who know Mexico well a confidence to believe that this country, so long torn by strife, is now about ready to begin a con. structive and permanent upbuilding and that the United States, naturally, should be in the future Mexico's greatest customer as well as her leading market. This depends quite largely upon the manner in which we may become at this vitally important moment in Mexico's destiny, her friend and commercial aid.

We look far over the seas, spending money without stint for markets and also for raw materials for our manufactures. In this world-wide search for trade, it is well for Americans to remember Mexico-our next-door neighbor.

Cuba.-Ninety miles south from Key West, lying in the line of one of the great trade routes of the world, is Cuba, 
an island from 20 to 100 miles in breadth and 730 miles long, with an area somewhat larger than the State of Pennsylvania. Its landlocked harbors, its $13,000,000$ aeres of forest, its superlatively rich tropical vegetation and resources, together with its delightful climate, make a possible habitation for certainly three times its present two millions of population. Its sugar, its tobacco, its fruit, its latent agricultural, mimeral and industrial wealth, are worthy of particular notice by North Americans. Tho following table gives an idea of American exports to Cuba and the relation between these exports sent to other of the West Indian Islands:

\begin{tabular}{|c|c|c|}
\hline & 1915 & 1918 \\
\hline 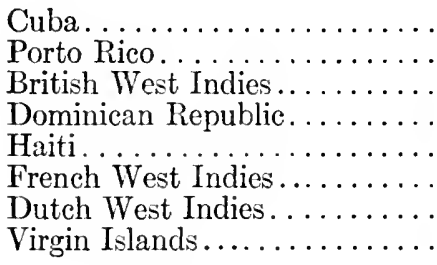 & $\begin{array}{r}\$ 95,750,004 \\
44,318,151 \\
13,948, \$ 20 \\
7,447,182 \\
4,899,856 \\
2,698,050 \\
1,269, \$ 08 \\
882,442\end{array}$ & $\begin{array}{r}\$ 227,156,047 \\
54,043,349 \\
21,432,437 \\
16,156,443 \\
9,069,275 \\
5,357,451 \\
1,361,434 \\
1,640,130\end{array}$ \\
\hline Total. & $\$ 170,914,333$ & $\$ 336,216,539$ \\
\hline
\end{tabular}

The total for 1918 represents an increase of 97 per cent over that of 1915 .

Cuba is particularly of interest to American trade beeause of the happy political relations which have existed since the Spanish American war and the enlarged development of Cuba will naturally mean an enlarged trade between this Island Republic and the United States.

Cuba is called "a prospective four million ton sugar eane proposition." In 1919 it had already approximated 4,000,000 tons. The sugar crop exceeds in value ten-fold tho tobacco crop and Cuba's total commeree has reached $\$ 700$,000,000 annually, the United States possessing a major part of this trade, taking about 85 per cent of Cuba's 
exports and supplying the Island with about 60 per cent of her import requirements. Cuba is a constant market for foodstuffs, machinery, tools, hardware, chemicals, textiles, shoes and drugs.

Cuba has been called "the world's sugar bowl." Steampower machinery driving out the old picturesque windmills, with the vacuum pan conserving that which formerly went to waste in the processes of evaporation, have come to the help of sugar production in this rich island.

To British India and to the Caribbean section the world looks to-day for its chief cane sugar producing areas. British India in 1914-1915 produced 2,400,000 tons of sugar, while the Caribbean output was $3,243,000$ tons. Of this latter Cuba produced 2,600,000 tons. This amount has increased vastly each year since 1914-1915.

As far as international trade in sugar is concerned the Caribbean region far outranks all other markets since British India, one of the oldest sugar producing countries, consumes its own production and in addition imports ammually about $\$ 25,000,000$ worth of sugar. Comparatively little of the West Indies production is not transported.

The United States trade in sugar is revealed by the fact that Cuba in a recent year furnished to this country $4,785,000,000$ pounds of sugar, the total consumption of sugar for that year (1914-1915) being $8,630,000,000$ pounds.

American producers as well as the owners of sugar industries in Cuba are increasingly important. In 1912 and 1913 a Britisher Consular Report stated:

A very large proportion of the mills (in Cuba) are in the hands of Americans, and it is probable that not more than onethird of the mills remain in Cuban hands.

Among the other resourceful sections of the West Indies, important for American markets, are Porto Rico and the Virgin Islands belonging to the United States, while the Islands of Haiti and San Domingo are closely related both 
by political control and commerce to this country. Porto Rico counts sugar among its chief exports, sugar making up nearly half of its exports in valuc, although tobacco, coffee and tropical fruits are important. The Island imports foodstuffs, machinery of all kinds, cotton goods and shoes. United States money is used and there is an excellent shipping service.

Haiti's chief exports are coffee, cocoa, dyewoods and medicinal gums and her imports are similar to those of Porto Rico.

San Domingo produces Caribbean products such as sugar cance, cocoa, tobacco, coffec and also raises bananas; she also exports dyewoods and hides. Her imports consist of cotton, cotton goods, iron, steel and foodstuffs which are largely (at least 70 per cent) from the United States, while she sends 50 per cent of her exports to this country.

The Central American States consist of five Republies and British Honduras and Panama add practically the same kind of produets to the Caribbean markets, with a very much increased trade in bananas. In this industry Costa Rica leads, while Guatemala's chief export is coffee. Other exports are tobaceo, indigo, rice, sugar, cocoa and cocoanuts, the bulk of the business in these Republics being in United States hands, many Americans living in these sections. Our chief competitors are England, Germany and France.

Imports to these Republies include practically everything in manufactured supplics such as cottons, woolens, iron and steel supplies, food products, and agricultural products, electrical supplies and hardware.

The trade in tropical fruit in the Caribbean section promises to be an increasing business, while the tobacco industry in Cuba, as well as the oil resources, may be studied with profit by American capitalists and commercial developers.

The Land of the Banana.-It is in the banana industry especially in which Americans have had a very large share in these Caribbcan markets and a brief study of this 
industry in relation to the character of the population and the possibility of American enterprise makes a fascinating chapter in foreign commerce in Central American markets.

To most of us the banana is usually eonnected in some far away and mysterious manner with the tropies. We recall with certain vividness a pieture seen in our youth of a solemn-looking missionary with open Bible standing beneath the protecting leaves of a banana tree, preaching to a small band of naked savages clustered about him. The thought of the banana, if we think of it at all, brings to the imagination visions of indolent natives clad in abbreviated clothing, wandering in luxuriantly luung banana groves, where without effort or exertion on their own part, they have only to pull down the golden fruit with which generous tropical nature has provided them.

But these are schoolbook visions and pretty delusions, sinee we all know if we have studied the banana industry at all, that tropical jungles are foodless wastes and that there are no wild bananas fit to eat. We also discover soon that those dauntless pioneers who through a series of vicissitudes that would have daunted the average man have made it possible to bring into the United States yearly more than 40,000,000 bunches of bananas, ereating a commerce amounting to more than $\$ 105,000,000$, have at the same time ereated an enterprise which deserves to rank with the greatest achievements of the last twenty-five years.

It is only when some attempted legislation by shortsighted lawmakers has brought this matter to the attention of the multitude that we have given any considerable attention to the growing reign of the banana amongst us. When some years ago a bill to tax this tropieal fruit with a tariff of five cents a bunch was presented to Congress, the press of the nation voiced the convietion of the masses, and with one united protest squashed this attack upon a product which had come to be a settled fact in the lives of millions. John O'Keefe in the New York World delivered his message in verse regarding this matter: 
We are anxious that beef should be cheaper,

So we'll lower the tariff on cow;

Though it comes from the Plate or the Dnieper,

We will lessen its price to the frau;

And the wheat of the Muscovite reaper

May sustain the American man;

But far greater than these

Is the joy that he sees

As he lives on the handy banan'!

As we write these words in the midst of a great banana plantation in Central America, as far as the eye can penetrate the waving fronds of these tropical trees can be seen, and the ship that brought us here will carry back to New York 80,000 bunches of this golden fruit. During a recent year the United Fruit Company shipped to the United States 24,975,640 bunches of bananas. Counting a standard bunch as containing 144 individual bananas, a little arithmetic will show you that this company, organized in 1899, is instrumental in bringing to the United States yearly more than $3,000,000,000$ bananas, for whose cultivation and production the company employs more than 60,000 men, a large fleet of ships, and places behind the project assets of over $\$ 80,000,000$.

In these days when we are turning our eyes to the possibilities of industrial and commercial accomplishment in lands other than our own, the conquest of the tropies in behalf of the banana enterprise by American business men is a story of inspiration and enchantment.

It is a saying frequently heard in the tropics, that "nature knows how to grow bananas, but man had to learn how to ripen them." The history of how this lesson was learned cannot be more vividly revealed than in the example of the United Fruit Company, which now stands in the forefront of the banana industry of the world-a company which is said to have put Central America on the commercial map. That small band of New England merchants who dared to venture on uncharted commercial seas about twenty years ago with a small initial investment of only 
$\$ 20,000$, took as their ideal, "Small profits on big sales." They systematized the banana industry which up to that time had been only a business specialty. They conceived the idea of buying the land upon which to raise their products. They departed from the generally accepted rule of concentrating commercial energies and insured their interests against the inevitable climatic disturbances of tropical regions by seattering their endeavors and possessions over Cuba, Jamaica and Central America. They made plans at an early datc in the progress of the enterprise to raise their own live stock for transportation purposes and for the subsistence of their workmen, and they now own more than 30,000 head of live stock, valued at more than $\$ 1,000,000$.

These far-sighted business projectors of trade saw also the necessity of building railroads and tramways and constructing ships suitable for carrying the most perishable of products to northerm ports. The result of this foresight is 30,000 miles of railways and tramways owned or operated by this company, adding to the firm's assets more than $\$ 10,000,000$, together with a great fleet of ships aggregating a tonnage of more than 400,000 tons and valued at upwards of $\$ 15,000,000$.

Not the least advantage of this enterprise, organized particularly for the fruit trade, exists in the so-called "great white fleet," which aecommodates more than 3000 passengers and has introduced so many hundreds of Americans within three brief sailing days to the tropies.

The problems connected with the banana industry are many and various, but the labor question is one always to be reckoned with. Modern production of this fruit is carried forward on such a large scale that it has necessitated the importation of workmen. The Panama division of this company employs 7000 men and these are scattered over plantations embracing more than 170 square miles of land. The majority of these laborers one finds in the banana groves of Central America are negroes from Jamaiea or other islands of the West Indies. Although the wages paid 
by the large banana companies are far larger than has ever before been offered in this part of the world, practically as high as those given in the United States, it is well nigh impossible to tempt the average Central American native to work. Moreover many of them seem to be incapable of sustained manual labor.

Generally speaking, there are three classes of people in Central America: the aristocracy, composed of the educated, land-owning and official class, who, as a rule, decline to interest themselves in business or in modern agriculture; a small middle class which contains the men of salaried occupations and professions; and Indians composing numberless tribes and following many customs excepting the habits of physical labor, for which they seem to hold an inveterate repugnance. Whether it is because he lives in a country where the conditions of soil and climate remove much of the incentive and necessity to work, or whether, like some of his white brethren farther north, the Indian was born lazy, are questions for the ethnologist. The American, German or British business man, however, accepts these conditions and calls the West Indian Negroes by the tens of thousands to the various modern industries of Central and South America.

No one should forget that the huge task of developing the neglected wilds of Central and South America is largely the task of the negro as far as manual labor is concerned, and in no part of the world has the black man proved more surely his raison d'être.

After the visitor from the North has ridden for a hundred miles through such Central American banana sections as are found in the Changuinola and Sixaola districts lying along the Caribbean coasts, and has beheld the 250 miles of carefully constructed railway, linking an area of 109,000 cultivated acres of bananas belonging to the United Fruit Company, where the largest and choicest bananas to be found anywhere in the world are raised, he will begin to realize that there are some Americans at least who have heard the call of the tropics as a challenge for industrial 
enterprise. He will gain a new respect for his own countrymen as well as learn to be chary about loose talk concerning the worthlessness of the negro race. It is the happy combination of northern capital and intelligent organization with the physical labor of the negro, who has found his natural habitat beneath southern skies, that is now creating the new wealth of these republies and reclaiming for the people of all lands the beneficent uses of the tropical wilderness.

That this vast banana industry, finding its home in the beautiful island of Jamaica and along the coasts of the Contral American republies especially, has made an enormous contribution to the food welfare of the nations, cannot be denied.

One of the cheapest food products, which in the fluctuating periods of high and low food prices has maintained essentially the same low and even cost, one of the most difficult products to grow and to ship because of the reasons we have narrated, and by reason of the perishable character of the banana, this is now offered for sale in the United States and abroad at all times in the year for less than the average prices charged for hardy native fruits grown only a few miles from our city markets. This feat has been accomplished by the outlay of fortunes, and in fair competition between scores of banana companies operating in these tropics.

The situation and the work of the banana companies which have been spending money and men so freely for the last twenty years have been summarized, thus, by an editorial in the Houston Post:

How does it happen that the home grown apple is placed beyond the reach of the average consumer and that the foreign grown bananas increased in quality and decreased in price? The banana is a perishable fruit. It must be marketed immediately on its importation, and the business is one which requires millions in investment and the risks incident to fleets sailing in waters menaced by hurricanes and northers. It is a farce when apples grown within 10 miles of St. Louis or New York sell by weight 
for 10 times the price charged for bananas shipped from Costa Rica or Colombia, South America.

There is no secret about the low cost of bananas. They are produced and handled on an enormous scale by companies which put them on the market without the intervention of middlemen who extort large commissions. These companies have learned that there is more money for them in selling a huge total of product at a low net profit than there is in extracting a high profit from small sales at prices prohibitive to the average consumer. When those in the apple business learn the lesson there will be more orchards, less apples rotting on the ground and more prosperity and happiness for all concerned. Consider the banana!

Bananas, like sugar, the other cheap and more or less uniform product as regards price, are being produced and marketed in line with scientific and comprehensive systems, thus avoiding the waste and losses consequent upon petty and badly managed production. No one can study this rast husiness in the region of the American tropies without coming to the conclusion that the achievements of Americans in this remarkable field of trade may be duplicated in both kind and degree in many another line, given the same persistent spirit and daring that have actuated the leadership of such concerns as the United Fruit Company and their able competitors in one of the most difficult fields of industrial production. 


\section{CHAPTER XXVIII}

\section{WINNING SOUTH AMERICAN TRADE}

The material resources of South America are in some important respects complementary to our own; that continent is weakest where North Ameriea is strongest as a field for manufacturers; it has comparatively little coal and iron. In many respects the people of the two continents are complementary to each other; the South American is polite, refined, cultivated, fond of literature and of expression and of the graces and charms of life, while the North American is strenuons, intense, utilitarian. Where wo accumulate, they spend. While we have less of the cheerful philosophy which finds sources of happiness in the existing conditions of life, they have less of the inventive faculty which strives continually to inerease the productive power of man and lower the cost of manufacture. The chief merits of the peoples of the two continents are different; their chief defects are different. Mutual intercourse and knowledge cannot fail greatly to benefit both. Each can learn from the other; each ean teach much to the other; 'and each ean contribute greatly to the development and prosperity "of the other. A large part of their products find no domestic competition here; a large part of our products will find no -domestic competition there. The typical conditions exist for that kind of trade which is profitable, honorable, and beneficial to both parties.-Elihu Root.

The word "winning" is used with premeditation in the sense of a race to be won, a race in which our competitors are trained for the contest as we in the United States are not.

South American trade will not be acquired merely by - wishing for it, nor by writing pleasant compliments about Latin Americans, nor by patronizing South Americans, nor by a sudden dash of advertising, nor by starting busi- 
ness agencies. All of these things have their place, but it must be remembered that the gaining of the greatest neutral market in the world is to represent a contest, and that this pearl of great price commereially-the markets of a richly developing continent-is to be won by serious and intelligent effort, by most thoughtful and statesmanlike organization, and by rendering the most effieicnt service of which our best American brains and skill are capable.

Despite the fact of the world-wide business depression occurring in the latter part of 1920 and during the year 1921, attended by world-wide deflation and the disorganization of money exchange, foundations have been slowly but truly laid for a rehabilitated foreign trade with Latin America.

The new trade with South America consequent upon the European war developing our investments at home in new productive enterprises to the extent variously estimated between $\$ 6,000,000,000$ and $\$ 9,000,000,000$ has turned the eyes of our manufacturers and traders particularly to the needs and opportunities of Latin Ameriean markets. The Government has assisted this new trade by new Federal statutes such as the Webb Law, the Edge Act, and eertain shipping legislation intended to assist materially in aiding American commeree to compete successfully with European trade in South America.

The Webb Law has made possible combinations of capital prohibited under the provisions of the anti-trust Iaws, making it possible for various manufacturing interests in the same or similar lines to eombine as a unit for foreign commerce rather than maintaining extensive separate organizations. Already American companies have taken advantage of this Act. The subsidized foreign trade interests of Great Britain and Germany and such arrangements as those fumished by the Cartels of Germany, existing previous to the war, may be successfully matched.

The services furnished by the Webb Law to commerce have a duplicate in the Edge Act and its advantages to banking. The organization of international banks with the 
power to negotiate long term eredits and the endorsement of notes and bills in connection with foreign commerce transactions, together with the right to purchase American exporters' foreign bills, notes and obligations, issuing against these their own acceptances, notes and debentures, is a real step forward in fundamental foreign trade building. There would seem to be a possibility here of meeting the necessity for long term credits demanded by South American houses, since the Edge Act makes possible the extension not only of credit but the loan of capital for the assistance of foreign trade.

The organization, furthermore, of such bodies as the Foreign Trade Financing Corporation, together with the more thorough and systematic construction of chambers of commerce between North American and Latin American countries have been a step in advance, making ready for new progress. The present administration has revealed its sympathetic eoöperation with Latin American trade and with Latin Americans generally by its passage of the Colombian Treaty and by frequent sympathetic utterances by President Harding who has voiced the general trend of feeling throughout the United States regarding an enlarged commerce with our Southern neighbors.

The Panama Canal is another vital asset to trade with South America and is destined to reveal a possibility for usefulness beyond anything known previous to or during the war. It may be said that we are just beginning to appreciate the advantage of the Panama Canal as an instrumentality for Pan-American commerce. In the calendar year 1920, the net tonnage of vessels passing through the canal aggregated $10,378,265$ tons as against 6,919,149 net tons in the calendar year 1919 .

The activity of the present Shipping Board and the aforesaid sympathy of the Administration for overseas commerce gives promise of legislation favoring American shipping interests, which is absolutely essential for the successful transportation of our manufactured exports and the bringing home of the various raw materials and diverse 


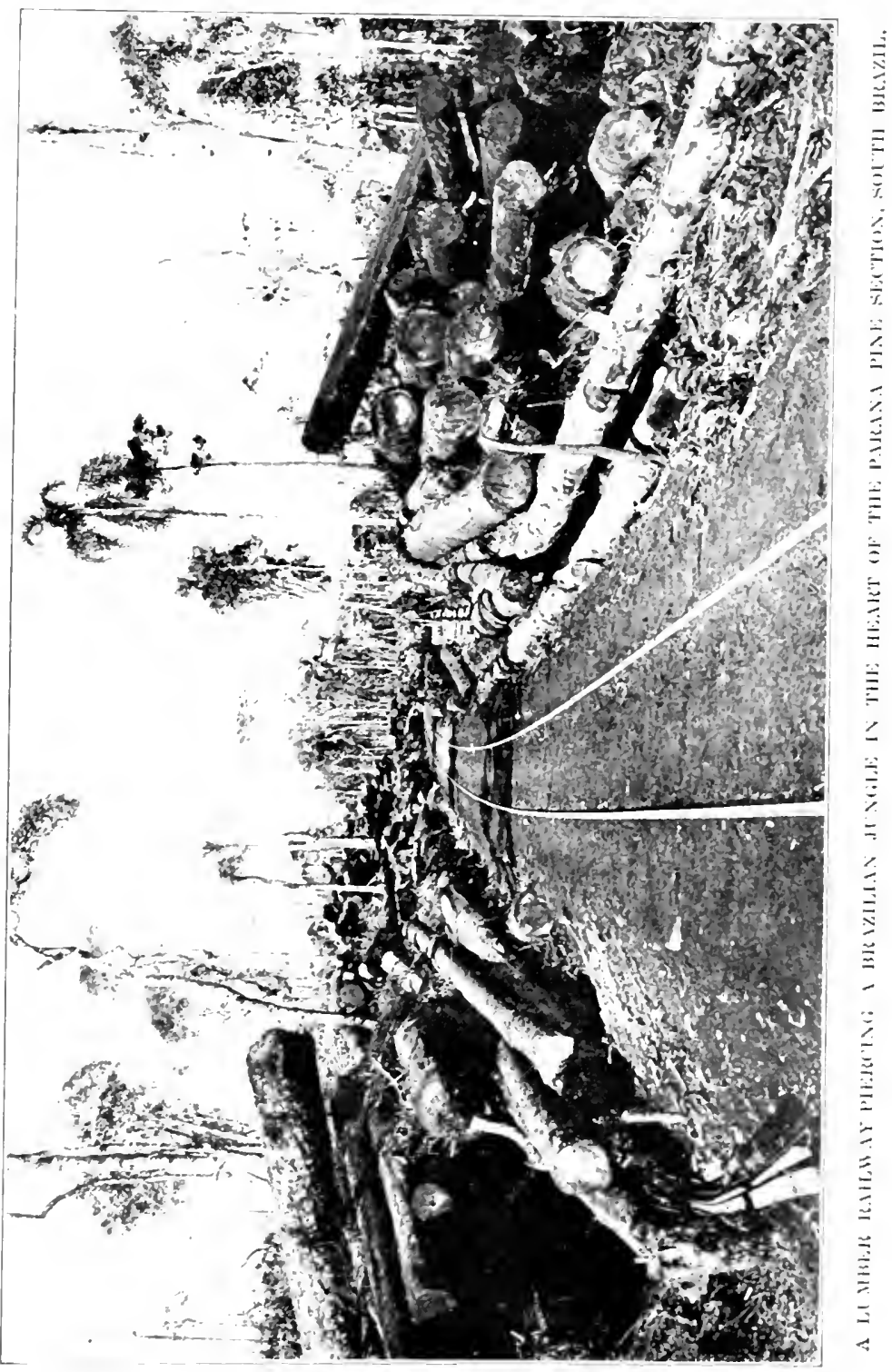




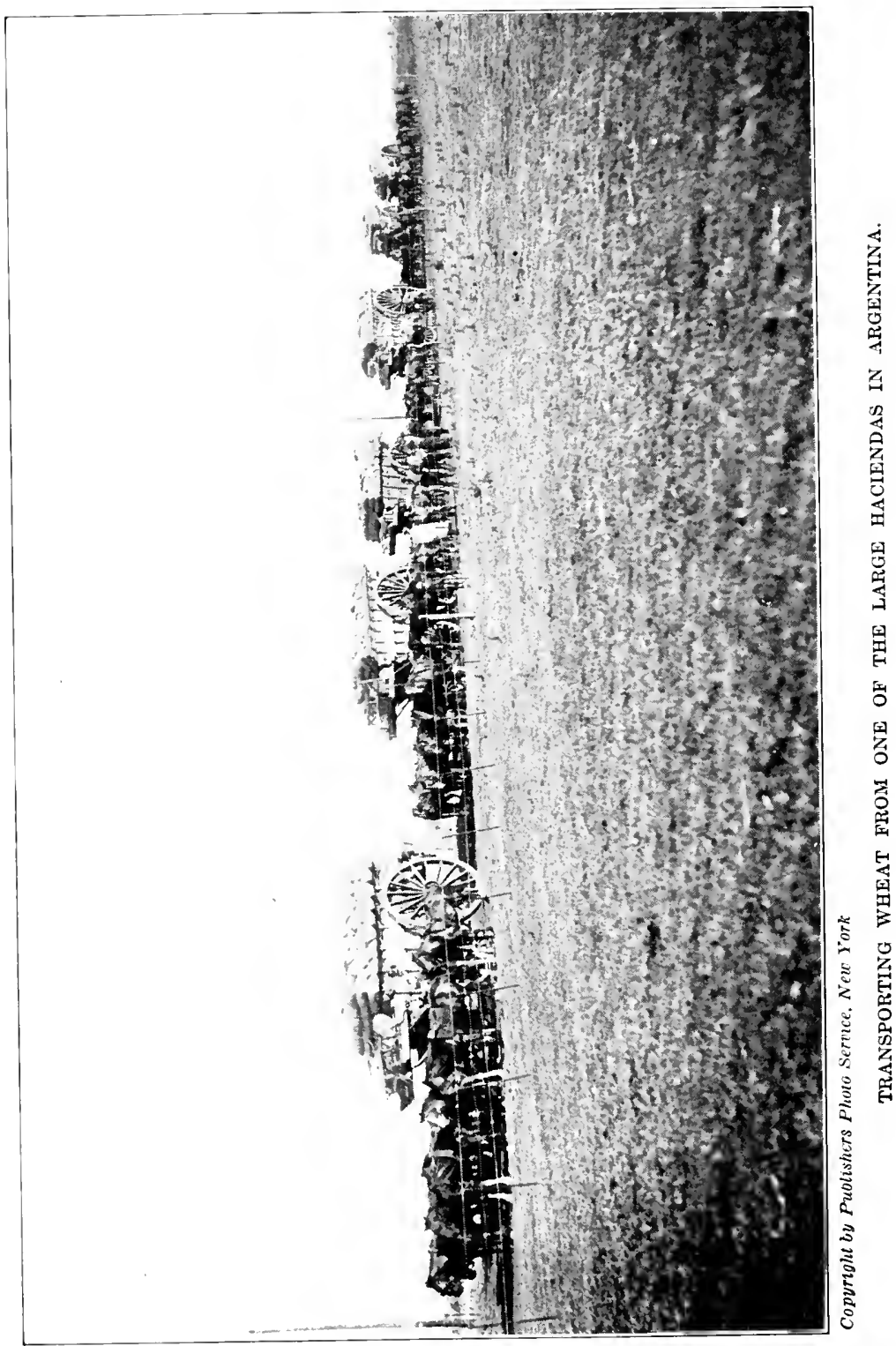


imports from forcign eountries required for the up-building of our industries and national life.

In spite of the fact that tariff legislation and diseussion. during the year 1920 has tended to create certain forcign antagonism, despite the fact that high protective tariff at this time of changing conditions tends to disregard the vast investments of our country in foreign lands, there are indications which lead one to believe that the good sense of Amerieans will predominate over political partisanship and preference, and that tariff laws will be passed adapted to foster and to develop rather than to retard and nullify the many fundamental aetivities just mentioned for the promoting of American commeree.

Given these new supports for our foreign trade, there are still further essentials needed for winning South American confidence and gaiming a permanent foothold among these progressive peoples, whose continent is on the threshold of a vast awakening.

It is of prime importanee for the welfare of the United States, as well as for these nations themselves to give aid to these republies, both by capital and by service. It is important for the United States to gain tangible visibility in Soutl Ameriea by the actual presence of American capital, not in Ameriean banks simply, but also in general business enterprises. It is essential for our business houses to open brameh offiees and earry stocks in South Ameriea, to invest in their bonds and publie utilities, to furnish capital for South American railways, port-works and irrigation enterprises, to assist them by funds as well as by engineers to tumnel their mountains, to open up their mines, to fumish eities with electrical power for public service work, to build packing houses and meat refrigerating plants, and in general to assist South Ameriea to develop her latent resources and industries.

In no other way will Ameriean business gain a foothold in Tatin America more quickly than by the use of eapital eombined with s.rmpathetie coöperation with these peoples in the development of their rieh continent. 
That trade follows the dollar is a truism. South Americans are Latins by heritage, and their traditions differ from our Anglo-Saxon ones, but South Americans are as human as are the Chinese, or the Egyptians, or the East Indians, or any other race when it comes to giving a preference to those who pour money into their country's development. One needs only to observe the hold of the Englishman upon Argentina through the millions of pounds spent on railways in that country to realize the value of money investment as a pledge for future trade.

It is surprising even to first travelers in South Amcrica to note the way in which forcigners have gained a foothold in their enterprises. Why do not the South Americans do these things for themselves, one asks. Why call in foreign capital and foreign leadership in relation to such enterprises as furnishing hydro-electric power to run the tramways and light plants of such important cities as Rio de Janeiro and São Paulo? Or for packing house plants in Argentina and Brazil ?

Why has the Peruvian Corporation with its British backing gained control of the great railway systems in Peru? What has brought American capital so successfully to invest and promote large nitrate and copper interests in Chile and Peru?

The answer to such queries lies far back in the historical and racial background of South America. For centuries this country lay beneath the spell and control of medieval Spain and Portugal.

The Spaniards and the Portuguese of the sixteenth century were great explorers, hardy adventurers, and born to endure hardships of the severest kind on sea and land. But they were not colonizers as were our early American settlers. Agriculture and the routine of daily toil on farms werc repugnant to them. These early gentlemen adventurers, exploiting chicfly the country's precious metals, caring only for the treasure of South America for themselves and their kings in the old country, gave South Amcrica a bad start as far as internal, national, industrial 
and agricultural development was concerned. Furthermore, the natural proclivities of the Latin race for polities, for gentlemanly pursuits, for the literary and artistic side of life were encouraged at the expense of training in the practical utilitarian enterprises primarily needed to eonquer the land and to erect industrialism. Consequently, when these states threw off the yoke of the mother countries in the early days of the nineteenth century, they found their republies with an intelligent and cultured class at the summit of society, with no middle class, and below a more or less ignorant and primitive laboring population composed largely of Indians and mestizos, with many negrocs in the tropieal sections. Altogether the population was like helpless children in the midst of their riches of natural resourees, which required above all the modern arts of science and modern industry to unloek their treasures.

It was natural, therefore, for Latin Americans to turn to the British, to the Germans, and to the North Americans, not only to furnish the mechanieal appliances, but also the means and the men with which to establish the basic foundations for their material prosperity. While these countries can boast of great patriots like Bolivar, Valdivia, San Martin and Bartolome Mitre, they have lacked such leaders as Fulton, and Morse, Edison, and Harriman. To-day in the larger republies like Peru, Chile, Argentina, Brazil and Uruguay, investments are practically as safe as in the United States, since revolutions of any moment have been conspicuous by their absence in these republics for many years. The $\$ 500,000,000$ or more of American investment in looms to South America may well be doubled to the mutual advartage of both countries.

The opportunities for showing South Amerieans that we believe in them and want their trade at present are great and none of them more important than the opportunity of large Ameriean combines to assist these South Ameriean republies in a finaneial way, taking in return both excellent seeurity and the promise of future trade. Markets follow financial investments. 
Another necessity in gaining commercial standing in South America lies in the realization that trade must go both ways between the northern and southern portions of this continent. South America has invaluable products and raw materials to send to us, such as the copper, nitrates, and animal products of Chile; the wheat, wool, hides and meat products of Argentina, Uruguay and Patagonia; the copper, sugar, cotton, petroleum, and alpaca of Peru; the tin, silver, and other minerals of Bolivia; the cocoa, ivory, nuts, hats and rubber of Ecuador ; the rubber, coffee, timber, sugar, leather, and manganese of Brazil; and the cocoa, coffee, copper, rubber, hides, bananas and metals of the northern Caribbean republics.

In return these nations want our manufactured products of all kinds. They need our agricultural and railway machinery, our chemical products, our automobiles, our electrical appliances and tools, our industrial equipments for mills and factories, and also our technical experts and engineers to assist in the construction of their new mechanical, agricultural and mining establishments.

There was never such an opportunity for this reciprocity of trade as at present with new steamship lines, both for passengers and cargo down the West Coast between New York and Valparaiso, and new lines of ships inaugurated down the East Coast, together with other sailings between New Orleans and the West Indies and South American Caribbean ports, and to the Pacific Coast through the Panama Canal.

The British follow their traditional method of winning trade by sending commissions and delegations in their own ships to Chile and to other countries, using the means of friendly acquaintanceship between business men-a tremendous leverage, in gaining South American trade.

It must be remembered also that sentiment and favorable regard born of knowing the people with whom we trade are vital factors in securing commercial footholds in Latin America. It is necessary for Americans to study the problem of what South Americans want from us quite as much 
as to plan what we want to sell to them, if we expect to build up a strong, permanent foreigm business with theso nations.

Unless South Ameriea as well as North America prospers by our trade relationships we cannot in the long run bo suceessful. It is eneouraging to note that our import as well as our export trade with South Ameriea has been rapidly inereasing, as the following statisties will show.

Total value of merchandise imported from and exported to Sonth America by the United States during September and tho nine months ending September, 1921, compared with corresponding period of the preeeding year:

Month of September, 1921

\begin{tabular}{l|r|r}
\hline \hline & 1921 & \multicolumn{1}{c}{1920} \\
\hline Imports.............................. & $\begin{array}{r}\$ 17,092,114 \\
13,913,116\end{array}$ & $\begin{array}{r}\$ 62,534,534 \\
54,470,689\end{array}$ \\
\hline
\end{tabular}

Nine Months Exding with Septexber, 1921

\begin{tabular}{|c|c|c|}
\hline & 1921 & 1920 \\
\hline $\begin{array}{l}\text { Imports. } \ldots \ldots \ldots \ldots \ldots \ldots \ldots \\
\text { Exports } \ldots \ldots \ldots \ldots \ldots \ldots \ldots\end{array}$ & $\begin{array}{r}\$ 224,047,977 \\
228,485,942\end{array}$ & $\begin{array}{r}\$ 637,608,910 \\
431,552,496\end{array}$ \\
\hline
\end{tabular}

Twelve Months Ending June 30.

\begin{tabular}{|c|c|c|}
\hline & 1913 & 1921 \\
\hline 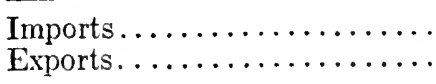 & $\begin{array}{r}\$ 217,734,629 \\
146,147,993\end{array}$ & $\begin{array}{r}\$ 183,249,987 \\
523,450,650\end{array}$ \\
\hline
\end{tabular}

Allusion has already been made to the faet that the South Ameriean is ruled more largely by sentiment than 
are the people in the colder climates of our Anglo-Saxon land. Feelings lie near the surface in Latin America as they do in Japan. Criticism of South American habits of life or business procedure is inimical to gaining trade with these people. Salesmen and advertisers dealing with South America should remember that as a rule there is no color line among these republics and that the attitude toward women is different by tradition than it is with us.

It should alsolbe remembered that a strong Oriental strain permeates South America, having been inherited from Moorish ancestors in Spain and Portugal t'arough the mingling of the Moorish races with those of the Iberian Peninsula for upwards of eight centuries.

When, therefore, the South American shudders at talking business with the brusque directness of the Northerner and requires politeness and gentlemanly deportment as an introductory means to talking business the North American will do well to fall into line, and "when in Rome do as the Romans do." The adaptability of the Germans has greatly assisted their enterprises in winning South American trade. They have studied carefully the South American's temperament, his wants and his character. They have learned Spanish and Portuguese before going to these republics and have considered seriously the question of the "what" and "how" of South American business.

If the North American manufacturer or exporter in sending his agents to South America, or in his first letters, or through his personal contact with these people always will keep in mind the necessity of putting himself in the South American's place and securing the mental point of view of his customer he will seldom have difficulty in obtaining business or conducting it. Half of the trade errors with South Americans have occurred through this inability or inattention on the part of American business men.

A vital essential in winning Latin American trade also resides in the proper adjustment of our methods of business to suit the Latin American desires and temperament. 
This topic is hackneyed enough, but so long as we are losing South American trade by our indifference to certain details of business intercourse and procedure it is a subject that must be considered.

In spite of the enthusiastic admiration of North America by South Americans by reason of the results of American participation in the late war, the most recent observations in these southern republies prove that no amount of admiration and sentiment will take the place of business methods approved in South America in wimning trade. Busincss is business in South America and when it comes to economics the South American will favor Germany, France, England, Japan, or any other country which caters most carefully to his national demands and idiosynerasies.

The situation along this line was expressed by a business man returning from South America whose views were published in the New York T'imes. Among other things he said:

It is unfortunate that American business men have not done all they should have done to follow up the great wave of admiration for their eountry which has swept over South Ameriea. The total volume of $\Lambda$ meriean trade with South America is greater than it was before the war, but the faet remains that Americans have not been able to hold all the gain which the war brought to them. Importers in South Ameriean republies have turned again not only to Great Britain but also to Germany. This is true of some of the most pro-Ally business houses in Argentina and elsewhere. It means that German methods of doing business in South America are so astute, the prices quoted by German houses so low, that anti-German sentiment is all too frequently not proof against the hope of business advantage. Orders are being placed by South American houses for German goods even when there is great uncertainty as to when they can be delivered.

I venture to prediet that if the Germans ean get raw materials they will get baek 90 per eent of the business which they had in South $A$ meriea before the war, unless they are met by $A$ meriean and other competitors with methods like their own, or by other methods which may prevent them from forging ahead by appliea- 
tion of the business methods which have served them so well in the past. You have no idea of the thoroughnes's with which the Germans work. The English have of late become more and more formidable competitors, but the Germans are still preëminent as salesmen. It isn't that the South Americans like them particularly. They don't. They simply buy where the buying seems bes̀t.

The Germans study native South American idiosyncrasies with minute care. For instance, when an Argentine merchant becomes a proud father the German merchant with whom he has had dealings loses no time in sending him a card of congratulation. That tickles the Argentine, and it is more than likely that, other things being equal, it will dispose hin kindly toward the Teuton when the time comes for placing orders. Some Englishmen are learning how to do that sort of little courtesy-but how many American business men would think it worth while?

The business methods which Americans need to watch have to do also with the study of the hours of doing business in South America, which in many sections are quite different from the business hours in the United States; salesmen's methods, requiring far more courtesy and deference than at home; and having regard for "mail days" when calling upon customers as well as discarding haste and bustle.

Legal formalities should be taken up with the American Consul when opening business houses, branches, or agencies, together with an effort to keep out of Latin American courts; a study should be made also of custom-house fees and procedures. Banking methods most desired by Latin Americans should be studied, never forgetting the inevitable fact that South Americans require credit, packing and prompt attention to orders from us equal to the service they have been accustomed to receive from European countries.

Although there is in certain republics of South America some jealousy of the United States (los yanquis) there is no widespread feeling of hostility in South America towards us. On the other hand, we believe that for the most part 
there is a decided admiration for the industrial and business efficieney of North Americans.

If such essential points as the foregoing are emphasized by our exporters and manufacturers, there is no reason why the volume of trade between the two Americas should not mount up inereasingly. It should always be remembered, however, that to win South American trade we must consider that the capture of South American markets is dependent upon the winning of the South American heart and his respect, as well as the buying and selling of goods. This will require the combined best efforts and thought of the manufacturer, the export manager, the salesman and the advertiser. Let no one doubt, however, that this combined effort will pay abundantly in future results.

\section{COMPARATIVE INFORMATION RELATIVE TO TIIE EXPORT AND IMPORT BUSINESS OF SOUTH AMERICA}

The following facts reveal the general trend of foreign trade, together with the leading products of South America, with five of the chicf nations interested in commeree, with these republics for the year 1917 (the last year for which reports are made up from various countries), and also facts eoncerning German trade with South America for the prewar year of 1913.

Figures for the years 1918 and 1920 would show considerable inereases, but the general comparative ratio of South American trade with the countries named has remained approximately the samc. As to the ycar 1921, there has been a falling off in both the export and import trade of South Ameriea, practically with all of the countries named, the condition of money exchange working certain hardships to the trade of the United States with South America: 
Argentina

Exports: Meat, wheat, flax, corn, oats, quebracho.

Imports: Foodstuffs, iron and steel manufactures, oils and chemicals.

1917

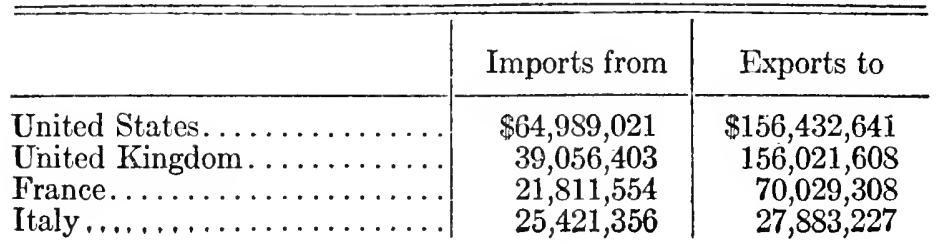

1913

Germany.............. $\$ \$ \$ 80,996,103 \quad \$ 60,024,558$

\section{BRAZIL}

Exports: Coffee, rubber, cocoa, sugar, hides, manganese.

Imports: Coal, wheat, steel products, paper, cement.

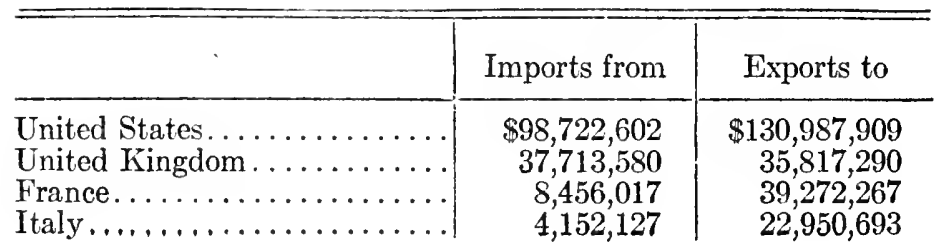

1913

Garmany .............. $\$ 56,973,330 \quad \$ 44,333,640$ 


\section{Chile}

Exports: Nitrate of soda, copper, wool, iodine.

Imports: Textiles, coal, steel, explosives.

\section{7}

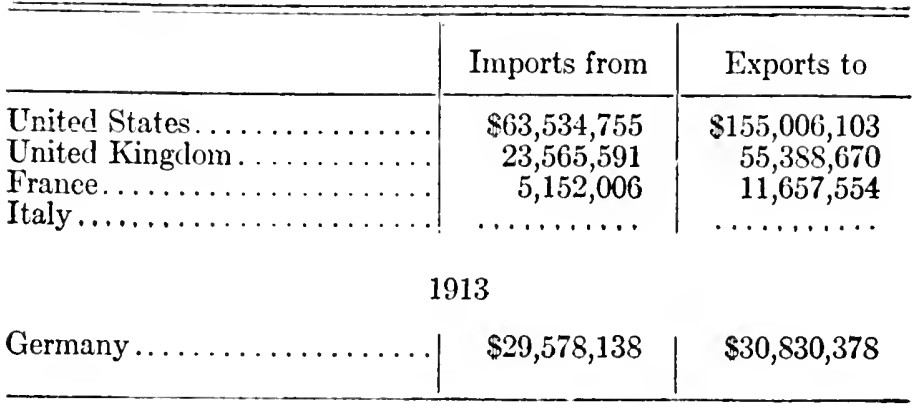

\section{Bolivia}

Exports: Tin, rubber, antimony, copper, tungsten.

Imports: Textiles, steel, breadstuffs, explosives.

\section{7}

\begin{tabular}{|c|c|c|}
\hline & Imports from & Exports to \\
\hline 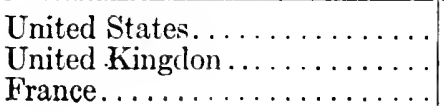 & $\begin{array}{r}\$ 4,355,285 \\
1,583,821 \\
286,400\end{array}$ & $\begin{array}{r}\$ 22,193,030 \\
35,225,550 \\
1,672,630\end{array}$ \\
\hline
\end{tabular}

1913

\begin{tabular}{l} 
Germany $\ldots \ldots \ldots \ldots \ldots \ldots \ldots$ \\
\hline
\end{tabular}




\section{Peru}

Exports: Sugar, cotton, copper, wool, oils.

Imports: Coal, textiles, wheat, lumber, meats.

\section{7}

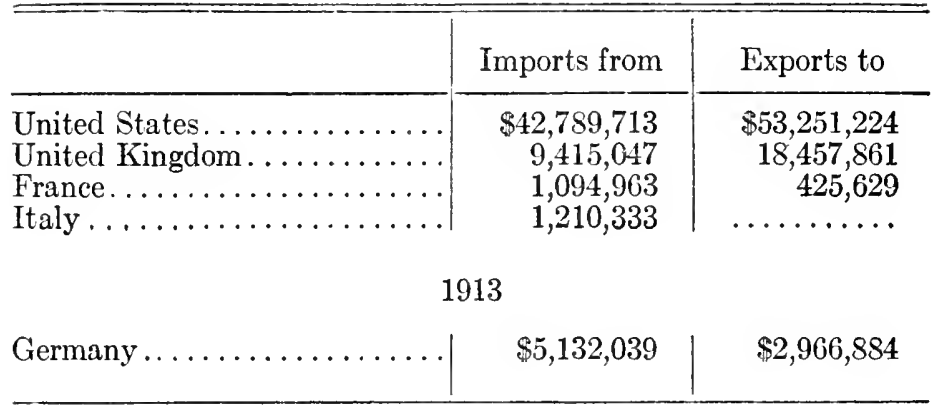

\section{ECUADOR}

Exports: Cocoa, panama hats, gold, coffee, hides, ivory, nuts. Imports: Textiles, foodstuffs, machinery, drugs, hardware.

\section{7}

\begin{tabular}{|c|c|c|}
\hline . & Imports from & Exports to \\
\hline 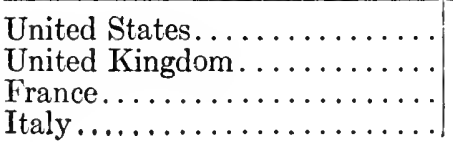 & $\begin{array}{r}\$ 5,942,502 \\
2,463,951 \\
325,081 \\
195,283\end{array}$ & $\begin{array}{r}\$ 12,794,467 \\
109,215 \\
1,449,585 \\
142,652\end{array}$ \\
\hline \multicolumn{3}{|c|}{1913} \\
\hline Germany......... & $\$ 1,563,129$ & $\$ 2,627,353$ \\
\hline
\end{tabular}




\section{Colombia}

Exports: Coffee, gold, bananas, hides.

Imports: Textiles, steel, lumber, machinery.

1917

\begin{tabular}{|c|c|c|}
\hline & Imports from & Exports to \\
\hline 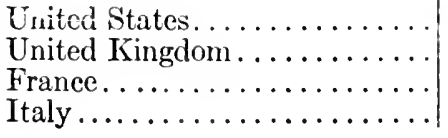 & $\begin{array}{r}\$ 14,500,000 \\
7,000,000 \\
500,000 \\
400,000\end{array}$ & $\begin{array}{r}\$ 30,000,000 \\
700,000 \\
450,000 \\
150,000\end{array}$ \\
\hline \multicolumn{3}{|c|}{1913} \\
\hline Germany $\ldots \ldots \ldots \ldots \ldots \ldots$ & $\$ 4,012,000$ & $\$ 3,216,200$ \\
\hline
\end{tabular}

\section{VenezUela}

Exports: Coffee, cocoa, balata, hides, gold.

Imports: Textiles, drugs, flour, machinery.

1917

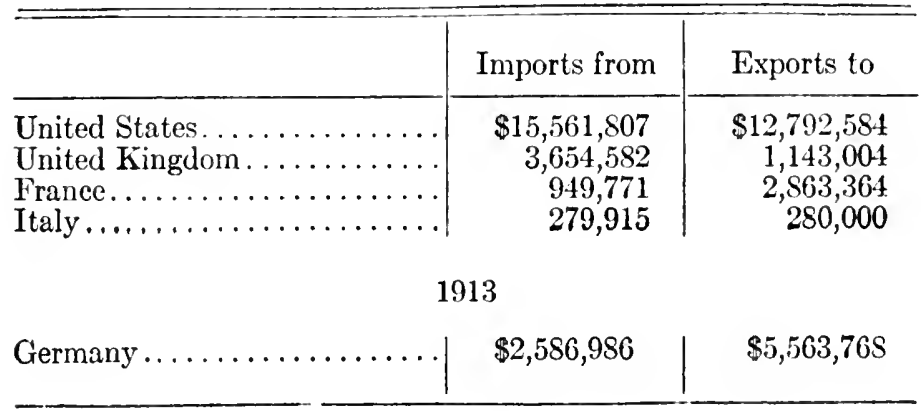




\section{URUGUAY}

Exports: Wool, meats, hides.

Imports: Foodstuffs, hardware, naval stores, machinery.

1917

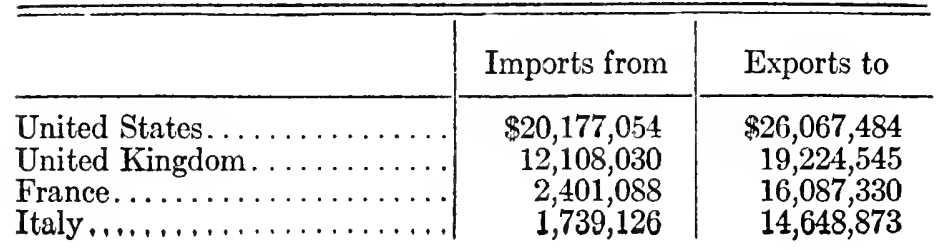

1913

Germany ............... $\$ \$, 076,714 \quad \$ 13,807,580$

\section{Paraguay}

Exports: Hides, yerba maté, petit grain, quebracho.

Imports: Textiles, foodstuffs, machinery, chemicals.

\begin{tabular}{|c|c|c|}
\hline & Imports from & Exports to \\
\hline 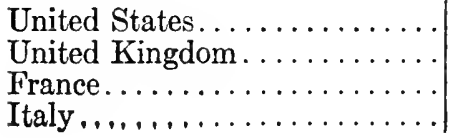 & $\begin{array}{r}\$ 1,515,604 \\
2,609,346 \\
473,687 \\
500,000\end{array}$ & $\begin{array}{r}\$ 358,911 \\
58,953 \\
311,928 \\
321,575\end{array}$ \\
\hline
\end{tabular}

1913

Germany ............... $\$ 2,176,606 \mid \$ 1,198,685$




\section{British Guiana}

Exports: Sugar, rum, balata, rice.

Imports: Textiles, flour, fertilizers, machinery.

1917

\begin{tabular}{l|c|c}
\hline & Imports from & Exports to \\
\hline United States...................... & $\begin{array}{c}\$ 5,910,238 \\
4,560,978\end{array}$ & $\begin{array}{r}\$ 770,519 \\
9,171,874\end{array}$ \\
\hline
\end{tabular}

\section{French Guiana}

Exports: Cocoa, phosphates, gold, hides.

Imports: Live stock, textiles, provisions.

1908

\begin{tabular}{l|c|c}
\hline & Imports from & Exports to \\
\hline United States............ & $\$ 33,136$ & $\$ 335,174$ \\
\hline
\end{tabular}

\section{Dutch Guiana}

Exports: Sugar, rum, cocoa.

\section{Total South Americax Trade}

1917

\begin{tabular}{|c|c|c|}
\hline & Imports from & Exports to \\
\hline 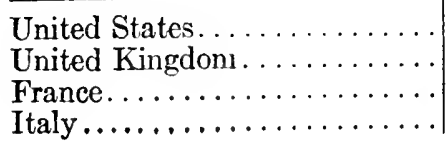 & $\begin{array}{r}\$ 325,222,313 \\
134,005, \sim 43 \\
28,993,661 \\
33,898,140\end{array}$ & $\begin{array}{r}\$ 603,0 \$ 5,486 \\
303,114,645 \\
145,615,217 \\
68,177,022\end{array}$ \\
\hline Germany.... & $\$ 187,177,377$ & $\$ 163,913,870$ \\
\hline
\end{tabular}




\section{CHAPTER XXIX}

\section{CARRYING AMERICAN IDEALS ALONG THE ROUTES OP WORLD TRADE}

No undertaking has ever succeeded greatly that has had a merely sensual or selfish aim.-Emerson.

Along with this widening of the American's interest in a world-wide activity of trade, there comes the inevitable possibility of carrying his ideals with his ideas around the world. Although "business is business" in China or Brazil, as it is in New York or Chicago, nevertheless the personality of the business man, his motives, his characteristics and his idealism-all these are contagious influences and are quite sure to be contributed in more or less degree to those with whom he enters into trade.

What can the American contribute through his idealism along the routes of foreign commerce? Is there something intangibly subtle and vital in our Americanism that is worth while to be passed along through contact with other people? If we gain much from the old world and from Latins and Orientals, do we not also have the privilege of giving much of that peculiar quality which has always set apart the American and made him in the minds of many peculiar and distinctive?

"I am a democrat and a dreamer," were the words with which I heard one of our prominent American foreign traders characterize himself. He was the head of a large and influential firm, closely related to contemporary life at home, and interrelated with many trade lines reaching out to the ends of the earth. His whole eareer had been involved in a myriad of business interests and details worlds 
removed, as it would seem, from the land of dreams. One would have ealled this man successful, practical, and highly efficient, but hardly an idealist, yet knowing the man intimately would prove to any observer that he was an idealist-a utilitarian idealist.

In a land where the word utility is ubiquitous, and in an atmosphere where a dreamer is supposed to be a visionary, the union of the two in one indiyidual would seem at first to be an irreconcilable anachronism. I believe, notwithstanding, that the idealism of the twentieth eentury Ameriean is a very real thing, and that it has never been more aceurately designated than in a phrase written by Prof. John R. Commons in an article contributed to the Intercollegiate Magazine in 1909: "Utilitarianism is the democracy of idealism."'

It is this inexplieable idealism in the midst of the practical, the marriage of the imagination with modern applied science, the secularizing of the mind and the human spirit, and the bringing out of dreams into the light of a democratic day, that distinguishes present day America. No other country by location or tradition las been so conducive to the drawing out of a useful idealism, or to making the mystic and the scholar practical and serviceable to tho community. The vast distribution of wealth, the marvels of scientific exploration and industry, surpassing the wonders of the Egyptians, the strain of the Puritan, all set in an atmosphere of demoeratie obligation, remarkable business instinct and coöperation, have furnished an alluring and enchanting field for the development of a quality of idealism heretofore uncommon among men.

This tendency uniting ideals with praetice and bridging the gulf between dreams and action is seen in a hundred ways, and it is far more general than is usually appreciated. The word spiritual, for example, is rapidly losing its former pious significance, and is becoming naturalized in the society of other words connected with the higher nature of man in his everyday life. American religion must not simply be good, it must be good for something. We are not so much 
inclined to say "The Beautiful and the Good," but with Goethe, "The Beautiful is the Good." The scientist for a time seemed to be getting the best of the humanist and the scholar, but there are abundant evidences at present of the secularizing of all edueation and attaching the specialist in the theories of economics, politics, and social and applied science especially, to the chariot wheels of modern govern. ment, modern business and modern philanthropy.

Indeed the shuttle runs back and forth with remarkable swiftness and ease between the real and the ideal worlds. Ideals in the loftiest reaches of democracy, the purification of political life, both in the nation and municipality and in the honest conduct of trade, are becoming regnant without the reformers and the reformed recognizing them as ideals. They often masquerade under the guise of "good government" or "good business." Ideals of regulation in business and trade and the inter-relation of vast corporate interests which were like the political party platforms before election of twenty-five years ago (counsels of perfection to be edited but not executed), have in these days come so near actualization that even the sins of the fathers are being visited upon the children of "big business." When the laws for correction and reform of abuses in trade and organized occupations do not come fast enough, we form commissions to investigate, and from the inexorable searchlights of these latter idealizing bodies nothing and no one is exempt, from the biggest insurance company to the biggest revivalist, and what the investigators miss in details of depravity the newspapers supply.

These utilitarian ideals are in fact about the most common and prominent things amongst us at present. As they sweep the ranks of society we do not always call them ideals. As a nation we abhor the trail of pharisaism and the semblance of piety. We idealize our character under the head of "standards of conduct," or "respectability," but it is fairly safe to say that there is no place on God's footstool where moral ideals of conduct are more universally respected or where the absence of them is more fatally 
blighting to reputation or suceess than in the United States.

Strange as it may seem, it is in the person of the American business man, practieal, level-headed, all business, that this current of the ideal is elearly, often most elearly, seen. His big-heartedness is often in proportion to his blunt directness. Get a bit below the surfaee and you will find frequently a nature steeped in sentiment.

At the call of distress, either at home or abroad, his purse strings are loosened with a prodigality that marks the fanatic. In his business office he may be as austere as the statue of Memnon, but in his home or in company of his friends he is as ful of idealistic feeling and often of romanticism as the East Indian schoolboy.

The average American man of affairs, as soon as he gets past the persiflage of group conversation to his heart-toheart talk with you in quiet, will lead you to the little holy of holies of his own personal ideals, to some fine worth while issue, without which, notwithstanding his dollars, his sky scrapers, and his automobiles, he would be poor indeed.

This vision seen in and through his work is the only thing that makes the Ameriean's inveterate toil something else than drudgery. Save to the aged clerk with his silver hair, and those destined followers in the race of life whose duties are the bars of habit, work in Ameriea is not a "squirrel's wheel." The English Wesley once said, "I ean plod." The American says, "I can plod if I ean see something ahead to plod for."

In this country of vast dreams and huge fulfillments idleness is a rusty sword in the soul, but work that has no point to it turns the iron round, and is even more excruciating. The resiliency of the American spirit is proverbial. It is born of hilltop visions of work that is profitable to do, of new empires beyond the sea to conquer, the endeavor that gets one on.

Everything must be charged with a more or less useful 
idealism. A business man said to a elergyman, who urged him to join his ehureh,

If there is anything I can do that will really count, I will come in, but I don't want to join the church just to sit around and sing.

The United States is probably the most distasteful atmosphere imaginable for the man without a "job"; it is also almost a prison house to the man who feels that his job is not worth while. It is this intuitive sense that he has taken hold of a great work that explains much of the American's enthusiasm and unquenchable buoyancy. Dr. Eliot is reported to have said at one time concerning Mr. Roosevelt, that he had never "grown up." Was it not, however, in that ever-l'enewed idealism, in the pushing power of undisillusioned youth, as mighty as it is at times mistaken, in that resistless energy born of new and unfulfilled dreams of human progress, that our late ex-President typified the American spirit? Utilitarian idealism is the reign of a high ideal in the midst of useful labor. It is doing a practical thing with a spiritual motive.

It was with this thought of the ideal penetrating the real in the American temperament that we asked a prominent manufacturer engaged in sending his products the world around, what he considered to be the "leading business ideal" of the American. "The leading business ideal?" The manufacturer slowly repcated my question after me. He had just returned from a month of travel among the branches of the firm in the Middle West, and it seemed an opportune time to get from him a comprehensive answer. He placed his cigar on the corner of his desk and his eyo followed down the lofty eorridor of skyserapers that darkened William Street:

In a word, I should say, the square deal-both ways.

This man who answered my question was not an apostle of "big business"; he was not a socialist; he was not a 
dreamer. He was a typical business man of moderate means as fortunes in Ameriea go to-day, and possessed with perhaps somewhat more than the average thoughtfulness. He was of native stock, without hyphen in his name or his nature, a self-respecting eitizen and householder. He was the kind of man who helps to form the great national vertebra of the United States.

Was this popular statement of democracy something the man had inherited? Was it a part of that more or less loosely arranged sentiment of equality that floats all too frequently in the atmosphere of the eountry? What was behind the statement? What did he mean by "the square deal"?

Square-dealism is coming to mean a very real thing in the United States, something far more useful and practicable than a lawyer's glittering generality. To the college boy it means that clcan athleties and clean scholarship and clean living are far more likely to bring him recognition and honor among his fellows than their opposites, and that trickery and dissipation that were passed off as cleverness and marks of manliness twenty-five years ago, now stamp him as an undesirable in college and load him with an oppressive heritage for a start in business or professional life. To the congressman sustained by a rising public opinion in morals of states, the square deal has meant the repeal of the Panama Canal bill, in the interests of a square deal, not for ourselves simply, but also for our national neighbors. To the modern self-respeeting business man it has meant an inereasing ambition to be well thought of by one's business associates, both at home and abroad, to gain and to hold ereditable standing, and to maintain one's self-respect in the world of affairs. To the tradesman it signifies the reputation for just dealing, to give for a dollar a dollar's worth, and the growing belief that to make a eustomer is better than to make a sale.

A real estate man put the matter thus:

Most men desire to live so that other men say, 'His word is as 
good as his bond.' Most of the men I know prefer to have other men think of them as good rather than clever. They may desire to merit both of these qualifications attributed to them, but would prefer the former.

The friends of the late Charles Frohman stated, with justifiable pride in their associate, that a contract was never necessary between him and his workers, that Frohman's word was sufficient.

These ideals of square business dealing which have become more and more a fact in the United States, need to be applied more rigorously than ever before to all matters involved in foreign tradc. It has been too often the fact that methods of business conducted upon strict integrity at home have not been so easy to earry to foreign lands. The fact of distance has seemed to complicate the code of morals of business men and this is not true simply of Americans. For example during the business depression of 1920, the matter of cancellations of goods and the looking out for number one, sometimes regardless of legitimate trade, were characteristics of certain firms not simply of one, but of many nations. In this new day of world-wide industrial and commercial interchange of thought, of products, and of life in general, there should be no stoppage of right ideals and right codes of business at shore lines. A deal that is illegitimate and crooked in domestic trade should be considered unjustifiable in foreign trade. On the other hand, every bit of progress which has been made to make these business relationships clean and straight at home, should bc carried along the routes of commerce wherever our business activities go.

America is coming of age in a period of unexampled opportunity in world affairs. Her fancied isolation has been rudely shattered. The present world conflict, with its earth shaking influences, by its tremendous effect upon our cconomic, industrial and emotional life, already has awakened the nation at a destined moment to the fact that 
we ean no longer exist on a continent apart, but that wo have become by the arbitrament of time and tragedy of circumstance a part and pareel of world responsibility. America is summoned to eultivate an aptitude for altruism in her young manhood, and her future as a great or small civilization hangs upon her present choice. Henceforth, if we are to make the gift of our forefathers-that saered deposit of freedom-meaningful, we must be ready with foresight and wisdom heretofore unsummoned to take our burden of world obligation, as well as to prepare to caro for the enlarging interests that are our own. Whether business ideals and business interest which are particularly American shall be carried through such influenees as a League of Nations, a plan of disarmament, through our diplomatic or consular representatives, or through those trade ambassadors who reach even more intimately every part of the earth, the main issues persist-shall we make world trade a part and pareel of domestic trade in that the same standards of equity and justice shall be present whether the Ameriean is dealing in Madagasear, Shanghai, Valparaiso or New York?

Our fathers brought to our shores from Europe in their frail sailing ships a precious endowment with which to inform and to actuate the young republic. They were the ideals of political and religious freedom. These ideals have not yet been fully perfected in our hands, but they have been fostered and extended in a legion of ways among our own eitizenship as well as among those who have sought homes on our shores. These ideals have permeated all our institutions. They have made an atmosphere for American hopes and American enterprises. We of to-day may be called upon in the new morning of America's maturity, in the very dawn of her spiritual strength, as the unhostilo representatives of her wealth and insight, to send back to Europe and the old world this priceless spirit of idealism, not in the terms of battleships, but in the language of prosperity and trade, not wearing the insignia of military 
conquest, but clothed in the garments of peaceful and legitimate business.

"O mighty Lord of Trade's high running sea

Grant us an elce of that distant main ...

Beyond dark waves of danger to attain

The coast of Courage, strand of Bravery.

Grant an assurance and a hope more free,

That over stiller waters we may gain,

At length, a vaster vision, not in vain,

Of Thine eternal opportunity.

Prepare a highway in this wilderness of wanton ways of trafinc...

A new heart of love and law and justice in the mart;

A loftier view of commerce, limitless . . .

That sees therein no end Thou wouldst not bless

No consummation other than Thou art." 


\section{INDEX}

Advertising, export, its necessity and how accomplished, $41 \mathrm{ff}$.

foreign advertising courses, 107.

neriodicals to utilize, 243.

Africa, commerce with the U. S., $333 \mathrm{ff}$.

deseription of markets, 333, 347.

South, bibliography of, 121 . diamond and gold mines of, 345 .

economic conditions and resourees, $338 \mathrm{ff}$.

papers and periodieals as advertising media, 247.

structure of country, climate and resourees, 338 . Agrieulture, tractors and motors required in Near East, 330.

Ainseough, T. M., British trade commissioner, compares Ameriean and British trade in India, 298.

Algreria, resourees and commeree, 338.

work of France in, 338.

All America Cables, Inc., cable lines and rates, $158 \mathrm{ff}$.

Ainbassador, British, to Constantinople, quoted relative to Turkish characteristies, 309.

Ambassadors and Ministers, functions and services deseribed, $250 \mathrm{ff}$.
Ameriean Chamber of Commerce, in China, 272.

in Egypt and in Greeee, 332. Ameriean Foreign Trade, direct exporting, $22 \mathrm{ff}$.

the export manager, $24 \mathrm{ff}$.

American Ideals, earricd along routes of world trade, 420,424 .

Ameriean Loeomotive Co.,training employees, $66 \mathrm{ff}$.

Ameriean Tobaceo Co. in China, 281.

American Trade, the commission house, 20.

American Trading Co., training employees, 68.

Ameriean traits analyzed, $422 \mathrm{ff}$.

traits contrasted with Engglishmen, 379.

Argentina, British investments in, 363.

exports and imports of, 114. Armour and Co., training employees, 82 ff.

Arnold, Julian, suggests trade exposition and products needed in China, 279.

Arnold. Matthew, quoted, 315. quoted regarding the East, 307.

relation to American traits, 369.

Asia, can trade westernize her, $307 \mathrm{ff}$.

Asia, Magazine, carrying artieles on China, 82. 
Atlantic Refining Co., training employees, 67 ff.

Austin, O. P., statistician, concerning U. S. manufactures, 2.

Australasia, newspapers and periodicals as advertising media, 247.

Australia, bibliography of, 121. resources and markets, $367 \mathrm{ff}$. sheep, cattle and mineral products, 368.

Austria-Hungary, amount of foreign trade with U. S., 386.

Automobiles, required in Near East, 330.

Baltic, American trade with Finland, Poland, etc., 386.

Banana, the land of the, $396 \mathrm{ff}$. Banks, for financing foreign trade, 171.

National City Bank, 172.

Baroda, Gaekwar of, installing cinematograph machines, 295.

Belgian Congo, description of country and products, 346.

products and exports, 345 ff.

Belgium, work in Congo Free State, 346.

industrial development of, and trade with America, 386 ff.

Billings, Josh, quoted, 39.

Bland, J. O. P., relative to Japanese conditions, 261.

Bolivia, leading products of, export and import, 415.

Bolshevism, in Russia, 349 .

Boston University, courses and plan used in foreign trade preparation, 81 .
Boutroux, Emile, of the French Academy, quoted concerning French characteristies, 225.

Brazil, cable communications with, 155.

exports and imports, 414 . press of, $35 \mathrm{ff}$.

products of, 408 .

British Columbia, forest resources, 365 .

British Guiana, exports and imports, 419.

Britishers, contrasted with Americans in characteristics, $370 \mathrm{ff}$.

traditional conservatism, 378. understanding of, a necessity for trade, 369.

Bulgaria, immigration to United States, 331.

Bureau of Foreign and Domestic Commerce, 57.

quoted concerning trade with India, 301.

supplying late information and statistics, 347.

Burroughs Adding Machine Co., training salesmen, $93 \mathrm{ff}$. Business firms, training for foreign commerce, $61 \mathrm{ff}$.

Cables, All America Cables, Inc., connections and rates, $158 \mathrm{ff}$.

art of using cables, 165.

cables owned by nations, 170 . construction of, 148.

Inter-American, 149.

list of cable companies connecting with LatinAmerica. $152 \mathrm{ff}$.

ownership of cables lines, 155.

privately owned submarine cables, 168. 
Cables, the nerves of foreign trade, $146 \mathrm{ff}$.

Canada, agricultural and forest resources, 365 .

bibliography of, 121.

imports and exports, $366 \mathrm{ff}$. markets with, $364 \mathrm{ff}$.

Caribbean markets, 391 ff.

Central Anerica, inhabitants and labor, 399.

trade with the U. S., 395.

Chambers of Commerce, American, in China, 272.

in South Africa, 341.

in the Levant, 325.

services of, 176 .

Chase National Bank, interest of, in China, 283.

Chile, bibliography for foreign trade study, 118.

cable communications with, $156 \mathrm{ff}$.

Chilean business man quoted, 38.

principal exports and imports, 415.

China, Chinese students in France, 279.

craze to learn English, 185. high-class Chinese quoted, 38. imports from United States, 277.

progress and reaction, 316.

resources and language requirements, 195.

selling motor trucks to, 30 .

strengthening American trade with, $271 \mathrm{ff}$.

trade with America, 276.

transportation in, 278.

China Trade Act, outlined in report of Mr. Dyer, $273 \mathrm{ff}$.

C.I.F. and other foreign trade terms defined and explained, 213.
Commission house, described, $20 \mathrm{ff}$.

Commons, Jolnn R., quoted, 421. Consuls, American, duties outlined, $253 \mathrm{ff}$.

Corse, Frederick M., reasons for trade failure in Russia, 356.

Cotton, Egyptian, 326.

Courses suggested for foreign trade preparation, 105.

Credits, foreign, how arranged and wisdom of, $175 \mathrm{ff}$.

Cuba, agricultural and industrial wealth and markets, $392 \mathrm{ff}$.

Czecho-Slovakia, trading with U. S., 386.

Darwin, Charles, quoted regarding successful life work, 55.

Decalogue, of foreign salesmen, 39,40 .

Department of the Interior, Wash, D. C., training for foreign commerce, 70 fif.

Dewey, Prof. John, describes Chinese, 282.

Diplomatic and Consular Service, work outlined and described, $250 \mathrm{ff}$.

Direct exporting, explained, $22 \mathrm{ff}$.

Dollar, Robert, regarding operation of ships, 134.

Drum, John S., quoted on in. vestment, 9 .

Du Pont de Nemours Export Co., concerning training for foreign commeree, $74 \mathrm{ff}$.

Dutch East Indies, books descriptive of, 120.

Dutch Guiana, exports of, 419. 
Dyer, Mr., of House of Representatives, regarding China Trade Act, 272 ff.

Eastman Kodak Co., training employees, 80 .

Eeuador, chief exports and imports of, 416.

Edge Act, advantages for foreign banking, 403 .

Edison, Thomas, quoted regarding genius, 54 .

why popular in U. S., 371.

Education, American schools in Near East, 327.

Egyptian schools, 334 .

English public schools trainers of British traders, 381.

in Philippines', 289.

Japanese literacy, 296.

Edwards, Amelia B., describes Egyptians, 335.

Egan, Dr. Maurice Francis, connection with treaty for Virgin Islands, 252.

Egypt, character and progress, $333 \mathrm{ff}$.

exports and imports to and from U. S., 326.

new industrial order of, 335.

Emerson, quoted, 51, 420.

on foreign countries, 369.

England, achievements in Egypt, 331.

commerce with Russia, 350. influence on the East, 313.

Europe, suggested bibliography for foreign trade study, $114 \mathrm{ff}$.

trade with the new, $385 \mathrm{ff}$.

Evans, Henry, regarding ma. rine insurance, 138.

Exchange, dollar exchange in Near East, 325.
Exporting, direct exporting explained, $22 \mathrm{ff}$.

the export merchant, $17 \mathrm{ff}$.

things to be kept in mind, 6 . Export trade, a necessity, 52 . Export trade papers, importance as foreign trade media, 245 .

Fang, Dr. Wu Ting, quoted relative to Chinese nature and tendencies, 284.

Far East, The, bibliography for foreign trade study, $117 \mathrm{ff}$.

newspapers and periodicals as advertising media, 248.

Farrell, James A., specific suggestions for handling shipping arrangements, 134 ff.

Financing, Great Britain past master in credits, ete., 364.

Ford, L. C. and Thomas F., quoted relative to England's world-wide investment trade policy, 363 .

Foreign Exchange and Banking, bibliography of, $122 \mathrm{ff}$.

Foreign Trade, actual example of procedure of foreign trade financing, $181 \mathrm{ff}$.

American commerce compared with British in India, 298, 299.

American commerce with Russia, $348 \mathrm{ff}$.

American, historical growth of, 127.

American industrial exhibit suggested for China, 279. 
Foreign Trade, American trade with Africa, 333 ff.

begins with resources at home, 11.

buying agencies of American firms in Near East, 328. cancellation of contracts, 426.

Caribbean markets, $391 \mathrm{ff}$. commerce of $U$. S. in relation to other nations, 13.

commerce with Bulgaria, Serbia, Roumania, Southern $R$ ussia and Persia, $331 \mathrm{ff}$.

comparative export and import business with South America, 413.

coöperation needed, 10 . correspondence, 47. credit vs. cash policy, $175 \mathrm{ff}$. definition of foreign trade terms, 205 ff.

doing busines with the new Europe, $385 \mathrm{ff}$.

East Indian markets, $295 \mathrm{ff}$. far-sighted policy of England, 360 .

financing of, $171 \mathrm{ff}$.

general bibliography, 122.

how foreign shipments are paid for, credits, etc., $173 \mathrm{ff}$.

knowledge of export business required, 12.

knowledge of foreign peoples required, 4.

requirements of, $1 \mathrm{ff}$.

resources and markets United Kingdom of Great Britain, Canada and Australia, $359 \mathrm{ff}$.

rules for foreign traders in India, 304, 306.
Foreign Trade, salesmanship as a career, $28 \mathrm{ff}$.

"slow siege" the better plan in China, 284.

South African commerce, $341,342$.

suggested papers and periodicals for advertising in foreign lands, $246 \mathrm{ff}$.

three ways of payment for goods sent to foreign lands, 179.

training for, $51 \mathrm{ff}$.

understanding English characteristics important, 369 , ff.

United States selling to Ronmania, 331.

wide vision required, 54.

with British Guiana, imports and exports of, 419 .

with China, $271 \mathrm{ff}$.

with Dutch Guiana, exports of, 419 .

with French Guiana, leading products for export and imports, 419.

with Japan, 259 ff.

with Philippines, 286 ff.

with South America, 402 ff. Foreign Trade Financing Corporation, to assist American foreign commerce, 404.

Foreign trade terms, F.O.B. and other terms explained, 208.

standardized definitions of, $205 \mathrm{ff}$.

Foreign trade training, books and encyclopedias for reading, 58 .

preparing for work in Chile, 103.

Fowler, John F., quoted, $17 \mathrm{ff}$. 
France, advantageous position in Near East, 329.

agricultural and industrial development and markets, 387, 388.

colonizing in Algeria, 338.

importance of French language in commerce, 187. language in Near East, 329.

leading papers and periodicals for advertising, $248 \mathrm{ff}$.

Franklin, Benjamin, quoted, 101.

Freeman, Kenneth J., writes of Eastern culture, 336.

French Guiana, exports and imports of, 419.

Frohman, Charles, business contracts, 426 .

Galsworthy, John, interprets English traits, 372.

General Motors Export Co., training employees, $72 \mathrm{ff}$.

Georgetown University, student training for foreign service, $71 \mathrm{ff}$.

German, commercial importance of German language, 194.

Germany, exports of, 385, 386. trade with Russia, 350, 351.

Goethe, quotations, $28,422$.

Grace Brothers (India) Ltd., customs of doing business in India, 303, 304.

Grace Log, kind of trade articles used, 226.

Grace, W. R. \& Co., evolved from commission house, 21.

offices and trade in Africa, 347.

training employees, $63 \mathrm{ff}$.
Great Britain, in Africa, 333. in India, 296.

shipbuilding progress, 132 .

Greece, American exports to, 326.

amount of trade with U. S., 386.

Guaranty Trust Co., in Latin America, 8.

investment in foreign countries, 9 .

training and welfare work for employees, $75 \mathrm{ff}$.

Haiti, chief exports of, 395.

Haldane, Lord, on relationships between Germany and England, 369, 370.

Hammond, C. E., diseussion of foreign credit departments, $176 \mathrm{ff}$.

Hart, Sir Robert, relation to trade in China, 285.

Harter Act, regarding obligations of a S. S. Co., 139.

Harvard University, courses for foreign training, 85 .

Heck, Lewis, American Consul regarding import and export trade with Near East, 323, 324.

Herodotus, quoted on Egypt, $333,334$.

Hoover, Herbert, quoted, 29.

House organs, difficulties confronting house organs narrated by American firms, 235 .

distribution and budget, 234 . editor and editorial policy, $228 \mathrm{ff}$.

for advertising purposes, 49 . object and policy described by representatives of American business houses, $221 \mathrm{ff}$. 
Houston Post, quoted concerning fruit business in Central America and U. S., $400,401$.

Hughes, Charles E., Secretary of State, statement relative to trade with Russia, 348, 349 .

Hughes, Edward R., explains marine insurance clauses, $140 \mathrm{ff}$.

Idealism, American, seen in trade, $25 \mathrm{ff}$.

Iuporting, things to be kept in mind, 6.

(See Foreign Trade.)

India, American trade with, $295 \mathrm{ff}$.

bibliography of, 120 .

characteristics of Asiatics, $310 \mathrm{ff}$.

description of races and social and business habits, 301.

influence of war on trade, 297.

lack of hurry, 304.

students' desire to learn English, 185 .

Ingersoll, Robert H. \& Bro., language study and training for employees, 86.

Insurance, marine, bibliography relative to, 124 .

International General Electric Co., training employees, $69 \mathrm{ff}$.

Investments, American, in new productive enterprises, 171.

English in America, 362, 363.

opportunities for, in South America, 405 .
Italian, where language is used in commerce, 195.

Italy, markets and resources, 388.

Japan, bibliography for foreign trade study, $118 \mathrm{ff}$. character of products exported from, 268. difficulty of competition with U. S., 267.

imports and exports, 264.

increase of shipbuilding, 132. land holding by Americans, 318.

learning English, 186.

markets with the U.S., $259 \mathrm{ff}$. trade progress in India, 299, 300.

war trade with Belgian Congo, 347.

Jefferson, Thomas, re navigation, $125 \mathrm{ff}$.

Johannesburg, great building progress, 343.

Johnson, Samuel, quoted, 12.

Jowett, master of Baloil, quoted on English traits, 374.

Kahler, Hugh, quoted regarding advertising, 44 .

Kipling, Rudyard, quoted on Africa, 333.

relative to hurry in the East, 304.

concerning team play, 10 .

Kitchener, Lord, in Egypt, 314. Korea, books descriptive of, 119.

Labor, problems of, in Japan, $261 \mathrm{ff}$.

in Philippines, 291.

Lamont, Thomas W., regarding Japan's problem, 260.

Languages, bibliography of 
books in various commercial languages as helps for aequring speaking knowledge, $197 \mathrm{ff}$.

Languages, commercial importance of and advantages of knowing, $185 \mathrm{ff}$.

commereial languages and trade vocabularies, 103. necessity for learning Russian, 358 .

three most important commercial languages, $187 \mathrm{ff}$.

Latin America, cable facilities to, $152 \mathrm{ff}$.

Literature and study courses, $101 \mathrm{ff}$.

Livingston, quoted, 333.

Locke, John, quoted, 46.

Lowell, James Russell, quoted, 221.

quoted concerning industrial work, 290.

Lumber, in Philippines, 7.

Mec'utcheon, George Barr, character of Americans, 26.

MeKinley, President, quoted relative to annexing the Philippines, 292.

Manufactures, American, breaking world's record, $2 \mathrm{ff}$.

Marine Insurance, bibliography relative to, 124 .

deseribed and common insurance clauses explained, $138 \mathrm{ff}$.

Marine Underwriters, 138.

Mears, Elliott S., regarding employment of local salesmen in the Levant, $192 \mathrm{ff}$.

Mediterranean ports, American trade with, 386 .

Merehant Marine, America, $12.5 \mathrm{ff}$.
Mesopotamia, oil fields of, 329 . Mexico, her national wealth, $391,392$.

Mining, American money invested in Mexico, 392.

Missionaries, hindered at times, 318.

paving way for trade in Near East, 321.

point of view of, in Asia, 309.

Mohammedans, in Indian trade, $302,304$.

Murray, Prof. Gilbert of Osford, contrasts mental traits of English and American students, 383.

Napoleon, quoted concerning difficulties, 55 .

National Cash Register Co., field instructions for foreign trade, $98 \mathrm{ff}$.

National City Bank of N. Y., example of procedure in a foreign trade transaction, $181 \mathrm{ff}$.

in Latin America, 8.

number of branches and services rendered abroad, $17 \cdot 2$.

training for banking service in foreign branches, $90 \mathrm{ff}$.

National Foreign Trade Council, information for training, $57 \mathrm{ff}$.

makes standard definitions of foreign trade terms, 205 ff.

Near East, the, American trade in, $321 \mathrm{ff}$.

bibliography for study of foreign trade, 117.

the, Japanese representatives in, 329 . 
Near East, the, oil fields of, 329. work of American committee for relief of, 328 .

Newspapers and periodicals as foreign trade builders, $238 \mathrm{ff}$.

the American press in its relation to Latin American news, $238 \mathrm{ff}$.

Nixon, Lewis, re merchant marine, 128.

Norton, Edward J., consul, on public informatoin, suggestion for business leaders' training for Russia, $357,358$.

outlines work of American Consular service, $252 \mathrm{ff}$.

Okuma, Marquis, statement relative to Japan's progress, 262.

Orient, modernizing herself, 319.

Oxford, Union, miniature English world, 373,374 .

Packard Motor Car Co., training in business practice, 93.

Panama Canal, advantage for Pan-American commerce, 405.

Canal bill, 425.

Pan-Ameriean Union, literature of, 113.

Paraguay, products for export and import, 418.

Pasha Tewfik, dislike of British, 315.

Pennsylvania, University of, $84 \mathrm{ff}$.

Persia, trade of, 332.

trade with U. S., 332.

Peru, leading exports and imports, 416.
Philippines, books descriptive of, $119 \mathrm{ff}$.

friars' lands, 289.

influence of home politics upon, 292.

labor problems, 291.

principal exports of, 288.

trade possibilities and industrial progress of, $286 \mathrm{ff}$. trade schools and education, $289 \mathrm{ff}$.

Plato, quoted, 205.

Porto Rico, products of, 395.

Portugal, foreign trade with U. S., 390.

Portuguese, importance of language and where used in commerce, $191 \mathrm{ff}$.

Quebee, largest producer of wood pulp, 365 .

Raleigh, Sir Walter, re overseas trade, 125.

Railways, in Russia, 353, 354.

Religion, Asiatie, 312, 313.

Christianity in India, 319.

Richardson, H. K.., regarding American business partnerships with Chinese, 282.

Robert College, Engineering School of, 327.

Rochefoucauld, François Due de la, quoted, 185.

Root, Elihu, analyzing South Americans and their trade, 402 .

Roumania, agricultural prosperity and oil fields, 331 .

natural resources, 331.

Ruskin, John, quoted, 53.

Russia, American commerce with, $348 \mathrm{ff}$.

Russia, living conditions and social customs, $357,358$. 
Russia, national wealth and resources, 352, 353.

southern, natural resources and minerals, 331 .

Russian, language of, and reasons for acquirement, $193 \mathrm{ff}$.

Salesmanship, decalogue of a foreign salesman, $39 \mathrm{ff}$. foreign, $28 \mathrm{ff}$.

language requirements of, 192 ff.

San Domingo, imports and exports of, 395 .

Sanger, J. W., trade commissioner, reports of, 110.

Scandinavia, press, dailies and weeklies, 249.

Seamen's Act, need of radical changes in, 134.

Serbia, markets of, 331 .

need of manufactured and finished articles, 331.

Shaw, W. C., quoted, characteristics of successful salesman, 29.

Shedd, Dr., book of, 229 .

Sheep raising in Australia, 368. Shipping, American, 125 ff.

American shipping increasing, 15.

England's preëminence before war, 359.

in principal countries, 132.

Italian flag in Near Eastern waters, 329 .

Japanese, 265.

lack of, to Near Eastern ports, 324, 325 .

losses of, through World War, 131.

maritime leader required, 136 .

Shipping, necessity of, $7 \mathrm{ff}$.

new S. S. lines to South America, 408.
Shipping, principal books relating to, $123 \mathrm{ff}$.

world's merchant steam tonnage, $129 \mathrm{ff}$.

Silver, one of Mexico's principal exports, 392.

Singer Sewing Machine Co., in China, 281.

successes abroad, 16.

Snider, Dr. Guy Edw., selling in foreign markets, 107.

South America, cable communications with, $156 \mathrm{ff}$.

characteristics of people, 410 ff.

comparison export and import business of different republics, $413 \mathrm{ff}$.

foreign leadership in business enterprise, 406.

necessity for investing capital in, 405.

newsipapers and periodicals, $238 \mathrm{ff}$

new steamship lines, 408 .

Panama Canal assisting PanAmerican trade activities, 404.

reciprocal trade necessary, 408.

trade with U. S. in 1920-21, 409.

winning her trade, $402 \mathrm{ff}$.

South American, books, descriptive and industrial, 111.

trade with the U. S. before the war, 16.

Spain, influence upon South America, 406.

manufactures and markets, 389.

Spanish language, in what countries used, requirements for commerce, $188 \mathrm{ff}$. 
Standard Oil Co., foreign trade successes of, 16.

in China, 281.

on training employees, $62 \mathrm{ff}$. Stevenson, Robert L., on Euglish affectation, 373.

Sugar, Cuba, "the world's sugar bowl," $393 \mathrm{ff}$.

Sun Jat Sen, his plan for railways in China, 316.

Syracuse University, classes and instruction for overseas trade, $96 \mathrm{ff}$.

Taft, ex-President, quoted, 1.

Tariff, legislation 1920, 405 .

Telegraphy, radio, used to supplement cable facilities, $146 \mathrm{ff}$.

Tennyson, quoted, 250.

Texas Co., The, training employess, 93.

Timber industry in Russia, 354, 355.

Times, N. Y., quoted relative to North American methods in Sonth America, $411,412$.

Townsend, Meredith, compares Asia with Europe, 308. Training, bibliography in training for foreign commerce, $111 \mathrm{ff}$.

business firms training for foreign commerce, $61 \mathrm{ft}$. for foreign commerce, $51 \mathrm{ff}$. preparation needed for traders with Russia, 356, 357.

questions necesisary for foreign traders to answer, 56.

subjects for outline courses, 106 ff.

vocational study, helpfulness of, $60 \mathrm{ff}$.
Trarel, Englishmen and Americans contrasted, 373,376 .

Travelers, campaign for, to South America, 241.

Turkey, American colleges in, 322.

commerce with U. S., 386.

condition of Turkish money, 330.

trade possibilities with U. S., 327.

Turkish official characterized, 309.

United Fruit Co., developing Central America, 379 ff.

United Kingdom of Great Britain, exports and imports with U. S., 361, 362.

markets with, $359 \mathrm{ff}$.

United States, commerce, 13 ff. natural resources, coal, cotton, etc., 52.

United States Shipping Board, 129.

United States Steel Corporation, foreign service classes for training, $85 \mathrm{ff}$.

University of Virginia, preparing business men for Latin American service, $95 \mathrm{ff}$.

Uruguay, cable communications with, 158.

leading exports and imports of, 418 .

Vedder, Geo. C., qualifications of export manufacturer, $24 \mathrm{ff}$.

Veuezuela, chief imports and exports, 417.

Wars, influence on trade, $1 \mathrm{ff}$. Waterman, L. E., Co., training employees, 87. 
Webb Bill, along lines of need, 10.

help to foreign commerce, 403.

Webster, Daniel, re commerce on the sca, 125.

West Indies, $391 \mathrm{ff}$.

books descriptive of, $121 \mathrm{ff}$. Westinghouse Electric and Mfg. Co., edueational and technical training for foreign commerce, $87 \mathrm{ff}$.

Wharton School, preparing students for foreign trade service, $84 \mathrm{ff}$.
Wheat, Russia as Europe's granary, 355.

William and Mary, College of, subjects and books used in training students for foreign trade, 71.

Wood pulp, Quebec, largest producer of, 365 .

Wool, the important product in Australia, 368.

World responsibility, 427.

Wyman, Walter F., quoted relative to successful letter writing, $47 \mathrm{ff}$. 

UNIVERSITY OF CALIFORNIA LIBRARY

Los Angeles

This book is DUE on the last date stamped below.

$\mathrm{rm} \mathrm{L}, 9-25 m \cdot 8, ' 46(9852) 444$ 
UC SOUTHERN REGIONAL LIBRARY FACILITY

AA 0010082980 
